\title{
Aprendizagem e comportamento humano
}

\author{
Tânia Gracy Martins do Valle \\ Ana Cláudia Bortolozzi Maia \\ (orgs.)
}

VALLE, TGM., and MAIA, ACB., orgs. Aprendizagem e comportamento humano [online]. São Paulo: Editora UNESP; São Paulo: Cultura Acadêmica, 2010. 255 p. ISBN 978-85-7983-122-5. Available from SciELO Books $\langle$ http://books.scielo.org $>$.

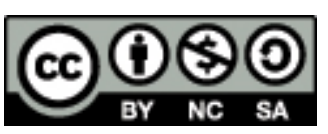

All the contents of this chapter, except where otherwise noted, is licensed under a Creative Commons Attribution-Non Commercial-ShareAlike 3.0 Unported.

Todo o conteúdo deste capítulo, exceto quando houver ressalva, é publicado sob a licença Creative Commons Atribuição Uso Não Comercial - Partilha nos Mesmos Termos 3.0 Não adaptada.

Todo el contenido de este capítulo, excepto donde se indique lo contrario, está bajo licencia de la licencia Creative Commons Reconocimento-NoComercial-CompartirIgual 3.0 Unported. 


\section{APRENDIZAGEM E COMPORTAMENTO HUMANO}

TÂNIA GRACY MARTINS DO VALLE ANA CLÁUDIA BORTOLOZZI MAIA (ORGS.) 


\section{APRENDIZAGEM E COMPORTAMENTO HUMANO}


CONSELHO EDITORIAL ACADÊMICO

Responsável pela publicação desta obra

Alessandra Turini Bolsoni Silva

Jair Lopes Júnior

Lúcia Pereira Leite

Olga Maria Piazentin Rolim Rodrigues 
TÂNIA GRACY MARTINS DOVALLE ANA CLÁUDIA BORTOLOZZI MAIA (ORGS.)

\section{APRENDIZAGEM E COMPORTAMENTO HUMANO}

CULTURA $\frac{\text { ACADÊMICA }}{\mathcal{E} \text { diton } a}$ 
(C) 2010 Editora UNESP

\section{Cultura Acadêmica}

Praça da Sé, 108

01001-900 - São Paulo - SP

Tel.: (0xx11) 3242-7171

Fax: (0xx11) 3242-7172

www.editoraunesp.com.br

feu@editora.unesp.br

CIP - Brasil. Catalogação na fonte

Sindicato Nacional dos Editores de Livros, RJ

A661

Aprendizagem e comportamento humano / Tânia Gracy Martins do Valle, Ana Cláudia Bortolozzi Maia (orgs.). - São Paulo : Cultura Acadêmica, 2010.

Inclui bibliografia

ISBN 978-85-7983-122-5

1. Psicologia da aprendizagem. 2. Psicologia do desenvolvimento. 3. Habilidades sociais. 4. Inclusão escolar. 5. Interação social. 6. Comportamento humano - Aspectos psicológicos. I. Valle, Tânia Gracy Martins do. II. Maia, Ana Cláudia Bortolozzi.

$11-0131$.

CDD: 370.1523

CDU: 37.015 .3

Este livro é publicado pelo Programa de Publicações Digitais da Pró-Reitoria de Pós-Graduação da Universidade Estadual Paulista "Júlio de Mesquita Filho" (UNESP)

Editora afiliada:
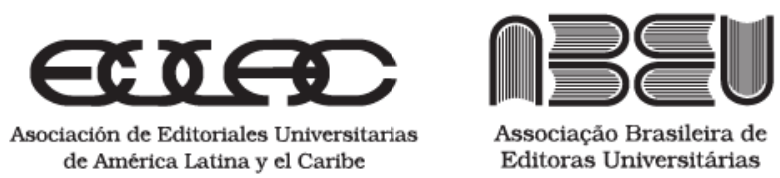
Agradecemos aos professores do Programa de PósGraduação em Psicologia do Desenvolvimento e Aprendizagem da Faculdade de Ciências da Unesp, campus de Bauru, que leram e contribuíram com sugestões para o aperfeiçoamento deste livro.

Também agradecemos, em especial, a colaboração preciosa de Gethiely Silva Gasparini, secretária do referido programa, na preparação dos materiais iniciais e na organização dos documentos necessários para a conclusão desta obra. 



\section{SUMÁRIO}

Apresentação 9

\section{Parte I - Inclusão escolar e diversidade na escola}

1 Flexibilização e adaptação curricular no processo de inclusão escolar 17

Katia Abreu Fonseca, Vera Lúcia Messias Fialho Capellini e Jair Lopes Junior

2 Recursos utilizados por professoras para se comunicarem com alunos com síndrome de Asperger em sala de aula comum 35

Maria Cláudia Brito, Kester Carrara e Débora Deliberato

3 Volta às aulas aos sessenta anos: perfil dos alunos em uma universidade aberta à terceira idade $\quad 55$ Lauren Mariana Mennocchi e Lúcia Pereira Leite

4 Avaliação e intervenção com crianças em condição de sobrepeso e obesidade 73 Lucinéia Crepaldi de Mello e Sandro Caramaschi

5 Análise da regulamentação sobre educação inclusiva no estado de São Paulo 93

Marileide Antunes de Oliveira e Lúcia Pereira Leite 
6 A influência de problemas de comportamento sobre o desempenho escolar 111 Marta Regina Gonçalves Correia-Zanini e Olga Maria Piazentin Rolim Rodrigues

\section{Parte II - Aplicações da Análise do Comportamento na educação}

7 Análise experimental das relações entre o ouvir e o falar em deficientes auditivos implantados cocleares 133 Fernanda Luz Anastacio Pessan, Fabiana Cristina de Souza, Bruna Mares Terra, Luiza Quadros Kutlesa Catunda, Ana Claudia Moreira Almeida Verdu e Maria Cecília Bevilacqua

8 Estratégias metodológicas no estudo da atuação profissional do treinador esportivo 153 Jair Lopes Junior e Cintia Allyson Jensen

9 Reconstrução conceitual do prestar atenção na Análise do Comportamento 177 Bruno Angelo Strapasson e Kester Carrara.

\section{Parte III - Habilidades sociais e relações educativas}

10 Investigando as habilidades sociais de pré-escolares com problemas de comportamento 197 Vanessa Barbosa Romera e Alessandra Turini Bolsoni-Silva

11 Promovendo habilidades sociais educativas parentais: caracterizando a atuação do terapeuta 215 Fabiane Ferraz Silveira, Alessandra Turini Bolsoni-Silva e Sonia Beatriz Meyer

12 A interação entre pais e filhos adolescentes sob a ótica da análise aplicada do comportamento 233 Gabriela Mello Sabbag e Alessandra Turini Bolsoni-Silva 


\section{ApresentaÇÃo}

Ana Cláudia Bortolozzi Maia

O livro Aprendizagem e comportamento humano reúne vários capítulos referentes aos trabalhos de pesquisa teórica e prática dos professores junto a discentes e pesquisadores de outras instituições do Programa de Pós-Graduação em Psicologia do Desenvolvimento Humano e Aprendizagem. Os textos reunidos neste livro contemplam o tema da aprendizagem e do comportamento, vinculados às propostas educativas no cenário da inclusão social e escolar. Os capítulos serão apresentados reunidos por temática: "Inclusão escolar e diversidade na escola", "Aplicações da análise do comportamento na educação" e "Habilidades sociais e relações educativas".

Na primeira parte, "Inclusão escolar e diversidade na escola", encontram-se cinco capítulos.

Katia Abreu Fonseca, Vera Lúcia Messias Fialho Capellini e Jair Lopes Junior, no capítulo "Flexibilização e adaptação curricular no processo de inclusão escolar”, apresentam um estudo teórico sobre o processo de inclusão escolar no Brasil, refletindo sobre as discussões necessárias para se garantir o respeito à diversidade e à heterogeneidade dos alunos na sala de aula, aliado ao desenvolvimento pleno desses alunos, tais como a formação dos professores, a adaptação curricular com estratégias de adequação às necessidades individuais dos alunos e a flexibilização curricular. 
Maria Cláudia Brito, Kester Carrara e Débora Deliberato, no capítulo "Recursos utilizados por professoras para se comunicarem com alunos com síndrome de Asperger em sala de aula comum”, relatam a pesquisa que avaliou, por meio da análise de conteúdo de filmagens, como professores de ensino comum em escolas públicas utilizavam recursos para se comunicarem com alunos que apresentam a síndrome de Asperger. Os autores descrevem as quatro categorias de recursos analisadas, que foram: objeto concreto, gesto, escrita e verbalização. Os resultados encontrados são importantes para contribuir com ações relativas à formação de professores para o planejamento e aplicação de recursos e estratégias de ensino que visem promover a efetiva educação inclusiva de crianças com distúrbios do espectro autístico.

Lauren Mariana Mennocchi e Lúcia Pereira Leite, em "Volta às aulas aos sessenta anos: perfil dos alunos de uma universidade aberta à terceira idade", apresentam uma pesquisa teórica com reflexões interessantes sobre o envelhecimento e o desenvolvimento humano a partir do referencial teórico da Psicologia Histórico-Cultural. As autoras discorrem sobre o processo de aprendizagem na velhice, enfatizando as Universidades para a Terceira Idade (Unatis), mais especificamente os dados de uma Unati vinculada a uma instituição de Ensino Superior privada localizada em uma cidade do oeste paulista, apresentando: o histórico e os objetivos do programa, a caracterização dos alunos que a procuram e a frequentam e as expectativas desses alunos.

Lucinéia Crepaldi de Mello e Sandro Caramaschi, no texto "Avaliação e intervenção com crianças em condição de sobrepeso e obesidade", relatam uma pesquisa sobre bullying e obesidade, realizada para avaliar crianças em condições de sobrepeso e obesidade e para intervir junto a estas. Os autores apresentam uma discussão sobre a obesidade de crianças e situações de discriminação e violência que algumas sofrem por parte dos colegas. A partir disso, apresentam um programa de intervenção com várias sessões em que são refletidas, junto às crianças, questões como a autoavaliação referente à imagem corporal, a expressão de sentimentos, os hábitos ali- 
mentares saudáveis e as habilidades sociais para enfrentarem relações interpessoais.

Marileide Antunes de Oliveira e Lúcia Pereira Leite, no capítulo "Análise da regulamentação sobre educação inclusiva no estado de São Paulo", apresentam um texto teórico sobre as normativas e prescrições legais que regulamentam o processo de educação inclusiva no estado de São Paulo. As autoras introduzem os princípios da inclusão escolar e discorrem sobre as diretrizes da Educação Especial no País, analisando os principais enunciados da Resolução SE $n^{\circ} 8 / 2006$ à luz dos pressupostos do ensino inclusivo, considerando, então, os processos de ensino e aprendizagem, o plano de trabalho didático-pedagógico, a avaliação educacional e a prática pedagógica de professores.

Marta Regina Gonçalves Correia-Zanini e Olga Maria Piazentin Rolim Rodrigues, no capítulo "A influência de problemas de comportamento sobre o desempenho escolar", relatam uma pesquisa que descreveu e avaliou o desempenho acadêmico de alunos indicados por seus professores como tendo problemas de comportamento e de alunos sorteados, antes e depois de um processo de intervenção sobre manejo de problema de comportamento. As autoras comentam sobre o conceito e as implicações de baixo rendimento acadêmico escolar e sua relação com problemas de comportamento. Além disso, também relacionam as expectativas do professor sobre o desempenho de seus alunos, lembrando que os problemas de comportamento, os problemas emocionais, o baixo rendimento escolar e a interação entre os professores e os alunos são questões interrelacionadas que precisam ser investigadas visando alterar esse quadro disfuncional que prejudica os objetivos educacionais.

Na segunda parte do livro, "Aplicações da Análise do Comportamento na educação", encontram-se outros três capítulos.

Fernanda Luz Anastacio Pessan, Fabiana Cristina de Souza, Bruna Mares Terra, Luiza Quadros Kutlesa Catunda, Ana Claudia Moreira Almeida Verdu e Maria Cecília Bevilacqua, no texto "Análise experimental das relações entre o ouvir e o falar em deficientes auditivos implantados cocleares", descrevem operantes verbais e 
apresentam os aspectos gerais do paradigma das relações de equivalência, bem como sua aplicação na investigação das condições necessárias e suficientes para a emergência de modos ativos e receptivos de linguagem em deficientes auditivos, a partir de pressupostos teóricos da Análise do Comportamento. Os autores discorrem sobre linguagem e comportamento verbal, deficiência auditiva e implante coclear e, ainda, apresentam relatos de pesquisas concluídas e em andamento sobre essa interessante temática.

Jair Lopes Junior e Cintia Allyson Jensen, no texto "Estratégias metodológicas no estudo da atuação profissional do treinador esportivo", relatam uma pesquisa fundamentada nos pressupostos teóricos da Análise do Comportamento com a temática da Psicologia do Esporte. Os autores argumentam sobre as características dos repertórios comportamentais na instrução de um treinador esportivo em situação de competição e contribuem com as questões da pesquisa apresentada com reflexões sobre os processos de ensino e de aprendizagem na área do esporte.

Bruno Angelo Strapasson e Kester Carrara, no capítulo "Reconstrução conceitual do prestar atenção na Análise do Comportamento", apresentam um texto, a partir dos pressupostos teóricos na Análise do Comportamento, sobre o "prestar atenção", primeiramente refletindo sobre os diversos significados que podem ser atribuídos ao uso desse conceito que não é consensual entre os analistas do comportamento. Os autores examinam o "prestar atenção" como relação de controle de estímulos, como resposta de observação e como comportamento precorrente encoberto, e se utilizam de uma reconstrução conceitual para avaliar quais proposições teóricas sobre o "prestar atenção" na Análise do Comportamento são mais coerentes com os pressupostos filosóficos do Behaviorismo Radical.

Finalmente, na terceira parte do livro, "Habilidades sociais e relações educativas", encontram-se três capítulos.

Vanessa Barbosa Romera e Alessandra Turini Bolsoni-Silva, no texto "Investigando as habilidades sociais de pré-escolares com problemas de comportamento", apresentam uma pesquisa sobre as habilidades sociais de crianças pré-escolares identificadas pelos seus 
professores como tendo problemas de comportamento. As autoras descrevem as habilidades sociais e os problemas de comportamento no período da infância e apresentam a avaliação das habilidades sociais infantis, considerando os dados das crianças, dos professores e de seus familiares, demonstrando uma abrangente investigação.

Fabiane Ferraz Silveira, Alessandra Turini Bolsoni-Silva e Sonia Beatriz Meyer, no texto "Promovendo habilidades sociais educativas parentais: caracterizando a atuação do terapeuta”, relatam uma pesquisa focalizada no papel do terapeuta como agente efetivo em programas de intervenção que tenham por objetivo melhorar a interação entre pais e filhos. As autoras discutem sobre a influência dos fundamentos teórico-práticos adotados, aspectos do programa de intervenção e comportamentos do cliente como determinantes para o comportamento do terapeuta.

Gabriela Mello Sabbag e Alessandra Turini Bolsoni-Silva, no texto "A interação entre pais e filhos adolescentes sob a ótica da Análise Aplicada do Comportamento", apresentam uma discussão teórica, a partir dos pressupostos da Análise do Comportamento, sobre a interação entre pais e filhos no período da adolescência. As autoras descrevem as relações comportamentais entre pais e filhos avaliadas pela análise funcional e, para tal, sustentam-se na proposta de Habilidades Sociais Educativas Parentais.

Espero que o leitor possa aprofundar o conhecimento sobre a temática da aprendizagem e do comportamento considerando as diferentes pesquisas e reflexões teóricas apresentadas neste livro, sustentadas pelas contribuições dos estudos das Habilidades Sociais, dos pressuspostos teóricos da Psicologia Histórico-Cultural e da Análise do Comportamento. A inclusão social e escolar, que é uma prerrogativa atual e importante no cenário mundial, tem implicações que repercutem no âmbito da escola e também nas relações familiares e sociais. Por isso, os trabalhos aqui descritos, que espelham, sobretudo, o olhar da Psicologia, utilizam abordagens tanto pedagógicas como clínicas e o livro pode ser um material de consulta importante para pesquisadores e interessados no tema. 



\title{
Parte I
}

\author{
INCLUSÃO ESCOLAR E \\ DIVERSIDADE NA ESCOLA
}





\title{
1
FLEXIBILIZAÇÃO E ADAPTAÇÃO CURRICULAR NO PROCESSO DE INCLUSÃO ESCOLAR
}

\author{
Katia Abreu Fonseca ${ }^{1}$ \\ Vera Lúcia Messias Fialho Capellini ${ }^{2}$ \\ Jair Lopes Junior ${ }^{3}$
}

\section{Introdução}

Admite-se, com expressivo consenso, a natureza processual da inclusão escolar. Contudo, mesmo considerando-se a precedência com a qual o tema foi objeto de discussão em relação à Declaração de Salamanca, tanto quanto a existência dos dispositivos legais previstos na Constituição Federal, de 1988, a explicitação dos paradigmas que definem a inclusão escolar ainda se apresenta como etapa necessária para qualquer proposta de investigação e de reflexão sobre dimensões de tal processo.

Assim, a inclusão escolar consiste no processo de adequação da sociedade às necessidades de seus participantes, para que eles, uma vez incluídos, possam desenvolver-se e exercer plenamente sua cidadania. Segundo Stainback \& Stainback (1990), a inclusão é uma consciência de comunidade, uma aceitação das diferenças e uma corresponsabilização para obviar às necessidades de outros.

1 Programa de Pós-Graduação em Psicologia do Desenvolvimento e da Aprendizagem da Faculdade de Ciências da Unesp - Bauru.

2 Idem.

3 Idem. 
Ao discutirmos o processo de inclusão, devemos compreender que este está vinculado a todos os âmbitos da sociedade, tais como educação, esporte, lazer, religião, família etc., e a todos os participantes da sociedade. Infelizmente, por muito tempo, o conceito de inclusão foi entendido erroneamente, com a ideia de incluir apenas as pessoas com deficiência em um determinado grupo social e/ou educacional. Tal equívoco salientou a necessidade e a urgência de um retorno aos fundamentos conceituais do processo de inclusão, com ênfase reiterada no posicionamento ao qual conceito se destina, a saber, que é a inclusão de todos os cidadãos em todos os grupos sociais, independente de sua condição física, intelectual, sensorial, cultural, social ou econômica.

É evidente que por uma necessidade de oferecer igualdade de oportunidades a todos os cidadãos, principalmente àqueles que estão à margem da sociedade, como muitos negros, muitas pessoas com deficiência, muitos pobres, dentre os distintos exemplos de minorias, é que foram conduzidas discussões sobre de que forma a sociedade poderia se adequar para diminuir a distância entre os participantes de uma mesma cultura com distintas oportunidades. A Educação Especial, enquanto área de conhecimento, ostenta um histórico de mobilização permanente de esforços em diferentes dimensões da atuação profissional e acadêmica de seus membros para produzir mudanças dos paradigmas acerca da inclusão educacional da pessoa com deficiência, pois foi com a aceitação dos direitos das pessoas desse grupo que a sociedade iniciou ações para diminuir preconceitos e aumentar a visibilidade da capacidade das pessoas com deficiência.

Uma das primeiras instituições sociais a redefinir seus objetivos para atender essa "nova" demanda social foi a escola. Na condição de instituição, a escola, sob o imperativo da lei e em cumprimento aos dispositivos legais, matriculou alunos com deficiências e tornou-se responsável pelo provimento de condições para o desenvolvimento acadêmico efetivo a todos os alunos.

Nesse contexto, a inclusão causa uma mudança de perspectiva educacional, pois além de atender as dificuldades dos alunos, envol- 
ve a todos: pais, direção, alunos e professores. Portanto, a inclusão educacional, enquanto processo, constitui-se em condição ou em fator indutor e imprescindível para a construção de um novo tipo de sociedade delineando pequenas e grandes transformações, nos diversos ambientes físicos (espaços internos e externos), nos recursos materiais (equipamentos, aparelhos e utensílios, mobiliários e meios de transporte) e nas concepções de pessoas envolvidas direta e indiretamente com a educação, sendo que, quiçá, as maiores resistências às necessárias mudanças residam justamente em tais concepções.

No presente, após mais de uma década de discussões relacionadas aos documentos sobre a temática, tais como a Declaração de Salamanca, de 1994, a Lei de Diretrizes e Bases da Educação Básica, de 1996, as Diretrizes Nacionais para a Educação Especial na Educação Básica, de 2001, dentre outros, não se mostra incomum a verificação, nas escolas, de posicionamentos negativos quanto à presença de alunos com deficiência, principalmente com relação àqueles que necessitam de apoio generalizado, visto que tal presença requer, de modo praticamente contínuo, recursos e estratégias muito específicos, intensos e geralmente complexos para ampliar a participação na sociedade e aumentar o desenvolvimento pessoal de tais alunos (Tamarit, 2004, p.259).

Apresentam-se, nesses casos, como prática discursiva frequente, argumentos que ressaltam a falta de preparo dos profissionais (especialmente a dos professores) e a falta de estrutura física e curricular. Em um determinado momento, existiu a aceitação camuflada, por meio da qual a escola matriculava o aluno com deficiência, mas se isentava do ensino desse aluno, assumindo uma postura apenas de socialização, contrariando os objetivos reais da escolarização, a saber, o de ensinar os alunos no aspecto acadêmico, caracterizando assim o modelo de integração ${ }^{4}$ e não o de inclusão.

4 Entendido como um fenômeno complexo de colocação do aluno com deficiência na sala regular, sem qualquer suporte e/ou recursos que oportunizem a aprendizagem. 
Atualmente, com a vivência de um período de negação da participação do aluno com deficiência na sala regular possivelmente ainda não superado das escolas, a questão de fronteira a desafiar pesquisadores e profissionais envolvidos direta e indiretamente com a educação permanece no delineamento de modelos e na execução de procedimentos de interação entre agentes e alunos nas escolas e dentro da sala de aula, uma vez que os alunos com deficiência estão matriculados e frequentando as escolas de ensino regular. $\mathrm{O}$ atendimento da legislação segundo a qual toda criança tem direito à educação, tendo seus interesses e características individuais respeitadas, indubitavelmente salienta a necessidade de aquisição e de desenvolvimento de competências e de habilidades específicas e, provavelmente, não expostas nos processos de formação acadêmica de tais profissionais. O sistema educacional deve atender a vasta diversidade de alunos, "satisfazendo" suas necessidades educacionais apresentadas no decorrer do processo de aprendizagem, pois

promover a Educação para Todos, analisando as mudanças fundamentais de políticas necessárias para favorecer o enfoque da educação integradora, capacitando realmente as escolas para atender todas as crianças, sobretudo as que têm necessidades especiais. (Brasil, Declaração de Salamanca, 1994, p.5)

O professor deve desenvolver a prática da reflexão (ação/reflexão/ação), repensar sua prática e utilizar novas estratégias que oportunizem o aprendizado de todos os alunos, respeitando assim o estilo de aprendizagem de cada aluno, não gerando atitudes preconceituosas e não rotulando seus alunos com dificuldade de aprendizagem como "diferentes" ou especiais, pois a inclusão não prescreve apenas atendimentos individualizados para os alunos com deficiência, mas a eliminação dos obstáculos, para que todos aprendam e assim tenham acesso ao currículo comum. "Não se pode esperar que um conjunto único de objetivos padronizados possa satisfazer a capacidade de aprendizagem singular de cada aluno" (Stainback et al., 2003, p.241). Entretanto, as diferentes opiniões sobre o assunto in- 
clusão (socialização x aprendizagem) geram discussões e questionamentos. Essas profundas reflexões tornaram possível uma nova ideologia filosófica sobre a escola inclusiva, como conceitua Marchesi (2004, p.15):

O conceito de escolas inclusivas supõe uma maneira mais radical de entender a resposta educativa à diversidade dos alunos e baseia-se fundamentalmente na defesa de seus direitos à integração e na necessidade de promover uma profunda reforma das escolas, que se torne possível uma educação de qualidade para todos, sem nenhum tipo de exclusão.

As reflexões sobre a definição e o alcance do processo de inclusão escolar fomentaram discussões sobre reformas que se mostram urgentes para garantir o respeito à diversidade e à heterogeneidade dos discentes em sala de aula, mas garantindo, de modo inconteste, as condições para o desenvolvimento global de tal contingente. A diversidade e a heterogeneidade mostram-se refratárias ao modelo de educação fundamentado no pressuposto de que práticas de ensino comuns e uniformes garantiriam aprendizagens homogêneas mesmo diante de alunos com distintas características de desenvolvimento biológico, histórico e cultural. Em oposição, paradigmas contemporâneos ressaltam a relevância de intervenções amparadas no reconhecimento da singularidade dos alunos em seus processos de aprendizagem, sendo que alguns com deficiência requerem intervenções diferentes daquelas costumeiras para a maioria. Assim, as experiências e os desafios enfrentados na sala de aula impõem ao professor a necessidade e a oportunidade de construir um repertório cada vez maior de estratégias e de ajustes para potencializar a aprendizagem.

Criar atividades que abranjam as diferentes capacidade dos alunos e que, ao mesmo tempo, mantenham um contexto de grupo com os membros da turma lidando com objetivos diferentes em momentos diferentes, pode ajudar a superar esse problema potencial. (Stainback et al., 2003, p.241) 
Ao receber um aluno com deficiência (independente da deficiência), o professor assume a responsabilidade de conduzi-lo à construção do conhecimento e deverá prestar contas ao sistema e aos demais alunos por meio da evolução do desempenho desse aluno com deficiência. Para que essa evolução acadêmica (evolução na aprendizagem) ocorra, torna-se necessário que seja feito algum tipo de mudança na rotina da qual todos os alunos participam.

É inegável que as deficiências exigem do sistema escolar respostas que vão além da formação de cultura. Um cego requer, para acessar o currículo, adaptações materiais. Por sua vez, um aluno com deficiência física pode necessitar de tecnologia assistida para também acessar o currículo. No entanto, uma pessoa com deficiência intelectual no ambiente escolar, quando com comprometimento físico e/ou cognitivo significativo, necessita de um currículo adaptado. Nessa situação, simplesmente considerar que existem diferenças, ignorando as necessidades, é como afirmar que a deficiência intelectual deixou de existir. Parece-nos, portanto, que só proporcionamos a igualdade de oportunidades quando tratamos tais evidências diferentemente.

Historicamente, temos modelos de outros países para tentar suprir essa necessidade de aprendizagem dos alunos com deficiência. Porém, tais modelos precisam ser minuciosamente estudados e discutidos, com o intuito de evitar a ocorrência de distorções nos conceitos aplicados à aprendizagem dos alunos.

Segundo Marques (1998, p.23), Portugal utiliza a seguinte definição para adaptação curricular:

As adaptações curriculares constituirão a construção das vias de acesso ao currículo, apontadas por Vygotsky como um meio de construção de caminhos alternativos que permitirão ao aluno ascender aos conhecimentos escolares. As adaptações curriculares podem desenvolver-se a vários níveis que vão desde o poder Central, ao local, ao do Projecto Educativo de Escola, às programações de aulas e necessidades individuais de cada aluno. 
Este país entende adaptação curricular como estratégias de adequação às necessidades individuais dos alunos e a define como " $\mathrm{O}$ conjunto de modificações que se realizam nos objetivos, conteúdos, critérios e procedimentos de avaliação, atividades e metodologia para atender as diferenças individuais dos alunos" (Ruiz \& Pereja, 2002, p.154).

Ao final da década de 1990, o governo brasileiro publicou os Parâmetros Curriculares Nacionais/adaptações curriculares: estratégias para a educação de alunos com necessidades educacionais especiais, com base no documento of icial da Espanha Adaptaciones curriculares, elaborado pelo Ministério da Educação e Ciência daquele país no ano de 1992 com o objetivo de subsidiar a prática docente nos aspectos que envolvem a aprendizagem de todos os alunos, considerando a diversidade existente na sala de aula comum, indicando a necessidade de medidas de flexibilização e dinamização para atender a todos os alunos, sobretudo aos alunos com deficiência, definindo adaptação curricular como

possibilidades educacionais de atuar frente às dificuldades de aprendizagem dos alunos. Pressupõem que se realize a adaptação do currículo regular, quando necessário, para torná-lo apropriado às peculiaridades dos alunos com necessidades especiais. Não um novo currículo, mas um currículo dinâmico, alterável, passível de ampliação, para que atenda realmente a todos os educandos. Nessas circunstâncias, as adaptações curriculares implicam a planificação pedagógica e ações docentes fundamentadas em critérios que definem o que o aluno deve aprender; como e quando aprender; que formas de organização do ensino são mais eficientes para o processo de aprendizagem; como e quando avaliar o aluno. (Brasil, p.33)

Após essa publicação, o sistema educacional mostrou-se, em âmbito documental, amparado no que diz respeito ao atendimento aos alunos com deficiência na sala de aula comum e uma corrida às adaptações curriculares foi iniciada. Contudo, por falta de esclarecimentos, algumas situações se estabeleceram, como a substituição total do currículo comum por um plano individualizado de ensino (PIE), no 
qual era especificado o que o aluno com deficiência deveria aprender na escola durante aquele ano. Esse documento permanecia válido até que o aluno atingisse todos os objetivos a ele propostos, independente do tempo que isso levaria. Desta forma, a instituição deixou de considerar que o aluno é quem teria de se adaptar à escola, e a escola começou a se adaptar para receber esses alunos.

Majón (1997) definiu adaptações curriculares como sendo

antes de tudo, um procedimento de ajuste paulatino da resposta educativa, que poderá desembocar, ou não, conforme o caso, num programa individual [...] uma estratégia de planejamento e de atuação docente, e nesse sentido, de um processo de tratar de responder às necessidades de aprendizagem de cada aluno.

Por questões de adequação às nomenclaturas, surge então o conceito de flexibilização curricular, que se vincula ao conceito de maleabilidade, do que pode se modificar, flexionar-se, destituindo a tradicional ideia de rigidez. Desta forma, Beyer (2006, p.76), sobre flexibilização curricular, considera que:

O desafio é construir e pôr em prática no ambiente escolar uma pedagogia que consiga ser comum e válida para todos os alunos da classe escolar, porém capaz de atender os alunos cujas situações pessoais e características de aprendizagem requeiram uma pedagogia diferenciada. Tudo isto sem demarcações, preconceitos ou atitudes nutridoras dos indesejados estigmas.

Sendo assim, o currículo deveria ser flexível a todos os alunos e não necessariamente modificado. Entretanto, por algum tempo, esse conceito foi entendido como sinônimo de adaptação. Assim, o currículo continuou sendo modificado, utilizando o PIE como base curricular aos alunos com deficiência. Mudou-se a denominação, mas foram mantidos posicionamentos que priorizavam mudanças estruturais em conteúdos curriculares que prescindiam de alterações devidamente fundamentadas em práticas de ensino e de avaliação. 
É nessa perspectiva que este texto tem o desafio de apresentar e discutir a distinção e a aplicabilidade dos conceitos de adaptação e de flexibilização. Discutiremos aspectos que garantem a flexibilização para todos (com ou sem deficiência) e a adaptação para alguns (que necessitam de apoio generalizado), preservando, de modo prioritário, o objetivo fundamental de ensinar da instituição escola.

A colaboração do profissional da Educação Especial é de suma importância, para a realização da flexibilização curricular necessária para o aluno e/ou a classe, quando pensamos no acesso ao currículo pelos alunos com deficiência, pois a realização dessa flexibilizaçãoéo caminho para o atendimento às necessidades específicas de aprendizagem dos alunos. No entanto, identificar essas "necessidades" requer que os sistemas educacionais modifiquem não apenas suas atitudes e expectativas em relação a esses alunos, mas que se organizem para construir uma escola para todos que, de modo efetivo e fundamentado em evidências, dê conta dessas especificidades.

Capellini (2004, p.60) enfatiza que a

Educação Especial deve ser aliada na pesquisa e no desenvolvimento nas novas formas de ensinar, adequadas às heterogeneidades dos aprendizes e compatíveis com os ideais democráticos, na função de orientação, supervisão e acompanhamento das condições educacionais apropriadas, num interjogo entre o real e o necessário.

O desenvolvimento de ações flexíveis deve visar o acesso ao currículo. Com o propósito de que este seja desenvolvido de maneira efetiva em sala de aula, atendendo às necessidades individuais de todos os alunos, as ações flexíveis devem abranger, em termos de alcance, três níveis: o projeto pedagógico, o currículo desenvolvido na sala de aula e o nível individual (Brasil, 1998).

O primeiro nível deve focalizar, sobretudo, a organização escolar e os serviços de apoio, propiciando condições estruturais que possam ocorrer nos níveis subsequentes, a saber, na sala de aula e no aluno individualmente. O segundo nível faz referência, principalmente, à programação das atividades elaboradas para sala de aula. 
E, por fim, o terceiro nível abrange as atividades de acesso ao currículo que focalizam a atuação do professor na avaliação e no atendimento a cada aluno.

O currículo é construído a partir do projeto político pedagógico da escola, sendo definido por Coll (1996, p.45) como instância

[...] que preside as atividades educativas escolares, define suas intenções e proporciona guias de ação adequadas e úteis para os professores que são diretamente responsáveis por sua execução. Para isso, o currículo proporciona informações concretas sobre o que ensinar, quando ensinar, como ensinar e como e quando avaliar.

O currículo viabiliza sua operacionalização orientando propostas de atividades educativas e as maneiras de sua execução, definindo os fins para a especificidade de cada aluno, inclusive dando subsídios para a identificação e avaliação das necessidades educacionais dos alunos, podendo contribuir com a determinação do apoio necessário ao aluno em momentos (ciclos, fases, séries) específicos da escolarização deste. Deve ser apresentado de forma organizada, objetivando caminhos a serem seguidos e orientando as ações docentes nos diferentes níveis de ensino, o que favorece a aprendizagem de todos os alunos.

A flexibilização não pode ser entendida como uma mera modificação ou acréscimo de atividades complementares na estrutura curricular. Ela exige que as mudanças na estrutura do currículo e na prática pedagógica estejam em consonância com os princípios e com as diretrizes do Projeto Político Pedagógico da escola, na perspectiva de um ensino de qualidade para todos os alunos.

Acerca das adequações do Projeto Político Pedagógico para atender à diversidade, Beyer (2006, p.75) contribui afirmando que:

O projeto político pedagógico inclusivo [...] objetiva não produzir uma categorização "alunos com e sem deficiência, com e sem distúrbios, com e sem necessidades especiais" (a adjetivação é ampla e flutuante, conforme os vários diagnósticos possíveis). Para tal abordagem 
educacional não há dois grupos de alunos, porém apenas crianças e adolescentes que compõem a comunidade escolar e que apresentam necessidades variadas.

Uma adaptação de acesso ao currículo deve ser flexível, priorizando as especificidades da diversidade, bem como o entendimento do processo de aprendizagem das crianças, considerando as possibilidades e dificuldades de cada uma.

Os componentes curriculares e seus conteúdos precisam ser mantidos, porém flexibilizados. Nesta linha de argumentação, Zanata (2004) advoga que as modificações deveriam incidir mais na prática pedagógica e menos no currículo propriamente dito.

Sendo assim, as mudanças ocorrem na forma de priorização de objetivos, de conteúdos e de modalidades de avaliação, de apresentação das atividades, na visualização dos conceitos a serem ensinados dentro de uma proposta de educar na diversidade, na mudança na temporalidade dos objetivos, dos conteúdos e dos critérios de avaliação, bem como na introdução de conteúdos, de objetivos e de critérios de avaliação que possibilitem acrescentar elementos na ação educativa, como, por exemplo, sistemas alternativos de comunicação, sistema Braille, alfabeto dígito-manual, entre outros, sendo que parece que tudo que foi dito compete às proposições curriculares que subsidiam a prática docente, não dependendo exclusivamente do professor.

Corroborando, Leite (1999, p.7) acrescenta:

[...] a "gestão flexível do currículo" tem subjacente o princípio da importância da escola e dos professores na configuração curricular, não implicando, portanto, uma estrutura organizacional única e pressupondo, sim, uma adequação do trabalho à diversidade dos contextos e, simultaneamente, a promoção de um ensino de melhor qualidade para todos $^{5}$. Por esta e outras razões, expressei, na altura, a minha adesão a esta forma de "fazer a escola" e de conceber e viver o currículo. E é evi-

5 In: Ministério da Educação (Março, 1998). Educação, integração, cidadania. Documento orientador às políticas para o Ensino Básico, p.19. 
dente que para essas outras razões contribuíram os princípios em que se estrutura esta concepção curricular e que se orientam na linha do que muitos de nós professores há muito reclamávamos quando criticávamos a escola e a formação que é oferecida.

Em casos muito singulares, em que o educando com graves comprometimentos mentais e/ou múltiplos não possa beneficiar-se do currículo da base nacional comum, deverá ser proporcionado um currículo funcional, que poderá ser planejado e acompanhado a partir de um PIE que objetive atender às necessidades práticas da vida (Brasil, 2001). Desta forma, para tais alunos, a flexibilidade deverá concentrar-se nos objetivos, nos materiais, nos conteúdos e na temporalidade utilizando estratégias que priorizem as áreas que garantam funcionalidade e que sejam importantes pré-requisitos para aprendizagens posteriores, na utilização em suas vidas diária e prática, de modo a garantirem o direito à educação mesmo com participação vinculada a um currículo paralelo ao currículo comum.

No que se refere ao processo avaliativo, o aluno com deficiência deve ser avaliado em conformidade com o que conseguiu realizar e aprender, o que ainda não foi possível aprender e aquilo que está em vias de ser aprendido. Logo, o professor necessita focar as atividades escolares em uma perspectiva concreta, utilizando recursos do dia a dia, situações naturais, vivências práticas e adaptações para acesso ao currículo.

Então, cabe indagar: o que se pode preconizar em termos de procedimentos de adaptação e de flexibilização?

Iacono \& Mori (2001, p.7-8) expressam a seguinte contradição:

se o acesso à escola regular [para] os alunos com deficiência mental for tão adaptado (leis e adaptações curriculares significativas), eles não teriam a formação necessária para enfrentar o mundo competitivo fora dos muros da escola (por exemplo, o mundo do trabalho), mas por outro lado, se não lhes forem possibilitadas tais adaptações, talvez a maioria deles não possa ser inserida nas escolas regulares, promovida para séries posteriores e ter acesso a terminalidade de sua escolaridade no ensino fundamental. 
É importante ressaltar que a flexibilização curricular é direito de todos os alunos e que a adaptação é direito de alguns. Tal flexibilização é pautada nas adaptações que a escola e/ou os professores fazem para garantir que os alunos tenham acesso ao currículo, aquele previamente organizado e ofertado a todos os alunos. Destarte, denominam-se adaptações de acesso ao currículo, pois não são necessárias mudanças radicais no currículo da escola, e com este, todos os alunos, com ou sem deficiência, podem se beneficiar.

Todavia, a adaptação curricular é direito de alguns, pois só é permitida a realização desta quando o aluno com deficiência é impedido de acessar o currículo comum aos demais alunos devido às limitações impostas pela deficiência. Neste caso, mostra-se necessário desenvolver para e com o aluno um plano individualizado de ensino (PIE), delineado com ênfase em avaliações criteriosas dos repertórios comportamentais já exibidos pelo aluno, bem como dos objetivos estimados pertinentes e realistas em consideração aos resultados de tais avaliações iniciais. Em suma, o plano individualizado deve conter objetivos e conteúdos que favoreçam as aprendizagens estimadas relevantes, sem que estas ocorram ao acaso, tampouco que prescindam da mediação de ações planejadas e sistemáticas, bem como de orientação pedagógica tangenciada pelas intenções educativas presentes na proposta curricular da escola.

Desta forma, Minetto (2008, p.66) concorda com essa indicação afirmando que:

As adaptações acontecem somente nos casos em que a proposta geral não corresponda efetivamente às necessidades específicas do aluno. Somente em alguns casos teríamos a elaboração de planos verdadeiramente individuais $[. .$.$] no tocante ao cuidado em não criarmos na escola$ dois currículos paralelos: o regular e o especial.

Concernente ao processo de mudança da escola para atender as necessidades educacionais dos alunos, Oliveira \& Leite (2000, p.14) alertam que: 
Deve-se considerar, inclusive, a dificuldade que as escolas têm para administrar a conquista da flexibilização e da sua autonomia, pois está também em suas mãos a responsabilidade de efetivar mudanças que impeçam o processo de exclusão e permitam construir, verdadeiramente, uma escola inclusiva que dê respostas educativas à diversidade, sejam elas sociais, biológicas, culturais, econômicas ou simplesmente, educacionais.

Todavia, considera-se que tais obstáculos não devem ser impeditivos para se alavancar ações nas escolas para não mais perpetuar práticas excludentes, ainda que se tenham metas a curto, médio e longo prazo.

\section{Conclusão}

Embora reconhecendo que a complexidade das questões envolvidas no processo da inclusão escolar acarrete dificuldades para que se possa prognosticar seu esgotamento, as reflexões expostas neste capítulo advogam que, em uma escola inclusiva, o currículo deve ser flexível, de modo a abarcar todas as diferenças humanas, sem que isso impeça as adaptações de acesso ao currículo para os alunos com deficiência e também as adaptações do próprio currículo.

As alterações na rotina escolar devem ocorrer no âmbito do acesso ao currículo, o que se configura flexibilização, pois não são alterados conteúdos estabelecidos no currículo escolar. Paralelamente, o professor deve planejar e executar estratégias didáticas diferenciadas em sua metodologia de ensino e de avaliação, de modo a proporcionar condições adequadas para as aprendizagens criteriosamente estimadas como relevantes. Zanata (2004) argumenta que a implementação de adaptações de sala de aula encontra-se no âmbito de responsabilidade e de ação exclusiva do professor, não exigindo autorização nem dependendo de ação de qualquer outra instância superior, seja na área política ou na administrativa.

As mudanças estruturais do currículo escolar - a adaptação curricular propriamente dita - são estabelecidas após a realização 
do estudo de caso do aluno com deficiência grave participante da sala de aula comum, realizado pela equipe escolar (professor da sala regular, da sala de recursos, coordenador da escola, responsável pelo aluno e, quando possível, o próprio aluno). Nesse contexto, deve ser avaliada a real necessidade de estabelecer tais mudanças, pois não deve ser negado ao aluno o direito de acessar os componentes existentes e determinados no currículo comum a todos os alunos. Desta forma, o ideal é prover o mesmo tipo de currículo escolar a todos os alunos, sendo que as alterações personalizadas deverão ser realizadas "se e quando forem necessárias".

O currículo flexível que acolhe as adaptações curriculares tem na sua proposta pontos de destaque, como por exemplo, a compreensão de que a decisão da necessidade de adaptações não é individual (do professor ou do orientador), mas sim de responsabilidade de todos os envolvidos e, por isso, distribui responsabilidades, incluindo a família. (Minetto, 2008, p.67)

Como a inclusão escolar é processual, diferentes concepções acerca do conceito "adaptação curricular" e de "flexibilização curricular" coexistem no momento. No entanto, a literatura mostrou que se deve utilizá-los como sinônimos. Assim, para a escola deixar de ter o caráter de socialização, apresenta-se como de relevância inconteste o investimento permanente em flexibilizações curriculares. Por sua vez, a execução das adaptações curriculares deve se mostrar contingente à constatação criteriosa de necessidades específicas. Tais adaptações devem priorizar o delineamento de procedimentos que garantam o ensino e a aprendizagem de repertórios e de conteúdos acadêmicos estimados relevantes sem que ocorra o empobrecimento do currículo e a minimização dos direitos de cada aluno à educação de qualidade e, consequentemente, a uma educação inclusiva consciente e eficaz. 


\section{Referências bibliográficas}

BEYER, H. O. Da integração escolar à educação inclusiva: implicações pedagógicas. In: BAPTISTA, C. R. (Org.). Inclusão e escolarização: múltiplas perspectivas. Porto Alegre: Mediação, 2006.

BRASIL. Ministério da Ação Social. Coordenadoria Nacional para a Integração da Pessoa Portadora de Deficiência. Declaração de Salamanca e linha de ação - sobre necessidades educativas especiais. Brasília: MAS/CORDE, 1994.

Parâmetros Curriculares Nacionais - Adaptações curriculares - Educação Especial. Brasília: MEC, 1998.

Parecer $n^{\circ} 17$, Diretrizes Nacionais para a Educação Especial na Educação Básica. Brasília: Conselho Nacional de Educação, 2001.

CAPELLINI, V. L. M. F. Avaliação das possibilidades do ensino colaborativo para o processo de inclusão escolar do aluno com deficiência mental. Dissertação (Doutorado). Universidade Federal de São Carlos. São Paulo, 2004.

COLL, C. Psicologia e currículo: uma aproximação psicopedagógica à elaboração do currículo escolar. São Paulo: Ática, 1996.

IACONO, J. P.; MORI, N. N. R. Deficiência mental e terminalidade específica: novas possibilidades de inclusão ou exclusão velada? In: V ANPED Sul, 2004, Curitiba. Seminário de pesquisa em educação da região Sul - V ANPED SUL. Curitiba: Editora Universitária Champagnat, v.1. p.1-16, 2004.

LEITE, C. A flexibilização curricular na construção de uma escola mais democrática e mais inclusiva. In: Território Educativo. Porto: Direcção Regional de Educação do Norte, n.7, p.20-6, maio 1999.

MAJÓN, D. G; GIL, J. R.; GARRIDO, A. A. Adaptaciones curriculares. Málaga: Ediciones Aljibe, 1997.

MARCHESI, A. Da linguagem da deficiência às escolas inclusivas. In: COLL, C., MARQUESI; PALACIOS, J. Desenvolvimento psicológico e educação: transtornos de desenvolvimento e necessidades educativas especiais. 2.ed. Porto Alegre: Artes Médicas Sul, 2004.

MARQUES, M. do R. L. C. A Problemática do Currículo na Inclusão de Crianças com NEE. Ílhavo, Portugal: 1998. Disponível em: $<$ http://lgp.fl.ul.pt/arquivo /documentos/trabalhoNEE.doc $>$. Acesso em: 09 jun. 2010. 
MINETTO, M. F. Currículo na educação inclusiva: entendendo esse desafio. 2.ed. Curitiba: Ibpex, 2008.

OLIVEIRA, A. A. S.; LEITE, L. P. Escola inclusiva e as necessidades educacionais especiais. In: MANZINI, E. (Org.). Educação Especial: temas atuais. Marília: Unesp Publicações, 2000, p.14-29.

RUIZ, M. J. C.; PEREJA, E. D. Las adaptaciones curriculares como estrategias de atención a la diversidad. In: Educacion Especial: centros educativos y profesores ante la diversidad. Espanha: Ediciones Pirâmide, 2002.

STAINBACK, W.; STAINBACK, S. Inclusão: um guia para educadores. Porto Alegre: Artes Médicas Sul, 1999.

et al. A aprendizagem nas escolas inclusivas: e o currículo? In: Inclusão: um guia para educadores. Porto Alegre: Artes Médicas Sul, 1990.

TAMARIT, J. O aluno com necessidades de apoio generalizado. In: COLL, C., MARQUESI, A.; PALACIOS, J. Desenvolvimento psicológico e educação: transtornos de desenvolvimento e necessidades educativas especiais. 2.ed. Porto Alegre: Artes Médicas Sul, 2004.

ZANATA, E. M. Práticas pedagógicas inclusivas para alunos surdos numa perspectiva colaborativa. Dissertação (Doutorado). Universidade Federal de São Carlos, São Carlos, 2004. 



\title{
2 \\ RECURSOS UTILIZADOS POR PROFESSORAS PARA SE COMUNICAREM COM ALUNOS COM SÍNDROME DE ASPERGER EM SALA DE AULA COMUM
}

\author{
Maria Cláudia Brito ${ }^{1}$ \\ Kester Carrara ${ }^{2}$ \\ Débora Deliberato ${ }^{3}$
}

\section{Introdução}

Este capítulo relata uma análise motivada e subsidiada pelos resultados encontrados na dissertação Análise do perfil comunicativo de alunos com transtornos do espectro autístico na interação com seus professores (Brito, 2007). O estudo realizado na dissertação referiuse às habilidades comunicativas de alunos com distúrbios do espectro autístico (DEA) em sala de aula comum e permitiu verificar correlação estatística positiva altamente significante entre as iniciativas comunicativas dos alunos com DEA e suas professoras. Os resultados indicaram uma relação de interdependência entre os comportamentos comunicativos de professoras e seus alunos com DEA, como observado por outros autores (Tjus et al., 2001).

Assim, com base nos resultados encontrados por Brito (2007) e descritos por Brito \& Carrara (no prelo), sugere-se a necessidade de analisar os recursos entre as professoras e seus alunos nas situações

1 Programa de Pós-Graduação em Psicologia do Desenvolvimento e Aprendizagem da Unesp - Bauru.

2 Idem.

3 Programa de Pós-Graduação em Educação da Unesp - Marília. 
de interação, para que se possa pensar em caminhos para as adequações ou modificações necessárias aos processos de comunicação da criança com DEA.

Os DEA se referem a indivíduos que compartilham algumas das principais manifestações clínicas do autismo em diferentes graus de severidade (Vanbergeijk et al., 2008), sendo caracterizados pelo início precoce de atrasos e desvios no desenvolvimento das habilidades sociais, comunicativas e comportamentais (Wing et al., 2002).

A definição de recurso é aqui entendida como um material utilizado no procedimento pedagógico que pode possibilitar um ensino voltado para as necessidades de cada aluno. Desenvolver recursos que garantam a acessibilidade às informações constitui uma maneira de neutralizar as barreiras e inserir esse indivíduo em ambientes ricos para a aprendizagem (Galvão \& Damasceno, 2000).

Como afirmaram Drew et al. (2007), o comportamento comunicativo de crianças com DEA está relacionado ao apoio oferecido pelo adulto. Segundo Schmit (1984), os momentos e as oportunidades para a adoção de um ou outro recurso, e especialmente a combinação de vários deles, devem ser selecionados pelo professor, na medida de sua necessidade e dos resultados que se pretende alcançar.

Pode-se favorecer a educação inclusiva quando os professores estiverem capacitados na diversidade de recursos e aplicarem procedimentos adaptados às necessidades específicas de cada aluno, como é possível apontar em relação aos aspectos comunicativos (Alant, 2000; Deliberato, 2008). Nunes (2001) discutiu a importância dos recursos de comunicação alternativa para o ensino de alunos com deficiência e destacou a importância da capacitação de professores para o uso adequado e sistemático dos sistemas gráficos na escola.

Neste estudo, foi enfatizada a necessidade da busca, por parte de professores, de recursos que favoreçam o aprendizado, a comunicação e a socialização de alunos com a síndrome de Asperger. White et al. (2006) discutiram que entre os DEA há maior inserção de crianças com síndrome de Asperger em contextos de educação inclusiva, pois são alunos com características e sintomatologia mais brandas 
(Paul et al., 2009), associadas à inteligência normal (Klin, 2006), e com melhores resultados acadêmicos e sociais.

Assim, o objetivo deste estudo foi investigar os recursos utilizados por professoras na comunicação com alunos com diagnóstico de síndrome de Asperger em situações de sala aula comum de escolas públicas.

\section{Método ${ }^{4}$}

Participantes: cinco crianças, do gênero masculino, com idades variáveis entre cinco e oito ano, com diagnósticos de síndrome de Asperger, com testes realizados segundo os critérios estabelecidos pela CID-10 (1993) e pelo DSM-IV (2002). Todos eram alunos de escolas municipais de Educação Infantil e escolas estaduais de Ensino Fundamental, do jardim II à $2^{\mathrm{a}}$ série, ${ }^{5}$ de uma cidade do interior de São Paulo, conforme a Tabela 1.

Quanto à caracterização das professoras, verificou-se que todas eram do gênero feminino. No que se refere à experiência profissional, as professoras tinham entre dez e vinte anos de experiência no ensino comum, nenhuma possuía experiência prévia no ensino de alunos autistas ou com síndrome de Asperger e apenas uma tinha experiência com alunos com outros tipos de deficiência. Além disso, dentre as cinco participantes, duas haviam concluído cursos de graduação, quatro cursaram Magistério, apenas uma realizou curso de formação continuada (Psicopedagogia) e nenhuma delas tinha formação profissional na área de autismo (Tabela 1).

4 Esta pesquisa foi submetida à Comissão de Ética para Pesquisa da Faculdade de Ciências da Universidade Estadual Paulista, campus de Bauru, sob o protocolo ${ }^{\circ} 011924$.

5 Todas as referências a séries e níveis de ensino mencionados no corpo deste texto referem-se à nomenclatura utilizada no Brasil no momento em que foi realizada a pesquisa. 


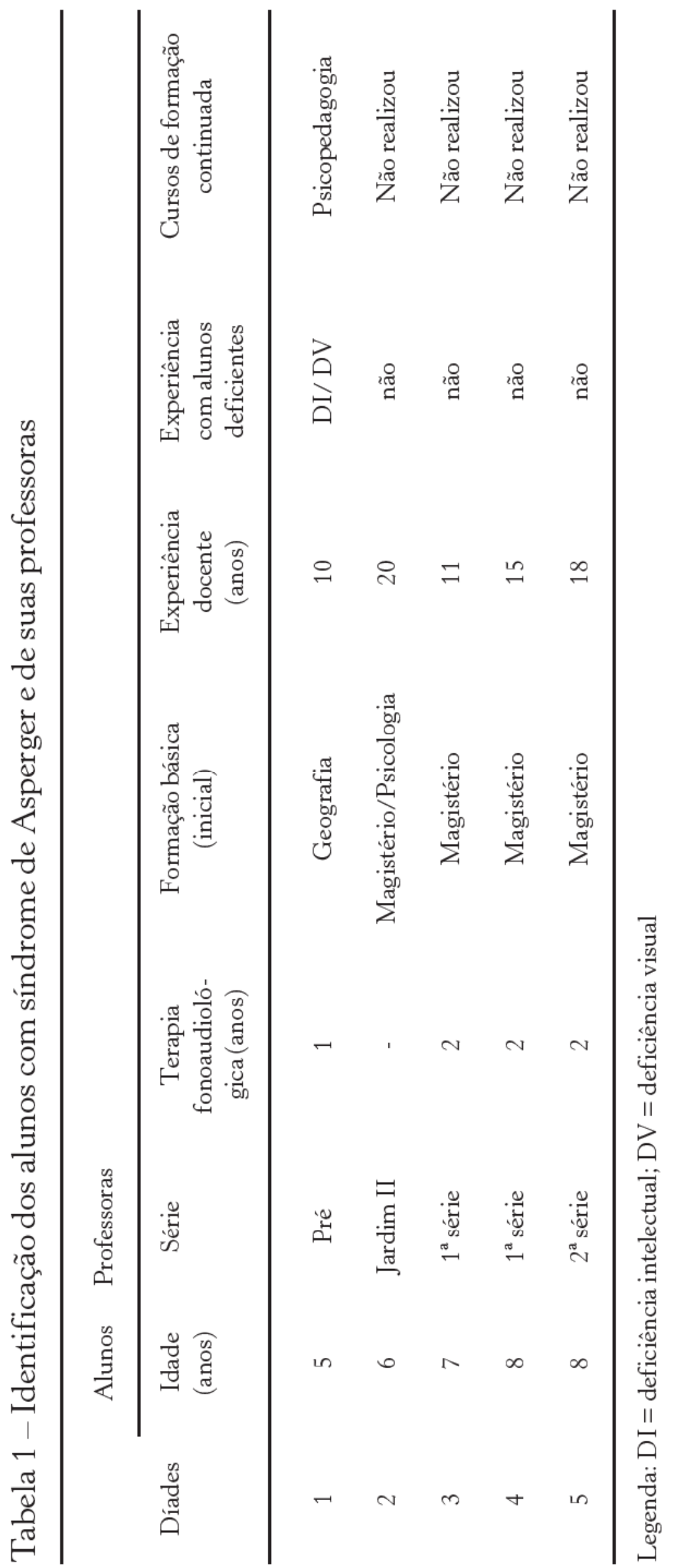




\section{Instrumentos para a coleta de dados}

Os instrumentos utilizados foram uma câmera de vídeo para o registro contínuo das interações entre os professores e seus alunos participantes da pesquisa e uma ficha de controle de filmagem.

Os dados dos participantes e das filmagens foram registrados na ficha de controle de filmagem, elaborada para esse fim. A ficha contém informações como: identificação da criança, identificação da professora e informações sobre sua formação e experiência profissional, data da filmagem, número da fita gravada e comentários, permitindo, assim, a caracterização dos participantes e a descrição das atividades realizadas em cada filmagem.

\section{Procedimentos de coleta e análise de dados}

O procedimento de coleta de dados foi organizado após o estudo piloto com uma professora e seu aluno com síndrome de Asperger em duas situações que tinham por objetivo atividades envolvendo comunicação entre ambos. Após a conclusão do estudo piloto, foi realizado o mesmo procedimento com cada uma das cinco professoras participantes dessa pesquisa. As filmagens foram realizadas pela própria pesquisadora, que não interagiu diretamente com os alunos ou com as professoras, limitando-se a filmar as atividades em silêncio. Desta forma, cada díade professora-aluno foi filmada duas vezes, no primeiro semestre do ano letivo, com intervalo de uma semana para cada filmagem. As atividades realizadas em sala que foram filmadas eram iguais na primeira e na segunda filmagem de cada díade.

O tratamento dos dados foi realizado a partir de análise qualitativa (Barros \& Lehfeld, 1988), isto é, as filmagens foram avaliadas por meio da análise de conteúdo, tal como descreveu Bardin (2004). A análise de dados iniciou-se com a transcrição na íntegra das filmagens. Após essa etapa, foram analisados os conteúdos de tais filmagens com base em temas prévios, fundamentados em estudos científicos que abordam a temática de recursos e procedimentos al- 
ternativos de comunicação para pessoas com deficiência(Deliberato; 2008) e a comunicação e intervenção de indivíduos com a síndrome de Asperger (Fernandes et al., 2008; Brito, 2007; Klin, 2006; Klin, 2003).

Para o material obtido após a transcrição, foi considerada como categorização a classificação de elementos constitutivos de um conjunto por diferenciação e em seguida por reagrupamento segundo o gênero, com critérios previamente definidos (Bardin, 2004). Não houve preocupação com a transcrição fonética pelo fato de esta característica não fazer parte do objetivo da pesquisa. Assim, após a realização da transcrição das filmagens, foram realizados os seguintes procedimentos: leitura integral para levantamento de temas gerais; elaboração de agrupamentos, categorias de respostas mutuamente excludentes; realização da análise dos agrupamentos em função da literatura consultada; e análise dos dados procurando responder ao objetivo do estudo, qual seja, investigar os recursos utilizados por professoras de ensino comum na comunicação com alunos que apresentam a síndrome de Asperger.

Foram identificados como recursos utilizados pelas professoras na comunicação: expressões verbais, relativas a sons vocálicos, sílabas e palavras articuladas; expressões não verbais, que se referem a sorriso, olhar, movimentos corporais, como expressões faciais, gestos manuais; e instrumentos e materiais concretos manipuláveis empregados na mediação da comunicação.

\section{Resultados}

A análise do conteúdo das dez situações filmadas permitiu a identificação de quatro categorias de recursos utilizados pelas professoras na comunicação com seus alunos com síndrome de Asperger, que foram as seguintes:

1- Objeto concreto: estímulo concreto que possa ser manipulável; instrumentos e materiais concretos utilizados para comunicar algo ou para complementar a comunicação. 
2- Gesto: movimentos realizados com as mãos, expressão facial e corporal com intenção comunicativa.

3-Escrita: a escrita propriamente dita de letras e palavras.

4- Verbalização: emissões orais inteligíveis, correspondentes ou semelhantes aos padrões fonoarticulatórios da comunidade linguística, como palavras e frases.

Essas quatro categorias de recursos foram identificadas com base no conteúdo expresso durante as situações filmadas, podendo ter sido utilizadas todas em uma mesma situação de interação, ou ainda um ou outro tipo em cada situação. A seguir, as categorias de recursos são abordadas por meio de exemplos extraídos das transcrições realizadas.

\section{Categoria 1 - Objeto concreto}

Como mostra a Tabela 2, a utilização de objeto concreto esteve presente na mediação da comunicação em sete das dez situações analisadas, sendo que em cinco situações os objetos utilizados foram apenas lousa e giz; além disso, foram também utilizados lápis de cor e papel sulfite, livros e caderno.

Tabela 2 - Exemplos de ocorrência da categoria Objeto concreto

Exemplo 1 Contexto de interação: A P4 leu a história posicionada em frente à classe, com o livro nas mãos, mas sem utilizar as figuras deste como apoio para os alunos, que se encontravam sentados em suas carteiras individuais e enfileiradas. Após a leitura, P4 realizou verbalmente uma série de perguntas sobre a história, que os alunos deveriam responder verbalmente, enquanto ela registrava as respostas corretas na lousa, para trabalhar a interpretação da história.

P4: "E qual a moral a história? Vamos escrever agora!" (com giz na mão apontando para a lousa). 
A4: Estabelece contato visual restrito com a professora, olha brevemente para a lousa e desvia o olhar sem responder à pergunta da professora. A maior parte dos demais alunos respondeu verbalmente a questão. P4: Escreve na lousa a moral da história, enquanto diversos alunos respondem à pergunta realizada por ela. A4: Continua com o contato visual restrito na direção da lousa e realiza alguns movimentos estereotipados com as mãos, enquanto a professora continua a falar sobre a história (o local onde o aluno está sentado, distante da professora, dificulta a possibilidade de ela chamar sua atenção).

Legenda: $\mathrm{P}=$ professora; $\mathrm{A}=$ aluno

\section{Categoria 2 - Gesto}

O uso de gestos, como expressões faciais, gestos manuais e posturas corporais, foi verificado em todas as situações analisadas, como era esperado, por esse geralmente ser um recurso cotidianamente empregado na comunicação e frequentemente associado à fala.

Entretanto, notaram-se algumas variações na qualidade do uso desse recurso, sendo que duas professoras (P1 e P5) manifestaram restrita expressão facial e pouco contato visual com seus alunos com síndrome de Asperger, e as outras três (P2, P3 e P4) demonstraram padrão típico, sem adaptações. Os exemplos da Tabela 3 ilustram algumas situações.

Tabela 3 - Exemplos de ocorrência da categoria Gesto

Exemplo 2 Contexto de interação: A P1 distribuiu folhas com desenhos temáticos e lápis de cor aos alunos e os orientou a pintar os desenhos. Depois a P1 foi pendurar no mural da sala de aula desenhos realizados outro dia pelos alunos. 
A1: Levanta-se da carteira, vai a uma caixa localizada no canto da sala, pega um livro, começa a folheá-lo e olha para a P1.P1: Olha para o A1, mas não fala nada.A1: Coloca o livro na caixa novamente, volta à sua carteira, mas não inicia a atividade de pintura e realiza movimentos estereotipados com as mãos, olhando para a P1.P1: Olha para o A1, mas não fala nada.A1: Levanta-se, vai até a P1 e coloca as mãos no desenho localizado ao lado do desenho que a P1 pendura no mural.P1: "O que você quer? Espere um pouco."A1: Dá um lápis para a P1, volta à sua carteira, realiza movimentos estereotipados com as mãos e mostra a língua.P1: Olha para a criança e continua pendurando os desenhos.

Legenda: $\mathrm{P}=$ professora; $\mathrm{A}=$ aluno

\section{Categoria 3 - Escrita}

Assim como o objeto concreto, a escrita esteve presente em cinco das dez situações analisadas, todavia esse recurso também foi utilizado de modo usual, sem que se buscasse adaptá-lo e oferecê-lo como apoio em situações nas quais somente a informação auditiva parece não ter sido suficiente para o aluno com síndrome de Asperger compreender plenamente as atividades propostas. $\mathrm{O}$ uso desse recurso pode ser observado em exemplos já mencionados e nos exemplos $3 \mathrm{e}$ 4 das Tabelas 4 e 5, respectivamente.

Tabela 4 - Exemplos de ocorrência da categoria Escrita

Exemplo 3 Contexto de interação: A P3 pergunta à classe os nomes de cada aluno em ordem alfabética e os escreve na lousa. 
P3: "Quem é que é a primeira criança da classe com a letra J?” (escreve J na lousa).A3: “João, Jo-sé, João, Júlia, João, Jo-sé, João, Jú-lia” (ecolalia imediata da fala de outros alunos).P3: "Não, oh! A Júlia já cai fora." A3: "A Júlia já cai fora! A Júlia já cai fora!" (ecolalia imediata da fala da professora).

Legenda: $\mathrm{P}=$ professora; $\mathrm{A}$ = aluno

\section{Categoria 4 - Verbalização}

A verbalização foi o recurso mais empregado e foi observado em todas as situações analisadas. Tal fato já era esperado, considerando que nos contextos de sala de aula de ensino comum a fala é o recurso convencionalmente mais utilizado. Entretanto, não se verificou nem mesmo traços suprassegmentais da fala, como padrões de inflexão e modulação vocal diferenciados, que buscassem favorecer a compreensão dos alunos com síndrome de Asperger. Pode ser verificada a utilização do recurso da categoria verbalização em exemplos já mencionados e no exemplo 4 da Tabela 5.

Tabela 5 - Exemplos de ocorrência da categoria Verbalização

Exemplo 4 Contexto de interação: A P3 chama um aluno na lousa para escrever as frases que serão compostas pelos alunos com auxílio da professora. As frases referem-se a acontecimentos do dia.

A3: "Eu qui vô iscreve!”P3: "Hoje não é seu dia!”A3: "Naaaaaão! Sô eu!" ("grita” com a professora).A3: Prooô!P3: "E aí, qual vai sê a frase que vai escrevê?" (questionando a sala e ignorando o pedido do aluno). 


\section{Discussão}

Os resultados deste estudo evidenciaram a restrita utilização de recursos adaptados para alunos com a síndrome de Asperger, uma vez que nas quatro categorias encontradas (1-Objeto concreto; 2Gesto; 3- Escrita; 4-Verbalização), os recursos utilizados pelas professoras foram empregados apenas de modo convencional.

A categoria Objeto concreto esteve presente na mediação da comunicação em sete das dez situações analisadas, sendo que em cinco situações os objetos utilizados foram apenas lousa e giz, e em duas das situações, foram lápis de cor e papel sulfite, e em outra, caderno. Esses dados evidenciaram a restrita utilização de materiais concretos e manipuláveis, adaptados para alunos com a síndrome de Asperger.

Pesquisadores relataram que alunos com síndrome de Asperger podem ser detalhistas e perfeccionistas e ficar altamente frustrados e ansiosos quando se deparam com materiais que não entendem ou quando sentem que estão abaixo do padrão esperado (Marks et al., 2003).

A literatura demonstra a relevância de se explorar a utilização de objetos concretos como recursos alternativos para favorecer a comunicação de indivíduos com DEA (Ganz \& Simpson 2004; Mirenda, 2003), que podem responder melhor a estímulos visuais, sendo importante não restringir-se à informação auditiva (Marks et al., 2003; Grandin, 2006), o que não foi observado nesse estudo.

Alguns estudos relataram símbolos gráficos e fotografias como auxílio de grande valia e com resultados favoráveis (Ganz \& Simpson, 2004), pois os alunos podem compreender melhor os enunciados e, consequentemente, informar seus desejos e necessidades (idem, ibidem). Outros recursos adaptados também podem contribuir para a comunicação de alunos com DEA em contexto escolar, como o uso de sistemas gráficos com alta tecnologia - como o Vocas (Voice Output Communication Aids), que consiste em recursos eletrônicos portáteis com sintetizador de voz ou voz digitalizada (Mirenda, 2003); uso de computadores (Markiewicz \& MacQueen, 2009); 
pagers vibratórios como lembretes táteis para que a criança prestasse atenção ao professor ou a uma determinada atividade (Anson et al., 2008) - e com baixa tecnologia, como as pranchas básicas, temáticas e o uso do Pecs (Picture Exchange Communication Symbols) (Ganz et al., 2008), entre outros.

Quanto à categoria Gesto, o uso de expressões faciais, gestos manuais e posturas corporais foi verificado em todas as situações analisadas. Esse resultado já era esperado, pois os gestos são recursos cotidianamente empregados nas interações. Como apontaram Acosta et al. (2006), para entender o significado das emissões vocais e verbais é necessária uma análise que supere a descrição formal e vá além da frase, examinando os comportamentos gestuais, as expressões faciais e as características do contexto.

Entretanto, notaram-se algumas variações na qualidade do uso desse recurso, sendo que duas professoras (P1 e P5) manifestaram restrita expressão facial e pouco contato visual com seus alunos com síndrome de Asperger, e as outras três (P2, P3 e P4) demonstraram padrão típico, sem adaptações.

Alunos com síndrome de Asperger demonstram alterações nas interações sociais (Brito \& Carrara, no prelo; Hagberg et al., 2010; Brito, 2007) e dificuldades em interpretar expressões gestuais e as intenções de outras pessoas (Klin, 2006). Portanto, podem ser necessários recursos de apoio para a plena compreensão de determinadas mensagens gestuais (idem, 2003), o que não se verificou nesta pesquisa.

No que se refere à categoria Escrita, esta se mostrou presente em cinco das dez situações analisadas. Todavia, esse recurso também foi utilizado apenas de modo usual, sem que se buscasse adaptá-lo e oferecê-lo como apoio em situações nas quais somente a informação auditiva parece não ter sido suficiente para o aluno com síndrome de Asperger compreender integralmente as atividades propostas. Esses achados mostraram que as professoras não aproveitaram um recurso descrito pela literatura como estimulante (Johnston et al., 2009; Grandin, 2006) e em muitos casos preferencial para tais alunos (idem, ibidem). 
Os educadores podem adaptar a leitura aos interesses e habilidades das crianças com autismo ou síndrome de Asperger (Libling, 2000), que frequentemente se fixam em algo, podendo ser bastante eficaz utilizar esses interesses específicos nas adequações curriculares e organizacionais em contexto escolar. Por exemplo, se uma criança gosta de trens, o professor poderia utilizar trens para trabalhar a leitura, a matemática, entre outros aspectos (Grandin, 2006).

Além disso, o uso de símbolos gráficos permite que a informação permaneça por um maior período de tempo em relação à palavra falada, em que os estímulos sonoros se esvaecem rapidamente, o que pode dificultar o processo de comunicação desses alunos (Mirenda, 2003).

No que tange à categoria Verbalização, foi o recurso mais empregado, sendo observado em todas as situações analisadas. Assim como no caso da categoria Gesto, esta ocorrência também era esperada, pois em classe comum a fala é o recurso convencionalmente mais utilizado. Entretanto, na presente pesquisa não se verificaram traços suprassegmentais da fala, como padrões de inflexão e modulação vocal diferenciados, que buscassem favorecer a compreensão por parte dos alunos com síndrome de Asperger. Conforme Klin (2003), em qualquer intervenção com indivíduos com síndrome de Asperger, a comunicação deve envolver a linguagem não literal (uso de metáforas, ironias, humor), traços suprassegmentais da fala (padrões de inflexão e modulação vocal), pragmática (troca de turnos, sensibilidade sobre as reações do interlocutor) e conteúdo e contingência da conversação.

Como ressaltaram alguns autores, entre as principais dificuldades dos educadores em atuar com alunos com DEA destaca-se a manutenção de habilidades comunicativas (Probst \& Leppert, 2008), pois mesmo as crianças que apresentam oralidade têm dificuldades para responder a perguntas, compartilhar e pedir informações (Wetherby et al., 2000) e para estruturar narrativas (Diehl et al., 2006).

Alguns pesquisadores sugerem que não há uma abordagem específica de intervenção que seja mais efetiva para todas as crianças 
com transtornos invasivos do desenvolvimento (Fernandes et al., 2008), pois embora compartilhem muitas características, esses indivíduos podem ser muito diferentes entre si. Assim, o nível e a intensidade de apoios necessários a um determinado estudante dependerão em grande parte de suas características individuais (Harrower \& Dunlap, 2001).

Portanto, a análise dos resultados mostrou que embora todas as professoras participantes tivessem dez ou mais anos de experiência como docente e conhecimento do diagnóstico de seus alunos, não utilizaram recursos e procedimentos diferenciados para favorecer a participação desses estudantes. Assim, conforme Deliberato \& Manzini (2006), a seleção da melhor modalidade expressiva para viabilizar uma interação efetiva, em função do contexto comunicativo e dos interlocutores presentes, é uma habilidade que deve ser ensinada e orientada aos educadores.

A conduta das professoras observada nesta pesquisa pode estar relacionada ao fato de essas profissionais não terem formação específica na área, não terem recebido nenhuma orientação sobre como atuar nesses casos e também por não terem buscado cursos ou orientações mesmo depois de receberem esses alunos. Além disso, as professoras parecem não ter procurado compreender as necessidades desses alunos, para realizar adaptações às estratégias de ensino e, assim, facilitar a aprendizagem.

Tais achados corroboram as colocações de diversos autores sobre o escasso respaldo oferecido a educadores acerca da inclusão educacional de alunos deficientes, em particular de alunos com DEA (White et al., 2006; Marks et al., 2003). Essa formação deficitária pode contribuir para que os professores do ensino comum se sintam despreparados e tenham dificuldades em lidar com uma forma de comunicação não convencional (Alant, 2000).

Além disso, podem confiar em estratégias generalistas não adequadas, e, como consequência, não conseguir atingir as necessidades acadêmicas, sociais e comportamentais desses alunos (White et al., 2006). Pesquisas atestaram resultados positivos quando os professores de crianças com DEA são bem respaldados, como aumento 
de fala (Chiang, 2009) e de iniciativas comunicativas (Howlin et al., 2007), redução das reações de tensão dos professores e melhora nas interações sociais (Probst \& Leppert, 2008).

\section{Conclusão}

Os dados aqui obtidos demonstraram que os recursos empregados pelas professoras com o objetivo de se comunicar com seus alunos com síndrome de Asperger foram gestos manuais, olhares, expressões faciais, vocalizações, verbalizações, escrita e objetos concretos, com predileção por gestos e pela fala. Embora todas as professoras tivessem dez ou mais anos de experiência docente e conhecimento do diagnóstico de seus alunos, a utilização de todos os recursos ocorreu de forma convencional, sem qualquer adaptação, o que demonstrou não ter sido suficiente para garantir que as reais necessidades desses alunos fossem atendidas.

Mesmo considerando-se que esses dados se referiam apenas às sessões de coleta de dados realizadas, não se justificaria o argumento de que seria necessário o registro de um maior número de sessões, ou com maior período de tempo de situações de sala de aula, para a identificação do uso de recursos adaptados, pois, evidentemente, aumentar a amostra analisada contribuiria para o esclarecimento do problema investigado, mas a seleção e a adaptação de materiais a serem utilizados nas aulas devem ser consideradas em tempo integral.

Os resultados aqui descritos sugerem ainda a necessidade da colaboração da família e de outros profissionais atuando com o professor do ensino comum, no sentido de promoverem atuações colaborativas para o ensino do aluno com deficiência. Ampliar o uso de recursos da tecnologia assistiva na escola poderia promover o desenvolvimento e a aprendizagem infantil dos alunos com deficiência, e assim o acesso à aquisição da leitura e da escrita, por meio da utilização de recursos adaptados, dependendo das necessidades de cada aluno. 


\section{Referências bibliográficas}

ACOSTA, V. M. et al. Avaliação do desenvolvimento pragmático. In: Avaliação de linguagem: teoria e prática do processo de avaliação do comportamento linguístico infantil. s. 1.: s. n., 2006.

ALANT, E. Training teachers to interact with AAC users in the classroom. Augmentative and Alternative Communication, Washington, v.2, n.6, p.5-7, ago. 2000.

AMERICAN PSYCHIATRY ASSOCIATION. Manual diagnóstico estatístico de transtornos mentais. (DSM-IV-TR). Porto Alegre: Artes Médicas, 2002.

ANSON, H. M.; TODD, J. T.; CASSARETTO, K. J. Replacing overt verbal and gestural prompts with unobtrusive covert tactile prompting for students with autism. Behav. Res. Methods, v.40, n.4, p.1106-10, nov. 2008.

BARDIN, L. Análise de conteúdo. 3.ed. São Paulo: Edições 70, 2004.

BARROS, A. J. P.; LEHFELD, N. A. S. Projeto de pesquisa: propostas metodológicas. 10.ed. Petrópolis: Vozes, 1988.

BRITO, M. C. Análise do perfil comunicativo de alunos com transtornos do espectro autístico na interação com seus professores. Dissertação (Mestrado em Psicologia do Desenvolvimento e Aprendizagem). Universidade Estadual Paulista, Bauru, 2007.

; CARRARA, K. Alunos com distúrbios do espectro autístico em interação com professores na educação inclusiva: descrição de habilidades pragmáticas. Revista da Sociedade Brasileira de Fonoaudiologia. No prelo.

CHIANG, H. M. Naturalistic observations of elicited expressive communication of children with autism: an analysis of teacher instructions. Autism, v.13, n.2, p.165-78, mar. 2009.

DELIBERATO, D. Comunicação alternativa: informações básicas para o professor. In: OLIVEIRA, A. S.; OMOTE, S.; GIROTO, C. M. Inclusão escolar: as contribuições da Educação Especial. São Paulo: Cultura Acadêmica Editora, 2008, v.1, p.233-50.

MANZINI, E. J. Fundamentos introdutórios em comunicação suplementar e/ou alternativa. In: GENARO, K. F.; LAMÔNICA, D. A. C.; BEVILACQUA, M. C. (Orgs.). O processo de comunicação: contribuição para a formação de professores na inclusão de in- 
divíduos com necessidades educacionais especiais. São José dos Campos: Pulso, 2006, p.243-54.

DIEHL, J. D.; BENNETTO, L.; YOUNG, E. C. Story recall and narrative coherence of high-functioning children with autism spectrum disorders. Journal of Abnormal Child Psychology, v.34, p.87102, 2006.

DREW. A. et al. The social communication assessment for toddlers with autism (SCATA): an instrument to measure the frequency, form and function of communication in toddlers with autism spectrum disorder. J. Autism. Dev. Disord., v.37, p.648-66, 2007.

FERNANDES F. D. et al. Fonoaudiologia e autismo: resultado de três diferentes modelos de terapia de linguagem. Pró-Fono Revista de Atualização Científica, v.20, n.4, p.267-72, out.-dez. 2008.

GALVÃO, T. A. F.; DAMASCENO, L. L. As tecnologias da informação e da comunicação como tecnologia assistiva. Brasília: PROINFO/ MEC, 2000.

GANZ, J. B.; SIMPSON, R. L. Effects on communicative requesting and speech development of the picture exchange communication system in children with characteristics of autism. Journal of Autism and Developmental Disorders. v.34, n.4, aug. 2004.

et al. Generalization of a pictorial alternative communication system across instructors and distance. Augment Altern. Commun., v.24, n.2, p.89-99, 2008.

GRANDIN, T. Perspectives on education from a person on the autism spectrum. In: Educational Horizons. v.84, n.4, p.229-34, sum. 2006.

HAGBERG, B. S.; MINISCALCO, C.; GILlBERG, C. Clinic attenders with autism or attention-deficit/hyperactivity disorder: cognitive profile at school age and its relationship to preschool indicators of language delay. Res. Dev. Disabil. v.31, n.1, p.1-8, jan.feb. 2010. ePub aug. 26, 2009

HARROWER, J. K.; DUNLAP, G. Including children with autism in general education classrooms: a review of effective strategies. Behavior Modification. v.25, n.5, p.762-84, oct. 2001.

HOWLIN, P. et al. The effectiveness of Picture Exchange Communication System (PECS) training for teachers of children with autism: a pragmatic, group randomised controlled trial. J. Child Psychol. Psychiatry, 48(5), p.473-81, may 2007. 
JOHNSTON, S. S.; BUCHANAN, S.; DAVENPORT, L. Comparison of fixed and gradual array when teaching sound-letter correspondence to two children with autism who use AAC. Augment. Altern. Commun., v.25, n.2, p.136-44, jun. 2009.

KLIN, A. Asperger syndrome: an update. Revista Brasileira de Psiquiatria, n.2, p.103-9, 2003.

Autismo e síndrome de Asperger: uma visão geral. Revista Brasileira de Psiquiatria. n.28, p.3-11, 2006 (Suplemento 1).

LIBLING, M. M. Preparing children with early childhood autism for schooling. Russian Education and Society, v.42, n.5, p.28-55, may 2000.

MARKIEWICZ, K.; MacQUEEN, B. D. The autistic mind: a case study. Med. Sci. Monit, v.15, n.1, p.5-13, jan. 2009.

MARKS, S. U. et al. Instructional management tips for teachers of students with autism spectrum disorder (ASD). Teach. Except. Child., v.35, n.4, mar.-apr. 2003.

MIRENDA, P. Toward functional augmentative and alternative communication for students with autism. Manual signs, graphic symbols and Voice Output Communication Aids. Language, Speech, and Hearing Services in Schools, v.34, p.203-16, jul. 2003.

NUNES, L. R. O. P. et al. Narrativas sobre fotos e vídeos e narrativas livres através de sistema gráfico de Comunicação Alternativa. In: (Org.). Favorecendo o desenvolvimento da comunicação em crianças e jovens com necessidades educacionais especiais. Rio de Janeiro: Dunya, 2003. p.143-69.

ORGANIZAÇÃO MUNDIAL DE SAÚDE. Classificação de Transtornos Mentais de Comportamento - CID-10: critérios diagnósticos para pesquisa. 10.ed. Porto Alegre: Artes Médicas, 1993.

PAUL, R. et al. Conversational behaviors in youth with high-functioning ASD and Asperger syndrome. Journal of Autism Development Disordras n.39, p.115-25, 2009.

PROBST, P.; LEPPERT, T. Outcomes of a teacher training program for autism spectrum disorders. Journal of Autism and Developmental Disorders, n.38, p.1791-6, 2008.

TJUS, T.; HEIMANN, M.; NELSON, K. E. Interaction patterns between children and their teachers when using a specific multimedia and communication strategy observations from children with autism and mixed intellectual disabilities. Autism, v.5, n.2, p.175-87, 2001. 
VANBERGEIJK, E.; KLIN, A.;VOLKMAR, F. Supporting more able students on the autism spectrum: college and beyond. Journal of Autism and Development Disordens n.38, p.1359-70, 2008.

WETHERBY, A. M.; PRIZANT, B. M.; SCHULER, A. L. Understanding the nature of communication and language impairments. In: (Eds.). Autism spectrum disorders: a transactional developmental perspective. Baltimore, MD: Brookes Publishing, 2000.

WHITE, S. W. et al. Educational placements and service use patterns of individuals with autism spectrum disorders. Journal of Autism and Development Disordens, 2006.

WING, L. et al. The diagnostic interview for social and communication disorders: background, inter-rater reliability and clinical use. Journal of Child Psychology and Psychiatry. n.43, p.307-25, 2002. 



\title{
3 \\ VolTA ÀS AULAS AOS SESSENTA ANO: PERFIL DOS ALUNOS DE UMA UNIVERSIDADE ABERTA À TERCEIRA IDADE ${ }^{1}$
}

\author{
Lauren Mariana Mennocchi ${ }^{2}$ \\ Lúcia Pereira Leite ${ }^{3}$
}

\section{Introdução}

O aumento geral da expectativa de vida da população tem mobilizado países desenvolvidos e em desenvolvimento para a elaboração de políticas públicas destinadas a atender as necessidades de um novo contingente populacional. As melhores condições de urbanização das cidades e os avanços médicos possibilitaram uma maior expectativa de vida em todo o mundo e, como consequência, despertaram o interesse da ciência no estudo do envelhecimento (Paskulin \& Viana, 2007).

A Psicologia se configurou entre as primeiras áreas científicas a se dedicar ao tema e, a partir da década de 1950, com a expansão de suas pesquisas, acabou produzindo profundas mudanças na própria

1 Este texto é um recorte da dissertação de mestrado Representações sociais de professores e alunos sobre envelhecimento e educação em um programa de Universidade Aberta à Terceira Idade, apresentada no ano de 2009, no Programa de Pós-Graduação em Psicologia do Desenvolvimento e Aprendizagem pela primeira autora, sob orientação da segunda autora.

2 Programa dePós-Graduação em Psicologia do Desenvolvimento e Aprendizagem da Unesp - Bauru.

3 Idem. 
compreensão do desenvolvimento que, até então, era um conceito equivalente ao da infância. Porém, foi somente a partir dos anos 1970 que os conceitos de envelhecimento e desenvolvimento, tradicionalmente tratados como antagônicos, foram conciliados. A resolução dessa questão foi um dos principais objetivos da perspectiva teórica conhecida como life-span ou curso de vida (Neri, 2001).

O envelhecimento, nessa perspectiva, é uma propriedade exclusiva dos organismos vivos e que, para os seres humanos, compreende os processos de transformação do organismo que ocorrem após a maturação sexual e que implicam na diminuição gradual da probabilidade de sobrevivência. Esses processos são de natureza interacional, iniciam-se em diferentes épocas e ritmos e acarretam resultados distintos para as diversas partes e funções do organismo.

Essas transformações, que ocorrem durante todo o curso de vida, não somente se referem aos ganhos em um movimento unidirecional de crescimento dos organismos, mas às perdas decorrentes desse mesmo processo (idem, ibidem).

Assim, como viver implica perdas e ganhos e se dá em um processo contínuo, descrever quais são as mudanças típicas do envelhecer não é tarefa simples e sequer possível, haja vista que uma das principais características do envelhecimento humano é sua heterogeneidade de experiências, devido ao seu caráter ativo imposto pelo próprio organismo e sob influência de diversos fatores sociais, históricos, culturais e psicológicos (idem, 1993; 2001; Papaléo Netto \& Borgonovi, 2002).

Neste texto, a compreensão de desenvolvimento humano na velhice (ou em qualquer outra fase da vida, uma vez que se trata de um mesmo processo) pautou-se nas contribuições da Psicologia Histórico-Cultural, especialmente nos postulados de Vygotsky e seus colaboradores.

Apesar de não fazer menção ao envelhecimento humano, a compreensão de Vygotsky sobre desenvolvimento e sobre o próprio homem parece bem servir às análises aqui propostas e fundir-se com os enunciados acima citados sobre o caráter histórico e social da velhice. 
Mais que isso, o autor propõe a superação do dualismo entre o natural e o social e anuncia em suas obras, como decorrência de sua visão de homem histórico, uma concepção ética, a qual implica na responsabilidade de construção de uma ordem social capaz de assegurar a todos os homens, independentemente da idade, um presente e um futuro dignos desse mesmo homem (Vygotsky, 1997).

Nessa perspectiva, o desenvolvimento é compreendido como a incorporação pelo homem dos componentes da cultura do meio social em que está inserido, ou seja, sua constituição se dá pela sua progressiva participação na trama da complexa rede de relações sociais em que desde o nascimento é envolvido.

A velhice humana não é uma fase natural do desenvolvimento, é uma construção social que tem suas repercussões na subjetividade e no desenvolvimento dos homens. É um momento significado, interpretado e construído pelos homens.

Não se trata, com a adoção dessa postura, de negar a existência de mudanças orgânicas decorrentes do processo de envelhecimento, mas sim de compreender que essas marcas constituem também a velhice como fenômeno social. Elas são significadas histórica e culturalmente e, por essa razão, deixam de ser exclusivamente um fato natural.

\section{A aprendizagem na velhice}

Foi a partir do reconhecimento do crescente número de idosos na Europa que, no final da década de 1960, na França, surgem várias propostas de serviços direcionados às pessoas idosas e, pela primeira vez, a discussão de questões relativas à aprendizagem na velhice ou maturidade ou às dificuldades de aprendizagem decorrentes das mudanças geradas pelo envelhecer.

As denominadas Universidades para a Terceira Idade (Unatis), logo no seu início, estavam interessadas em criar um espaço voltado quase que exclusivamente às atividades sociais, tendo como objetivo ocupar o tempo livre de seus integrantes. Contudo, em 1973, como 
escreve Peixoto (2000), os objetivos das Unatis francesas começam a se voltar também à construção de um conjunto de conhecimentos específicos para adaptar as estratégias didáticas de forma a garantir qualidade de ensino a todas as pessoas, favorecendo a participação cidadã dos idosos e a colocação dos conhecimentos historicamente produzidos a serviço de sua construção enquanto sujeito, em uma proposta conhecida como Educação Permanente (Cachioni \& Palma, 2000).

As ações pautadas em tais pressupostos críticos da educação do idoso buscam promover a tomada de consciência por parte dessas pessoas sobre seus direitos, sua qualidade de vida, suas formas de autorrealização e o papel social que podem assumir. Além dessas considerações, destacam-se na literatura algumas iniciativas, mesmo que escassas, de buscas de melhores caminhos e metodologias para a prática pedagógica com idosos.

Como sinalizam Cachioni \& Palma (idem), não se tratam de técnicas ou tecnologias de ensino definidas a priori, mas de um conjunto de facilitadores que levem em conta a especificidade desse período da vida e a heterogeneidade de experiências do envelhecer. Partindo do pressuposto de uma educação que se define como um processo humanizador e que visa à autonomia dos seus sujeitos, a metodologia deve ser ativa, participativa e interativa, permitindo que o idoso e o grupo em que está inserido descubram as próprias necessidades e sejam agentes de sua própria transformação.

Para finalizar, Goldman (1999) escreve que ensinar a população idosa tem suas peculiaridades, porém determinadas não só pelo padrão etário, mas também pela cultura, pela classe social, pelo nível de instrução, pelas condições de saúde, entre outras. Sendo assim, a educação, em qualquer idade, deve proporcionar aos educandos os meios mais adequados para que eles, por meio da apropriação de conhecimentos e habilidades construídas historicamente, desenvolvam ao máximo suas potencialidades.

Para que isso se efetive na educação do idoso, é necessário que os programas tenham uma concepção realista da velhice e não se instituam enquanto organizações de caráter substitutivo ou complemen- 
tar à educação dos alunos. Antes eles devem se configurar como um sistema com fundamentos, princípios e finalidades específicas não voltados ao assistencialismo e à tutela dos idosos.

Diante de tais apontamentos, pergunta-se como se constitui a demanda do alunado que procura um programa de formação continuada, mais especificamente em contextos universitários, na tentativa de buscar maiores conhecimentos acadêmicos, na fase denominada velhice.

Foi partindo desses questionamentos e do reconhecimento de que as Unatis podem efetivamente se constituir em espaços de lazer e de educação, nos quais seja possível refletir a respeito da velhice, de suas configurações sociais, que os objetivos de um estudo maior foram traçados. Entretanto, este texto, que decorre dessa pesquisa, se limitará a apresentar o perfil dos alunos da Unati investigada e descrever a avaliação que aqueles fazem de sua participação nas atividades. Com isso pretende-se demonstrar quais as características que compõem a demanda de alunos que procuram uma universidade tardiamente, bem como o que caracteriza um programa dessa natureza.

\section{Histórico e objetivos do programa}

O programa escolhido para a realização desta pesquisa foi uma Unati vinculada a uma instituição de Ensino Superior privada localizada em uma cidade do oeste paulista. A escolha pelo programa se deu em razão de sua sólida estrutura organizacional e do grande e diverso número de atividades oferecidas aos seus alunos.

A Unati investigada configura-se como um serviço prestado à comunidade e seu objetivo principal, segundo a descrição contida em sua proposta, é contribuir para a melhoria da qualidade de vida das pessoas adultas e idosas, oferecendo a elas oportunidade de desenvolver-se cultural e psicologicamente, ampliar redes de contato social e sua participação na sociedade.

O programa ainda tem como seus objetivos a convivência entre diferentes gerações em um contexto universitário e o desenvolvimen- 
to de estudos e pesquisas que contribuam para o conhecimento mais aprofundado do envelhecimento. É destinado a pessoas de ambos os gêneros, alfabetizadas, com cinquenta anos ou mais. Como se vincula a uma instituição privada, são cobrados dos alunos valores mensais e taxas de matrícula a cada semestre letivo. ${ }^{4}$

Os alunos, a cada novo semestre, têm à sua disposição diversas opções de atividades esportivas, recreativas, educativas e de cuidados com a saúde, planejadas e ministradas por trinta professores, entre eles docentes universitários, funcionários da universidade e alunos estagiários (sob orientação de um professor responsável). A participação nas atividades é voluntária, sendo condicionada apenas à existência de vagas no momento da matrícula. Somente uma das atividades tem caráter obrigatório a todos os participantes, pois se destina a ser um momento de confraternização entre os alunos e de discussão de assuntos relacionados à programação dos cursos e atividades.

As disciplinas regulares oferecidas aos 35 cursos de graduação da universidade são também abertas aos alunos da Unati, com exceção daquelas que exigem conhecimentos específicos em determinadas áreas de conhecimento como pré-requisitos para a matrícula (especialmente aquelas voltadas à área da saúde). Os cursos superiores mais procurados pelos alunos da Unati são Psicologia, Pedagogia, História, Filosofia e Letras.

\section{Quem são os alunos da Unati?}

Para que seja possível conhecer quem são os alunos da Unati, foi realizada a elaboração de um perfil dos matriculados a partir das informações sociodemográficas contidas nas fichas de inscrição dos alunos no ano de 2007 e primeiro semestre de 2008, disponibilizadas pela secretaria.

4 No ano em que foi realizada essa pesquisa, o valor correspondia a aproximadamente $8 \%$ do salário mínimo nacional, e a taxa de inscrição, a $2 \%$ desse mesmo referente. 
A análise dos dados demonstrou que em 2007, 240 pessoas se inscreveram no programa (195 no primeiro semestre e 45 no segundo). Dos alunos matriculados no primeiro semestre, 104 deles já estavam no programa desde o ano anterior e 91 eram alunos novatos, totalizando 195 alunos. Do número total de inscritos no segundo semestre (175), 130 já estavam matriculados no programa no período anterior. Nesse semestre o número de inscrições de novos alunos foi de 45 .

Em 2008, o índice de continuidade no programa foi um pouco maior que $50 \%$, sendo que 92 dos 175 alunos matriculados no ano anterior permaneceram no programa. $\mathrm{O}$ número de novas inscrições nesse semestre chegou a noventa.

Observando o número de alunos que se mantêm no programa por mais de um semestre letivo, tem-se que apenas no segundo semestre de 2007 o número ultrapassou a metade do número de novas inscrições. Esse é um dado que pode ser relevante para que se pense a respeito de possíveis insatisfações com relação às atividades oferecidas e que poderiam levar ao desligamento dos alunos.

A distribuição dos alunos por gênero no ano de 2007 apontou grande predominância de mulheres, dado este que coincide com os apontamentos realizados por diferentes autores da área do envelhecimento (Berquió, 1999; Peixoto, 2000; Sant'Anna, 2000; Toni, 2007). Do total de alunos no ano de 2007, 80,8\% são mulheres (194 dos 240 alunos).

De modo geral, a expectativa de vidas das mulheres supera a dos homens em razão de múltiplos fatores, como diferença de exposição às causas de risco de trabalho, de consumo de tabaco e álcool e de atitudes em relação a enfermidades e assistência médica (Veras \& Caldas, 2004). Outro fato de destaque refere-se à maior procura por programas de atenção a pessoas idosas por parte das mulheres, bem como por propostas voltadas aos cuidados com a saúde, realização de atividades físicas, entre outras.

Apesar da Unati investigada consistir em um programa destinado à população idosa, 40,4\% dos alunos estão abaixo dos sessenta anos, ou seja, não podem ser considerados pessoas idosas segundo 
os critérios da Organização Mundial de Saúde que definem essa faixa etária. Esses dados oferecem indicativos de que a Unati constitui-se, atualmente, em um programa voltado para atender uma grande população de adultos ( $65 \%$ do total) com idade até 65 anos e recém aposentada.

Comparando-se a distribuição dos alunos por idade e gênero, tem-se que aproximadamente metade das alunas (50,5\%) do programa encontra-se na faixa dos cinquenta aos sessenta anos. Nesse grupo encontram-se apenas $21,7 \%$ dos homens. No grupo dos alunos com idade entre 61 e setenta anos estão $52,2 \%$ das mulheres e $35,6 \%$ dos homens. As mulheres com mais de 71 anos representam $13,9 \%$, enquanto os homens, $26,1 \%$ desse total.

Pelos dados encontrados, assim como aponta Peixoto (2000), é possível verificar que os homens entram mais tarde do que as mulheres na Unati, o que se deve, provavelmente, ao efeito da diferença de idade para aposentadoria entre homens e mulheres. Do total de alunos matriculados no programa em 2007, mais da metade é casada (59,6\%). Em seguida, aparecem como mais numerosos os grupos dos viúvos, separados e solteiros, sendo esse último um grupo bastante pequeno (12 alunos). Dois participantes não responderam a essa pergunta.

Observando a distribuição dos alunos por gênero e idade, quanto ao estado civil é possível constatar a grande diferença entre porcentagens de homens e mulheres casados e viúvos. Mais de $80 \%$ dos homens matriculados na Unati são casados. Das mulheres, independentemente de faixa etária, $54,6 \%$ são casadas, enquanto $26,3 \%$ são viúvas. Apenas $6,5 \%$ dos homens matriculados são viúvos.

À medida que a idade avança, as diferenças entre os grupos ficam ainda maiores. Isso ocorre, segundo Veras (1994), devido ao maior período de vida das mulheres. Além de a mulher ter vida mais longa, normalmente, por fatores culturais, ela se casa mais jovem do que o homem. Esses dois fatores acabam por gerar as diferenças entre porcentagens de homens e mulheres viúvos.

Com relação à questão de moradia, 40,4\% residem com seus cônjuges. Em seguida, aparece o grupo de alunos que reside sozinho, 
com cônjuges e filhos, aqueles que moram apenas com os filhos e, por último, os que residem com seus pais. Dez alunos, ou $4,2 \%$ do total, responderam a essa questão dizendo residir em outras configurações familiares.

Comparando a situação de moradia por gênero e idade, observase novamente uma grande diferença entre homens e mulheres. Quase dois terços dos homens matriculados no programa vivem com suas esposas, enquanto $35 \%$ das mulheres responderam residir com seus cônjuges. Em todas as faixas etárias, a proporção de homens que residem com o cônjuge permanece maior que a observada entre as mulheres.

Já a porcentagem de homens e mulheres que residem com cônjuge e filhos não apresenta diferenças muito importantes. Esses números apenas decrescem com o aumento da faixa etária dos alunos, fato este explicado, provavelmente, em razão da saída de casa dos filhos e da constituição de novas famílias.

Os alunos do programa da Unati, em sua maioria, são aposentados e não mais exercem atividades remuneradas (68,8\%). Do total, $23,8 \%$ não são aposentados e 4,7\% responderam ser pensionistas, porém não informaram o exercício de outro trabalho remunerado. Sete alunos (ou 2,9\%) não responderam a essa questão.

Encontra-se uma maior porcentagem de mulheres que vivem com seus filhos do que homens vivendo nessa mesma condição. Como o número de mulheres viúvas é maior que o de homens, talvez, em razão da perda do cônjuge, as mulheres passem a residir com seus filhos ou ainda sozinhas. Apenas as mulheres responderam viver com seus pais, uma vez que esse grupo se constituiu majoritariamente por pessoas com idade inferior a sessenta anos (o que aumenta a probabilidade de terem pais vivos).

Há predominância de homens aposentados, se comparados à porcentagem de mulheres aposentadas. Esses dados devem-se, provavelmente, ao fato de muitas mulheres (especialmente as mais velhas) não terem exercido, ao longo da vida, trabalho remunerado oficialmente e que gerasse contribuição previdenciária. Como exemplo, dos homens com mais de 71 anos, 100\% são aposentados; das 
mulheres nessa mesma faixa etária, apenas $60 \%$ são aposentadas. Dentre o total geral de mulheres, $27,8 \%$ responderam ser pensionistas, enquanto apenas $6,5 \%$ dos homens encontram-se nessa mesma condição.

Entre as profissões exercidas antes da aposentadoria, o magistério ocupou a primeira posição. Em seguida, apareceram os grupos de alunos que não exerciam atividade remunerada antes da aposentadoria (compostos exclusivamente por mulheres), os comerciantes e pequenos empresários, os profissionais autônomos, os bancários, os funcionários públicos, os profissionais da área da saúde (médicos, enfermeiros, psicólogos) e o grupo composto por outras profissões. Cerca de $9 \%$ dos alunos não informaram, na ficha de inscrição, a atividade que exerciam.

É importante informar que os grupos compostos por professores, bancários, funcionários públicos e profissionais da área da saúde são totalmente formados por profissionais aposentados. Aqueles que responderam ainda exercer atividade remunerada ocupam cargos relacionados ao comércio ou a pequenas empresas e atividades autônomas.

Esse dado parece relevante na medida em que a participação em atividades da Unati exige dos alunos disponibilidade de tempo. Sendo assim, os alunos não aposentados possuem, mesmo ainda exercendo atividades remuneradas, possibilidade de flexibilização dos horários de trabalho.

A distribuição dos alunos em porcentagens com relação à renda familiar concentra-se na faixa entre dois e seis salários mínimos, o que corresponde a quase $40 \%$ do alunado. Em seguida, aparecem os grupos de alunos com rendimento mensal entre sete e dez salários e entre 11 e vinte salários mínimos. O número de alunos com renda inferior a um salário e superior a vinte salários é pouco significativo e representam, juntos, aproximadamente $10 \%$ do total.

A distribuição dos alunos com relação à renda familiar mensal apresenta diferenças quando analisada por meio das variáveis gênero e idade. Os homens apresentam os maiores rendimentos mensais. Quase 35\% deles estão na faixa de 11 e vinte salários. No grupo 
feminino, a maioria se concentra na faixa de dois e seis salários mí$\operatorname{nimos}(43,3 \%)$.

Esses resultados, além de indicarem a menor participação da mulher no exercício de atividades remuneradas, podem refletir a desvalorização do trabalho feminino e, por consequência, sua menor remuneração, se comparada àquela recebida por trabalhos realizados por homens.

Dos 240 alunos que realizaram matrícula no ano de 2007, 127 disseram possuir algum tipo de problema de saúde. A proporção entre homens e mulheres com relação à presença de problemas de saúde é bastante próxima (56,5\% dos homens e 52,1\% das mulheres disseram apresentam problemas de saúde). Com o avanço da idade, há o aumento da presença de problemas de saúde para homens e mulheres. Contudo, observa-se aumento maior no grupo feminino, o que se deve, como explica Veras (1994) e Peixoto (2000), à maior sobrevida das mulheres.

Entre os problemas de saúde mais citados pelos alunos, a hipertensão arterial ocupou o primeiro lugar. Apareceram também problemas como artrose, diabetes, osteoporose, cardiopatias diversas e a categoria outros problemas de saúde, a qual contemplava, entre alguns problemas de saúde citados, problemas psiquiátricos, metabólicos, neoplasmas malignos, alterações em níveis de colesterol e triglicerídeos no sangue. Cerca de 40\% dos alunos (ou 49 alunos) que responderam afirmativamente a essa questão disseram possuir, no mínimo, dois tipos de problemas de saúde.

\section{O que os alunos esperam da Unati?}

Para avaliar a satisfação dos alunos e os benefícios percebidos a partir da frequência no programa, e assim obter indicativos a respeito do que buscam os alunos idosos ao ingressarem em uma Unati, todos os alunos matriculados no período em que se deu a coleta de dados foram convidados a responderem à Escala de Expectativas em relação ao programa, instrumento elaborado por Neri \& Cachioni 
(1999), ${ }^{5}$ com o objetivo de conhecer em que grau a frequência à Unati atende às expectativas dos alunos e afeta a experiência do envelhecimento em relação ao bem-estar subjetivo e à autoimagem. As análises que se seguem foram realizadas a partir do cálculo da média aritmética dos valores atribuídos pelos alunos aos itens da escala.

Nessa etapa do estudo, participaram trinta alunos idosos dos 175 matriculados no segundo semestre de 2007. Àqueles que aceitaram participar do estudo foram apresentadas informações sobre o trabalho e sobre o caráter voluntário de sua participação, firmado por meio do Termo de Consentimento Livre e Esclarecido, com base na Lei 196/96. Dos participantes, 11 eram do gênero masculino, e 19, do feminino. A média de idade foi de 63,5 anos.

Percebeu-se que os alunos da Unati avaliaram de maneira muito similar os quatro primeiros itens da escala, que se referem à satisfação em frequentar as atividades. A ocupação do tempo livre apareceu como o item melhor avaliado (3,73 em uma escala de cinco pontos, com variação de 0 a 4), seguido pela busca de conhecimento, pela busca de contato social e pelo aperfeiçoamento pessoal.

Tabela 1 - Médias relativas à satisfação em frequentar uma Unati

Satisfação das Expectativas

1. Busca de conhecimento

2. Busca de contato social

3. Aperfeiçoamento pessoal

4. Ocupação do tempo livre
Média

$$
\begin{aligned}
& 3,67 \\
& 3,57 \\
& 3,53 \\
& 3,73
\end{aligned}
$$

5 Os vinte itens contidos no instrumento (escalas de cinco pontos de 0 a 4 - nada a muito), divididos em três áreas - expectativas, opiniões sobre bem-estar subjetivo e mudanças de autoimagem -, foram estabelecidos pelas autoras do instrumento de acordo com a literatura e com extensas pesquisas desenvolvidas pelo Núcleo de Estudos Avançados do Envelhecimento e Velhice da Universidade de Campinas (Unicamp). Mantiveram-se os mesmos itens do instrumento original, uma vez que, dessa forma, poderiam ser realizadas comparações com outras pesquisas. 
Segundo Peixoto (2000), há de se esperar que as pessoas, à medida que ficam mais velhas, busquem a realização pessoal e a autossatisfação, especialmente depois da aposentadoria. Citando Debert (1999), é como que se finalmente essas pessoas participantes de programas como as Unatis, em sua maioria mulheres, tivessem conquistado o direito ao roless role, que muitos gerontólogos e pessoas mais novas veem como o drama da velhice e que para os idosos é um privilégio que deve ser vivido com intensidade depois de uma vida tão cheia de obrigações para com os outros.

Para os alunos do programa, a expressão "ocupação do tempo livre" parece extrapolar a noção inicial de ociosidade e inatividade, talvez devido ao modo como estas sejam compreendidas pelos mais jovens. Segundo as respostas dos alunos, pode-se inferir que a participação na Unati reflete um momento de escolhas por atividades prazerosas e que condensam em si também objetivos educativos, de socialização e de desenvolvimento pessoal.

Quanto ao grau em que frequentar a Unati afeta o bem-estar subjetivo dos alunos, observou-se que na opinião destes, o principal efeito estaria relacionado às atitudes em relação aos mais jovens, ou seja, a frequência à Unati estaria melhorando a forma como os idosos se relacionam com pessoas mais novas. Em seguida, aparecem as melhorias no grau e na forma como se relacionam com pessoas idosas, com os familiares, percebem-se satisfeitos com eles próprios e enfrentam a questão da morte.

O item que recebeu os menores escores foi a melhoria na expectativa de vida, sendo este o único item a apresentar escore médio inferior ou igual a 3. As médias obtidas com relação à avaliação dos alunos da mudança de autoimagem gerada pela frequência na Unati apresentaram valores bastante elevados. 
Tabela 2 - Médias referentes ao grau em que frequentar a Unati afeta o bem-estar subjetivo dos participantes

\begin{tabular}{cc}
\hline Satisfação das Expectativas & Média \\
\hline 1. Atitudes em relação ao idoso & 3,57 \\
2. Atitudes em relação ao jovem & 3,77 \\
3. Atividade & 3,2 \\
4. Capacidade física & 3,1 \\
5. Cognição & 3,47 \\
6. Enfrentamento da morte & 3,5 \\
7. Expectativas de futuro & 2,36 \\
8. Produtividade & 3,26 \\
9. Relações familiares & 3,53 \\
10. Satisfação & 3,5 \\
11. Saúde física & 3,33 \\
\hline
\end{tabular}

Tabela 3 - Médias referentes ao grau em que frequentar a Unati afeta a autoimagem dos participantes

\begin{tabular}{cc}
\hline Satisfação das Expectativas & Média \\
\hline 1. Aceitação & 3,56 \\
2. Valorização & 3,54 \\
3. Respeito & 3,56 \\
4. Credibilidade & 3,48 \\
5. Confiança na capacidade & 3,71 \\
\hline
\end{tabular}

Os resultados desse instrumento indicam que, para os alunos, a frequência no programa alterou de forma importante a percepção sobre suas capacidades e habilidades cognitivas e sociais, a forma como se relacionam com outras pessoas e a forma como são percebidos por elas, uma vez que todas as médias das respostas estiveram acima do valor 3 na escala de cinco pontos $(0$ a 4$)$. 
Para esse grupo, frequentar a Unati contribui, principalmente, para a melhoria de suas relações sociais, uma vez que os itens que receberam avaliações mais positivas foram aqueles que indicavam melhorias nas atitudes em relação aos jovens, aos idosos e nos relacionamentos familiares. Quando os alunos avaliaram as mudanças em sua autoimagem, disseram que depois de frequentar a Unati perceberam-se mais confiantes em suas capacidades, mais aceitos, respeitados e valorizados.

O item expectativas em relação ao futuro, na avaliação dos alunos, foi aquele que obteve os menores escores, o que pode indicar que apesar da frequência no programa trazer benefícios à vida dos alunos, da forma como está organizado não produz alterações no planejamento e na expectativas com relação ao futuro de seus participantes.

Em síntese, a Unati parece contribuir para a melhoria da imagem da pessoa idosa na sociedade, tornando mais visíveis capacidades que, a princípio, são tomadas como deficitárias na velhice e indicam concepções equivocadas do queé envelhecer. Além disso, para os alunos, a frequência à Unati parece favorecer as relações sociais entre aqueles e pessoas de diferentes grupos etários, o que demonstra a consecução de um dos grandes objetivos de programas dessa natureza: a integração e a convivência intergeracional.

Além disso, os dados que indicaram uma avaliação mais positiva dos relacionamentos entre os alunos e seus familiares trazem mais uma contribuição à validação da hipótese de que as Unatis constituem-se como espaços educativos intergeracionais.

A família é o local primeiro em que se dão as relações sociais entre pessoas de diferentes faixas etárias (Ferrigno, 2003). Aprendendo a conviver com outras pessoas, a serem ouvidos por pessoas mais novas e a ouvir o que estas podem lhe ensinar, é possível que a convivência familiar dos alunos com seus esposos, filhos e netos seja também melhorada. Outro aspecto que contribui para um melhor relacionamento familiar é o fato de os idosos, assim como acontece nas Unatis, serem também, dentro do contexto do seu lar, mais respeitados e percebidos como indivíduos capazes de fazer amigos e desenvolverem atividades valorizadas socialmente. 
Ainda segundo Ferrigno (idem), essas reflexões sobre os benefícios da intergeracionalidade se apoiam na certeza de que a convivência e o compartilhamento de experiências de velhos e moços, ao combater o preconceito etário, pode efetivamente contribuir para a melhoria da qualidade de vida dessas pessoas não somente dentro dos espaços educativos, mas também podem contribuir para a edificação de uma sociedade mais justa, tolerante, democrática e solidária.

Com relação à contraposição existente desde o surgimento das primeiras propostas educativas para idosos entre lazer e educação, os dados descritos favorecem a compreensão de que nesses espaços é preciso agregar tais propostas a planejamentos que sejam capazes de, por meio de atividades prazerosas, apontar para uma perspectiva de avanço social e para a emergência de ações autônomas resultantes de processos reflexivos que atendam às necessidades e expectativas dos idosos (Freitas et al., 2002).

A participação dos alunos no planejamento de tais atividades, nesse sentido, é essencial para que elas sejam pertinentes aos seus anseios e ultrapassem a condição de simples ocupação do tempo livre. Compreende-se que, se bem definidas e planejadas, as iniciativas das Unatis podem romper com os estereótipos e preconceitos associados ao período do envelhecimento humano ou mesmo à sua frequente negação e extrema valorização do "bem envelhecer" e do "manter-se jovem, apesar da idade".

Por fim, é preciso ainda considerar neste trabalho o que Rifiotis (2007) chama de desafio ético e teórico das ciências do envelhecimento e das propostas de serviços direcionados ao idoso. Para o autor, o idoso não pode ser considerado um objeto do conhecimento produzido a respeito das questões da velhice e do envelhecimento, mas necessariamente o sujeito dessa produção. Nesse sentido, ouvir o idoso e considerar seu discurso é imprescindível ao avanço das ciências envolvidas em discussões como a que se apresenta.

Por meio dos dados apresentados neste capítulo a respeito do perfil dos alunos da Unati, buscou-se oferecer subsídios à compreensão de outras possíveis investigações na área da educação do idoso, uma vez que, apoiando-se nos argumentos de Sant'Anna (2000), não 
existem generalizações para a velhice. A cada novo estudo, faz-se necessário conhecer o universo particular dos idosos e evitar, com isso, equívocos ou transposições indevidas.

\section{Referências bibliográficas}

BERQUIÓ, E. Considerações sobre o envelhecimento da população no Brasil. In: NERI, A. L.: DEBERT. G. G. (Orgs.) Velhice e sociedade. São Paulo: Papirus, 1999, p.11-39.

CACHIONI, M; PALMA, L. S. A educação permanente: perspectiva para o trabalho com o adulto maduro e o idoso. In: FREITAS et al. Tratado de geriatria e gerontologia. Rio de Janeiro: Guanabara Koogan, 2002, p.1102-09.

DEBERT, G. G. A construção da velhice: família, classe social e etnicidade. In; NERI, A. L.; DEBERT, G. G. (Orgs.). Velhice e sociedade. São Paulo: Papirus, 1999, p.41-65.

FERRIGNO, J. C. Co-educação entre gerações. São Paulo: SESC, 2003.

FREITAS et al. Tratado de geriatria e gerontologia. Rio de Janeiro: Guanabara Koogan, 2002.

GOLDMAN, S. N. Envelhecimento e educação permanente: uma pedagogia específica do idoso? Revista Kairós, São Paulo, v.2, p.2743, 1999.

NERI, A. L. Qualidade de vida no adulto maduro: interpretações teóricas e evidências de pesquisa. In: NERI, A. L. Qualidade de vida e idade madura. Campinas: Papirus, 1993, p.9-55.

; CACHIONI, M. Velhice bem-sucedida e educação. In: NERI, A. L; DEBERT, G. G. (Orgs.). Velhice e sociedade. Campinas: Papirus, 1999, p.113-40.

(Org). Maturidade e velhice. Campinas: Papirus, 2001.

PAPALÉO NETTO, M.; BORGONOVI, N. Biologia e teorias do envelhecimento. In: PAPALEO NETTO, M. (Org). Gerontologia: a velhice e o envelhecimento em visão globalizada. São Paulo: Atheneu, 2002, p.501-16.

PASKULIN, L. M. G.; VIANA, L. Perfil sociodemográfico e condições de saúde autorreferidas de idosos. Revista de Saúde Pública/ Journal of Public Health, v.41, p.757-68, 2007. 
PEIXOTO, C. De volta às aulas ou de como ser estudante aos 60 anos. In: NERI, A. L.; FREIRE, S. A. (Orgs). E por falar em boa velhice. Campinas: Papirus, 2000, p.42-74.

RIFIOTIS, T. O idoso e a sociedade moderna: desafios da gerontologia. Revista Pro-Posições. Campinas, v.18, n.1, p.137-51. Disponível em: $<$ http $>$ ://http://mail.fae.unicamp.br/ proposicoes/textos/52-artigos-rifiotist.pdf $>$. Acesso em: 14 mai. 2008.

SANT'ANNA, M. J. G. UNATI, a velhice que se aprende na escola: um perfil de seus usuários. In: NERI, A. L.; FREIRE, S. A. (Orgs). E por falar em boa velhice. Campinas: Papirus, 2000, p.75-102.

TONI, I. M. A realidade brasileira das IES: perfil, expectativas e caracterização dos alunos das UNATIS. In: Fórum Nacional de Coordenadores de Projetos da Terceira Idade de Instituições de Ensino Superior e IX Encontro Nacinal de Estudantes da Terceira Idade de Instituições de Ensino Superior. 2007. Disponível em: <http:// www.ucs.br/ucs/extensao/unti/evento/download_palestr as >. Acesso em: 07 jun. 2008

; CALDAS, C. P. Promovendo a saúde e a cidadania do idoso: o movimento das universidades da terceira idade. Ciência E Saúde Coletiva, Rio de Janeiro, v.9, n.2, 2004.

VYGOTSKY, L. S. Fundamentos da defectologia. Madrid: Visor, 1997 


\section{4 \\ AVALIAÇÃo E INTERVENÇÃo COM CRIANÇAS EM CONDIÇÃO DE SOBREPESO E OBESIDADE}

Lucinéia Crepaldi de Mello ${ }^{1}$ Sandro Caramaschi ${ }^{2}$

\section{Introdução}

\section{Obesidade infantil}

A obesidade é um distúrbio complexo, com origens ambientais, genéticas e de desenvolvimento e com consequências médicas, psicossociais e econômicas (Fisberg, 2005). Segundo estudos de Kaufman (1999), o Brasil tinha, na época, cerca de três milhões de crianças com idade inferior a dez anos sofrendo de obesidade. A ocorrência de tal distúrbio na infância e na adolescência aumenta a possibilidade de sua manutenção na vida adulta, conforme afirmação de Fisberg (2005).

Vários autores relatam características em obesos como dependência, agressividade mal elaborada e sentimento de inferioridade para competir com indivíduos de seu meio, o que provavelmente vem a desfavorecer a ambição intelectual como foco de interesse pes-

1 Programa de Pós-Graduação em Psicologia do Desenvolvimento e Aprendizagem da Unesp - Bauru.

2 Idem. 
soal, de acordo com Campos \& Fisberg (2005), que consideram que essas características são associadas ao comportamento mais lento e mais primitivo do indivíduo obeso.

O tratamento da obesidade deve incluir, conforme Fisberg (2005), três condições básicas, as quais consistem em dieta balanceada, exercícios físicos controlados e apoio emocional.

\section{Aspectos socioemocionais}

Andrade (1995) verificou que de 134 crianças pesquisadas, 76,8\% apresentam razões emocionais importantes associadas ao surgimento e à evolução da obesidade. Ele acredita que um alto nível de ansiedade pode influenciar na gênese da obesidade, colaborando para a ocultação de conflitos internos, afetivos e relacionados.

Campos (2005) afirma que crianças obesas apresentam algumas características psicológicas como dificuldade de lidar com experiências de forma simbólica, de adiar satisfações, de obter prazer na relações sociais, de lidar com a sexualidade, além de baixa autoestima e de dependência materna.

A palavra bullying é traduzida como "valentão", "tirano", e como verbo é traduzida como "brutalizar", "tiranizar", "amedrontar". A definição do bullying é compreendida como um subconjunto de comportamentos agressivos, sendo caracterizado por sua natureza repetitiva e por desequilíbrio de poder. O desequilíbrio de poder se dá pelo fato de que a vítima não consegue se defender com facilidade devido a inúmeros fatores, tais como: por ser de menor estatura ou força física, por estar em minoria, por apresentar pouca habilidade de defesa e pela falta de assertividade e pouca flexibilidade psicológica perante o autor ou autores dos ataques (Fante, 2005).

Visto o caráter nefasto do fenômeno bullying, acredita-se na importância de preveni-lo e de promover intervenções eficazes para suprimi-lo e combatê-lo. Segundo Fante (idem), a prevenção do bullying deve começar pela capacitação dos profissionais de educação, a fim de que saibam identificar, distinguir e diagnosticar o fenômeno e conhecer estratégias de intervenção e prevenção. 
Se a violência é um comportamento que se aprende nas interações sociais, também existem maneiras de ensinar comportamentos não violentos para que se possa lidar com as frustrações e com a raiva. É preciso ensinar habilidades para que os conflitos interpessoais possam ser solucionados por meios pacíficos (idem, ibidem). O diálogo, o respeito e as relações de cooperação precisam ser valorizados e assumidos por todos os envolvidos no processo educacional.

\section{Habilidades sociais}

Del Prette \& Del Prette (1996) consideram que comportamentos de habilidades sociais têm sido reconhecidos em diversas áreas das ciências humanas como fundamentais para a manutenção de interações sociais satisfatórias. Todavia, comportamentos socialmente inadequados podem resultar em baixa qualidade das interações, em baixo rendimento escolar, em perda de oportunidades profissionais e em baixa satisfação pessoal.

Há uma série de classes de respostas citadas por Caballo (1996) como componentes das habilidades sociais. Dentre estas destacamse: iniciar e manter conversações; falar em público; expressar amor, agrado e afeto; defender os próprios direitos; pedir favores; recusar pedidos; fazer obrigações; aceitar elogios; expressar opiniões pessoais, inclusive discordantes; expressar, com justificativa, incômodo, desagrado ou enfado; desculpar-se ou admitir ignorância; solicitar mudança no comportamento do outro e enfrentar críticas.

Del Prette \& Del Prette (2002, 2005), Caballo (2003) e Falcone (1995) consideram a assertividade como um dos comportamentos socialmente habilidosos, entre vários outros. A assertividade envolve a afirmação dos próprios direitos e a expressão dos pensamentos, sentimentos e crenças de maneira direta, honesta e apropriada, de modo que não viole o direito das outras pessoas. Para Del Prette \& Del Prette (2006), há alguns conceitos importantes para a compreensão das definições de reações habilidosas e não habilidosas. Dentre estas se destacam: desempenho social, habilidades sociais e competência social. 
Diante dessas considerações, o presente trabalho objetivou realizar avaliação e intervenção psicossocial com crianças em condições de sobrepeso e obesidade.

\section{Método}

\section{Participantes}

O estudo foi conduzido com 15 crianças, sendo seis do sexo masculino e nove do sexo feminino, com idades variando entre nove anos e oito meses e 11 anos e quatro meses e escolaridade entre $3^{\mathrm{a}}$ e $5^{\mathrm{a}}$ séries do $1^{\circ}$ grau. Das 15 crianças participantes, 12 estavam matriculadas em escola pública, e três, em escola particular.

Foi constituído um grupo com sete crianças, sendo dois meninos e cinco meninas. Das crianças, uma tinha 11 anos, cinco tinham dez anos e uma tinha nove anos de idade. O outro grupo foi formado por oito crianças, sendo quatro meninos e quatro meninas. Destas, três tinham 11 anos, uma tinha dez anos, três tinham nove anos e uma tinha oito anos de idade.

Foram selecionadas crianças em tal faixa etária em virtude do caráter instrucional do trabalho proposto (sendo indicado para crianças já alfabetizadas) e da exigência de certa independência pessoal (para virem e voltarem sozinhas, se necessário, ou precisarem esperar por um responsável na sala de espera após o término dos encontros).

\section{Local}

A pesquisa foi realizada no centro de saúde, em uma cidade do interior do estado de São Paulo. A avaliação inicial e final das crianças e dos pais foi feita em uma sala que media aproximadamente três metros de comprimento por dois metros de largura. As sessões grupais com as crianças se deram em outra sala do centro de saúde, a qual media aproximadamente cinco metros de comprimento por três 
metros e meio de largura. Ambas eram iluminadas naturalmente através de janelas e artificialmente com luminárias.

\section{Materiais e instrumentos}

Foram utilizados para o trabalho os seguintes materiais: lápis preto $\mathrm{n}^{\circ} 2$, lápis de cor, borracha, caneta, cartolinas, pincéis atômicos, cartazes ilustrados, canetas hidrocor, CD-rom, computador, multimídia, alimentos em plástico, jogo "Brincando com as expressões", bexigas, folhas impressas com tarefas delimitadas, bola, espelho, fichas coloridas de papel, revistas, tesouras, cola, giz, lousa, alimentos, pratos, talheres, palitos, máquina fotográfica, fita adesiva, rádio, CDs de músicas, colchonetes, papéis-dobradura e balança.

Os instrumentos usados na pesquisa foram: (a) roteiro de entrevista inicial semiestruturada realizada com as crianças; (b) roteiro de entrevista final semiestruturada realizada com as crianças; e (c) Sistema Multimídia de Habilidades Sociais de Crianças (SMHSC) (Del Prette \& Del Prette, 2005).

A entrevista inicial com as crianças consistia em questões abertas, elaboradas pela pesquisadora, objetivando colher dados a respeito da convivência das crianças com os colegas na escola, da ocorrência do bullying, das atitudes dos professores diante do bullying, dos sentimentos e reações infantis na condição de vítima do bullying, das experiências como autores do bullying, da avaliação pessoal da condição de sobrepeso ou obesidade e da opinião sobre causas relacionadas à obesidade.

O Sistema Multimídia de Habilidades Sociais de Crianças (SMHSC) - Del Prette \& Del Prette consiste em material para avaliação de habilidades sociais, o qual também pode ser utilizado como instrucional em programas educativos ou terapêuticos para a promoção de competência social infantil em faixa etária de sete a 12 anos de idade. Foi utilizada na pesquisa a versão impressa desse instrumento de autoavaliação infantil. 
A entrevista final com as crianças consistia em questões abertas, elaboradas pela pesquisadora, visando levantar informações a respeito das mudanças de vida ocorridas, da convivência com colegas, da vitimização e reações diante do bullying e da autoimagem após a participação das crianças no Programa de Atenção a Crianças com Excesso de Peso (Pacep).

\section{Procedimentos de coleta de dados}

Antes do início da coleta dos dados, a pesquisadora fez contato com a coordenadora do setor de saúde do município e questionou-a sobre seu interesse em que a pesquisa fosse realizada no centro de saúde II. Obtendo resposta positiva sobre o interesse, foram explicitados os passos da pesquisa.

A partir disso, a pesquisadora conversou com as atendentes da recepção do centro de saúde e solicitou-lhes que divulgassem (verbalmente aos pais que procurassem a clínica pediátrica) o trabalho a ser realizado com crianças em condições de sobrepeso ou obesidade. O trabalho também foi divulgado em uma escola municipal e em duas particulares escolhidas aleatoriamente.

O trabalho grupal foi coordenado por uma psicóloga (pesquisadora) e contou com a participação de uma nutricionista, um professor de Educação Física e dois funcionários do centro de saúde. Das sessões propostas, nove foram com as crianças, e uma (a última), com os pais.

A seguir, os planos de cada sessão (objetivos e métodos):

Programa de Atenção a Crianças com Excesso de Peso (Pacep) Sessão $\mathbf{n}^{\circ} 01$

Objetivos: (1) Apresentação; (2) levantamento de expectativas, (3) estabelecimento de regras de convivência, (4) integração entre os participantes.

Método: (1) Dinâmica de grupo e conversa direcionada. 


\section{Sessão $\mathrm{n}^{\circ} 02$}

Objetivo: (1) Obter informações sobre questões nutricionais básicas, a fim de orientar-se quanto aos hábitos alimentares, e fazer o levantamento das preferências alimentares.

Método: (1) Exposição; (2) ilustração; (3) exercício prático.

Sessão ${ }^{\circ} 03$

Objetivos: (1) Retomar regras de convivência e conteúdos da sessão anterior; (2) repensar e reorganizar hábitos alimentares, considerando-se tipos de alimentos consumidos, horário e local das refeições; ser capaz de assumir tarefas propostas na sessão.

Método: (1) Interação verbal; (2) dinâmica de grupo; (3) automonitoramento; (4) exposição verbal.

\section{Sessão n $^{\circ} 04$}

Objetivos: (1) Ser capaz de identificar os próprios sentimentos e expô-los; (2) promover a integração grupal.

Método: (1) Interação verbal; (2) dinâmica de grupo; (3) jogo.

Sessão $\mathrm{n}^{\circ} 05$

Objetivos: (1) Propiciar-lhes condições para autoavaliação referente à imagem corporal e motivá-los à autoaceitação; (2) oportunizar a expressão dos sentimentos; (3) trabalhar dicas alimentares saudáveis.

Método: (1) Dinâmica de grupo; (2) conversa direcionada; (3) livre expressão verbal.

Sessão ${ }^{\circ} 06$

Objetivos: (1) Reconhecer as diferenças pessoais e a qualidade de ser especial como ser humano; (2) identificar o que os tornam pessoas especiais; oportunizar a aquisição do hábito de ingerir frutas em substituição a doces, levando-se em consideração os objetivos do grupo de manter a qualidade de vida; (3) conhecer o paladar de frutas ainda não experimentadas.

Método: (1) Dinâmica de grupo; (2) conversa direcionada; (3) alimentação coletiva.

Sessão n ${ }^{\circ} 07$

Objetivos: (1) Desenvolver habilidades sociais relativas ao enfrentamento do fenômeno bullying no contexto social; (2) promover a 
integração grupal para o fortalecimento do vínculo de amizade entre os participantes; (3) motivá-los ao consumo regular de alimentos saudáveis e pouco calóricos em substituição aos pouco nutritivos e de alto valor calórico; (4) motivá-los à prática de atividades físicas regularmente.

Método: (1) Dramatização baseada na técnica da Modelação, de Bandura (1986); (2) montagem de história em grupo; (3) refeição coletiva; (4) conversa direcionada e livre.

\section{Sessão $\mathbf{n}^{\circ} 08$}

Objetivos: (1) Recordar aspectos sobre habilidades sociais trabalhados na sessão anterior; (2) abordar maneiras "assertivas" de expressar nossos sentimentos; (3) conversar sobre a importância de cultivar amizades; (4) trabalhar com fins a desenvolver o autocontrole com relaxamento.

Método: (1) Dinâmica de grupo; (2) técnica de relaxamento; (3) conversa direcionada.

\section{Sessão n ${ }^{\circ} 09$}

Objetivos: (1) Realizar, com as crianças, o levantamento dos aspectos positivos e negativos dos encontros; (2) analisar os progressos obtidos, investigando mudanças de vida quanto a hábitos relativos à alimentação, prática das atividades físicas, pensamentos e atitudes em casa e na escola; (3) propiciar ambiente para confraternização; (4) criar iniciativa de preparação do próprio alimento ou de buscar receitas favoráveis à manutenção da qualidade de vida e que evitem o ganho de peso; (5) fazer a pesagem das crianças, a premiação e a entrega dos certificados.

Método: (1) Dinâmica de grupo; (2) discussão dirigida; (3) tarefa em grupo.

\section{Sessão $\mathbf{n}^{\circ} 10$}

Objetivos: (1) Conversar com os pais sobre o que foi abordado no programa (apanhado geral); (2) inserir a temática da obesidade infantil quanto a aspectos psicológicos, nutricionais e físicos.

Método: (1) Palestra. 


\section{Análise dos dados}

Os dados da pesquisa foram analisados por meio das abordagens quantitativa e qualitativa. As respostas às quatro entrevistas aplicadas foram registradas por escrito. Para a análise do conteúdo destas, as respostas foram inseridas em categorias preestabelecidas e avaliadas em porcentagem.

Os dados foram categorizados em função dos objetivos propostos para o programa e analisados por meio do relato verbal dos participantes e do desempenho nas tarefas de casa propostas nas sessões.

\section{Resultados e discussão}

Os resultados foram apresentados segundo a sequência da coleta de dados e divididos em seções de acordo com as atividades desenvolvidas.

\section{Análise dos dados na entrevista inicial e final com as crianças}

Para a análise dos dados da entrevista inicial foram utilizadas as seguintes categorias: predileção por colegas, ocorrência do bullying, atitudes da professora diante do bullying, sentimentos e reações das vítimas do bullying, experiências como autores do bullying, avaliação pessoal diante da situação de estar acima do peso e avaliação das causas da obesidade.

A primeira categoria revela que a predileção por certos colegas é determinada, em geral, pela boa receptividade deles, pela identificação na maneira de pensar, pela proximidade física (moradia) e pela iniciativa de brincar. Já os colegas preteridos, assim o são por motivos como: comportamento agressivo verbal e físico; de transgressão às regras impostas na escola, como falar palavrões, colocar apelidos; por desprezo às brincadeiras; e por comportamento de competição sexual (disputa por paquera). 
Quanto à ocorrência do bullying no contexto escolar (terceira categoria), 73\% afirmaram que o fenômeno ocorre envolvendo, no geral, condutas como apelidar, pegar objetos alheios e atirá-los no ventilador, fazer piadinhas, puxar os cabelos.

As atitudes da professora diante da ocorrência do bullying (quarta categoria) foram registradas como sendo advertência, risos, ameaça de levar os autores do bullying à diretoria, pedido de contenção das ações agressivas, colocação de apelidos, intervenção verbal e expressando que não é necessário fazerem o que estão fazendo para chamarem a atenção dos colegas.

Fante (2005) aborda que o bullying ocorre, com maior ou menor incidência, em todas as escolas do mundo, independente das características culturais, econômicas e sociais dos alunos, e enfatiza o despreparo dos educadores em geral para lidar com esse fenômeno de modo a colaborar para sua supressão ou erradicação, como observado no presente estudo.

A categoria de análise referente a sentimentos e reações das vítimas do bullying mostrou que as crianças relataram sentir-se bravas, tristes, iradas, constrangidas, chateadas, deprimidas ou indiferentes. Suas reações diante do bullying foram registradas como sendo: ficar quietas tentando expressar indiferença, sair de perto no momento da ocorrência, serem agressivas fisicamente, fingir não escutar as provocações, apelidar também.

Essas constatações estão de acordo com o que Lopes Neto \& Saavedra (2003) e Fante (2005) discutem a respeito das consequências das situações traumatizantes vivenciadas pelas vítimas do bullying, que quando não superadas, podem gerar baixa autoestima, baixo rendimento escolar, dificuldades de relacionamento, comportamentos agressivos, entre outros. Fante (2005) alerta para a gravidade do fenômeno bullying, visto o seu poder desencadeador de transtornos psíquicos e até de tragédia social (motivada por comportamentos de vingança das vítimas).

Quanto à questão da autoria do bullying, a entrevista com as crianças revela que a minoria (26\%) relatou experiência como autores de bullying com os colegas na escola. 
Na categoria de análise relativa à avaliação pessoal diante da situação de estar acima do peso, a maioria (66\%) considerou a existência de desvantagens devido a essa condição, sendo estas: a condição de serem alvo de apelidos, a rejeição social, as brincadeirinhas pejorativas, o cansaço físico, a vergonha do próprio corpo e a dificuldade para encontrar roupas que lhes sirvam.

Esses dados corroboram as afirmações de Lemes (2005) sobre a discriminação social de que as crianças obesas são vítimas, o que pode gerar fobia social, insegurança, timidez, sentimentos depressivos e autoimagem negativa.

$\mathrm{Na}$ avaliação das causas da obesidade, a maior parte das crianças atribuiu a condição de estar acima do peso ao fato de comerem em demasia (86\%), algumas especificando os tipos de alimentos calóricos como fritura, chocolate e doces em geral. Das crianças, $6 \%$ atribuíram a condição de excesso de peso à ansiedade, e 6\%, a doenças, sem especificá-las.

\section{Sistema Multimídia de Habilidades Sociais de Crianças (SMHSC)}

Observou-se nos resultados que todas as crianças avaliadas apresentaram predominância das respostas consideradas habilidosas, exceto C1, que apresentou empate entre as respostas habilidosas e as não habilidosas passivas.

A porcentagem de respostas não habilidosas ativas foi de $0 \%$ para todas as crianças avaliadas, exceto para C1, que apresentou $14 \%$ destas. A porcentagem de respostas não habilidosas passivas variou entre $0 \%$ e 43\%; de habilidosas, entre $43 \%$ e $100 \%$; e de não habilidosas ativas, entre $0 \%$ e $43 \%$ (Tabela 1 ).

Caballo (1996) considera, por exemplo, que expressar desagrado, incômodo ou enfado, pedir favores, recusar pedidos, desculparse ou admitir ignorância são respostas componentes das habilidades sociais. 
Tabela 1 - Porcentagem das reações infantis diante das habilidades avaliadas pelos testes do SMHSC em 17 categorias. Reações das crianças em cada categoria de habilidade avaliadas. NHP (não habilidosas passivas), H (habilidosas) e NHA (não habilidosas ativas)

NHP $\quad \mathrm{H} \quad$ NHA

1 - Juntar-se a grupo de brincadeira.

$0 \% \quad 100 \% \quad 0 \%$

2- Recusar pedido de colega.

$0 \% \quad 93 \% \quad 7 \%$

3 - Expressar desagrado.

$60 \%$

$33 \% \quad 7 \%$

4- Pedir ajuda ao colega em classe.

$7 \%$

$93 \% \quad 0 \%$

5 - Pedir mudança de comportamento.

$27 \%$

$73 \%$

$0 \%$

6- Pedir desculpas.

$0 \% \quad 100 \% \quad 0 \%$

7 - Demonstrar espírito esportivo.

$0 \% \quad 100 \%$

$0 \%$

8- Medir conflitos entre colegas.

$7 \%$

$93 \%$

$0 \%$

9- Negociar/convencer.

$7 \%$

$93 \%$

$0 \%$

10- Oferecer ajuda.

$0 \%$

11 - Propor nova brincadeira.

$7 \%$

$100 \%$

$0 \%$

12- Perguntar (questionar).

$33 \%$

$93 \%$

$0 \%$

13 - Responder perguntas à professora.

$60 \% \quad 7 \%$

14- Fazer perguntas à professora.

$27 \%$

$100 \%$

$0 \%$

15- Aceitar gozações.

$13 \%$

$73 \%$

$0 \%$

16- Agradecer um elogio.

$13 \%$

$87 \% \quad 0 \%$

17 - Resistir à pressão do grupo.

$20 \%$

$87 \% \quad 0 \%$

$80 \% \quad 0 \%$

Del Prette \& Del Prette (2002) e Caballo (2003) afirmam que indivíduos assertivos expressam seus sentimentos, opiniões, necessidades, interesses e direitos pessoais com honestidade, responsabilidade e diretividade, sem atitudes de humilhação ou dominação do outro.

A passividade na expressão de desagrado pessoal, por exemplo, pode estar relacionada à necessidade que muitas crianças obesas têm, segundo Lemes (2005), de agradar aos outros a fim de serem aceitas nos grupos onde convivem, os quais, em geral, têm atitudes de exclusão e preconceito. 
Por outro lado, a agressividade, por exemplo, para a expressão de desagrado e para a recusa de pedido, pode refletir o desejo e a expressão de vingança dessas crianças diante do bullying. As práticas de vingança e as dificuldades de relacionamento podem ser consequência da não superação dos traumas sofridos pelas vítimas do bullying, conforme explicitam Lopes Neto \& Saavedra (2003).

\section{Programa de Atenção a Crianças com Excesso de Peso (Pacep)}

Os resultados do Pacep foram anotados e analisados com base em categorias representativas, a saber: frequência dos participantes às sessões, qualidade de vida, habilidades sociais, bullying e autoestima. Tais categorias de análise basearam-se nos objetivos propostos para o desenvolvimento do programa.

A média da frequência dos participantes ao programa (o qual totalizou dez sessões) foi de aproximadamente $86 \%$ às sessões do Grupo I e de 73\% do Grupo II.

Com relação ao estresse e às habilidades sociais, observou-se que todas as crianças mostraram dar importância significativa a atos de colegas, autores do bullying, os quais costumam colocar apelidos e fazer gozações, enfatizando com chacotas a condição de obesidade. Todas as crianças relataram, ao longo das sessões, emoções como ira e tristeza perante a situação abordada, a qual parecia acontecer frequentemente.

Algumas crianças reagiam de maneira também agressiva (física ou verbal) e percebem benefícios apenas temporários, mas não em longo prazo.

De maneira geral, os participantes revelaram baixa autoestima, enfatizando as características físicas típicas da condição de sobrepeso ou obesidade, as quais são consideradas feias por eles. Grande parte deles relatou incômodo pelo volume excessivo do abdômen e das pernas, por exemplo. A maioria pareceu não gostar de se olhar 
no espelho, demonstrando insatisfação com o corpo. Campos (1993) comenta que a baixa autoestima é uma característica psicológica comum em crianças obesas.

Sanches \& Escribano (1999) definem o autoconceito como a atitude valorativa que um indivíduo tem sobre si mesmo, sobre sua própria pessoa. $\mathrm{O}$ autoconceito desempenha papel importante para a saúde mental dos indivíduos e para seus relacionamentos (consigo mesmo e com os demais).

De modo geral, os participantes apresentaram-se motivados e empenhados na realização das atividades propostas nas sessões. Procurou-se estabelecer, no programa, metas realistas e possíveis de serem atingidas, visando reforçar a percepção da capacidade pessoal para influenciar a própria vida.

O levantamento inicial do peso e da altura foi feito com as 15 crianças participantes, sendo sete do Grupo I e oito do Grupo II. O segundo levantamento (realizado após 45 dias do levantamento inicial) foi feito com 13 crianças, visto que houve desistência de uma delas (C1) após a segunda sessão e outra criança (C9) apresentou resistência para ter seu peso e altura registrados; logo, não foi possível incluí-la na amostra.

O ganho de peso variou entre trezentos gramas (300 g) a três quilos ( $3 \mathrm{~kg}$ ) e a perda de peso variou entre um quilo e cem gramas $(1,100 \mathrm{~kg})$ e 11 quilos e cem gramas $(11,100 \mathrm{~kg})$. O aumento na altura variou de um a três centímetros, sendo que todas as crianças que ganharam peso também cresceram. Considerando-se a massa corporal calculada pelo IMC e pelo percentil, houve diminuição corporal em nove delas, manutenção em uma e aumento em três, sendo duas excluídas da amostra. Houve alteração no diagnóstico nutricional de uma criança.

De acordo com Valverde \& Patin (2005), é improdutivo manter a perda de peso como a meta mais importante em curto prazo, visto que o potencial biológico individual para o emagrecimento não pode ser previsto. Os autores enfatizam que quando as crianças estão mantendo o peso, elas o estão perdendo, e quando perdem peso, estando perdendo mais do que demonstram. Isso se explica pela velo- 
cidade do crescimento infantil e pelas transformações orgânicas envolvidas, relativas, por exemplo, a ossos e músculos.

A constatação da melhora da convivência das crianças com os colegas pode estar relacionada com a aquisição ou o aumento de recursos pessoais/habilidades sociais para lidar com preconceitos, com o fenômeno bullying.

Não houve relato de reações físicas agressivas, diferentemente do que mostram os dados da entrevista inicial com as crianças, cujo índice era de 7\%. O diálogo foi uma reação que as crianças vítimas do bullying relataram apresentar. Esse recurso pessoal não fora relatado na entrevista inicial, o que mostra, de certa forma, os resultados obtidos com a intervenção grupal, em que se relataram aspectos referentes a habilidades sociais.

Para a análise dos dados da segunda entrevista (final) feita após a participação das crianças no Pacep, foram utilizadas as seguintes categorias: mudanças de vida após a participação no programa, convivência com os colegas, existência do bullying no contexto escolar, reações diante do bullyig na condição de vítimas e autoimagem.

Com relação à primeira categoria de análise, mudanças de vida após a participação no programa, houve relato de alterações em diversas dimensões (Figura 1).

Quanto à segunda categoria, convivência com colegas, 100\% dos participantes relataram que a convivência com os colegas tem sido melhor, menos conflituosa.

Referente à terceira categoria, existência do bullying no contexto escolar, $43 \%$ das crianças afirmaram a continuidade do fenômeno e $57 \%$ negaram a existência do problema. Sugere-se que as habilidades sociais adquiridas por várias crianças para o enfrentamento do bullying podem ter contribuído para a redução da ocorrência do fenômeno no contexto escolar e, consequentemente, para a convivência social mais harmoniosa.

Quanto às reações infantis diante do bullying (quarta categoria), houve relato de xingamento (14\%), expressão de indiferença (14\%), diálogo expressando o desagrado pessoal (7\%) e atitude de ora colocar apelidos, ora expressar indiferença (7\%). Não houve relato de 
reações físicas agressivas, diferente do que mostram os dados da entrevista inicial com as crianças, cujo índice foi de $7 \%$.

\section{Mudanças de vida relatadas pelas crianças após a conclusão do PACEP}

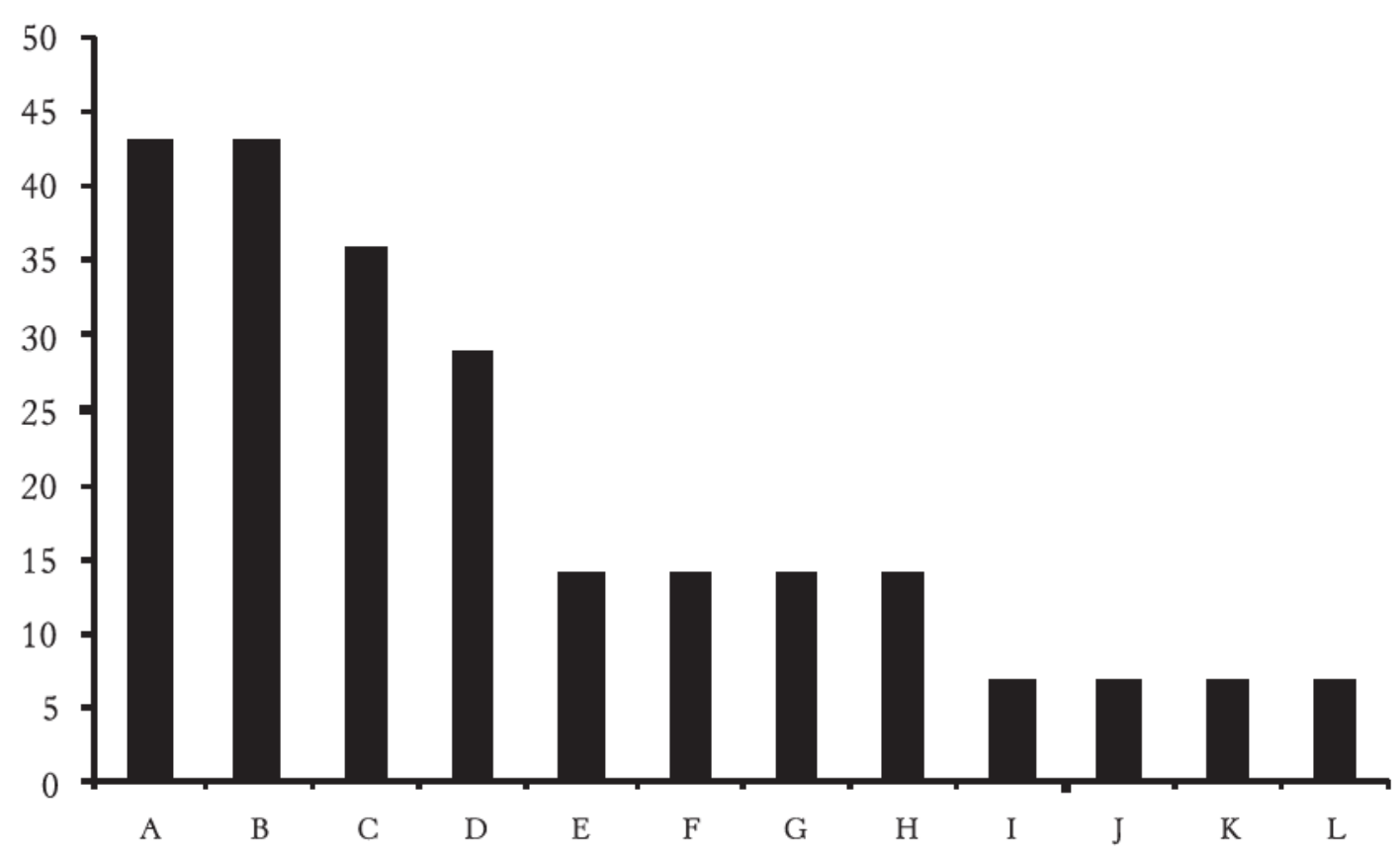

Figura 1 - Porcentagem de mudanças de vida relatadas pelas crianças após a conclusão do Pacep. A. ingestão de menor quantidade de alimentos em geral. B. aumento do consumo de legumes, frutas e verduras. C. emagrecimento. D. diminuição do consumo de guloseimas. E. maior motivação para atividades físicas. F. aumento do círculo de amizades. G. atitude de ignorar as zombarias dos colegas. $H$. diminuição da ansiedade. I. maior vontade de brincar. J. aceitação dos limites impostos pelos pais. K. ciência de passos importantes para emagrecer. L. abandono do hábito de se alimentar em frente à TV.

O diálogo foi uma reação habilidosa que as crianças vítimas do bullying relataram apresentar. Esse recurso pessoal não foi relatado na entrevista inicial com as crianças, o que revela, de certa forma, os resultados favoráveis do Pacep, em que foram abordados aspectos referentes às habilidades sociais.

$\mathrm{Na}$ avaliação de aspectos relativos à autoimagem (quinta categoria), os dados revelaram que $50 \%$ das crianças tinham se considerado mais magras, 29\% achavam-se gordas, 21\% consideravam-se bonitas, $7 \%$ estavam motivadas para iniciar dieta alimentar, $7 \%$ tinham 
variado o seu conceito entre feia e bonita e $7 \%$ achavam que não eram briguentas.

\section{Conclusão}

O presente trabalho teve o propósito de conhecer aspectos nutricionais e psicossociais da vida de crianças em condição de sobrepeso e obesidade, bem como de contribuir para a garantia da qualidade de vida dessas crianças e para a reconstrução de recursos psicológicos para o enfrentamento das implicações da condição pessoal de estarem acima do peso.

A intervenção grupal (Pacep) buscou, baseada em afirmações como de Valverde \& Patin (2005), a incorporação de hábitos alimentares e estilo de vida saudáveis pelas crianças com excesso de peso. Buscou, também, estimular a criação e o desenvolvimento de recursos pessoais, baseados na teoria e em técnicas de habilidades sociais, a fim de auxiliar as crianças a lidarem com a problemática do bullying e favorecer-lhes a melhora do autoconceito e da autoestima.

Apesar de a perda de peso não ter sido um dos objetivos do Pacep, foi constatado que grande parte das crianças emagreceu e que algumas mantiveram sua massa corporal durante o tempo de intervenção. Esses dados parecem revelar a adesão das crianças aos hábitos de vida abordados no Pacep, relativos, por exemplo, à alimentação e à prática de atividades físicas. $54 \%$ das crianças aumentaram o peso e cresceram proporcionalmente em tamanho (altura).

A expressão pessoal de desagrado por meio do diálogo e a ausência de agressão física das crianças diante de atitudes de bullying, confirmadas durante a entrevista final com elas, mostra a aquisição de habilidades sociais infantis. Provavelmente, a aquisição de habilidades sociais pelas crianças contribuiu para que o bullying deixasse, em alguns casos, de constituir fator estressogênico àquelas.

Foi possível observar, ao longo das sessões do Pacep e pelos dados da entrevista final com as crianças, melhora na autoestima de parte considerável delas, revelada, por exemplo, pela capacidade de 
“enxergar" algo de especial em si mesmas, de compreender o próprio valor pessoal e de se ver mais bonitas.

Pelos dados apresentados nos resultados, acredita-se que o Pacep tenha atingido os objetivos propostos. Dada a complexidade do tema obesidade infantil e suas implicações, acredita-se na necessidade de pesquisas mais amplas, que possam, por exemplo, envolver a família e a escola de maneira mais sólida em programas de prevenção e intervenção, levando-se em consideração as influências sociais (familiares e escolares) no estilo de vida da criança, inclusive em seus hábitos alimentares.

Percebe-se, também, a necessidade de atuações multi ou interdisciplinares, em longo prazo, com crianças em condição de sobrepeso e obesidade, a fim de elevar a possibilidade de aprofundamento interventivo quanto às questões envolvidas na problemática $e$ realizar reavaliações constantes do trabalho.

\section{Referências bibliográficas}

ANDRADE, T. M. Estudo psicológico de crianças e adolescentes obesos. In: FISBERG, M. (Org.). Obesidade na infância e adolescência. São Paulo: Fundação BYK, 1995.

BANDURA, A. Social foundations of thought and action. Englewood Cliffs, NJ: Prentice-Hall, 1986.

CABALLO, V. E. Manual de técnica de terapia e modificação do comportamento. São Paulo: Santos, 1996.

Manual de avaliação e treinamento das habilidades sociais. São Paulo: Santos, 2003.

CAMPOS, A. L. R. Aspectos psicológicos da obesidade. Pediatria Moderna, v.29, n.2, p.129-30, 1993.

Aspectos psicológicos da obesidade. In: FISBERG, M. Atualização em obesidade na infância e adolescência. São Paulo: Atheneu, 2005.

; FISBERG, M. Quociente de inteligência de crianças e adolescentes obesos pela escala Wechsler. In: FISBERG, M. Atualização em obesidade na infância e adolescência. São Paulo: Atheneu, 2005. 
DEL PRETTE, Z. A. P.; DEL PRETTE, A. Habilidades sociais: uma área em desenvolvimento. Psicologia: reflexão e crítica, v.9, n.2, p.287-9, 1996.

; _ـ Psicologia das habilidades sociais: terapia e educação. Petrópolis: Vozes, 2002.

; __ Sistema multimídia de habilidades sociais de crianças (manual). São Paulo: Casa do Psicólogo, 2005.

Treinamento de habilidades sociais na escola: o método vivencial e a participação do professor. In: BANDEIRA, M.; DEL PRETTE, Z. A. P.; DEL PRETTE, A. (Orgs.). Estudos sobre habilidades sociais e relacionamento interpessoal. s. 1.: s. n., 2006. FANTE, C. Fenômeno bullying. Campinas: Versus, 2005.

FALCONE, E. M. Grupos. In: RANGÉ, B. Psicoterapia comportamental e cognitiva: pesquisa, prática, aplicações e problemas. Campinas: Editorial Psy, 1995.

FISBERG, M. A Atualização em obesidade na infância e adolescência. São Paulo: Atheneu, 2005.

KAUFMAN, A. Obesidade infanto-juvenil. Pediatria Moderna, v.35, n.4, p.218-22, 1999.

LEMES, S. O. Acompanhamento emocional da obesidade na infância e adolescência. In: FISBERG, M. Atualização em obesidade na infância e adolescência. São Paulo: Atheneu, 2005.

LOPES NETO, A; SAAVEDRA, L. H. Diga não para o bullying; programa de redução do comportamento agressivo entre estudantes. Rio de Janeiro: Abrapia, 2003.

SANCHEZ, A.V.; ESCRIBANO, E. A. Medição do autoconceito. Bauru: Edusc, 1999.

VALVERDE, M. A.; PATIN, R. V. Aconselhamento dietético e mudanças de comportamento. In: FISBERG, M. Atualização em obesidade na infância e adolescência. São Paulo: Atheneu, 2005. 



\title{
5 \\ ANÁLISE DA REGULAMENTAÇÃo SOBRE EDUCAÇÃO INCLUSIVA NO estado de São Paulo
}

\author{
Marileide Antunes de Oliveira ${ }^{1}$ \\ Lúcia Pereira Leite ${ }^{2}$
}

\section{Introdução}

A inclusão tem suscitado uma série de discussões nos mais diversos segmentos: educacionais, sociais e políticos, entre outros. Como movimento que advoga a participação social de todo e qualquer indivíduo em variados contextos, a inclusão tem como uma de suas bases as mudanças ocorridas na relação entre a sociedade e as pessoas com deficiência ao longo da história.

Aranha (2002) afirma que essas transformações podem ser compreendidas a partir de três paradigmas principais. O primeiro, denominado Paradigma da Institucionalização, marcou a alocação das pessoas com deficiência em instituições. Assim, durante a primeira metade do século XX, instituições asilares e escolas especiais foram criadas com a função de resguardar essas pessoas do convívio social, de modo a garantir o bom funcionamento da sociedade, uma vez que tais indivíduos eram considerados como um ônus para a família, para a Saúde Pública e para a comunidade em geral.

1 Programa de Pós-Graduação em Psicologia do Desenvolvimento e Aprendizagem da Unesp - Bauru.

2 Idem. 
O avanço das ciências naturais, a partir da década de 1960, contribuiu com o estabelecimento de relações entre manifestações sintomatológicas e lesões orgânicas. Assim, causas ambientais passaram a ser atribuídas à gênese das deficiências, tomando como base o conceito de normalização, definido por um padrão de funcionamento considerado "normal" a partir do qual se caracterizavam as condições de desvio, todos representados estatisticamente (Kassar, 2000).

Nesse contexto, institui-se o segundo paradigma, denominado Paradigma dos Serviços. Embora respaldado por uma noção de deficiência centrada no indivíduo, isto é, pela ideia de que uma limitação intrinsecamente orgânica distancia a pessoa com deficiência dos demais indivíduos não deficientes (Aranha, 1991), esse paradigma trouxe como avanço o afastamento das pessoas com deficiência das instituições e a provisão de programas comunitários planejados para oferecer serviços voltados a essa população.

Na década de 1990, no entanto, passou-se a discutir que a provisão de serviços por si só não seria suficiente para garantir a participação das pessoas com deficiência no contexto social e que, consequentemente, caberia à sociedade se reorganizar para favorecer o acesso de todos os cidadãos, deficientes ou não, a todo e qualquer recurso, serviço, equipamento e processo disponíveis no meio social.

Esses questionamentos, então, deram origem a movimentos sociais em diversas partes do mundo, que incidiram sobre o terceiro paradigma, denominado Paradigma dos Suportes. Este, por sua vez, caracteriza-se por uma mudança no foco de atenção, ou seja, propõe que cabe ao contexto promover transformações de naturezas diversas a fim de atender as especificidades de todo e qualquer segmento populacional, dentre eles, o das pessoas com deficiência (Leite, 2003).

A adoção do Paradigma de Suportes, portanto, implica a participação efetiva de cada uma das esferas sociais, incluindo a sociedade civil, os representantes do poder público e a parcela da população cujas especificidades necessitam ser atendidas. Aranha (2001, p.19) complementa que a função dos suportes no arranjo dessas ações é 
[...] favorecer o que se passou a denominar inclusão social, processo de ajuste mútuo, onde cabe à pessoa com deficiência manifestar-se com relação a seus desejos e necessidades e à sociedade, a implementação dos ajustes e providências necessárias que a ela possibilitem o acesso e a convivência no espaço comum, não segregado. (negrito da autora)

No âmbito educacional, a necessidade de se construir um novo modelo de ensino, respaldado nos princípios da inclusão, passou a ser discutida a partir de uma assembleia realizada na Espanha em junho de 1994, com representantes de 88 governos e 25 organizações internacionais (Declaração de Salamanca, 1994). Com isso, tornou-se diretiva mundial reorganizar os sistemas educacionais para garantir o acesso, o ingresso e a permanência de todo e qualquer aluno nas mais diversas modalidades de escolarização (Claser, 2001).

Desde então, políticas públicas têm sido elaboradas para subsidiar as ações a serem implementadas na construção de uma escola para todos. No contexto brasileiro, têm-se as Diretrizes Nacionais para a Educação Especial na Educação Básica (Brasil, MEC/SEESP, 2001) como uma das principais referências normativas da inclusão educacional. Entre os avanços trazidos nesse documento, pode-se destacar a proposição de novos enfoques, tanto no papel da Educação Especial como na população a se beneficiar dessa modalidade de ensino.

Dessa forma, as Diretrizes Nacionais sugerem que a Educação Especial deve compor um conjunto de recursos e serviços de natureza dinâmica, temporária e relativa para o atendimento de alunos com necessidades educacionais especiais (Oliveira \& Leite, 2002). Além disso, ao adotar o conceito de necessidades educacionais especiais ${ }^{3}$

$3[\ldots]$ I - dificuldades acentuadas de aprendizagens ou limitações no processo de desenvolvimento que dificultem o acompanhamento das atividades curriculares, compreendidas em dois grupos: a) aquelas não vinculadas a uma causa orgânica específica; b) aquelas relacionadas a condições, disfunções, limitações ou deficiências; II - dificuldades de comunicação e sinalização diferenciadas dos demais alunos, demandando a utilização de linguagens e códigos aplicáveis; III - altas habilidades/superdotação, grande facilidade de aprendizagem que os leve a dominar rapidamente conceitos, procedimentos e atitudes. (Brasil, MEC/SEESP, 2001, p.17) 
(NEEs), o mesmo documento propõe que as dificuldades escolares, mesmo relacionadas a causas orgânicas, devem ser identificadas " $d u$ rante o processo educacional, e não fora dele” (Oliveira, 2006, p.261, itálicos da autora).

As Diretrizes Nacionais, por conseguinte, têm orientado políticas públicas em âmbito estadual, entre elas, a Resolução $\mathrm{SE} \mathrm{n}^{\circ} 8 /$ 2006, que foi elaborada no estado de São Paulo a fim de nortear a inclusão educacional nesse contexto, particularmente no que se refere à indicação dos suportes a serem implementados para o atendimento de alunos com necessidades educacionais especiais inseridos no ensino regular da rede estadual de ensino.

Destarte, as políticas públicas na área de inclusão educacional têm sido objeto de análise por alguns autores (Góes \& Laplane, 2004; Oliveira, 2006; Pietro, 2003). Tais autores sugerem que alguns avanços vêm ocorrendo em relação à construção de um sistema educacional inclusivo, mas que, no entanto, permanecem algumas divergências e lacunas entre aspectos formais das respectivas legislações e a realidade escolar.

Dadas as considerações mencionadas, sugere-se queé importante estabelecer um panorama da amplitude das políticas públicas elaboradas em âmbito estadual. Sendo assim, o presente texto objetiva descrever os principais enunciados da Resolução SE nº 8/2006 e, além disso, discutir criticamente esses enunciados levando em consideração alguns dos pressupostos considerados fundamentais na construção do ensino inclusivo (Brasil, MEC/SEESP, 2001), quais sejam: a) processos de ensino e aprendizagem, b) plano de trabalho didático-pedagógico, c) avaliação educacional e d) formação continuada de professores.

\section{A Resolução SE n 8/2006}

A Resolução SE n 8/2006 faz uma releitura e altera artigos e parágrafos da Resolução SE n 95, de 21.11.2000, para regulamentar o funcionamento para a sala de recursos e classe especial no esta- 
do de São Paulo, bem como determina a clientela a se beneficiar desses serviços. Foi criada em âmbito estadual em função das necessidades de ofertar condições, em curto prazo, para o atendimento dos alunos com necessidades educacionais especiais nas redes públicas e de afirmar o modelo de educação inclusiva vislumbrado nacionalmente a partir da Declaração de Salamanca (1994).

O papel da sala de recursos e das classes especiais no contexto de educação inclusiva já aparece destacado nas Diretrizes Nacionais da Educação Especial na Educação Básica (Brasil, MEC/SEESP, 2001), documento orientador da Resolução SE nº 8/2006. De acordo com as Diretrizes Nacionais, esses serviços têm como função servir de suporte à educação inclusiva, uma vez que se constituem como elementos-chave na provisão das condições necessárias para que alunos com necessidades educacionais especiais possam acessar a proposta educacional ofertada nas redes de ensino. De acordo com as Diretrizes Nacionais, a sala de recursos é definida como um

[...] serviço de natureza pedagógica, conduzido por professor especializado que suplementa (no caso dos superdotados) e complementa (para os demais alunos) o atendimento educacional realizado em classes comuns da rede regular de ensino. (idem ibidem p.50)

A classe especial, por sua vez, caracteriza-se por

[...] uma sala de aula, em escola de ensino regular, em espaço físico e modulação adequada. Nesse tipo de sala, o professor de educação especial utiliza métodos, técnicas, procedimentos didáticos e recursos pedagógicos especializados e, quando necessário, equipamentos e materiais didáticos específicos, conforme série/ciclo/etapa da educação básica, para que o aluno tenha acesso ao currículo de base nacional comum. (idem ibidem p.52)

A partir do especificado nas Diretrizes Nacionais, a Resolução $\mathrm{SE}^{\circ}$ 8/2006 dispõe sobre o funcionamento das salas de recursos e classes especiais na rede estadual de ensino. A seguir é apresentada uma breve descrição da referida Resolução, com o objetivo de res- 
paldar a análise a ser realizada em momento posterior, em uma alusão ao ensino inclusivo.

Em um primeiro momento, podem-se citar as justificativas que levaram à elaboração da Resolução, que se referem à existência de três condições principais: a) oferta de condições para o atendimento de alunos com necessidades educacionais especiais na rede pública, b) utilização das Diretrizes Nacionais como referente legal e c) a Resolução como uma política de ação governamental pautada nos princípios da inclusão educacional.

Focalizando pontualmente, isso modifica os parágrafos 1,2 e 3 do Artigo 6 da Resolução n ${ }^{\circ}$ 95/00, que tratam da terminalidade específica, fazendo uma alusão à adoção desse procedimento, que deve ser efetivado apenas em casos cujas necessidades educacionais são justificáveis contando com a expressa anuência da família, por intermédio de solicitação do professor junto à direção escolar para que se dê início a esse processo. Porém, não se deixa claro qual é a população acadêmica específica que pode fazer uso de tal procedimento.

Para tanto, é designada uma comissão multidisciplinar para avaliar a aprendizagem do aluno e emitir parecer acadêmico de modo que, posteriormente, a escola, em parceria com outras instâncias vinculadas ao poder público - órgãos of iciais e instituições -, oriente a família no encaminhamento do aluno a programas especiais dos quais ele possa se beneficiar, como, por exemplo, programas de iniciação ao mundo do trabalho.

Nesse caso, o papel da unidade escolar é verificar se a escola esgotou as alternativas de propostas didático-pedagógicas para que esse aluno pudesse aprender o mínimo do conteúdo acadêmico previsto para a série, de acordo com a Lei de Diretrizes e Bases 9496/ 96 (LDB, 1996) e, a partir disso, mobilizar a equipe escolar a fim de encontrar caminhos possíveis para favorecer a independência desse aluno, bem como sua inserção na sociedade. Ressalta-se, ainda, que a terminalidade deve ser vista com parcimônia e adotada como último recurso.

Outro fato a ser destacado é a implementação dos Serviços de Apoio Pedagógico Especializado (Sapes). A Resolução indica, em 
seu Parágrafo Único do Artigo 8, a realização de aulas ministradas por professor especialista em sala de recursos, em classes especiais ou, ainda, em caráter itinerante, por meio de atuação nas redes de ensino de determinada região.

Já em relação à população, o inciso 5 do Artigo 10 define que alunos de qualquer série ou etapa do Ensino Fundamental ou Médio podem se beneficiar do atendimento em sala de recursos. Já para os alunos cujas condições são específicas, propõe-se a criação de classes especiais, nos casos em que o grau de desenvolvimento do aluno seja correspondente ao exigido para o Ciclo I.

Para a organização do Sape, de acordo com o Artigo 9 e respectivos incisos, deve-se considerar o número de alunos, bem como o período e a frequência de atendimento. Destaca-se que a Resolução prevê, no caso do atendimento itinerante, o desenvolvimento de atividades de apoio para o aluno com NEEs e, além disso, a atuação em trabalho articulado junto aos demais professores.

Os requisitos necessários para a atuação do professor no Sape, segundo o inciso II do Artigo 10, são a habilitação ou licenciatura plena em Pedagogia e, além disso, o curso de especialização com o mínimo de 360 horas de duração. O seu plano de trabalho deve, de acordo com o Artigo 11, ser baseado nas especificidades da demanda existente e, além disso, considerar o disposto nas Diretrizes Nacionais da Educação Especial na Educação Básica.

Por fim, ao tratar da rede de ensino em conjunto, o inciso I do Artigo 14 aponta a realização de um levantamento das classes especiais, das salas de recursos e dos atendimentos itinerantes a fim de aperfeiçoar e racionalizar o serviço. Para as unidades escolares que não comportam a existência do Sape, a Resolução garante, por meio do Artigo 13, o atendimento em caráter itinerante a ser realizado por professor especialista atuante no Sape da região.

Fazendo um contraponto com a Resolução SE n 95/2000, percebe-se que, embora esta já estabeleça que mudanças devam ser implementadas nos sistemas de ensino para atender aos alunos com necessidades educacionais especiais, a preocupação em claramente afirmar a reiteração dos pressupostos estabelecidos pela Declara- 
ção de Salamanca nas políticas públicas nacionais fica clara apenas até a publicação da Resolução no 8/2006.

Ainda, o papel dos Sapes na construção de um ensino inclusivo aparece de maneira nítida somente na Resolução n ${ }^{\circ}$ 8/2006. Assim, pode-se dizer que, na época da promulgação da Resolução $\mathrm{SE} \mathrm{n}^{\circ}$ 95/ 2000, o papel da Educação Especial esteve atrelado ao Paradigma dos Serviços (Aranha, 1991), no contexto brasileiro. Consequentemente, uma relação mais bem firmada com os princípios da educação inclusiva, por sua vez, ocorreu com a publicação da Resolução $n^{\circ} 8 / 2006$.

Tomando como base as questões acima, são apresentadas algumas considerações a respeito da extensão das mudanças educacionais propostas, em âmbito legal, pela Resolução n ${ }^{\circ}$ 8/2006, especialmente no que tange aos Sapes, à população atendida e ao atendimento prestado nesse contexto.

\section{A Resolução SE $n^{\circ} 8 / 2006$ e os pressupostos do ensino inclusivo}

A proposição do ensino inclusivo tem como base a concepção de um novo modelo de atuação educacional, contrário ao ensino homogêneo. Neste, a prática pedagógica fundamenta-se na adoção de atuações pouco flexíveis e que desconsideram as particularidades de cada aluno no aprender. Diferentemente, em um modelo de ensino inclusivo, preconizam-se as diferenças individuais na relação de ensino e aprendizagem e, como resultado, tem-se uma atuação pedagógica cuja finalidade é garantir respostas educacionais à diversidade presente na sala de aula (Leite, 2004).

Por conseguinte, o ensino inclusivo tem como pressuposto a flexibilização do ensino ofertado nos sistemas escolares em relação a aspectos curriculares, seja nos objetivos, no conteúdo, nos recursos, nas estratégias didático-pedagógicas, nos instrumentos ou na forma de avaliação, entre outros, a fim de favorecer e criar condições para que todos os alunos tenham acesso ao currículo comum. 
A seguir, os enunciados da Resolução, acima descritos, são analisados tomando como base os seguintes aspectos, considerados pelas Diretrizes Nacionais (Brasil, MEC/SEESP, 2001) como fundamentais na constituição do ensino inclusivo: a) processos de ensino e aprendizagem, b) plano de trabalho didáticopedagógico, c) avaliação educacional e d) formação continuada de professores.

Inicialmente, pode-se mencionar o entendimento dos processos de ensino e de aprendizagem tal como apresentados na Resolução. No parágrafo correspondente à Justificativa, o documento enfatiza o atendimento de alunos com necessidades especiais pautado nos princípios da inclusão. Já no inciso II do Artigo $9^{\circ}$, há a indicação de trabalho articulado entre professor especialista e equipe pedagógica, como referência à condução do ensino.

Por um lado, supõe-se que a mesma compreensão dos processos de ensino e de aprendizagem adotada nas Diretrizes Nacionais pode ser aplicada à Resolução. De acordo com o primeiro documento, o ensino deve ser flexibilizado e estar relacionado à realização de adaptações curriculares de conteúdos, metodologias e recursos didáticos; já sobre a aprendizagem, esta é descrita como o processo cooperativo de troca de experiência entre os diferentes alunos que compõem a sala de aula, entre eles os alunos com necessidades educacionais especiais.

Entretanto, embora haja, nas Diretrizes Nacionais, a proposição de mudanças amplas e profundas quanto aos diversos componentes de escolarização, entre eles os processos de ensino e de aprendizagem, percebe-se que a Resolução deixa de explicitar claramente a vinculação entre uma nova concepção acerca dos processos de ensino e de aprendizagem e o atendimento oferecido nas salas de recursos e classes especiais.

Fazendo uma alusão aos preceitos da psicologia históricocultural, tem-se o ensino como um processo colaborativo entre educador e criança, em que o papel do professor é atuar como mediador, reunindo conhecimentos e estratégias pedagógicas imprescindíveis ao desenvolvimento das funções psicológicas 
superiores, ${ }^{4}$ e o papel do aluno, por sua vez, é o de participar ativamente desse processo, a fim de realizar sozinho o que, em um primeiro momento, é possível apenas com a ajuda do professor (Vygotsky, 2001).

Sendo assim, pode-se pensar que, no contexto de ensino inclusivo, o papel do professor é identificar e utilizar as ferramentas pedagógicas que propiciem ao aluno com necessidades educacionais especiais o desenvolvimento das funções psicológicas superiores. Essa compreensão acerca dos processos de ensino e de aprendizagem torna-se fundamental, uma vez que éno atendimento especializado que devem ser promovidas as condições para que determinada população acesse a proposta educacional ofertada, e tal consideração deixa de ser mencionada na Resolução.

Já em relação ao plano didático-pedagógico, tem-se como um dos avanços da Resolução a proposição de trabalho conjunto entre professor especialista e demais professores no planejamento do ensino. Ao apontar a possibilidade de trabalho conjunto, a Resolução sustenta que o professor especialista e o educador do ensino comum formulem propostas de ensino complementares.

Para Karagiannis, Stainback \& Stainback (1999), os principais elementos a serem considerados na elaboração de um plano didático-pedagógico respaldado no ensino inclusivo são o uso de objetivos de ensino flexíveis, considerando as necessidades de cada aluno no acompanhamento da proposta educacional, e a realização de adaptações de atividade e/ou múltiplas. De maneira consonante com a Resolução, os autores também afirmam que o trabalho em equipe é importante para se planejar e executar programas ou estratégias educacionais com o objetivo de promover as condições necessárias para a aprendizagem no contexto da escola inclusiva.

Em relação à avaliação educacional, a Resolução indica que esta deve ser realizada pela equipe escolar restringindo-se, de forma como

4 São as funções que definem a natureza humana dos indivíduos, tais como: pensamento, linguagem, cálculo, memória, entre outras, e que são determinadas sociohistoricamente (Vygotsky, 2001). 
a apresentada no documento, aos casos em que se faz necessária a adoção de terminalidade específica. Embora a Resolução explicite a importância de uma avaliação educacional conduzida por uma equipe escolar e, além disso, tendo a participação da família nesse processo, algumas questões ainda permanecem como lacunas no documento.

Por avaliação educacional entende-se o mapeamento sistemático das condições de ensino, sendo isto uma ferramenta importante no estabelecimento de mudanças no processo de ensino e aprendizagem(Vasconcellos, 2003). Essa visão corrobora a descrição dada pelos Parâmetros Curriculares Nacionais (PCN) (Brasil, MEC/SEF, 1997, p.57), segundo os quais a avaliação constitui-se como

[...] ação que ocorre durante todo o processo de ensino e aprendizagem e não apenas em momentos específicos caracterizados como fechamento de grandes etapas de trabalho. [...] Pressupõe também que a avaliação se aplique não apenas ao aluno, considerando as expectativas de aprendizagem, mas às condições oferecidas para que isso ocorra. Avaliar a aprendizagem, portanto, implica avaliar o ensino oferecido [...].

Vale ressaltar que a proposta de avaliação educacional presente na Resolução tem atendido parcialmente aos princípios do ensino inclusivo, pois, embora considere a necessidade de um trabalho conjunto da equipe escolar, por outro lado, deixa de indicar como parte importante desse processo a análise das condições de ensino ao priorizar um tipo de avaliação cujo foco recai sobre o aluno. Dessa maneira, é necessário pensar na avaliação em relação ao que se espera do aluno em termos de aprendizagem em referência aos conteúdos ensinados para, a partir disso, criar as condições para que isso ocorra (Brasil, MEC/SEESP, 2001).

Em outro ponto, ao tratar da formação de professores, a Resolução atribui especial importância à atuação de profissionais habilitados ou especializados. Sendo assim, pode-se dizer que esse aspecto representa um avanço, uma vez que vem conferir singularidade à formação - inicial ou continuada - do educador. Dentro de uma proposta de ensino inclusivo, esta tem como objetivo permitir ao pro- 
fessor especializado rever posturas diante de sua função no contexto educativo e, além disso, garantir as condições para a organização de um trabalho pedagógico responsivo à diversidade (Mantoan, 2001).

Por fim, uma questão a ser apontada na Resolução diz respeito ao levantamento das classes especiais, das salas de recursos e dos atendimentos itinerantes com o objetivo de garantir a qualidade dos serviços. Embora o documento explicite a importância de levar em consideração a demanda existente na rede pública, considera-se que poderiam também ser mencionadas as articulações do Sape junto às instâncias ligadas à saúde, para garantir a viabilização de parcerias de suportes operacionais para a efetivação da inclusão escolar, por exemplo, com equipes multiprofissionais formadas por assistentes sociais, fonoaudiólogos, médicos pediatras e psicólogos, entre outros, uma vez que para a implementação da educação inclusiva são necessárias ações interligadas entre vários instâncias auxiliares ao desenvolvimento educacional.

A partir do acima exposto, pode-se dizer que alguns aspectos da Resolução SE nº 8/2006 estão em conformidade com os elementos considerados importantes na promoção do ensino inclusivo, como indicado pelas Diretrizes Nacionais (Brasil, MEC/SEESP, 2001). São eles: 1) proposição de trabalho em conjunto entre professor especialista e demais professores; 2) articulações na rede de ensino; 3 ) elaboração de plano de trabalho didático-pedagógico; e 4) participação da família no processo educacional.

No contraponto, algumas lacunas, ou falta de maiores descrições, podem ser observadas em relação aos processos de ensino a serem efetivados e à avaliação educacional, os quais são apresentados brevemente e de maneira superficial no que tange aos subsídios teórico-operacionais.

\section{Conclusão}

O presente trabalho buscou realizar uma análise da Resolução $\mathrm{SE}^{\circ}$ 8/2006 como parte das políticas públicas que norteiam a cons- 
trução da educação inclusiva no estado de São Paulo e, além disso, procurou-se compreendê-la à luz de aspectos como: processos de ensino e aprendizagem, plano de trabalho didático-pedagógico, avaliação educacional e formação continuada de professores, os quais são apontados pelas Diretrizes Nacionais (Brasil, MEC/SEESP, 2001) como elementos constituintes do ensino inclusivo.

Pode-se dizer que este estudo apresenta como avanços a explicitação de como componentes importantes na construção de um ensino inclusivo estão apresentados na referida Resolução e, além disso, a análise desta, levando em consideração sua relação com o disposto nas Diretrizes Nacionais a respeito do ensino na diversidade. Sugere-se que reflexões dessa natureza são particularmente importantes, uma vez que avaliar a efetividade das políticas públicas formuladas em nível estadual é parte integrante do processo de reorganização dos sistemas educacionais, a qual é especificada na Declaração de Salamanca (1994).

Nesse caso, propõe-se que esses questionamentos se estendam para as demais instâncias que compõem o sistema educacional, tais como a comunidade escolar, pois é nesta que são cumpridas as normas estabelecidas pela legislação. Como sugerido por Góes \& Laplane (2004) e Palma Filho \& Alves (2003), há necessidade de se repensar as ações que têm sido veiculadas no âmbito das políticas públicas, de modo a obter avanços na construção do ensino inclusivo.

De maneira consonante à literatura referente ao amparo legal da educação inclusiva (Góes \& Laplane, 2004; Oliveira, 2006; Pietro, 2003), aponta-se a necessidade de elaboração de políticas públicas pautadas nas demandas reais das escolas. Para tanto, torna-se importante que os documentos legais explicitem claramente o compromisso com as mudanças a serem implementadas para o ensino na diversidade. Assim como apontado por Oliveira (2006), em análise acerca das Diretrizes Nacionais, alguns avanços conceituais são encontrados na Resolução SE nº 8/2006, no entanto, lacunas permanecem quanto à proposição de norteadores efetivos no âmbito das ações.

Nesse propósito, a Secretaria da Educação do estado de São Paulo promulgou a Resolução SE n 11/2008, com o objetivo de nortear 
a educação escolar dos alunos com necessidades educacionais especiais (NEEs) no estado. Da mesma forma, como é apontado na Resolução SE nº 8/2006, a nova Resolução enfatiza a importância da participação da família e do trabalho pedagógico articulado no atendimento à diversidade. Como avanços, esse documento aponta a ampliação da qualidade da oferta da Educação Especial nas redes de ensino, funções mais bem definidas para o professor especialista, a implementação de avaliações contínuas e periódicas e, além disso, o atendimento dos alunos com NEEs em espaço não segregado. Como indefinições, no entanto, ainda permanecem a abordagem tangencial dos processos de ensino e de aprendizagem, bem como do papel da avaliação educacional. O documento ainda é pouco preciso sobre como proceder no que se refere ao progresso acadêmico desse alunado, deixando de explicitar claramente os critérios para a definição de necessidades educacionais especiais e terminalidade específica, por exemplo.

Por fim, sugere-se que estudos futuros sejam realizados a fim de analisar a efetividade das políticas públicas elaboradas recentemente para subsidiar a construção do ensino inclusivo. Pensar nos desdobramentos desse processo para a sociedade em geral mostra-se como tarefa importante a ser empreitada também em outros estudos. Como defendem alguns autores (Ferreira \& Ferreira, 2004; Mantoan, 2004; Mittler, 2003; Oliveira, 2006), são necessários esforços conjuntos envolvendo escolas, poder público, representantes civis, entre outros, na construção de uma nova realidade educacional.

O compromisso da universidade e, em decorrência, de seus pesquisadores, reside não só na garantia da promulgação de leis, junto ao Poder público, que promovam condições de ensino a todos os alunos, mas também na análise cuidadosa dessas prescrições normativas na tentativa de ajustá-las a sua finalidade, caso contrário processos educacionais serão amparados por um conjunto de normas e regras que pouco contribui para a efetividade da educação inclusiva no cenário brasileiro. 


\section{Referências bibliográficas}

ARANHA, M. S. F. A interação social e o desenvolvimento das relações interpessoais do deficiente em ambiente integrado. Dissertação (Doutorado em Psicologia Experimental), Instituto de Psicologia, Universidade de São Paulo, São Paulo, 1991.

A inclusão social da criança especial. In: SOCIEDADE PESTALOZZI (Org.). A criança especial. Niterói: 2001, p.19.

A sociedade brasileira, a pessoa que apresenta necessidades especiais, a acessibilidade e a construção de uma sociedade inclusiva. Boletins, Salto, 2002. Disponível em: <http:// www.tvebrasil.com.br/salto/boletins2002/feei/tetxt1.htm>. Acesso em: 13 mar. 2006.

BRASIL. MEC/SEF. Parâmetros curriculares nacionais: introdução aos parâmetros curriculares nacionais. Brasília: Secretaria de Educação Fundamental, 1997.

BRASIL. MEC/SEESP. Diretrizes Nacionais para a Educação Especial na Educação Básica. Brasília: Conselho Nacional de Educação, 2001. Disponível em: < www.mec.gov.br/seesp >. Acesso em: 13 mar. 2006.

CLASER, E. A. Projeto de educação inclusiva (Pr): propostas para a educação na diversidade. Dissertação (Mestrado em Engenharia de Produção), Universidade Federal de Santa Catarina, Florianópolis, 2001.

DECLARAÇÃO DE SALAMANCA. Conferência realizada em 10 de junho de 1994. Disponível em: <http://portal.mec.gov.br/seesp/ arquivos/pdf/Salamanca.pdf>. Acesso em: 10 abr. 2006.

FERREIRA, M. C. C.; FERREIRA, J. R. Sobre inclusão, políticas públicas e práticas pedagógicas. In: GÓES, M. C. R.; LAPLANE, A. L. F. Políticas e práticas de educação inclusiva. Campinas: Autores Associados, 2004.

GÓES, M. C. R.; LAPLANE, A. L. F.. Políticas e práticas de educação inclusiva. Campinas: Autores Associados, 2004, cap. 4 e 5.

KARAGIANNIS, A.: STAINBACK, W.; STAINBACK, S. Fundamentos do ensino inclusivo. In: STAINBACK, S.; STAINBACK, W. Inclusão: um guia para educadores. Porto Alegre: Artmed, 1999, cap. 1. 
KASSAR, M. C. M. Conhecimento - Direito ao conhecimento e modos de conhecer: novas condições. III Conferência de Pesquisa Sociocultural. Campinas, 2000. Disponível em: <www.fae.unicamp.br/ br2000/conh9.htm - 13k >. Acesso em: 09 mar. 2006.

LEI DE DIRETRIZES E BASES DA EDUCAÇÃO NACIONAL. Lei $N^{o} 9.394$ de 20 de dezembro de 1996. Disponível em: <http://portal.mec.gov.br/ index.php?option $=$ content $\&$ task $=$ view $\&$ id $=78 \&$ Itemid $=221>$. Acesso em: 08 mai. 2006.

LEITE, L. P. A intervenção reflexiva como instrumento de formação continuada do educador: um estudo em classe especial. Dissertação (Doutorado em Educação), Universidade Estadual Paulista, UNESP Marília, 2003.

Educador especial: reflexões e críticas sobre sua prática pedagógica. Revista Brasileira de Educação Especial, Marília: v.10, p.13142, 2004.

MANTOAN, M. T. E (Org.) Caminhos pedagógicos da inclusão: como estamos implementando a educação (de qualidade) para todos nas escolas brasileiras. São Paulo: Memnon, 2001.

O direito de ser, sendo diferente, na escola. In: OMOTE, S. Inclusão: intenção e realidade. Marília: Fundepe, 2004, p.113-43.

MITLLER, P. Educação inclusiva: contextos sociais. Porto Alegre: Artmed, 2003.

OLIVEIRA, A. A. S. Inclusão no Brasil: políticas públicas para o educando com necessidades educacionais especiais. In: GENARO, K. F.; LAMÔNICA, D. A. C.; BEVILACQUA, M. C. O processo de comunicação: contribuição para a formação de professores na inclusão de indivíduos com necessidades educacionais especiais. São José dos Campos: Pulso, 2006, cap. 19.

; LEITE, L. P. O papel da Educação Especial no sistema educacional inclusivo. Jornal Diário de Marília, Marília, SP. 29 out. 2002.

PALMA FILHO, J. C.; ALVES, M. L. Formação continuada: memórias. In: BARBOSA, R. L. L. (Org.). Formação de professores: desafios e perspectivas. São Paulo: Editora Unesp, 2003, p.279-96.

PIETRO, R. G. Políticas públicas de inclusão: compromissos do poder público, da escola e dos professores. Revista de Educação, Apeoesp, $\mathrm{n}^{\circ}$ 16, mar. 2003. Disponível em: <http:// www.educacaoonline.pro.br>. Acesso em: 09 out. 2006. 
RESOLUÇÃO SE nº 8/2006, de 26 de janeiro de 2006. Secretaria da Educação do Estado de São Paulo. Disponível em: <http://lise.edunet.sp.gov.br/ sislegis/detresol.asp?strAto $=200601260008>$. Acesso em: 18 mai. 2006.

RESOLUÇÃO SE nº 95/2000, de 21 de novembro de 2000. Secretaria da Educação do Estado de São Paulo. Disponível em: <http:// lise.edunet.sp.gov.br/paglei/resolucoes/95_2000.htm>. Acesso em: 03 jun. 2009.

RESOLUÇÃO SE nº 11/2008, de 31 de janeiro de 2008. Secretaria da Educação do Estado de São Paulo. Disponível em: (www.apaesaopaulo.org.br). Acesso em: 03 jun. 2009.

VASCONCELLOS, C. S. Avaliação da aprendizagem: práticas de mudança - por uma práxis transformadora. São Paulo: Libertad, 2003, p.11-39.

VYGOTSKY, L. S. A construção do pensamento e da linguagem. São Paulo: Martins Fontes, 2001. 



\title{
6 \\ A INFLUÊNCIA DE PROBLEMAS DE COMPORTAMENTO SOBRE O DESEMPENHO ESCOLAR ${ }^{1}$
}

\author{
Marta Regina Gonçalves Correia-Zanini ${ }^{2}$ \\ Olga Maria Piazentin Rolim Rodrigues ${ }^{3}$
}

\section{Introdução}

O ambiente escolar é um lugar previamente organizado para promover oportunidades de aprendizagem, na medida em que é socialmente construído por alunos e professores a partir das interações que estabelecem entre si e com as demais variáveis do ambiente (Bragança, Ferreira \& Pontelo, 2008). O fato de somente alguns alunos aprenderem evidencia um fracasso do nosso sistema educacional que, de acordo com Pereira, Marinotti \& Luna (2004), é motivo de preocupação, principalmente no que se refere à "alfabetização", isto porque ler e escrever são habilidades para a vida fora da escola e o fracasso em tais habilidades implicam em desinteresse, baixo desempenho e evasão escolar.

Atualmente, observa-se uma crescente preocupação com os efeitos do baixo desempenho acadêmico sobre o desenvolvimento in-

1 O estudo é parte integrante da dissertação de mestrado da primeira autora, sob orientação da segunda autora.

2 Programa de Pós-Graduação em Psicologia do Desenvolvimento e Aprendizagem da Unesp - Bauru.

3 Idem. 
fantil, pois, como apontam Okano et al. (2004), ele pode contribuir com o atraso escolar, com a evasão, com a repetência e, consequentemente, interferir na autoestima, na capacidade produtiva, na aceitação e na popularidade entre os colegas. Para Pacheco \& Sisto (2005), os alunos com dificuldades de aprendizagem também se percebem como menos adaptados à escola por não conseguirem resolver questões acadêmicas a que estão expostos constantemente.

\section{Baixo rendimento acadêmico: conceito e implicações}

É corrente na literatura a utilização do termo "dificuldade de aprendizagem" atrelado ao rendimento acadêmico. Para Correia (2004), ele surgiu da necessidade de se compreender a razão pela qual um conjunto de alunos aparentemente "normais" apresentava rendimento acadêmico abaixo da média, principalmente em áreas como leitura, escrita e aritmética. Daí retira-se a concepção de que a dificuldade de aprendizagem envolve a comparação entre o desempenho acadêmico esperado, tendo como referência um padrão médio, e o desempenho real, abaixo da média, apresentado pelo indivíduo (Pacheco, 2005; Correia, 2004).

Alguns estudos apontam que é grande o número de crianças cujo desempenho escolar está aquém do esperado. No estudo realizado por Dias, Enumo \& Turini (2006), por exemplo, mais de 50\% dos 172 estudantes de $2^{\mathrm{a}}$ a $5^{\mathrm{a}}$ série de uma escola pública, na faixa etária entre oito a 19 anos, tiveram classificação inferior no total e nos subtestes do Teste de Desempenho Escolar (TDE), em duas avaliações, as quais ocorreram no intervalo de um ano.

A pesquisa realizada por Oliveira, Boruchovitc \& Santos (2008) nos mostra que o baixo rendimento, medido pelo conceito obtido pelo aluno nas avaliações escolares, tem relação com algumas habilidades específicas que são importantes para o aproveitamento escolar, como a leitura. Os autores exploraram a relação entre compreensão em leitura e desempenho escolar em 434 alunos do Ensino 
Fundamental de escolas públicas. Aplicou-se, coletivamente, o Teste de Cloze, que avalia a compreensão em leitura, e foram consideradas ainda, como desempenho, as notas escolares nas disciplinas de Português e Matemática. Os resultados revelaram que os alunos cujo conceito escolar era Em processo (conceito mínimo) também foram aqueles que demonstraram menor compreensão em leitura, com nível instrucional com aproveitamento de $47,5 \%$. Os alunos com conceito mediano, denominado Realiza, estavam no nível instrucional com $54,7 \%$ de aproveitamento e aqueles que apresentaram o conceito Realiza plenamente (conceito máximo) acertaram em média $60,2 \%$, demonstrando compreensão independente. Os dados obtidos demonstram que alunos que apresentaram melhor compreensão textual também apresentavam desempenho escolar mais satisfatório em ambas as disciplinas.

Esses resultados geram preocupações, pois o baixo rendimento acadêmico pode ser considerado, como já descrito, um fator de risco à aprendizagem e ao desenvolvimento da criança, podendo acometer outras instâncias, como a família, o relacionamento interpessoal com colegas, entre outros.

\section{Baixo rendimento acadêmico e problemas de comportamento}

Entre os fatores associados ao baixo rendimento acadêmico está o problema de comportamento. O termo "problema de comportamento" gera controvérsias quanto a sua definição. Bolsoni-Silva \& Del Prette (2003), em um estudo acerca da terminologia "problema de comportamento", apontaram duas vertentes principais: o modelo médico ou biológico, que aborda o assunto prioritariamente em termos de sintomas, e, de outro lado, aqueles que compreendem a categoria mais funcionalmente, analisando-os em termos de déficits e excessos comportamentais. A partir dessa segunda compreensão, Bolsoni-Silva (2003) analisa os problemas de comportamento como prejudiciais à interação das crianças com pares e com adultos de sua 
convivência. Nesse sentido, eles podem dificultar que as crianças tenham acesso a diversos ambientes, os quais permitiriam a aquisição de novas habilidades, como, por exemplo, as acadêmicas.

O excesso comportamental, isto é, comportamentos que ocorrem com grande frequência ou intensidade, pode constituir indícios de quadros psicopatológicos (Bordin, Mari \& Caeiro, 1995), interferindo em áreas diversas da vida da criança, inclusive no relacionamento interpessoal, como sugere o estudo realizado por Bandeira et al. (2006), envolvendo 257 estudantes de $1^{\mathrm{a}}$ a $4^{\mathrm{a}}$ série do Ensino Fundamental e 12 professores, cujo objetivo foi obter características sociodemográficas para a ocorrência de comportamentos problemáticos e suas relações com as habilidades sociais e dificuldades acadêmicas. Os resultados mostraram que a frequência de comportamentos problemáticos foi menor em crianças que apresentaram um nível mais adequado e elaborado de habilidades sociais. Sendo assim, os alunos que apresentavam mais problemas de comportamento teriam um repertório social menos habilidoso, o que poderia afetar suas relações interpessoais.

Muitos estudos sobre avaliação comportamental de estudantes envolvem a avaliação de pais e professores e alguns deles procuram investigar relações entre problemas de comportamento e o rendimento acadêmico, como o de Graminha \& Santos (2005). As autoras compararam as características comportamentais de um grupo de crianças com baixo rendimento e de outro com alto rendimento acadêmico, com base nas avaliações de pais e professores. Elas buscavam identificar, em cada grupo, a incidência de problemas emocionais e/ou comportamentais e os tipos de problemas de comportamento que apareceriam associados ao desempenho escolar. Avaliaram quarenta crianças de $1^{\mathrm{a}}$ e $2^{\mathrm{a}}$ série do Ensino Fundamental, sendo vinte classificadas pelos professores como tendo baixo rendimento acadêmico e outras vinte com alto rendimento acadêmico. Utilizaram a Escala de Comportamento Infantil de Rutter A2 (Graminha, 1998), para pais, e a Escala B de Rutter (Santos, 2002), para professores, as quais avaliam problemas emocionais e comportamentais. Os resultados apontaram que, para os pais, $61 \%$ das crianças com baixo rendimento 
apresentaram distúrbios emocionais ou comportamentais, e para o grupo com alto rendimento acadêmico, essa avaliação ocorreu para apenas $21 \%$ das crianças. O mesmo resultado foi obtido com os professores, mas a porcentagem foi maior, sendo que $70 \%$ dos alunos com baixo rendimento acadêmico foram avaliados como apresentando distúrbios emocionais ou comportamentais, e apenas $5 \%$ dos alunos considerados com alto rendimento acadêmico apresentaram esses distúrbios, o que demonstra que a avaliação de pais e professores foi concordante.

Tendo em vista os aspectos mencionados, é importante identificar os comportamentos tidos como inadequados e os recursos da criança e de seu ambiente que podem contribuir para o planejamento e a elaboração de intervenção, aumentando a probabilidade de resultados eficazes (Pinheiro, Del Prette \& Del Prette, 2009).

Destaca-se, em uma perspectiva comportamental, que os problemas de comportamento, embora prejudiciais para a criança e para as pessoas significativas para ela, são mantidos porque têm um propósito para o indivíduo: produzir reforçadores (Sturmey, 1996). Para Rosales-Ruiz \& Baer (1997), uma definição funcional ajuda a identificar se o comportamento é problema ou não. Permite verificar o quanto ele impede a criança de entrar em contato com outras contingências reforçadoras, o que, por sua vez, irá dificultar a aquisição de habilidades promotoras de desenvolvimento. Mesmo que não haja um consenso sobre os fatores influentes no surgimento de problemas de comportamento, parece pertinente entender o fenômeno enquanto multideterminado, sendo as práticas educativas dos professores uma variável a ser considerada, dado o seu papel para a ocorrência dos comportamentos de seus alunos, seja punindo ou reforçando.

Problemas de comportamento, resultado muitas vezes da relação estabelecida entre professores e alunos ou, ainda, entre alunos e outros adultos significativos presentes no sistema escolar, podem ter, como resultado, influência no desempenho acadêmico. Avaliar o desempenho acadêmico e as expectativas dos professores com relação a ele e ao comportamento do aluno auxilia a compreensão de algumas das muitas variáveis presentes no cenário escolar. 


\section{Avaliação do professor, rendimento acadêmico e problemas de comportamento}

No que se refere à escola, o professor é um dos adultos mais significativos para a criança, e a qualidade da interação estabelecida entre ambos, a percepção que o docente tem acerca do processo de ensino-aprendizagem, bem como a expectativa sobre o desempenho e o comportamento de seu aluno, podem influenciar o aproveitamento escolar.

No que se refere à interação entre professor e aluno, temos que os docentes reconhecem a importância das relações humanas na escola, conforme aponta pesquisa realizada por Campos (2002). Porém, Gama \& Jesus (1994) verificaram, contraditoriamente, que o fracasso escolar, na opinião de professores, é de responsabilidade individual do aluno e de sua família (mais especificamente devido à falta de interesse, ao pouco esforço e às condições econômicas de seus integrantes). Nesse estudo, os alunos considerados como menos inteligentes não apenas geravam expectativas de que seu desempenho final seria baixo, como também eram sistematicamente reprovados.

Esses dados concordam com os obtidos por Paiva \& Del Prette (2009) em estudo que tinha como um dos objetivos analisar as características do padrão de crenças de 33 professores acerca dos fatores considerados predominantemente como dificultadores do desempenho escolar dos alunos e dos fatores predominantemente facilitadores. Os resultados mostraram que as professoras concordam mais com a influência das relações interpessoais sobre o desenvolvimento socioemocional do que sobre o desenvolvimento intelectual dos alunos. Em relação às situações de fracasso escolar (em que alunos fazem mal uma lição, $81,82 \%$, ou em que tiram uma nota baixa, $60,61 \%)$, a causa predominantemente atribuída pelas professoras nas situações foi a Falta de capacidade do aluno, o que caracteriza a visão de que o problema está no aluno.

A culpabilização do aluno por parte do professor diante de seu baixo rendimento é motivo de atenção, como aponta Collares (1995), pois em $94,1 \%$ dos casos são confirmadas as atitudes premonitórias 
e a previsão dos professores, feitas no primeiro bimestre letivo, em relação aos alunos que não aprenderão e serão reprovados.

Essa percepção do professor foi considerada por estudos envolvendo a avaliação formal e testes de desempenho padronizados, como o realizado por Capellini, Tonelotto \& Ciasca (2004). Para tanto, participaram 164 alunos do Ensino Fundamental, de ambos os sexos, divididos em dois grupos, segundo a opinião da professora: um formado por alunos com desempenho acadêmico normal, e outro, por alunos abaixo da média. Todos os alunos responderam ao TDE. Os resultados revelaram que as médias do grupo definido pela professora com desempenho inferior foram abaixo do esperado e diferiram significativamente daquelas do grupo de desempenho normal.

Henrique \& Januário (2006) também analisaram a relação entre o desempenho do aluno e a expectativa do professor por meio de um estudo descritivo que avaliou 186 alunos de $6^{\mathrm{a}}$ e $8^{\mathrm{a}}$ séries e dez professores. O desempenho dos alunos foi medido por meio de testes padronizados, e a percepção pessoal do aluno e as expectativas do professor foram obtidas por meio da técnica de autorrelato. A estatística da análise da congruência entre as variáveis em estudo mostrou que a competência percebida pelos alunos tem forte associação positiva, tanto com o seu desempenho como com as expectativas do professor.

Além da correspondência entre a percepção do professor e o desempenho do aluno, há estudos que demonstram relação semelhante envolvendo o problema de comportamento. Feitosa, Del Prette \& Loureiro (2007), em dois estudos de correlação realizados com 49 crianças de São Paulo (SP) e 22 de Cacoal (RO), compararam a avaliação de professores sobre a competência acadêmica dos alunos com uma avaliação direta de desempenho acadêmico, também se utilizando da Escala de Competência Acadêmica do Social Skills Rating System (SSRS-BR), que também mede a presença de comportamentos problemáticos. Os resultados mostraram que os indicadores de competência acadêmica foram correlacionados positivamente entre si e negativamente com problemas de comportamento, concluindose pela acurácia do professor. 
Correia \& Rodrigues (2007) também procuraram investigar o rendimento acadêmico de alunos e a emissão de comportamentos problemáticos avaliados por professores. Para tanto foram selecionadas seis professoras do Ciclo I, do Ensino Fundamental (da $1^{\mathrm{a}}$ à $4^{a}$ série), de uma escola pública estadual, as quais indicaram para compor o grupo de alunos indicados (GI) cinco alunos que, em sua opinião, apresentam problemas de comportamento, e foram sorteados cinco alunos para compor o grupo de alunos sorteados (GS). Uma das professoras indicou apenas dois alunos e teve outros dois sorteados, totalizando 54 alunos de ambos os sexos com idade entre sete anos e 11 meses e 12 anos e oito meses. Para a avaliação, foram utilizadas as notas oficiais do $1^{\circ}$ bimestre e o TDE. Os resultados indicaram que o GS apresentou melhor desempenho que o GI, tendo em vista o desempenho geral obtido no TDE. Porém, a maioria dos alunos ficou com desempenho abaixo da média esperada para sua série ( $89 \%$ dos alunos do GI e 74\% do GS). No entanto, tal resultado diferiu da avaliação do $1^{\circ}$ bimestre realizada pelas professoras, na qual a maioria dos participantes de GI se encontrava dentro da faixa média ( $59 \%$ do GI e 44\% do GS), sendo que 44\% dos alunos do GS foram classificados com desempenho superior, sugerindo diferença entre a avaliação das professoras e a do TDE.

Diante do exposto, temos que o período escolar pode contribuir para o desenvolvimento e a aprendizagem infantil, porém existem variáveis que podem atuar no sentido de favorecer ou dificultar a aquisição de repertórios da criança e que vão se refletir não só no rendimento acadêmico, mas também em outros contextos, como, por exemplo, na família e em outras relações estabelecidas fora desse ambiente.

Acerca do problema de comportamento, é consenso de que este afeta o rendimento acadêmico, a interação entre aluno e entre pares, criando um círculo vicioso que pode levar à evasão, à repetência, à perda de autoestima etc. Porém, como já apresentado, alguns fatores podem contribuir ou dificultar os relacionamentos e o desempenho escolar. Identificá-los e analisá-los em termos funcionais possibilita planejar e executar ações que possam alterar esse quadro 
disfuncional que envolve o aluno emissor de comportamento problemáticos. É necessário, no entanto, auxiliar o professor nessas ações por meio de melhorias nos cursos de formação e atualização, ampliando assim sua concepção e mostrando a ele a interdependência entre os comportamentos dele e o de seus alunos.

Assim, o objetivo desta pesquisa foi descrever e avaliar o desempenho acadêmico de alunos indicados por seus professores como apresentando problemas de comportamento e de alunos sorteados entre o restante da sala, em dois momentos: antes e depois de um curso sobre manejo de problema de comportamento ofertado aos professores.

\section{Método}

\section{Participantes}

Participaram deste estudo quarenta alunos, com idade média de 9,2 anos, que frequentavam as séries iniciais do Ensino Fundamental, e suas respectivas professoras, totalizando quatro docentes de uma escola estadual de Ensino Fundamental (da $1^{\mathrm{a}}$ à $8^{\mathrm{a}}$ série) de um município do interior do estado de São Paulo.

\section{Local}

As atividades pertinentes ao projeto, como a coleta de dados, assim como o curso ofertado, foram realizadas nas dependências da escola na qual os participantes atuavam, em uma sala apropriada cedida pela direção da escola. A escola do Ensino Fundamental funcionava no período da manhã. No Ciclo I havia cinco turmas, das quais quatro foram participantes, pois o professor da quinta turma não participou do curso proposto, não sendo tal turma considerada para este trabalho. 


\section{Materiais}

Para a avaliação do rendimento acadêmico foi utilizado o Teste de Desempenho Escolar - TDE (Stein, 1994), um instrumento que busca oferecer, de forma objetiva, uma avaliação das capacidades fundamentais para o desempenho escolar em escrita, Aritmética e leitura, para crianças que cursam da $1^{\mathrm{a}}$ à $6^{\mathrm{a}}$ série do Ensino Fundamental. É constituído por três subtestes: 1 - Escrita, que avalia a escrita do próprio nome e de palavras isoladas apresentadas sob a forma de ditado; 2 - Aritmética, que avalia a capacidade de solucionar oralmente problemas e realizar cálculos de operações aritméticas por escrito; 3 - Leitura, que mede o reconhecimento de palavras isoladas de contexto. Os subtestes são distribuídos em ordem crescente de dificuldade, independente da série. Ao final, os escores brutos são convertidos e classificados em superior, médio e inferior.

Para a avaliação do problema de comportamento, foi utilizado a Escala de Comportamento Infantil - B de Rutter para professores (ECI - adaptação de Santos, 2002). Essa escala é composta por 26 afirmativas e o professor deve assinalar, para cada uma delas: se a criança com certeza apresenta o comportamento descrito pela afirmação "certamente se aplica", valendo dois pontos; se a criança apresenta o comportamento em menor grau ou menos frequentemente, assinalando "se aplica um pouco", o que corresponde a um ponto; ou se a criança não apresenta o comportamento, fazendo jus ao "não se aplica", valendo zero ponto. Os escores obtidos com essa escala variam de zero até 52 pontos, sendo que, se a somatória dos pontos atingir valores iguais ou acima de nove, há indicação clínica para atendimento psicológico.

\section{Procedimento}

Inicialmente, foram contatadas a direção da escola e os professores, para explicar-lhes os objetivos do projeto e obter o consentimento livre e esclarecido daqueles. Após o aceite, os pais foram informados por meio de carta, para a obtenção da autorização da participa- 
ção das crianças. Em seguida, os professores foram solicitados a indicar, dentre os alunos de sua sala, cinco que apresentavam problemas de comportamento. Estes fariam parte do grupo de alunos indicados (GI). Após as indicações, foram sorteados dentre os demais alunos da sala outros cinco, que comporiam o grupo de aluno, sorteados (GS).

A primeira aplicação do TDE, denominada aqui de Etapa I, aconteceu durante o mês de abril, e nela os professores responderam à ECI, e os alunos, ao TDE. Entre os meses de maio e outubro ocorreu a Etapa II, em que os professores participaram de um curso intitulado "O manejo comportamental em sala de aula". Esse curso foi divido em temas focais distribuídos ao longo de dez sessões presenciais, com duração de duas horas cada, e dez horas de atividades práticas/complementares, totalizando trinta horas. Foi desenvolvido em horários de HTPCs, o que caracteriza a formação em serviço, uma vez que, apesar dos temas focais sobre manejo comportamental, o pequeno número de participantes possibilitou a discussão de dificuldades inerentes ao seu fazer na relação com os alunos. $\mathrm{O}$ curso foi parte do Programa de Extensão da Faculdade de Ciências (Proex) da Unesp - Bauru, na modalidade Atualização/Aperfeiçoamento. A Etapa III aconteceu no mês de novembro, e os alunos responderam novamente ao TDE, e os professores, à ECI.

\section{Resultados}

Inicialmente serão apresentados os dados obtidos na Etapa I, seguidos da Etapa III, e em um terceiro momento serão apresentadas as associações obtidas entre as duas.

Os dados obtidos na Etapa I, com a aplicação da ECI respondida pelos professores, possibilitaram a verificação da presença de problemas de comportamento nos dois grupos, o indicado (GI) e o sorteado (GS). Os resultados apontaram para uma frequência maior de problemas de comportamento no GI. Em valores brutos, nessa etapa, o GI obteve a média de 11,4 pontos na escala, sendo que uma 
pontuação de nove pontos já é uma indicação para encaminhamento clínico da criança, pois há um excesso de comportamentos ou de frequência de problemas que podem interferir de maneira significativa no desenvolvimento da criança. Para o GS, a média de problemas de comportamento foi menor, 3,37 pontos. A análise estatística utilizando o teste Wilcoxon indicou que o GI apresenta consideravelmente mais problemas de comportamento do que o GS, com valor para $p$ igual a 0,002 .

O desempenho escolar obtido com a aplicação do TDE, na Etapa I, indicou que as crianças do grupo de alunos sorteados obtiveram melhores resultados do que os alunos do grupo GI. A Tabela 1 apresenta a média dos valores brutos obtidos no TDE e em seus subtestes para cada grupo nesta etapa.

Tabela 1 - Valor das médias obtidas pelos grupos em relação ao TDE Total, Escrita, Aritmética e Leitura na Etapa I

\section{TDE TOTAL ESCRITA ARITMÉTICA LEITURA}

\begin{tabular}{ccccc}
\hline GI & 49,08 & 10,6 & 9,6 & 27,28 \\
GS & 80,75 & 18,54 & 14,63 & 50,79 \\
\hline
\end{tabular}

Na Etapa III, realizada após a participação no curso, os professores responderam novamente à ECI e os alunos do GI foram avaliados como apresentando menos comportamentos problemas. A média do GI foi de 9,1, valor este muito próximo ao limiar da indicação para tratamento clínico (9,0). Porém, o GS teve um ligeiro aumento, sendo sua média nesta etapa de 3,58, mas essa diferença não é significativa. Apesar da melhora do GI, os grupos ainda diferem de maneira significativa, ou seja, o GI continua apresentando mais problemas de comportamentos que o GS, sendo o valor de $\mathrm{p}=0,004$ (teste de Wilcoxon).

O desempenho acadêmico avaliado pelo TDE na Etapa III foi melhor em termos de resultado bruto para os dois grupos, porém o 
GS continuou com médias superiores às do GI, tanto no Total do TDE quanto em seus subtestes, como apresenta a Tabela 2.

Tabela 2-Valor das médias obtidas pelos grupos em relação ao TDE Total, Escrita, Aritmética e Leitura na Etapa III

TDETOTAL ESCRITA ARITMÉTICA LEITURA

\begin{tabular}{ccccc}
\hline GI & 59,12 & 12,28 & 11 & 36,12 \\
GS & 91,38 & 20,33 & 15,38 & 54,75 \\
\hline
\end{tabular}

OTDE, além de sua pontuação bruta, fornece também uma classificação baseada na média esperada para a série da criança, conforme apresenta a Figura 1. Observa-se que tanto na Etapa I como na Etapa III, a maioria dos alunos, independente do grupo, teve um desempenho considerado inferior à média esperada para sua série. Os dados mostram que mais de $80 \%$ do GI e de $60 \%$ do GS obtiveram classificações inferiores à média na Etapa I, no Total ou nos subtestes. No GI, o melhor desempenho foi em Escrita, e o pior, em Leitura. Já no GS, o melhor foi em Escrita, e o pior, em Aritmética.

\section{PERCENTUAL DA CLASSIFICAÇÃO DOS GRUPOS NO TDE}

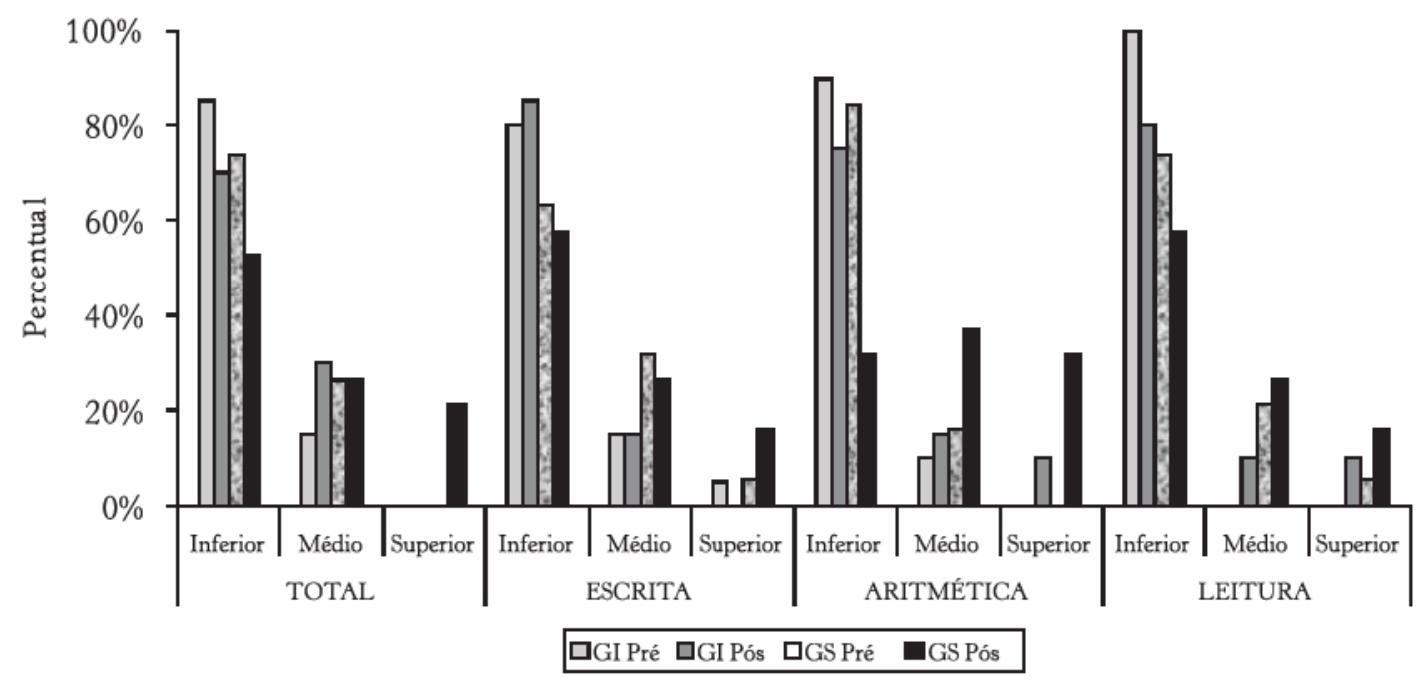

Figura 1 - Distribuição do percentual da classificação do desempenho dos alunos por grupo no TDE nas Etapas I e III (pré e pós) 
Na Etapa III, ambos os grupos melhoram sua média, porém cerca de $70 \%$ dos alunos do GI permaneceram classificados com desempenho inferior à média esperada para sua série, sendo o pior desempenho do grupo no subitem Escrita. Já no GS, menos de 60\% dos alunos foram classificados com desempenho inferior no Total ou nos subtestes do TDE.

Comparações intra e intergrupos foram conduzidas considerando o desempenho dos grupos nas duas etapas (I e III). Nas análises conduzidas intragrupo, o desempenho dos dois grupos melhorou significativamente da Etapa I para a Etapa III. As análises estatísticas desses dados estão apresentadas na Tabela 3. Todavia, a comparação intergrupos em cada uma das etapas aponta para desempenho significativamente pior do GI na Etapa I em uma das avaliações conduzidas (em Leitura), e na Etapa III observam-se diferenças significativas em duas das quatro análises conduzidas, no desempenho Total e em Aritmética, com melhor desempenho do GS.

Tabela 3 - Valor da significância das comparações dos grupos nas Etapas I e III

\begin{tabular}{lcccc}
\hline & $\begin{array}{c}\text { GI } \\
\text { Etapa I E Etapa III } \\
\text { valor de } p\end{array}$ & $\begin{array}{c}\text { GS } \\
\text { Etapa I x Etapa III } \\
\text { valor de } p\end{array}$ & $\begin{array}{c}\text { GI x GS } \\
\text { Etapa I }\end{array}$ & $\begin{array}{c}\text { GI x GS } \\
\text { Etapa III }\end{array}$ \\
\hline TDE-Total & 0,00013 & 0,0008 & n.s.* & 0,033 \\
TDE-Escrita & 0,00766 & 0,0223 & n.s. & n.s. \\
TDE-Aritmética & 0,00085 & 0,0012 & n.s. & 0,030 \\
TDE-Leitura & 0,00059 & 0,0114 & 0,021 & n.s. \\
\hline
\end{tabular}

*n.s. = não significativo

\section{Discussão}

A análise da avaliação do desempenho de alunos, sob o ponto de vista de seus professores, indicados como apresentando comportamento problemáticos e de outro grupo de alunos sorteados, antes e 
depois de um curso sobre manejo comportamental, apontou para a correspondência entre a indicação de aluno com problemas de comportamento e o resultado na ECI-B. Essa capacidade do professor de identificar os problemas de comportamento também foi encontrada por Feitosa, Del Prette \& Loureiro (2007), com resultados que mostraram que indicadores de competência acadêmica foram correlacionados negativamente com problemas de comportamento.

Na Etapa I, o GI também apresentou resultados brutos, na avaliação do TDE, menores que os apresentados pelo GS, sendo a diferença significativa apenas no subteste Leitura. Esse fato deve ser foco de atenção, pois, como apontam Oliveira, Boruchovitc \& Santos (2008), a habilidade de leitura pode ser considerada como preditora do desempenho em Aritmética e Português. Defasagens dessa habilidade podem influenciar desempenhos futuros da criança. Mas como podemos observar na Etapa III, o GI melhorou seu desempenho, e embora com resultado bruto menor que o GS, essa diferença não é mais significativa. Porém, as diferenças favorecem o GS no subteste Aritmética e no Total do TDE.

Vale aqui ressaltar outro dado. Na Etapa III, ambos os grupos tiveram melhoras no Total e nos subtestes do TDE, as quais foram significativas. Mas, como apresentado, em ambas as etapas, mais de $50 \%$ dos alunos continuaram com classificação inferior no TDE. Esse resultado é de preocupação pública e não foi diferente dos resultados encontrados por Dias, Enumo \& Turini (2006), quando alunos avaliados após um ano, embora ampliassem seu repertório, não apresentavam melhora suficiente para mudar sua classificação de inferior para médio ou superior no TDE. Correia \& Rodrigues (2007) também identificaram que a maior parte dos alunos classificados no TDE com desempenho inferior obteve de seus professores nota bimestral dentro da média, sugerindo divergências entre a avaliação escolar e o TDE. Vale ressaltar que as notas bimestrais não foram consideradas neste estudo e pode-se sugerir que em pesquisas futuras seja investigada essa variável.

Com relação à avaliação dos problemas de comportamento na Etapa III, os grupos continuaram diferindo significativamente, mas 
os resultados brutos sugerem que houve diminuição na presença e/ ou frequência de comportamentos problemáticos. No GI, a média diminuiu para 9,1, valor esse muito próximo ao limite para indicação para tratamento clínico. Provavelmente esse resultado seja decorrente da participação das professoras no curso, durante a Etapa II, o que proporcionou um repertório para melhor planejamento e execução das atividades, bem como auxiliou na condução dos comportamentos problemas por meio de técnicas precedidas pela análise do comportamento, assim como sugerem Pinheiro, Del Prette \& Del Prette (2009).

Enfim, os resultados do presente trabalho indicaram que alunos que apresentaram problemas de comportamento na avaliação de seu professor tiveram mais chances de ter um rendimento acadêmico prejudicado, tanto no começo do ano letivo quanto no final. Isso deve ser foco de atenção, como apontam as pesquisas na área (Gam \& Jesus, 1994; Collares, 1995; Graminha \& Santos, 2005). Os efeitos do fracasso escolar podem ser considerados fatores de risco ao desenvolvimento da criança, acompanhando-a ao longo dos anos e interferindo em outros contextos, como escola e família. Porém, os dados sugerem que problemas de comportamento dos alunos podem ser alterados ao longo do ano. Neste estudo, a melhora pode se dever à participação dos professores em um curso de atualização ocorrido na própria escola, no sentido de incrementar em seu repertório habilidades focadas para a questão. No entanto, sugerimos estudos com grupos cujos professores não passaram pela atualização (Grupo Controle), para que se realizem comparações e afirmações mais fidedignas sobre sua eficácia.

\section{Referências bibliográficas}

BANDEIRA, M et al. Comportamentos problemáticos em estudantes do Ensino Fundamental: características da ocorrência e relação com habilidades sociais e dificuldades de aprendizagem. Estudos de Psicologia, v.11, n.2, p.199-208, 2006. 
BRAGANÇA, B.; FERREIRA, L. A. G.; PONTELO, I. Práticas educativas e ambientes de aprendizagem escolar: relato de três experiências. $1^{\circ}$ Seminário Nacional de Educação Profissional e Tecnológica. Belo Horizonte, MG, 2008.

BOLSONI-SILVA, A. T. Habilidades sociais educativas, variáveis contextuais e problemas de comportamento: comparando pais e mães de pré-escolares. Dissertação (Doutorado), Universidade de São Paulo, Ribeirão Preto, 2003.

; DEL PRETTE, A. Problemas de comportamento: um panorama da área. Revista Brasileira de Terapia Comportamental e Cognitiv., v.5, n.2, p.91-103, 2003.

BORDIN, I. A. S.; MARI, J. J.; CAEIRO, M. F. Validação da versão brasileira do "Child Behavior Checklist" (CBCL) (Inventário de Comportamentos da Infância e Adolescência): dados preliminares. Revista ABP-APAL, v.17, p.55-66, 1995.

CAMPOS, M. M. Consulta sobre a qualidade da educação na escola. Relatório técnico final. São Paulo: Fundação Carlos Chagas, 2002. CAPEllini, S. A., TONELOTTO, J. M. de F.; CiASCA, S. M. Medidas de desempenho escolar: avaliação formal e opinião de professores. Estudos de Psicologia, Campinas, v.21, n.2, p.79-90, 2004. COLLARES, C. A. L. O cotidiano escolar patologizado: espaço de preconceitos e práticas cristalizadas. Dissertação (livre docência). Faculdade de Educação, Departamento de Psicologia Educacional, Universidade Estadual de Campinas, Campinas, SP, 1995.

CORREIA, L. M. Problematização das dificuldades de aprendizagem nas necessidades educativas especiais. Análise Psicológica, v.2, p.36976, 2004.

CORREIA, M. R. G.; RODRIGUES, O. M. P. R. Problemas de comportamento e a avaliação de alunos por seus professores. I Simpósio da Pós Graduação em Psicologia do Desenvolvimento e Aprendizagem. Bauru, SP, 2007.

DIAS, T. L.; ENUMO, S. R. F; TURINI, F. A. Avaliação do desempenho acadêmico de alunos do ensino fundamental em Vitória, Espírito Santo. Estudos de Psicologia, Campinas v.23, n.4, p.381-90, 2006.

FEITOSA, F. B.; DEL PRETTE, Z. A.; LOUREIRO, S. R. Acuracidade do professor na identificação de alunos com dificuldade de aprendizagem. Temas em Psicologia, v.15, n.2, p.237-47, 2007. 
GAMA, E. M. P.; JESUS, D. M. Atribuições e expectativas do professor: representações sociais na manutenção da seletividade social na escola. Psicologia: teoria e pesquisa, v.10, n.3, p.393-410, 1994.

GRAMINHA, S. S. V. Recursos metodológicos para pesquisas sobre riscos e problemas emocionais e comportamentais na infância. In: ROMANELLI, G; BIASOLI-ALVEZ, Z. M. M. (Orgs.). Diálogos metodológicos sobre práticas de pesquisa. Ribeirão Preto: Legis Summa, 1988, p.71-85.

; SANTOS, P. L. Problemas emocionais e comportamentais associados ao baixo rendimento acadêmico. Estudos de Psicologia, v.11, n.1, p.101-9, 2005.

HENRIQUE, J.; JANUÁRIO, C. A competência percebida pelos alunos, as expectativas do professor e o desempenho académico: como se relacionam na disciplina de educação física? Revista Portuguesa de Ciências do Desporto, v.6, n.2, p.194-204, 2006.

OKANO, C. B, et al. Crianças com dificuldades escolares atendidas em programa de suporte psicopedagógico na escola: avaliação do autoconceito. Psicologia, reflexão e crítica, v.17, n.1, p.121-8, 2004.

OLIVEIRA, K. L.; BORUCHOVITC, E.; SANTOS, A. A. A. Leitura e desempenho escolar em Português e Matemática no Ensino Fundamental. Paideia, v.18, n.41, p.531-40, 2008.

PACHECO, L. M. B. Diagnóstico de dificuldade de aprendizagem. Temas psicologia, v.13, n.1, p.45-51, 2005.

PACHECO, L.; SISTO, F. F. Ajustamento social e dificuldade de aprendizagem. PSIC - Revista de Psicologia, Vetor Editora, v.6, n.1, p.43-50, 2005.

PAIVA, M. L. M. F.; DEL PRETTE, Z. A. P. Crenças docentes e implicações para o processo de ensino-aprendizagem. Revista semestral da Associação Brasileira de Psicologia Escolar e Educacional (Abrapee), v.13, n.1, p.75-85, 2009.

PEREIRA, M. E. M.; MARINOTTI, M.; LUNA, S. V. O compromisso do professor com a aprendizagem do aluno: contribuições da Análise do Comportamento. In: HUBNER, M. M. C; MARINOTTI, M. (Orgs.). Análise do Comportamento para a educação: contribuições recentes. Santo André: Esetec, 2004, p.11-32.

PINHEIRO; M. L. S.; DEL PRETTE, A.; DEL PRETTE, G. Crianças com problemas de comportamento: uma proposta de intervenção via treinamento em grupo de pais. In: HAASE, F. V. G; FERREI- 
RA, O; PENNA, J. F. (Orgs.). Aspectos biopsicossociais da saúde na infância e adolescência. Belo Horizonte: Coopmed, 2009, p.523-35. ROSALES-RUIS, J.; BAER, D. M. Behavioral cusps: a developmental and pragmatic concept for behavior analysis. Journal of Applied Behavior Analysis, v.30, p.533-44, 1997.

SANTOS, P. L. Riscos e recursos em crianças com alto e baixo rendimento acadêmico: um estudo comparativo. Dissertação (Doutorado). (Ribeirão Preto: Universidade de São Paulo; 2002.

STEIN, L. M. TDE: Teste de Desempenho Escolar. São Paulo: Casa do Psicólogo, 1994.

STURMEY, P. Functional analysis in clinical psychology. England: John Wiley \& Sons, 1996. 

PARTe II

\section{Aplicações da Análise do COMPORTAMENTO NA EDUCAÇÃO}





\title{
7
}

\section{ANÁLISE EXPERIMENTAL DAS RELAÇÕES ENTRE O OUVIR E O FALAR EM DEFICIENTES AUDITIVOS IMPLANTADOS COCLEARES ${ }^{1}$}

\author{
Fernanda Luz Anastacio Pessan ${ }^{2}$ \\ Fabiana Cristina de Souza ${ }^{3}$ \\ Bruna Mares Terra ${ }^{4}$ \\ Luiza Quadros Kutlesa Catunda ${ }^{5}$ \\ Ana Claudia Moreira Almeida Verdu ${ }^{6}$ \\ Maria Cecília Bevilacqua ${ }^{7}$
}

\section{Introdução}

Uma interface recente com as pesquisas sobre processos da audição e de (re)habilitação pelo implante coclear tem sido realizada pela Análise do Comportamento por meio de pesquisas sobre controle de estímulos. O modelo de investigação tem sido o paradigma das relações de equivalência, um comportamento emergente que é observado quando são ensinadas pelo menos duas relações condicionais com um elemento em comum. Um dos procedimentos de ensino cuja ca-

1 Capítulo escrito com base nas investigações conduzidas em nível de iniciação científica e mestrado, sob a orientação da quinta e sexta autoras. Projeto apoiado pelo Instituto Nacional de Ciência e Tecnologia, Estudos sobre Comportamento, Cognição e Ensino CNPq: \#573972/2008-7/Fapesp: \#2008/57705-8.

2 Programa de Pós-Graduação em Psicologia do Desenvolvimento e Aprendizagem da Unesp - Bauru.

3 Graduação. Departamento de Psicologia, Unesp - Bauru.

4 Programa de Pós-Graduação em Psicologia do Desenvolvimento e Aprendizagem da Unesp - Bauru.

5 Idem.

6 Idem.

7 Pós-Graduação em Fonoaudiologia e Centro de Pesquisas Audiológicas, Universidade de São Paulo, USP, Bauru. 
pacidade é gerar, sem ensino direto, relações de equivalência é o emparelhamento-de-acordo-com-o-modelo, em que um estímulo auditivo é emparelhado a dois ou mais estímulos visuais e a tarefa do participante é selecionar o que vai com o modelo. O emparelhamento auditivo-visual com ouvintes geralmente ocasiona a nomeação das figuras, entretanto, usuários de implante apresentam dificuldade em nomear, mesmo depois de apresentarem desempenho preciso nas tarefas de seleção. Essa diferença na velocidade de aquisição corrobora a ideia de que os operantes verbais são funcionalmente independentes, isto é, o estabelecimento de um não necessariamente é acompanhado de outro. O objetivo deste capítulo é descrever operantes verbais e apresentar os aspectos gerais do paradigma das relações de equivalência, bem como sua aplicação na investigação das condições necessárias e suficientes para a emergência de modos ativos e receptivos de linguagem em deficientes auditivos. Considerando os modos ativos de linguagem, a fala inteligível, têm sido empregados diferentes procedimentos de modelagem de controle de estímulos e resposta vocal que são apresentados juntamente com relato de pesquisas concluídas e em andamento.

\section{Linguagem e comportamento verbal}

No escopo da Análise do Comportamento, o termo comportamento verbal tem sido usado, em vez de linguagem, por considerar sua determinação ambiental, pois compartilha das propriedades definidoras de qualquer comportamento operante. O comportamento verbal modifica o ambiente e é modificado por suas próprias consequências (Skinner, 1957). Sua aquisição não é orientada por aquilo que ocorre na interioridade do sujeito, mas pelos determinantes do comportamento na exterioridade, pela ação do ambiente sobre o organismo (Passos, 2003).

A aquisição do repertório verbal inicia já em crianças muito pequenas. No bebê, a princípio, há apenas reações instintivas. $\mathrm{O}$ balbucio, de início, é apenas uma reação fisiológica e, posteriormente, 
pelas implicações que tem sobre a mãe e pessoas próximas, passa a ter função de comunicação (Goldfeld, 2002). A criança, então, aprende a nomear objetos e aos poucos nomeia as propriedades desses objetos, expandindo seu repertório pelas recombinações de unidades já aprendidas (Galvão \& Barros, 2001).

O comportamento verbal é operante por também alterar o ambiente e sofrer as alterações por ele promovidas. Nesse caso, o ambiente que aquele altera não é o mundo físico, mas o comportamento de outra pessoa. Em uma análise funcional, a investigação volta-se para os reforçamentos mantidos pela comunidade verbal, buscando identificar determinantes do comportamento entre ouvinte efalante, pois a audiência controla o falante por meio de reforçamento diferencial, modelando seu comportamento (Skinner, 1957; Galvão \& Barros, 2001).

As categorias de comportamento verbal elementares, controladas por estímulos verbais antecedentes, definidas por Skinner (1957) são: a) ecoico - controlado por um estímulo auditivo antecedente produto da resposta verbal de outrem, tendo como produto uma resposta também audível e se assemelha ponto a ponto com o estímulo antecedente;

b) cópia - cujo antecedente seria um estímulo textual e o produto da resposta, motora, é também um texto e se assemelha, ponto a ponto, com o estímulo antecedente;

c) ditado - tem como antecedente um estímulo auditivo produto da resposta vocal de outrem, controlando uma resposta escrita cuja correspondência é funcional;

d) textual - cujo antecedente seria um texto impresso que evocaria uma resposta vocal com correspondência funcional sem, contudo, indicar leitura com compreensão;

e) intraverbal - no qual um estímulo verbal antecedente controla uma resposta verbal.

Além dos operantes verbais primários controlados por estímulos verbais antecedentes, outras duas classes de operantes verbais primários foram definidas: o tacto e o mando. O tacto, estabelecido e mantido via reforçamento generalizado, apresenta como antece- 
dente discriminativo um objeto ou evento do ambiente. Já o mando tem sua análise funcional vinculada a condições de privação ou estimulação aversiva às quais o organismo pode ser exposto e seu estabelecimento depende de um reforçador específico usualmente embutido na resposta de mandar (Brino \& De Souza, 2005).

Uma das características dos operantes verbais é sua independência funcional, isto é, são estabelecidos e mantidos por contingências de reforçamento independentes, e muitos estudos têm confirmado essa interpretação skinneriana (Cuvo \& Riva, 1980; Eikeseth \& Nesset, 2003; Gaia, 2005; Guess, 1969; McMorrow et al., 1987).

Guess (1969) ensinou o conceito de plural a dois participantes com diagnóstico de síndrome de Down, que não apresentavam esse conceito, mas que articulavam o fonema /s/ pelo procedimento de emparelhamento de acordo com o modelo. A tarefa consistia em selecionar um dentre dois estímulos de comparação, que poderiam ser um único objeto ou pares de objetos, dependendo da palavra falada apresentada (que poderia estar no singular ou no plural).

O procedimento foi desenvolvido em etapas. Na primeira etapa foi ensinada a discriminação (linguagem receptiva) de palavras no singular e no plural. As palavras eram ditadas no singular, e eram apresentados ao participante objetos que ele deveria apontar. Se apontasse um único objeto, o desempenho era considerado correto; se apontasse pares do mesmo objeto, era considerado erro e a mesma tentativa era reapresentada. Em seguida as palavras eram ditadas no plural e os mesmos objetos eram apresentados para o participante, porém o desempenho solicitado era selecionar o par de objetos. Por fim, a sequência de objetos (únicos e pares) era intercalada. Ao longo do ensino também foi avaliada a produção das palavras no plural (nomeação), e o procedimento consistia na apresentação de um único objeto ou de pares de objetos. Os participantes mostraram a discriminação de palavras no singular e no plural que foram treinadas nas tarefas de selecionar objetos quando as palavras eram ditadas (linguagem receptiva). Nenhum participante apresentou produção de palavras no plural. Nesse caso, o treino de linguagem receptiva não ofereceu condições suficientes para a 
produção de tais palavras (as mesmas que haviam sido ditadas pelo experimentador).

Na segunda etapa do estudo de Guess (idem), os participantes foram expostos ao treino direto da produção de palavras no plural e ambos adquiriram a produção das palavras treinadas no singular e no plural. Na terceira etapa, o ensino de repertório receptivo foi repetido, porém revertido: diante de palavras apresentadas no singular foram reforçadas as seleções de pares de objetos, e diante de palavras apresentadas no plural foram reforçadas seleções de objetos únicos. Durante a reversão, também foi conduzida a avaliação da produção de palavras. Os participantes continuaram apresentando a seleção de objetos de acordo com a convenção utilizada, apresentando a seleção do objeto único quando palavras no plural eram ditadas e selecionando pares de objetos quando as ditadas eram palavras no singular. Porém, na avaliação da produção de palavras os participantes apresentaram a expressão correta de plural diante de pares de objetos e de singular diante de objetos únicos.

De acordo com Guess (idem), os resultados indicam que a compreensão da linguagem receptiva era funcionalmente independente da produção de palavras na aquisição do morfema de plural para os dois participantes avaliados. Quando muda a contingência de reforço diante da demanda de linguagem receptiva, muda o repertório apresentado pelos participantes. Porém, como não foi modificada a contingência de reforço para a produção de fala, esse repertório se manteve da mesma forma. Esse estudo demonstra que tanto os repertórios de produção de fala como de linguagem receptiva são estabelecidos e mantidos por contingências de reforço funcionalmente independentes e que a aquisição de um não corresponde necessariamente à aquisição do outro (Skinner, 1957).

A capacidade de discriminação entre estímulos é essencial para a aquisição do repertório verbal vocal e crianças com deficiência auditiva pré-lingual têm essa capacidade inicialmente prejudicada. 


\section{Deficiência auditiva e implante coclear}

A integridade anatomo fisiológica do sistema auditivo é pré-requisito para a aquisição e o desenvolvimento normal da linguagem, uma vez que, dentre outros fatores, faz-se necessário que a criança aprenda a conexão que existe entre os sons da fala e os movimentos dos órgãos fonoarticulatórios que geram esses sons (Boothroyd, 1984).

Nos primeiros anos de idade, é a audição da criança que direciona o desenvolvimento e o controle da aquisição dos fonemas e a compreensão de que a fala é composta por unidades menores. Com o passar dos anos, a criança se baseará mais nas informações dos ajustes motores e proprioceptivos, isto é, como ela deve "sentir" os sons durante a produção da fala (Robbins, 2000).

A deficiência auditiva na infância pode acarretar atrasos na fala e na linguagem, na medida em que interfere em dois processos fundamentais: a recepção dos sons e a habilidade de monitoramento da própria fala (feedback acústico-articulatório). De maneira geral, as alterações de fala e da linguagem são maiores nos casos de perdas auditivas severas e profundas (Moret et al., 2008).

A deficiência auditiva é conhecida como a perda ou limitação na capacidade de ouvir estímulos auditivos. Segundo Bevilacqua (1998), em relação à localização da alteração no ouvido, a deficiência auditiva pode ser classificada como condutiva, quando a alteração está localizada no ouvido externo e/ou no ouvido médio; neurossensorial, quando a alteração está localizada no ouvido interno, no Órgão de Corti ou, ainda, em fibras do nervo auditivo; mista, quando a perda auditiva está no ouvido externo e/ou médio e no interno. Quando a perda auditiva é central, a alteração pode se localizar a partir do tronco cerebral até as regiões subcorticais e no córtex cerebral.

Ainda segundo Bevilacqua (idem), a perda auditiva pode ser classificada quanto ao grau de comprometimento, dado pelos limiares tonais obtidos a partir de testes audiométricos, sendo classificada em leve (perda auditiva com limiares entre 15 e trinta $\mathrm{dB}$ ), modera$\mathrm{da}$ (entre 31 e sessenta $\mathrm{dB}$ ), severa (entre 61 e noventa $\mathrm{dB}$ ) e profun- 
da (acima de noventa dB). De acordo com a época de ocorrência, pode ser pré-lingual (antes do período de aquisição da linguagem) e pós-lingual (depois do período de aquisição da linguagem). Quanto à lateralidade, a perda auditiva pode ser classificada em unilateral (acometendo apenas um dois ouvidos) e bilateral (acometendo ambos os ouvidos).

Uma possibilidade de reabilitação da deficiência auditiva severa ou profunda é o implante coclear (IC), um dispositivo eletrônico inserido cirurgicamente na parte interna do ouvido que substitui o órgão sensorial da audição, localizado dentro da cóclea e conhecido como Órgão de Corti. O implante transforma a energia sonora em pulsos elétricos, permitindo que a área do cérebro responsável pela audição seja estimulada, possibilitando, assim, a detecção auditiva, especialmente os sons da fala (idem, ibidem). Contudo, compreender o que se ouve requer aprendizagem pela exposição a novas contingências ambientais sonoras que podem exercer função antecedente e consequente para a emissão de novas respostas verbais. Por sua vez, a emissão de respostas vocais inteligíveis requer discriminação auditiva de sons produzidos pelo falante, além das respostas vocais emitidas pelo próprio ouvinte.

Os componentes internos e externos presentes em alguns modelos de implante coclear estão exemplificados na Figura 1.
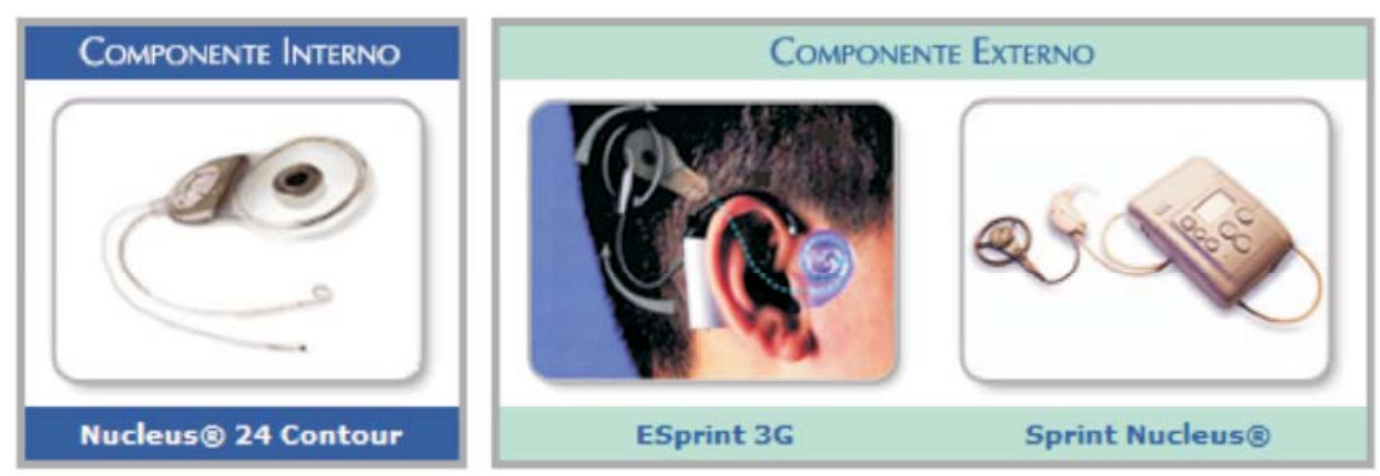

Figura 1 - componentes internos e externos de diferentes modelos de implante coclear. http://www.implantecoclear.com.br/index.php?pagina=modelos (acesso em: jun. 2010). Componentes internos: receptor estimulador com filamento de eletrodos (painel à esquerda). Componentes externos: microfone retro auricular, processador da fala, antena transmissora (painel à direita). 
Existem muitos modelos de implante disponíveis no mercado. Utilizam recursos que permitem manipular o local e a velocidade de estimulação elétrica para definir a estratégia de processamento dos sons da fala. Essa possibilidade de produzir estimulação de modo localizado e variar a velocidade de envio do estímulo permite ao dispositivo reproduzir o modo como o sistema auditivo normal utiliza o espectro da frequência e os padrões temporais do sinal sonoro do meio ambiente, gerando, então, a detecção dos sons ambientais.

As implicações do uso de implante coclear e seus avanços tecnológicos fazem desse dispositivo o recurso mais avançado para o tratamento que visa desenvolver repertório de falante em crianças com deficiência neurossensorial profunda e severa, principalmente entre aquelas acometidas por esse tipo de perda antes do desenvolvimento de linguagem oral (pré-lingual). Porém, o procedimento cirúrgico se configura como uma etapa intermediária entre a avaliação das condições pré-implante e o acompanhamento para a regulagem do implante após seu recebimento (Moret, Bevilacqua \& Costa, 2007).

\section{Pesquisas em controle de estímulos}

Em deficientes auditivos pré-linguais a função auditiva, isto é, os desempenhos de detectar, discriminar, reconhecer, compreender e lembrar ${ }^{8}$ de estímulos sonoros, será estabelecida pela primeira vez a partir da ativação do implante. Contudo, os sons ouvidos são desprovidos de valor semântico. Nesse caso, a compreensão de sons da fala a partir da estimulação elétrica produzida pelo implante requererá aprendizagem. Estudos com crianças pré-linguais indicam que o implante favorece o desenvolvimento da habilidade para se perceber sons e também permite o progresso da linguagem oral, contudo

8 Uma descrição pormenorizada dos desempenhos que envolvem o processamento auditivo (detectar, discriminar, reconhecer, compreender e memorizar) pode ser obtida em Almeida-Verdu, 2002; Moret et al., 2007. 
essas modalidades de desempenho não apresentam o mesmo ritmo (Bevilacqua et al., 2007).

Um dos aspectos relevantes de acompanhamento e investigação a partir de diferentes disciplinas (Audiologia, Fonoaudiologia, Análise do Comportamento, entre outras) é a descrição das condições sob as quais a expansão de repertórios verbais receptivos (ouvir) e expressivos (falar) ocorre em surdos implantados e se estes compartilham de verdadeiras relações simbólicas.

O paradigma da equivalência de estímulos fornece o critério operacional que permite diferenciar a emergência de verdadeiras relações simbólicas de relações condicionais “se-então". Nesse sentido, se, por exemplo, um participante aprende as discriminações auditivo-visuais entre uma palavra ditada e uma figura $(A B)$ e entre a mesma palavra falada e outra figura $(\mathrm{AC}) \mathrm{e}$, posteriormente, demonstra a emergência de relações visual-visual entre as figuras (BC-CB) sem o ensino explícito das relações entre estas, então pode-se dizer que o resultado indica formação de classes de equivalência e verdadeiras relações simbólicas (Sidman \& Talby, 1982).

Da Silva et al. (2006) conduziram o primeiro estudo que aproximou a Análise do Comportamento, mais especificamente o paradigma de equivalência de estímulos, da reabilitação de implantados. Esse estudo teve o objetivo de estender a metodologia das relações de equivalência para o estudo da estimulação elétrica recebida por deficientes auditivos implantados. Duas crianças pós-linguais e duas pré-linguais receberam ensino em relações condicionais entre figuras $(\mathrm{AB}$ e $\mathrm{AC})$ que consistiam em letras gregas exibidas na tela de um microcomputador, e todas demonstraram as relações ensinadas e derivadas, atestando as relações de equivalência (BC e CB). Em seguida, um conjunto de estímulos elétricos foi apresentado, via estimulação direta na cóclea (uma sequência de cinco pulsos de um segundo), e foi conduzido o ensino que estabeleceu novas relações condicionais auditivo-visuais (DC). Foram então testadas as relações de equivalência auditivo-visuais DA e DB. Os resultados dos participantes pós-linguais demonstraram a aprendizagem das relações envolvendo pulsos elétricos (DC) pelo procedimento de empa- 
relhamento de acordo com o modelo, mas não demonstraram a emergência das novas relações auditivo-visuais (DA e DB). Os participantes pré-linguais sequer aprenderam as relações com estímulos elétricos, embora o aspecto promissor do estudo tenha sido a condução da pesquisa em controle de estímulos em rotina de hospital e tenha demonstrado emergência de relações simbólicas visual-visual.

Pesquisas posteriores à de Silva et al. (idem), adotando o mesmo paradigma para estudo do comportamento simbólico com implantados, além das condições que envolvem a aprendizagem do ouvir, realizaram também sondagens sobre o efeito dessa aprendizagem sobre o falar. Os quatro estudos conduzidos por Almeida-Verdu et al. (2008a) avaliaram o potencial de crianças com surdez neurossensorial que receberam o implante coclear exibirem relações de equivalência entre figuras e palavras ditadas pelo procedimento de emparelhamento de acordo com o modelo. Dez crianças com surdez pré-lingual e quatro com surdez pós-lingual foram estudadas e todas aprenderam as relações entre palavra ditada e figuras ( $A B$ e AC) ensinadas, e a maior parte delas demonstrou a formação de classes (BC e CB). Ao final de cada um dos Estudos 1, 2 e 3, foram conduzidos testes de nomeação de figuras, mas as crianças não demonstraram resultados consistentes com os resultados obtidos nos testes de equivalência. De maneira geral, as crianças demonstraram a mesma vocalização para as figuras $(\mathrm{B}$ e $\mathrm{C})$ que foram emparelhadas à mesma palavra ditada (A), porém a vocalização não fazia correspondência ponto a ponto com essa palavra, ditada na fase de ensino.

Outro estudo recente foi o conduzido por Battaglini (2010), que teve como objetivo avaliar se implantados cocleares pré-linguais aprenderiam relações condicionais entre palavra ditada e figura $(A B)$ e entre figura e palavra impressa (BC) via exclusão, e se o aprendizado dessas relações seria condição para a emergência de relações de equivalência para a nomeação de figuras (BD) e de palavras impressas (CD). Excetuando-se uma participante, todos aprenderam as relações ensinadas ( $\mathrm{AB}$ e $\mathrm{AC}$ ) e demonstram formação de classes. Nos pós-testes de nomeação, a maioria dos participantes emitiu vocalizações sem correspondência ponto a ponto à palavra ensina- 
da. Diante disso, discute-se no estudo a possibilidade de que o número de exposições ao estímulo auditivo pode ser uma variável importante para a aprendizagem de novos operantes verbais e a relação que o ouvir estabelece com o falar.

Um estudo que realizou acompanhamento longitudinal da evolução da audição em surdos pré-linguais implantados foi conduzido por Gaia (2005) e avaliou o desempenho de implantados em reconhecimento de palavras (relações condicionais auditivo-visuais), imitação de palavras (comportamento ecoico) e nomeação de figuras após três, seis, nove e 12 meses da ativação do implante coclear. Os resultados mostram um melhor desempenho dos participantes em testes de linguagem receptiva (teste de reconhecimento de palavras) do que os de linguagem expressiva (testes de ecoico e nomeação).

Esses resultados são condizentes com os encontrados pela Audiologia em implantados cocleares e indicam que o fato do ouvir estar estabelecido não é condição suficiente para que o indivíduo seja capaz de falar a palavra que ouve. Em outras palavras, embora o falar dependa do ouvir (o ouvinte precisa detectar uma palavra falada, discriminar entre palavras diferentes, relacionar uma palavra a seus referentes), a fala, seja como nomeação, seja como ecoico, depende de contingências que favoreçam sua aprendizagem, dentre essas destacam-se contingências interacionais do indivíduo com sua comunidade verbal.

Nos estudos apresentados, o ouvir, após uma série de procedimentos (escolha do dispositivo, avaliação de indicação para o implante, ato cirúrgico), tem sido obtido chegando à precisão, mas o falar não o acompanha no mesmo ritmo. Embora a velocidade de aquisição entre o ouvir e o falar também seja observada em crianças ouvintes, ainda não foram demonstradas as condições necessárias para a melhora nesse desempenho em deficientes auditivos pré-linguais. A seguir são apresentados alguns estudos já concluídos e outros em andamento organizados em dois grandes grupos: (a) um grupo que investiga os efeitos da aprendizagem de sucessivas relações auditivo-visuais com diferentes modalidades de estímulo visual (figura, palavra impressa e sílaba) seguidas de verificação da nomeação; (b) 
e outro que investiga os efeitos da modelagem da resposta vocal a partir do ensino de imitação de palavras.

(a) Aprendizagem de sucessivas relações auditivo-visuais seguidas da avaliação da nomeação.

Entre as pesquisas mais recentes conduzidas com implantados, Golfeto (2010) planejou estudos com a finalidade de ampliar vocabulário em sete crianças com deficiência auditiva pré-lingual. Ensinou discriminações condicionais entre palavras ditadas e figuras ( $A B$ ) e entre palavras ditadas e palavras impressas (AC), e foram programados problemas sucessivos de aprendizagem. Ao final, testes de formação de classes foram realizados. Um delineamento de linha de base múltipla entre conjuntos de palavras (passos) foi empregado para aferir os efeitos do procedimento com cada participante, individualmente, ao final de cada passo de ensino. Para isso foram realizados testes de nomeação das palavras e das figuras antes e depois do ensino de cada passo.

Os estudos apresentados por Golfeto (2010) visavam avaliar se o ensino de correspondências entre palavras ditadas e referentes do mundo físico e social afetaria a emergência de novos comportamentos de caráter simbólico. Foi possível afirmar que os participantes têm sido capazes de aprender as relações condicionais diretamente ensinadas e formar classes de estímulos, com uma diminuição no número de exposições aos blocos de ensino ao longo do ensino dos conjuntos de palavras, o que é indicativo de que o desempenho melhora a cada conjunto de palavras. Já em vocalização, aspecto que se quer destacar, foi registrado uma variabilidade grande de desempenho, porém com duas características distintas: na presença da figura, a vocalização exibia mais distorções do que na presença da palavra impressa, quando a vocalização era emitida com maior correspondência ponto a ponto. Nesse padrão de desempenho foi observado o mesmo número de exposições aos blocos de ensino das relações condicionais entre palavra ditada e figura $(A B)$, sendo maior em relação ao número de exposições das relações entre palavra ditada e palavra impressa (AC). Uma hipótese explicativa para esse de- 
sempenho pode ser o controle exercido pelos diferentes estímulos nas tarefas de nomear. Nomear na presença de figuras exige um controle pela relação entre a palavra ditada e a figura, já o nomear na presença da palavra impressa exige a mesma relação de controle, porém se a palavra impressa é a correspondência gráfica da palavra ditada e cada grafema corresponde a um som, então a vocalização conta com um controle visual que especifica cada parte da vocalização a ser emitida.

Considerando os resultados obtidos por Golfeto (idem) e a recomendação feita por Greer \& Ross (2008) de que a sondagem do comportamento de nomear deve ser feita como um componente do ouvir, questiona-se quais as relações existentes entre a aprendizagem do repertório receptivo, o ouvir, e o repertório expressivo, o falar, em deficientes auditivos implantados. O desempenho de falar sob controle da palavra impressa (ler) favoreceria de alguma forma melhoras no desempenho de falar sob controle de figuras ou eventos do meio (nomear), funcionando como um apoio ou pista visual?

Se emitir o desempenho vocal controlado por unidades menores que compõem a palavra impressa for condição necessária para o falar com maior precisão (e menos distorções, omissões ou trocas fonológicas) em deficientes auditivos implantados cocleares, então o ensino da relação entre palavra ditada e palavra impressa e o ensino silábico seriam condições necessárias para a emergência desse desempenho. Como o objetivo de sondar essas questões, três estudos estão em andamento (Anastácio-Pessan, 2009; Catunda, 2010; Terra, 2010). ${ }^{9}$ De maneira geral, os estudos, em conjunto, têm como objetivo verificar se pistas visuais, mais especificamente palavras impressas, fornecidas na aprendizagem receptiva, estariam relacionadas com a aquisição da nomeação de figuras. E como há evidências na literatura de que o ensino silábico (Reis, 2009) ou mesmo de composição de palavras (Hanna et al., 2004) pode melhorar a leitu-

9 Os três estudos são parte de um projeto de pesquisa que busca identificar se existem e quais são as relações estabelecidas entre o ouvir e o falar (Auxílio Pesquisa, Fapesp, Processo n ${ }^{\circ}$ 2009/51798-7). 
ra, pretende-se verificar se o ensino da seleção de sílabas teria algum efeito sobre a precisão do nomear figuras.

Os estudos de Anastácio-Pessan (2009), Terra (2010) e Catunda (2010) têm em comum o uso do microcomputador e do software $\operatorname{MST}^{\circledR}$ (Dube, 1989) para a programação das rotinas de ensino e teste e registro das respostas do participante. As sessões são gravadas em fitas VHS, para registro e análise das vocalizações. O delineamento consiste no ensino da tarefa pelo procedimento de emparelhamento com o modelo (pré-treino) e, em seguida, em uma avaliação do repertório do participante em tarefas de seleção (de figuras, se palavras, e de sílabas). As tarefas de seleção ocorrem sob controle condicional de palavras ditadas, de palavras escritas, de figuras e de movimentos orofaciais. Também serão avaliados em vocalização (leitura de palavras e nomeação de figuras) e de composição (ditado e cópia). A partir dos pré-testes, são selecionadas três palavras para compor as rotinas de ensino e de teste. Durante todo o delineamento, está prevista a condução de pós-testes de nomeação dessas palavras e figuras.

A diferença entre os três estudos está no delineamento adotado, pois se pretende verificar se há efeito da sequência de ensino de relações receptivas (seleção de palavras, seleção de figuras e de sílabas) sobre o repertório expressivo.

O delineamento de Anastácio-Pessan (2009) consiste na seguinte sequência: ensino de relações de seleção de figuras sob controle condicional da palavra ditada (ensino de relações condicionais auditivo-visuais $\mathrm{AB}$ ); posteriormente é realizado um pós-teste de nomeação de figuras (BD) e de leitura de palavras (CD); a seguir, o participante é exposto ao ensino de relações entre palavra ditada e palavra impressa (AC), seguido, novamente, pelos pós-testes de nomeação de figuras (BD) e de leitura de palavras (CD); após o segundo pós-teste de nomeação, é verificada a formação de classes pela emergência das relações $\mathrm{BC}$ e CB, seguido pelos mesmos pós-testes de nomeação de figuras (BD) e de leitura de palavras (CD); finalmente, é realizado o ensino da seleção de sílabas (AsCs), seguido pelos pós-testes de vocalização. 
Os delineamentos adotados por Terra (2010) e por Catunda (2010) consistem na manipulação dessa sequência de duas formas: no primeiro caso, o ensino é iniciado pela relação entre palavra ditada e palavra impressa (AC), seguido pelo ensino da relação entre palavra ditada e figura $(\mathrm{AB})$, testes de formação de classes $(\mathrm{BC}$ e $\mathrm{CB}$ ) e ensino da seleção de sílabas (AsCs), todos intercalados por pós-testes de nomeação (idem, ibidem); e no segundo caso, o ensino é iniciado pela relação entre palavra ditada e palavra impressa (AC), seguido pelo ensino da seleção de sílabas (AsCs), relação entre palavra ditada e figura (AB) e testes de formação de classes (BC e CB) também intercalados por pós-testes de nomeação (Terra, 2010).

Esses estudos encontram-se em andamento e têm como participantes crianças de cinco a 13 anos. A Tabela 1 exibe as principais variáveis controladas nos estudos de Anastácio-Pessan (2010) e Catunda (2010), assim como os resultados gerais obtidos nos póstestes de vocalização conduzidos após cada etapa.

Embora esses estudos ainda estejam em andamento, os dados ilustrativos do desempenho dos participantes, exibidos na Tabela 1 , evidenciam uma melhora progressiva na qualidade da realização de tarefas de vocalização da primeira até a última sondagem do pósteste de nomeação. Uma hipótese explicativa para esse aumento na porcentagem de acertos poderia ser em função das exposições sucessivas aos blocos de ensino seguidos de testes de nomeação, mais do que pela inserção da variável palavra ou sílaba impressa, se forem considerados os estudos de Anastácio-Pessan (2010) e de Catunda (2010). Isso porque a melhora no desempenho de nomear é observada, gradualmente, ao longo das etapas de ensino e não há um aumento na porcentagem de acertos após a aprendizagem de uma relação condicional em particular. Os resultados do delineamento conduzido por Mares (2009), em um estudo em andamento, aliados aos demais resultados com um maior número de participantes nesses delineamentos, poderão revelar os efeitos sobre a nomeação após o ensino de deleção de palavras impressas e de sílabas.

Ainda considerando a melhora no comportamento de nomear figuras, outra pergunta pertinente é se a imitação vocal seria condi- 


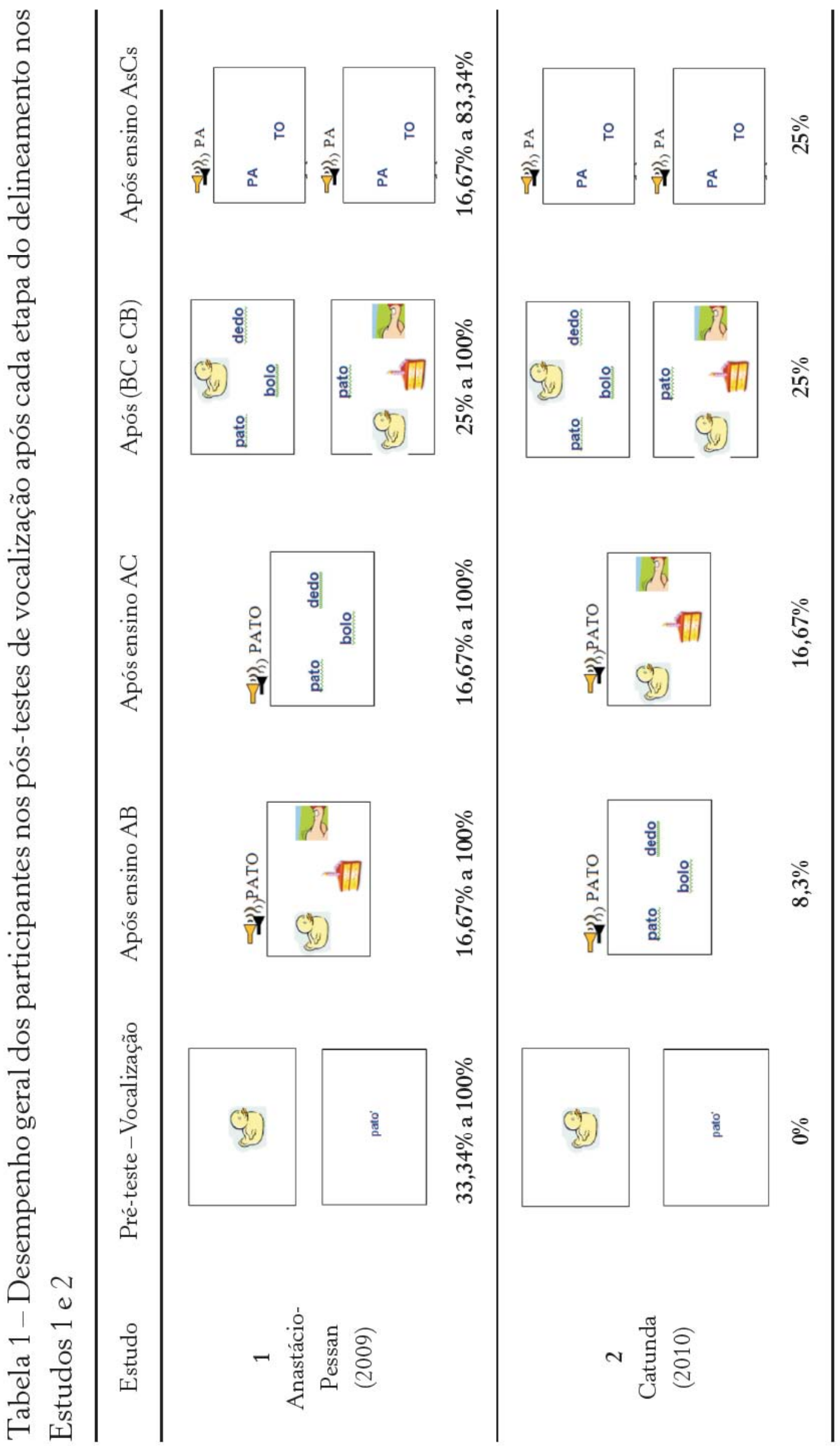


ção suficiente para que a nomeação ocorresse em implantados cocleares pré-linguais. Estudos mais sistemáticos sobre essa condição e que são conduzidos por esse grupo serão descritos a seguir.

(b) Modelagem da resposta vocal pela imitação de palavras.

Ao se considerar as condições de estabelecimento da fala inteligível, não há como se negar o papel da emissão de respostas sucessivas do vocalizar para que estas sejam, gradativamente, emitidas com a topografia mais próxima das convenções estabelecidas pela comunidade verbal de que o indivíduo participa. Considerando a topografia vocal como alvo de intervenção, há estudos que têm como objetivo verificar se a imitação de palavras seria condição para que o repertório em nomeação após o ensino de seleção de figuras ocorresse com maior correspondência pontual.

O ensino da imitação de palavras poderia se constituir em uma condição importante para a emergência da nomeação se três relações fossem estabelecidas: (1) se uma resposta vocal é colocada sob controle da palavra ditada (categoria de comportamento verbal definida como ecoico); (2) se a seleção de uma figura ocorresse sob controle condicional da palavra ditada correspondente; e se (3) a vocalização com correspondência pontual à palavra ditada fosse emitida, agora, na presença da figura.

Eikeseth \& Nesset (2003) investigaram a eficácia do ensino de imitação vocal em crianças com distúrbios fonoaudiológicos (forma inadequada de produzir e usar os sons, ou ainda, omitir sons das palavras. Por exemplo, dizer faca em vez de vaca e dizer peda em vez de pedra). Os resultados mostraram que o treino de ecoico melhorou a articulação em todos os participantes e essa melhora se manteve após seis meses. No entanto, é importante observar que essa população tinha dificuldades na linguagem expressiva, e não que não possuía nenhum tipo de distúrbio em relação à audição.

Considerando os baixo desempenho em nomeação obtido em estudos anteriores (Almeida-Verdu et al., 2008a; Battaglini, 2010; Gaia, 2005), um estudo preliminar explorou se o comportamento ecoico afetaria de forma positiva o desempenho de nomeação de fi- 
guras após o ensino de relações auditivo-visuais (Almeida-Verdu et al., 2008b).

Almeida-Verdu et al. (idem) ensinaram o comportamento ecoico para crianças pré-linguais em duas condições: 1) durante o estabelecimento de discriminações condicionais e 2) antes do estabelecimento de discriminações condicionais. Após o ensino do ecoico, os participantes receberam o ensino de relações auditivo-visuais e foram avaliados em formação de classes e nomeação de figuras. Foram demonstrados resultados positivos em todas as etapas de ensino e teste e, no caso particular de nomeação de figuras, demonstrou-se que após o ensino sistematizado de imitação vocal, independente da condição, o desempenho em testes de nomeação melhorou consideravelmente. $\mathrm{O}$ ensino do comportamento ecoico antes ou durante as relações auditivo-visuais foi condição relevante para que a nomeação de figuras com correspondência ponto a ponto com as convenções estabelecidas pela comunidade verbal fosse obtida.

Com o objetivo de explorar o papel do comportamento ecoico de forma mais sistemática, Souza (2010) fez um delineamento que consistiu de (1) um pré-treino com a finalidade de ensinar a tarefa de emparelhamento de acordo com o modelo; (2) um pré-teste que avaliou o repertório de entrada em reconhecimento auditivo, nomeação e ecoico e selecionou três palavras com baixa porcentagem de acertos que foram utilizadas no ensino; (3) o ensino de seleção de uma figura dentre três possíveis sob controle condicional da palavra ditada pelo procedimento de fading out $;^{10}$ (4) um primeiro pós-teste de nomeação; (5) o ensino sistematizado de imitação vocal, que inicialmente apresentava a palavra ditada pelo autofalante, e no caso de vocalizações sem correspondência pontual, a palavra era ditada novamente e na tela do computador eram exibidos os movimentos orofaciais correspondentes à palavra; e, por fim, (6) o segundo pós-

10 O procedimento de fading out consistia, inicialmente, em relações de identidade visual entre figuras, seguidas da sobreposição de um estímulo auditivo ao modelo visual e esmaecimento do modelo visual, até que tornava a tentativa puramente auditivo-visual. 
teste de nomeação. As principais condições experimentais e os principais resultados são apresentados na Tabela 2.

$\mathrm{Na}$ avaliação do repertório de entrada, todos os participantes obtiveram melhor desempenho nos repertórios receptivos (mais de $85 \%$ de acertos) em relação aos expressivos (valores variaram entre $20 \%$ e $80 \%$ ). Todos os participantes tiveram desempenho preciso no ensino de relações condicionais auditivo-visuais. Quatro participantes apresentaram a nomeação de figuras com maior correspondência pontual após o segundo pós-teste de nomeação em relação ao primeiro. Durante o ensino de ecoico, três crianças mantiveram o desempenho de $100 \%$ de acertos após a retirada das pistas orofaciais. Apenas uma participante não precisou das pistas (os dados dessa participante não são apresentados na Tabela 2). Embora todas as topografias vocais exigidas nos pós-testes de nomeação constituíssem o repertório vocal dos participantes e estivessem presentes no pré-teste, o ensino não garantiu condições suficientes para que todas fossem emitidas na presença das figuras que compuseram o ensino. Contudo, é possível afirmar que repertórios verbais expressivos necessitam de condições de ensino específicas em implantados cocleares e que o ensino de ecoico pode ser uma condição importante para a melhora do desempenho.

Esses resultados evidenciam que, embora o ensino da imitação de palavras possa se constituir condição necessária para topografias vocais mais precisas, parece não constituir condição suficiente. Além disso, o apoio em pistas orofaciais parece ser condição transitória importante para alguns participantes, fornecendo pistas suplementares para a emissão de topografias vocais.

Esses dados são condizentes com dados clínicos da Fonoaudiologia, em que o terapeuta verifica a estimulabilidade de cada som que o sujeito não foi capaz de emitir corretamente durante a avaliação fonológica. Esse é um procedimento clínico para determinar se a criança é hábil em revisar o erro na fala quando são dadas pistas facilitadoras (Powell et al., 1996). Isso é necessário para conhecer a habilidade que o indivíduo possui em modificar imediatamente os erros na produção da fala quando apresentado um modelo 
152 TÂNIA GRACY MARTINS DO VALLE E ANA CLÁUDIA BORTOLOZZI MAIA (ORGS.)

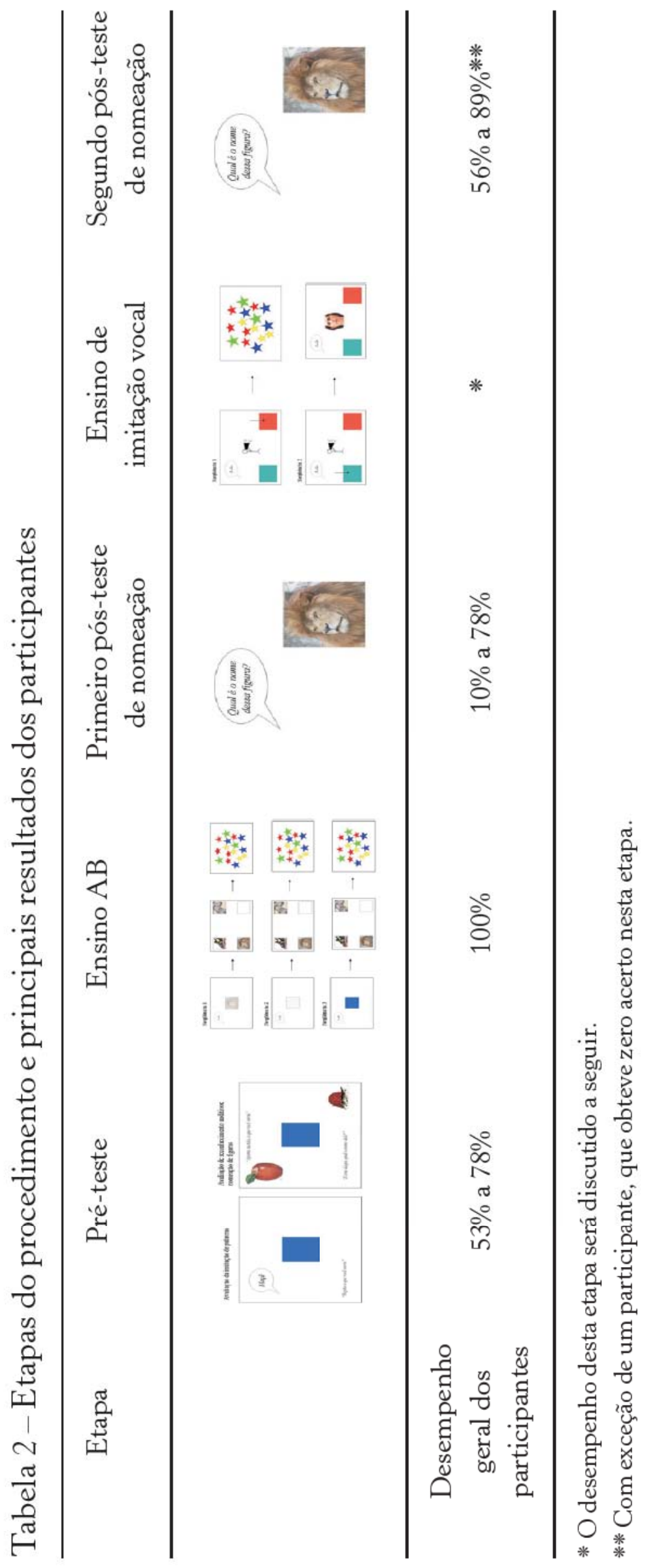


articulatório desse som. Se o desempenho da criança for melhor na tarefa imitativa do que na emissão espontânea, ela é considerada estimulável para esse som (Tyler, 1996).

\section{Conclusão}

Ainda que se considerem as várias evidências empíricas na literatura sobre a independência funcional entre operantes verbais, no caso desse conjunto de trabalhos as relações entre o ouvir e o falar ainda precisam ser esclarecidas, assim como as condições de ensino que promovam desempenho vocal mais preciso.

Considerando as relações que o ouvir pode estabelecer com o falar, ou, mais especificamente, do falar como componente do ouvir, outra hipótese plausível é a de que eles se relacionem de forma cíclica, assim como o ler e o escrever, tal como proposto por Lee \& Sandersen (1987). Para Lee \& Sandersen (1987) a composição/soletração de palavras pode ser um subproduto da escrita. Assim, descrevem que o ler e o escrever estabelecem um ciclo na medida em que aquilo que um indivíduo escreve na sala de aula tem efeito sobre ele mesmo, sobre seu professor e sobre outros alunos, da mesma forma que o que ele lê produz efeitos de mesma magnitude. Lee \& Pleger (1982) usaram o ciclo leitura-escrita para obter a composição de palavras. Os participantes liam uma lista de dez palavras isoladas sucessivamente e depois eram solicitados a escrever cada uma. Esse ciclo de leitura-escrita com as palavras foi repetido até que os participantes compusessem corretamente. Lee \& Pegler (idem) observaram desempenhos em que os participantes escreviam, nas sucessivas tentativas de composição, formas não padronizadas de palavras, mas que se assemelhavam à palavra apresentada como modelo na leitura (por exemplo: a criança escrevia uma série de levf, levi, levic, leva antes de passar a escrever leave.

A análise dos desempenhos nos sucessivos testes de nomeação conduzidos nesses estudos tem revelado um padrão de desempenho semelhante ao observado por Lee \& Pegler (idem) na escrita. Os 
participantes tendem a emitir topografias vocais incoerentes com as estabelecidas pela comunidade verbal. Ao longo de sucessivos testes, o desempenho passa a assemelhar-se cada vez mais às convenções da comunidade verbal e, em alguns casos, chegam perto da precisão. Se esses participantes necessitariam de mais exposições ao ciclo ouvir e falar é um aspecto a ser explorado em estudos subsequentes.

Finalizando, esses estudos tomam crianças com deficiência auditiva pré-lingual implantadas como uma amostra valiosa para o estudo das origens da aprendizagem relacional envolvendo estímulos auditivos. A pouca experiência auditiva, aliada à tecnologia biomédica, constitui ótima condição para o estudo sobre como estímulos sonoros adquirem funções simbólicas e como o falar se relaciona com o ouvir.

\section{Referências bibliográficas}

ALMEIDA-VERDU, A. C. M. et al. Relational learning in children with deafness and cochlear implants. Journal of the Experimental Analysis of Behavior, v.89, n.3, p.407-24, 2008a.

. Ouvir e falar: repertório de comunicação em surdos que receberam o implante coclear. In: PINHO, S. Z.; SAGLIETTI, J. R. C. (Orgs.). Revista Eletrônica Núcleos de Ensino. São Paulo: Unesp, p.902-13, 2008b.

ANASTÁCIO-PESSAN, F. L. A. Evolução da nomeação após a aquisição de relações auditivo-visuais envolvendo figuras, palavras escritas e sílabas em deficientes auditivos implantados. Dissertação (Mestrado, em andamento). Faculdade de Ciências, Universidade Estadual Paulista, Bauru. Capes, INCT-ECCE.

BATTAGLINI, M. P. Reconhecimento de palavras, nomeação de figuras e de palavras impressas em surdos implantados pré-linguais. Dissertação (Mestrado). Faculdade de Ciências, Universidade Estadual Paulista, Bauru, 2010.

BEVILACQUA, M. C. Implante coclear multicanal: uma alternativa na habilitação de crianças surdas. Tese (Livre docência). Faculdade de Odontologia, Universidade de São Paulo, Bauru, 1998. 
et al. M. Implante coclear: audição e linguagem em crianças deficientes auditivas pré-linguais. Pró-Fono Revista de Atualização Científica, Barueri, v.19, n.3, 2007.

BOOTHROYD, A. Auditory perception of speech contrasts by subjects with sensorineural hearing loss. Journal of Speech and Hearing Research, v.27, n.1, p.134-44, 1984.

BRINO, A. L. F.; DE SOUZA, C. B. A. Comportamento verbal: uma análise da abordagem skinneriana e das extensões explicativas de Stemmer, Hayes e Sidman. Interação em Psicologia, v. 9, n.2, p.25160, 2005.

CATUNDA, L. K. Q. Efeito da ordem de ensino sobre a nomeação em deficientes auditivos implantados cocleares após a aquisição de diferentes relações auditivo-visuais: figuras, palavras escritas e sílabas. Relatório de pesquisa (Apoio Técnico). Fapesp, Processo n ${ }^{\circ} 04742$ 3/2010.

CUVO, A. J.; RIVA, M. T. Generalization and transfer between comprehension and production: a comparison of retarded and nonretarded persons. Journal of Applied Behavior Analysis, v.13, n.2, p.315-31, 1980.

DA SILVA, W. R. et al. Relational learning in deaf children with cochlear implants. Experimental Analysis of Human Behavior Bulletin, v.23, n.24, p.1-8, 2006.

EIKESETH, S.; NESSET, R. Behavioral treatment of children with phonological disorder: The efficacy of vocal imitation and sufficientresponse-exemplar training. Journal of Applied Behavior Analysis, v.36, p.325-37, 2003.

GAIA, T. F. Avaliação do repertório verbal inicial em crianças com deficiência auditiva pré-lingual usuárias de implante coclear. Dissertação (Mestrado em Educação Especial). Universidade Federal de São Carlos, São Carlos, 2005.

GALVÃO, O. F.; BARROS, R. S. Passo 12: o comportamento verbal. In: _ _ Curso de introdução à análise experimental do comportamento. Belém: Universidade Federal do Pará, 2001, p.53-8. GOLDFELD, M. A criança surda: linguagem e cognição numa perspectiva sociointeracionista. São Paulo: Plexus, 2002.

GOLFETO, R. M. Compreensão e produção de fala em crianças com surdez pré-lingual usuárias de implante coclear. Dissertação (Doutorado). Universidade Federal de São Carlos, São Carlos, 2010. 
GUESS, D. A functional analysis of receptive language and productive speech: acquisition of the plural morpheme. Journal of Applied Behavior Analysis, v.2, n.1, p.55-64, 1969.

HANNA, E. S. et al. Effects of delayed constructed-response identity matching on spelling of dictated words. Journal of Applied Behavior Analysis, v.37, n.2, p.223-27, 2004.

McMORROW, M. J. et al. Cues-pause-point language training: teaching echolalics functional use of their verbal labeling repertoires. Journal of Applied Behavior Analysis, v.20, n.1, p.11-22, 1987.

MORET, A. L. M. et al. Avaliação da produção de fala em crianças deficientes auditivas usuárias de implante coclear multicanal. Revista Sociedade Brasileira de Fonoaudiologia, v.13(1), p.45-51, 2008.

PASSOS, M. L. R. F. A análise funcional do comportamento verbal em Verbal behavior (1957), de B. F. Skinner, Revista Brasileira de terapia comportamental e cognitiva, n.2, p.195-213, jul.-dez. 2003.

POWELL, T. W. et al. Stimulability: a useful clinical tool. J. Commun Disord, v.29, n.4, p.237-53, 1996.

REIS, T. S. Avaliação da eficácia de um programa suplementar para o ensino de leitura e escrita aplicado em ambiente escolar. Dissertação (Mestrado em Educação Especial). Universidade Federal de São Carlos, São Carlos, 2008.

ROBBINS, A. M. Rehabilitation after cochlear implantation. In: NIPARKO, J. K. et al. Cochlear implants: principles and practices. Philadelphia: Lippincott Williams \& Wilkins, 2000, p.323-67.

SIDMAN, M.; TAILBY,W. Conditional discriminations vs. matchingto-sample: an expansion of the testing paradigm. Journal of the Experimental Analysis of Behavior, v.37, n.1, p.5-22, 1982.

SKINNER, B. F. O comportamento verbal. São Paulo: Cultrix, 1978.

SOUZA, F. C. Efeito do ensino de ecoico sobre a nomeação de figuras em deficientes auditivos pré-linguais que receberam o implante coclear. Relatório de pesquisa (iniciação científica). Fapesp, Processo $n^{\circ}$ 2008/57994-0, 2010.

TERRA, B. M. Efeito da ordem de ensino sobre a nomeação em deficientes auditivos implantados cocleares após a aquisição de diferentes relações auditivo-visuais: palavras escritas, sílabas e figuras. Relatório de pesquisa (iniciação científica). CNPQ Processo n ${ }^{\circ} 1048872009$ 5, 2010 . 
TYLER, A. A. Assessing stimulability in toddlers. J. Commun. Disord., v.29, n.4, p.279-97, 1996.

WERTZNER, H. F. et al. Análise acústica e índice de estimulabilidade nos sons líquidos do português brasileiro. Revista Cefac, v.9, n.3, p.339-50, 2007. 



\section{8 \\ ESTRATÉGIAS METODOLÓGICAS NO ESTUDO DA ATUAÇÃO PROFISSIONAL DO TREINADOR ESPORTIVO}

Jair Lopes Junior e Cintia Allyson Jensen ${ }^{1}$

\section{Introdução}

No cenário esportivo, o treinador apresenta-se como o profissional diretamente responsável, em última instância, pelas funções de aprimorar e de melhor qualificar o desempenho dos atletas. A literatura advoga que o exercício adequado de tais funções depende da existência de um conjunto diversificado de condições (Antonelli \& Salvini, 1978; Becker Jr., 2000; Martens et al., 1989).

O presente capítulo, fundamentado na Análise do Comportamento enquanto orientação teórica (Abreu-Rodrigues \& Ribeiro, 2005; Baum, 1999; Tourinho \& Luna, 2010), concentra ênfase nas condições definidas pelos repertórios de instrução, ou seja, admite-se que significativa parcela da atuação profissional do treinador esportivo envolve a aquisição e o desenvolvimento de operantes verbais que exercem a função de, enquanto estímulos verbais antecedentes à resposta, descrever e especificar possíveis relações de contingência entre eventos (Catania, 1999; Cerutti, 1989; Okouchi, 1999; Skinner,

1 Programa de Pós-Graduação em Psicologia do Desenvolvimento e Aprendizagem da Unesp - Bauru. 
1974). O objetivo deste texto consiste, de modo genérico, em expor e discutir aspectos metodológicos que poderiam, enquanto subsídio para programas de pesquisa e de intervenção, ampliar a compreensão de características dos repertórios comportamentais de instruir emitidos pelo treinador esportivo em situação de competição.

O capítulo apresenta, inicialmente, uma sucinta caracterização conceitual da acepção de comportamento de instruir que orientou a execução da pesquisa relatada. Em seguida, expõe os aspectos metodológicos que determinaram os procedimentos de coleta, de tabulação e de análise dos dados obtidos. O capítulo foi finalizado com discussões que procuraram relacionar os principais resultados com conhecimentos pertinentes da Análise do Comportamento, bem como da Psicologia do Esporte, com ênfase em possíveis contribuições e questões de pesquisa derivadas das evidências ora produzidas que justificariam a continuidade de programas de investigação sobre processos de ensino e de aprendizagem vinculados ao comportamento de instruir do treinador esportivo.

\section{O comportamento de instruir como condição para o exercício profissional do treinador esportivo}

Em termos genéricos, a literatura que demarca contribuições da Psicologia para a área do esporte acusa dois consensos salientes (Cillo, 2002; 2000; Martin, 2001; Martin \& Tkachuk, 2001). De início, destaca-se que tais contribuições concentram-se na investigação de processos de comunicação entre o treinador e seus atletas (Becker Jr., 2000; Martens \& Cols., 1989; Martin, 2001). Além disso, cabe reconhecer que a investigação de tais processos de comunicação exibe uma diversidade de orientações teóricas, acarretando em variabilidade de terminologia, bem como em pluralidade metodológica nas estratégias de investigação.

No âmbito do presente capítulo, em consonância com a fundamentação teórica da Análise do Comportamento, os denominados processos de comunicação (Baum, 1999; Pereira, 2000; 
Skinner, 1957) foram investigados, com ênfase no comportamento verbal de instruir do treinador esportivo emitido em situações de competição.

O comportamento verbal pode ser observado na interação falante-ouvinte. Trata-se de um comportamento operante no qual é fundamental a presença do ouvinte como elemento com funções de fornecer ou mediar consequências para o comportamento do falante. Para a instalação do comportamento verbal é necessária a presença do ouvinte. Posteriormente, é suficiente a presença do falante para caracterizar efeitos de uma história prévia da relação falante-ouvinte (Catania, 1999; Peterson, 1978; Skinner, 1957).

Em termos conceituais, a Análise do Comportamento sustenta que o comportamento verbal gera consequências, sendo que o significado desse comportamento está nas funções que ele exerce, nas consequências produzidas dentro de um contexto, ou seja, em uma história de reforço. No contexto esportivo, por exemplo, os atletas que ouvem e reforçam propriedades do comportamento verbal do treinador são chamados de membros da comunidade verbal deste (Baum, 1999; Skinner, 1957). Os atletas, ou, mais precisamente, as ações dos atletas, são elementos imprescindíveis para a aquisição, a manutenção e o desenvolvimento de propriedades do repertório verbal do treinador, neste caso, o falante.

Reiterando argumentos já expostos com praticamente uma década de antecedência (Skinner, 1957), Skinner (1966/1984)2 diferenciou e demarcou as instruções como estímulos verbais descritivos de contingências cujas consequências não resultam de ações diretas do falante (instrutor), bem como reconheceu a manifestação incompleta ou fragmentada de tais operantes verbais.

Em termos das definições adotadas no âmbito deste capítulo, cumpre mencionar, em consonância com a literatura ora especificada (Catania, 1999; Cerutti, 1989; Skinner, 1966/1984; 1974), que re-

2 Neste formato de apresentação da referência bibliográfica, a primeira e a segunda datas informam, respectivamente, o ano de publicação original e o ano da edição consultada. 
gras serão consideradas estímulos verbais que resultam de práticas reforçadoras e/ou punitivas de comunidades verbais. Enquanto estímulo verbal, as regras especificam ou descrevem, com graus variados de precisão, de modo completo ou fragmentado, relações de dependência ou relações contingentes entre, ao menos, dois eventos ou duas classes de eventos. As regras serão consideradas instruções sob três condições mutuamente complementares:

a) quando as relações especificadas fizerem referência a domínios específicos, ou seja, as relações de controle previstas estiverem restritas a contextos específicos ou as relações mencionarem restrições situacionais;

b) quando as consequências previstas pela emissão ou não emissão dos repertórios descritos não são arranjadas pelo falante;

c) quando as relações especificam ou implicam respostas ou classes de respostas de, ao menos, um ouvinte.

Admitindo-se que parte significativa da atuação profissional do treinador esportivo define-se pelo fornecimento de instruções aos seus atletas, no âmbito do fortalecimento e da expansão das contribuições da Psicologia para a área do esporte na investigação de processos de comunicação, parece-nos pertinente indagar se as características acima assinaladas na demarcação conceitual das instruções seriam observadas na atuação do treinador sob condições de competição.

Estudos anteriores da literatura comprometidos com a investigação de características do comportamento de instruir priorizaram duas dimensões de tal repertório, a saber, as variáveis relacionadas com a audiência e aquelas relacionadas com propriedades topográficas do comportamento de instruir (Lemos, 2004; 2005; Macedo, 2002; Schmidt, 1999). Em outros termos, a literatura registra convergência de estudos que exploraram possíveis relações entre tipos de audiência e de topografia para repertórios instrucionais. Estimase que ampliações em tais caracterizações poderiam constituir conhecimentos relevantes para subsidiar intervenções em áreas aplicadas, tanto quanto propostas de programas de formação inicial ou em serviço de diferentes carreiras profissionais. 
Com o propósito de caracterizar os repertórios instrucionais emitidos por uma professora do Ensino Fundamental no manejo de contingências em sala de aula, Schmidt (1999) filmou uma sequência consecutiva de aulas, com posterior edição de episódios. A autora constatou, em termos da audiência priorizada, um aumento no número de instruções gerais, a saber, para o grupo de alunos, com o consequente decréscimo de instruções individuais. Quanto à topografia das instruções, prevaleceram as instruções orais, dentre todas as instruções iniciais fornecidas pela professora. Outras topografias foram registradas, como instruções visuais, com demonstrações, mas sempre associadas com respostas orais.

Em termos metodológicos, o estudo de Schmidt (idem) evidenciou a obtenção de gravações, em sequências, em vídeo de uma sucessão de aulas, com um número limitado de sujeitos (a professora e um grupo de alunos) e sob condições nas quais era possível o registro do comportamento dos alunos em relação às instruções de modo relativamente imediato e intermediando a obtenção dos registros entre aulas sucessivas.

Nos últimos anos, investigações que priorizaram a caracterização de repertórios instrucionais foram registradas também no âmbito do esporte e, mais precisamente, envolvendo situações de interação entre o treinador e seus atletas.

Macedo (2002) e Lemos (2004) destacaram a importância do estudo de comportamentos verbais emitidos pelo treinador, entre os quais alguns que cumpriam funções instrucionais em situações de jogo para a compreensão de processos de ensino e de aprendizagem de repertórios relevantes pelos atletas de algumas modalidades esportivas.

Lemos (2005) investigou tais comentários a partir das interações verbais mantidas pelo treinador e os jogadores das categorias de base (infantil e juvenil) de equipes de handebol, considerando as situações de ataque e de defesa que ocorrem durante os treinos. A coleta de dados foi efetuada em uma quadra de handebol durante os treinos. Foram observados quatro treinos de dois treinadores. Os registros foram efetuados oralmente pela pesquisadora, que repetiu ao 
gravador cada verbalização feita pelos treinadores durante os treinos. Esses dados foram transcritos para uma folha de registros construída pela pesquisadora. Nessa folha, nas linhas foram colocados: a quem se dirigia o comentário; o momento do comentário (antes, durante ou após a ação do jogador); e comentários sobre o desempenho do jogador.

Como principais resultados obtidos com os dois treinadores, caberia destacar: a) maior frequência de comentários na situação de ataque do que de defesa; b) os elogios foram mais frequentes na situação de ataque; c) os comentários corretivos que descreviam os desempenhos esperados (previstos) foram emitidos com maior frequência nas situações de ataque, enquanto que os comentários que apontavam desempenhos distintos dos previstos (incorretos) foram emitidos com maior frequência nas situações de defesa; d) predominaram comentários direcionados, em termos de audiência, para o indivíduo, sendo que, vale destacar, quando os comentários informavam desaprovação, a maior frequência foi direcionada ao grupo de jogadores.

Verifica-se, assim, que investigações sobre audiência e topografia de repertórios instrucionais do treinador esportivo efetuaram adequações de características metodológicas de estudos sobre tais repertórios realizados em contexto escolar. Cabe destacar a manutenção de registros sequenciais sucessivos de interações envolvendo um mesmo grupo de participantes. A exemplo do estudo de Schmidt (1999) com aulas sucessivas, Lemos (2005) obteve registros de interações em jogos sucessivos. Contudo, os estudos que envolveram o comportamento verbal do treinador esportivo evidenciaram restrições na caracterização de propriedades topográficas e, em decorrência, limitações na exploração de possíveis vínculos entre audiência e topografia.

Destarte, no presente capítulo, a pesquisa apresentada investigou propriedades de audiência e de topografia do repertório instrucional do treinador esportivo também de modo sequencial, contudo, envolvendo a repetição de condições de interação distintas e não a repetição de uma mesma condição. De modo mais específi- 
co, a pesquisa relatada a seguir fundamentou-se em investigar, mediante registro em vídeo, características de audiência e de topografia de repertórios instrucionais em três situações distintas e consecutivas que definem a rotina de trabalho profissional do treinador esportivo, a saber, em treinos que antecedem e que são posteriores aos jogos, bem como interações nos dias dos três jogos sucessivos de uma mesma equipe.

Assim, de modo mais específico, o objetivo da pesquisa relatada a seguir consistiu em verificar se a adoção de tal estratégia metodológica de coleta de dados permitiria expandir o alcance das caracterizações de repertórios instrucionais do treinador esportivo em termos da possível identificação de consistências e de estabilidades em parcela relevante do que define sua atuação profissional.

\section{Método}

\section{Participantes}

A pesquisa foi realizada com a equipe de futebol juniores de um clube do interior do estado de São Paulo. O treinador participante tem formação acadêmica em Educação Física, foi jogador profissional de futebol e atua como treinador desde 1984. Participaram também 25 atletas. A autorização para a execução da pesquisa foi obtida junto à diretoria do Departamento de Futebol Amador do clube e efetivada mediante as assinaturas do termo de consentimento livree informado. O projeto foi aprovado pelo Comitê de Ética em Pesquisa da Faculdade de Ciências da Unesp - Bauru (Processo n ${ }^{\circ} 2349$ / 46/01/07).

\section{Material}

Na execução dos procedimentos de coleta e de tabulação dos registros foi utilizada uma filmadora digital modelo Hand Cam/DCRDVD 108, computador com gravador de DVD e placas de captura 
de imagens, além de aplicativos para o armazenamento e a edição dos registros em vídeo.

\section{Procedimento de coletas de dados}

A pesquisa foi realizada durante a fase de classificação de uma competição oficial nacional. As atividades de registro das verbalizações do treinador esportivo foram efetuadas no estádio durante os treinos de campo que antecederam e que foram realizados imediatamente após cada jogo realizado, bem como no salão de conferências do hotel no qual ocorreram as preleções no período da manhã dos dias de cada um dos três jogos disputados no período vespertino.

Etapa 1/Período de ambientação - Precedendo ao início da coleta de dados, a pesquisadora efetuou um período de ambientação de aproximadamente vinte dias com a comissão técnica e os atletas. Nesse período, inicialmente a pesquisadora participou, como ouvinte e sem a filmadora, de duas preleções ministradas pelo treinador, no campo do centro de treinamento do clube, antes de treinamentos com bola que precederam a realização do penúltimo jogo amistoso para a competição nacional oficial. Nos dois treinos posteriores que intercalaram a penúltima e a última partida amistosa, a pesquisadora filmou as interações verbais entre o treinador e os atletas, dentro do campo, antes do início dos treinos com bola. Os atletas encontravam-se dispostos em um semicírculo no centro do campo e de frente para o treinador. A pesquisadora, com a filmadora ligada, posicionou-se ao lado do treinador e efetuou a gravação das interações verbais sem qualquer comentário. O período de ambientação foi finalizado com a filmagem da segunda partida amistosa.

Etapa 2 - Os procedimentos nessa etapa ocorreram durante a realização dos três jogos da fase de classificação. A mesma sequência de procedimentos foi adotada para cada um dos três jogos disputados consecutivamente. Para cada um dos três jogos, essa sequência compreendia: 
Fase 1- Gravação do último treino antes do jogo. O procedimento consistiu em registrar em vídeo as interações verbais entre o treinador e os atletas, dentro do campo de treinamento, na preleção que antecedeu às atividades de exercícios físicos ou com bola no último treino antes do jogo oficial. Os atletas estavam dispostos em semicírculo no centro do campo e de frente para o treinador e demais membros da comissão técnica. A pesquisadora, durante toda a preleção, permaneceu ao lado do treinador, operando a filmadora de modo a captar imagens e sons emitidos pelo treinador e pelos atletas. A gravação foi encerrada ao final da preleção. Foram efetuadas três gravações, a saber, nos últimos treinos que precederam a realização dos jogos 1,2 e 3.

Fase 2 - Gravação da preleção realizada no dia do jogo. Considerando que os três jogos da fase classificatória foram programados para o período vespertino no estádio municipal, os jogadores receberam as últimas instruções para cada jogo no período da manhã do dia do jogo na sala de conferências do hotel. Colocado à frente da sala, o treinador fixou em mesas, de modo vertical, um campo de futebol imantado de aproximadamente 1,2 metro de altura e sessenta centímetros de largura com peças (imãs) coloridas circulares, com um centímetro de diâmetro, numeradas na parte superior. Essas peças simulavam os jogadores da própria equipe e da adversária. Nas três preleções efetuadas nessa sala, no período da manhã dos jogos 1,2 e 3 , o treinador permaneceu em frente aos atletas, na posição de palestrante, com o campo imantado disposto verticalmente sobre duas mesas ao seu lado. Os atletas permaneceram sentados nas poltronas, dispostas em fileiras de um auditório. Nessa mesma sala, a pesquisadora ocupou posição designada pelo treinador, a saber, à frente, na lateral do treinador, de modo a captar, com a filmadora, imagens e sons das interações verbais efetuadas entre ele e os atletas. A gravação foi encerrada ao final da preleção. Foram realizadas três gravações, uma em cada preleção efetuada no período da manhã dos jogos 1,2 e 3 .

Fase 3 - Gravação da preleção realizada no primeiro treino após cada um dos três jogos. A última etapa de gravação para cada jogo reali- 
zado consistiu no registro em vídeo das interações verbais entre o treinador e os atletas que ocorreram no primeiro treino após a realização de cada jogo. As gravações ocorreram, a exemplo da Fase 1, dentro do campo de treino. Os jogadores permaneceram dispostos em semicírculo, no centro do campo, de frente para o treinador. Também a exemplo da Fase 1, a pesquisadora manipulou a filmadora ao lado do treinador, captando imagens e sons da interação. O tempo de gravação correspondeu à duração da preleção. $\mathrm{Na}$ Fase 3 foram realizadas três gravações, a saber, no primeiro treino após os jogos 1,2 e 3.

Assim, para cada um dos três jogos disputados ocorreu a execução dos procedimentos das Fases 1, 2 e 3 acima descritos.

\section{Procedimento de tabulação e de análise de dados}

Conforme salientado na seção anterior, ocorreram três sessões de gravação (Fases 1, 2 e 3) para cada jogo disputado, perfazendo um total de nove sessões de registros. Imediatamente após o final dos registros em vídeo das três fases de cada jogo, ocorreu a transcrição do áudio das gravações efetuadas, com ênfase na identificação das instruções verbais fornecidas pelo treinador. Finalizadas as transcrições, foram definidos critérios para a caracterização das instruções transcritas.

O primeiro critério, a saber, a audiência priorizada, replicou a escolha adotada por Schmidt (1999) e Lemos (2005). Em acordo com estes, as instruções foram caracterizadas com base no tipo de audiência priorizada, ou seja, as instruções foram caracterizadas como instruções gerais ou instruções individuais. Nas instruções gerais, a audiência consistia no grupo de atletas de modo indistinto. Diferentemente, nas instruções individuais, o treinador fez referência explícita a um atleta como destinatário da instrução fornecida.

De acordo com o segundo critério adotado, a exemplo de Schmidt (1999), as instruções gerais e individuais foram caracterizadas com base em dimensões topográficas das respostas emitidas pelo treina- 
dor. Deste modo, as instruções gerais e individuais foram caracterizadas como vocal (VO), vocal combinada com visual (VO+VI), vocal combinada com demonstração (VO+DE) ou como vocal combinada com visual e com demonstração ( $\mathrm{VO}+\mathrm{VI}+\mathrm{DE})$.

A definição de cada uma dessas subdivisões encontra-se na Tabela 1.

Tabela 1 - Tipos de instruções apresentadas pelo treinador para os atletas, caracterizadas segundo propriedades topográficas

\begin{tabular}{lcl}
\hline Tipo de instrução & Abreviação & \multicolumn{1}{c}{ Descrição } \\
\hline \multicolumn{1}{c}{ Vocal } & VO & O treinador apresenta a instrução oralmente. \\
\hline $\begin{array}{l}\text { Vocal combinada } \\
\text { com visual }\end{array}$ & VO+VI & $\begin{array}{l}\text { O treinador apresenta a instrução } \\
\text { oralmente e aponta para posições do campo } \\
\text { de futebol imantado. }\end{array}$ \\
\hline $\begin{array}{l}\text { Vocal combinada } \\
\text { com demonstração }\end{array}$ & VO+DE & $\begin{array}{l}\text { O treinador apresenta a instrução oralmente } \\
\text { e demonstra, gesticulando, como o } \\
\text { comportamento especificado pela instrução } \\
\text { deveria ser emitido. }\end{array}$ \\
\hline $\begin{array}{l}\text { Vocal combinada com } \\
\text { visual e com } \\
\text { demonstração }\end{array}$ & VO+VI+DE & $\begin{array}{l}\text { O treinador apresenta a instrução oralmente, } \\
\text { aponta para o campo de futebol imantado e } \\
\text { demonstra o desempenho requerido pela } \\
\text { instrução por meio de gestos. }\end{array}$ \\
\hline
\end{tabular}

Dois juízes efetuaram a leitura, em separado, das transcrições de todos os registros em vídeo. Inicialmente, cada juiz selecionou, na transcrição, os registros passíveis de caracterização como instrução, de acordo com os critérios conceituais mutuamente complementares explicitados na introdução. Para cada registro consensualmente designado como instrução, os juízes formalizaram oralmente uma justificativa com base na literatura consultada (Catania, 1999; Cerutti, 1989; Skinner, 1966/1984; 1974). Posteriormente, no trabalho de confrontação das caracterizações efetuadas, diante de discordância entre os juízes sobre a caracterização de uma determinada instrução, esta foi excluída. Para efeito de descrição e de análise fo- 
ram consideradas apenas as instruções sobre as quais se verificou concordância na caracterização dos dois juízes.

\section{Resultados e discussão}

As instruções emitidas pelo treinador em cada uma das três fases dos três jogos disputados foram tabuladas e analisadas com base nas audiências e nas propriedades topográficas, sendo que a Tabela 2 informa o número de instruções de acordo com tais critérios de caracterização.

Constatou-se que, para os três jogos, na Fase 1, as instruções com número mais elevado de ocorrências foram aquelas direcionadas para o grupo de atletas e prioritariamente vocais. Para os três jogos houve elevação no número de instruções fornecidas na preleção efetuada no dia do jogo (Fase 2), em comparação com o número de instruções fornecidas no último treino que precedeu ao jogo (Fase 1) e no primeiro treino após cada jogo. Na Fase 2 dos três jogos, o número de instruções individuais foi superior ao número de instruções gerais, sendo que, para as instruções individuais, as instruções vocais e visuais registraram maior ocorrência. A exemplo do último treino que precedeu cada um dos três jogos (Fase 1), no primeiro treino realizado após cada jogo (Fase 3), as ocorrências das instruções gerais e vocais superaram as ocorrências das demais modalidades.

Portanto, precedendo à realização dos jogos, diante dos atletas no campo de treinamento, o treinador emitiu instruções predominantemente vocais para o grupo, sem menção a atletas específicos e prescindindo de indicações e de sinalizações visuais de posicionamentos, bem como de demonstrações correspondentes a tais instruções. Por sua vez, diante dos atletas, no hotel, no dia do primeiro jogo, o número de instruções individuais, direcionadas para jogadores específicos, superou o número das instruções fornecidas para o grupo. Diante da impossibilidade física de utilização de um campo de futebol com as dimensões minimamente semelhantes àquelas do campo no qual ocorreria a partida, predominaram, para os atletas 


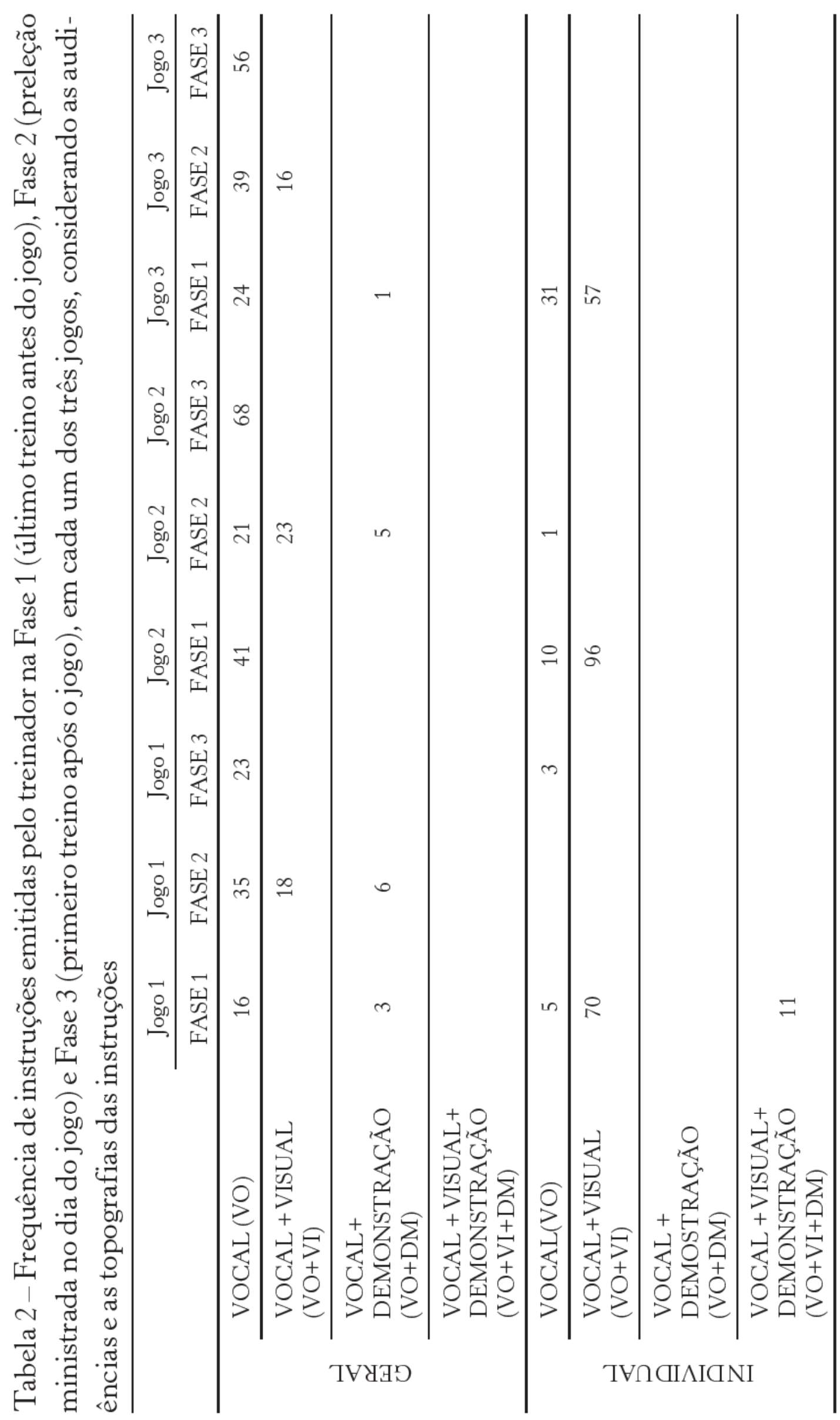


individualmente, instruções vocais com indicações visuais de posicionamentos em um campo de futebol imantado com dimensões muito reduzidas.

Portanto, a maior proximidade do jogo acusou mudanças no comportamento instrucional do treinador em termos de audiência e de topografia: as instruções foram direcionadas para atletas específicos e com ênfase em sinalizações e indicações de posicionamento no campo imantado, sendo que para os três jogos, o número de instruções no dia do jogo (Fase 2) foi, no mínimo, o dobro do número de instruções emitidas no último treino antes do jogo (Fase 1). Deste modo, no dia do jogo, na sala de conferências do hotel, ou seja, em uma condição ambiental fisicamente distinta daquela diante da qual os atletas atuariam, o treinador forneceu, com ênfase em cada atleta individualmente, instruções topograficamente definidas pela indicação dos posicionamentos daqueles no campo. A princípio, caberia indagar se tais características instrucionais que precederam ao jogo, ou seja, o aumento em demasia do número de instruções direcionadas a cada atleta, momentos antes do jogo, sob condições visuais e espaciais distintas e distantes daquelas diante das quais os desempenhos especificados pelas instruções deveriam ser emitidos, teriam se constituído em condição eficiente (ou funcionalmente relacionada) com a emissão do disposto nas instruções e/ou com a obtenção dos resultados previstos pela comissão técnica nos jogos.

Sob tais características instrucionais, a equipe obteve vitória no jogo 1 por uma diferença de um gol. Na primeira interação verbal prevista com o grupo após o jogo, que ocorreu no primeiro treino após esse jogo (Fase 3), no campo de treinamento, as instruções somente vocais foram destinadas praticamente só para o grupo. Deste modo, no primeiro contato com o grupo após o jogo, o repertório verbal do treinador prescindiu, em termos da audiência e das propriedades topográficas, do fornecimento de instruções, para cada atleta individualmente, que fossem definidas por indicações de posicionamento no espaço físico do campo real ou do campo imantado, bem como de gestos ou demonstrações sobre tais instruções ou sobre o desempenho dos atletas após o fornecimento das instruções 
predominantemente individuais, vocais e visuais no dia do jogo (Fase 2).

A equipe obteve vitória nos dois jogos subsequentes (jogos 2 e 3 ) pela mesma diferença de gols do jogo 1.

Admitindo-se como unidade de análise as três fases diante das quais os repertórios instrucionais foram considerados para cada jogo (duas fases anteriores ao jogo e uma posterior), os dados da Tabela 2 acusam a reincidência da mesma oscilação de audiência (geral, individual, geral) e das mesmas topografias (vocal, vocal + visual, vocal) predominantes nas manifestações de tal unidade.

A reincidência das características acima mencionadas para os repertórios instrucionais do treinador, considerando como critérios a audiência e as propriedades topográficas, foi registrada diante de três vitórias consecutivas pela mesma diferença de gols.

Poder-se-ia supor que a obtenção de três vitórias consecutivas se constituiu em condição ou evento crítico para a manutenção ou reincidência das características acima mencionadas para os repertórios instrucionais do treinador, considerando as audiências e as propriedades topográficas de tais repertórios. Nesses termos, os resultados finais obtidos nos jogos teriam cumprido a função de reforçar positivamente as oscilações em termos das audiências priorizadas pelas instruções fornecidas, bem como em termos das propriedades topográficas acima assinaladas.

\section{Conclusão}

Fundamentado na Análise do Comportamento, este capítulo apresentou uma pesquisa que investigou características do comportamento de instruir do treinador esportivo sob condições metodológicas. Tais condições consistiram na obtenção de registros de vídeo de interações entre treinador e atletas em três fases consecutivas e reincidentes de três jogos oficiais.

Diante dessas condições metodológicas, foi possível registrar regularidades e consistências do repertório instrucional em termos das 
audiências e das propriedades topográficas priorizadas que, por sua vez, sinalizaram expansões em termos de conhecimentos produzidos mediante a utilização dos recursos previamente registrados na literatura (Lemos, 2005; Schmidt, 1999).

Os recursos metodológicos utilizados evidenciaram, sob três condições de observação, regularidades nas audiências priorizadas pelas instruções do treinador, bem como nas topografias que definiram tais instruções.

Em suma, além da demonstração das regularidades acima descritas, cumpre destacar que as características metodológicas da pesquisa relatada neste capítulo igualmente ampliaram a visibilidade de questões que devem orientar a continuidade das investigações acerca de repertórios instrucionais do treinador esportivo.

Dentre tais questões, caberia destacar a necessidade de se verificar se sob as mesmas condições metodológicas ora relatadas, regularidades seriam igualmente registradas mediante análises de propriedades relacionais das instruções, ou seja, se as instruções emitidas pelo treinador seriam definidas por especificações da resposta, dos eventos subsequentes ou mesmo contingentes a tais respostas e do ambiente diante do qual tal relação de possível contingência ocorreria. Assim, caberia indagar: instruções com tais especificações seriam igualmente registradas nas três fases adotadas em relação a cada jogo consecutivamente ou, diferentemente, as especificações seriam alteradas, igualmente de modo regular, diante das fases consideradas?

Uma última questão refere-se à investigação sobre como a identificação de possíveis consistências e das regularidades poderiam fomentar a proposição de programas de formação profissional que priorizem o desenvolvimento de repertórios instrucionais baseados em análises de contingências e na avaliação cuidadosa da adequação das instruções para as condições ambientais disponíveis e para as características dos aprendizes ou atletas envolvidos. 


\section{Referências bibliográficas}

ABREU-RODRIGUES, J.; RIBEIRO, M. Análise do comportamento: pesquisa, teoria e aplicação. Porto Alegre: Artmed Editora, 2005.

ANTONELLI, F., SALVINI, A. Psicologia del esporte. Roma: Miñón, 1978.

BAUM, W. M. Compreender o behaviorismo. In: Ciência, comportamento e cultura. Porto Alegre: Artmed, 1999.

BECKER JR., B. Manual de Psicologia do Esporte E exercício. Porto Alegre: Novaprova Editora, 2000.

CATANIA, C. Aprendizagem: comportamento, linguagem e cognição. Porto Alegre: Artmed, 1999.

CERUTTI, D. T. Discrimination theory of rule-governed behavior. Journal of the Experimental Analysis of Behavior, v.51, p.259-76, 1989.

CILLO, E. Psicologia do esporte: conceitos aplicados a partir da Análise do Comportamento. In: TEIXEIRA, A. (Org.) Ciência do comportamento: conhecer e avançar. Santo André: Esetec Editores Associados, 2002, v.1, p.119-37.

Análise do comportamento aplicada ao esporte e à atividade física: a contribuição do behaviorismo radical. In: RUBIO, K. (Org.) Psicologia do Esporte. São Paulo: Casa do Psicólogo, 2000.

LEMOS, R. F. Ataque e defesa: análise de comentários de treinadores durante os treinos de categoria de base. Trabalho de conclusão de curso. Graduação em Psicologia. Pontifícia Universidade Católica de São Paulo - PUC, São Paulo, 2005.

Análise dos comentários de treinadores de handebol dirigidos aos atletas durante os treinos. Relatório. Faculdade de Psicologia: Pontifícia Universidade Católica de São Paulo - PUC, São Paulo, 2004.

MACEDO, R. H. Análise dos comentários de treinadores durante competição das categorias menores no futsal. Monografia. Faculdade de Educação Física: Universidade Estadual de Londrina, Paraná, 2002.

MARTIN, G. L. Regras e objetivos: estratégias importantes para influenciar comportamento. In: Consultoria em Psicologia do Esporte: orientações práticas em Análise do Comportamento. Campinas: Instituto de Análise do Comportamento, 2001, p.35-50. 
MARTIN, G. L.; TKACHUK, G. Psicologia Comportamental do Esporte. In: GULHARDI, H. J. \& cols. (Orgs.) Sobre comportamento e cognição: expondo a variabilidade. Santo André: Esetec Editores Associados, 2001, v.8 p.313-36.

MARTENS, R. et al. El treinador. Barcelona, Espanha: Hispano European, 1989.

OKOUCHI, H. Instructions as discriminative stimuli. Journal of the Experimental Analysis of Behavior, v.72, p.205-14, 1999.

PEREIRA, M. E. M. O estudo da linguagem pela Psicologia: uma aproximação entre Skinner e Bakhtin. São Paulo: Educ Editora, 2000.

PETERSON, N. An introduction to verbal behavior. In: OTAWA, N. W. Behavior associates. s. 1.: Inc, 1978.

SCHMIDT, A O ensino de alunos em escola especial: analisando como o professor ensina e propondo material para capacitação. Dissertação (Mestrado). Programa de Pós-Graduação em Educação Especial. UFSCAR, São Carlos, 1999.

SKINNER, B. F. Uma análise operante da resolução de problemas. In: PAVLOV; SKINNER, B. F. São Paulo: Abril Cultural, 1966/1984, p.273-301 (Os pensadores).

About behaviorism. Nova Iorque: Alfred A. Knopf, 1974. (1957) Verbal behavior. Nova Jersey: Prentice-Hall, 1957.

TOURINHO, E.; LUNA, S. V. Análise do Comportamento: investigações históricas, conceituais e aplicadas. São Paulo: Roca Editora, 2010. 


\section{9 \\ RECONSTRUÇÃO CONCEITUAL DO PRESTAR ATENÇÃO NA ANÁlISE dO COMPORTAMENTO ${ }^{1}$}

Bruno Angelo Strapasson e Kester Carrara ${ }^{2}$

\section{Introdução}

A "atenção", seja como uma capacidade mental, como um comportamento ou como uma condição para um comportamento, é um termo largamente utilizado tanto na linguagem coloquial quanto na científica. Na literatura psicológica, seu uso é comum e refere-se, normalmente, a algum processo cognitivo de seleção dos estímulos aos quais um organismo deve responder. A Análise do Comportamento (AC), de B. F. Skinner, é uma perspectiva psicológica que rejeita explicações cognitivas como entidades iniciadoras do comportamento e, portanto, rejeita a noção de que o "prestar atenção" possa ser entendido como uma instância mental selecionadora de estímulos. Por outro lado, Strapasson \& Dittrich (2008) indicam que Skinner atribuía grande importância ao estudo do tema, interpretando teoricamente esse fenômeno em diversos momentos de sua

1 Este texto é derivado da dissertação de mestrado do primeiro autor, sob orientação do segundo. Os autores agradecem à Fapesp e ao CNPq pelo apoio recebido.

2 Programa de Pós-Graduação em Psicologia do Desenvolvimento e Aprendizagem da Unesp - Bauru. 
obra. Entretanto, Skinner nunca pesquisou empiricamente quais seriam as propriedades desse comportamento.

Este trabalho pretende analisar os usos da expressão "prestar atenção" na literatura da AC na tentativa de avaliar a coerência entre as propostas de estudo do tema desenvolvidas por analistas do comportamento inspirados em Skinner e a filosofia que subjaz à AC, o Behaviorismo Radical. Espera-se criar, com este texto, subsídios a serem utilizados (1) pelo professor que ensina AC quando este é imbuído da tarefa de ensinar o que é o "prestar atenção" para esta perspectiva e (2) pelo professor de outras áreas que precise explicar qual é a visão da AC para o referido fenômeno.

A AC como disciplina científica deve avaliar as práticas de seus próprios membros nos mesmos termos que utiliza para avaliar os comportamentos de outrem, cientistas ou não (Hineline, 1992). Nesse sentido, a avaliação do "prestar atenção" na AC perpassa a análise do comportamento verbal dos próprios analistas do comportamento. Tal tarefa se mostra importante ao se constatar que diversos autores da área utilizam a expressão "prestar atenção" sob controle de eventos diferentes. Por vezes tenta-se estabelecer uma identidade entre o "prestar atenção" e alguns processos comportamentais como controle de estímulos (Skinner, 1953/1965, 1971/ 2002; Donahoe, Palmer \& Burgos, 1994; Sério, et al., 2002), o que tornaria a expressão desnecessária. Outras vezes o "prestar atenção" é considerado como um comportamento em si mesmo, como um caso de resposta de observação (Wyckoff, 1952; Skinner, 1954/1999; 1957/1999; 1961/1999; 1968; Shahan, et al., 2003). Há, ainda, quem defenda que o "prestar atenção" deve ser interpretado como um processo cerebral, não observável diretamente, ainda que, hipoteticamente, seja governado pelos mesmos princípios do comportamento operante aberto (Dinsmoor, 1985).

A diversidade de interpretações disponíveis denuncia a dificuldade da AC em explicar os eventos tradicionalmente considerados mentais. $\mathrm{O}$ desacordo entre os analistas do comportamento sobre quais relações comportamentais estão envolvidas no fenômeno "prestar atenção" dificulta também a comunicação entre os próprios 
pesquisadores e entre eles e as comunidades científicas afins: Psiquiatria, Neurologia etc. Neste texto, utilizar-se-á da estratégia de reconstrução conceitual, tal como proposta por Zuriff (1985), para avaliar o quanto as proposições conceituais presentes na literatura da AC sobre o "prestar atenção" são coerentes com os pressupostos filosóficos do Behaviorismo Radical.

\section{Considerações preliminares}

Como demonstraram Strapasson \& Dittrich (2008), Skinner trata do "prestar atenção" em diversos momentos de sua obra. Entretanto, dispõe diferentes interpretações em seus textos. A possibilidade de se encontrar uma coerência interna na obra do autor foi analisada alhures (idem, ibidem). Neste trabalho, os argumentos de Skinner serão considerados apenas na medida em que contribuírem para a reconstrução conceitual aqui empreendida. Outra consideração a ser explicitada é que este texto é produto de uma análise sistemática da literatura (Strapasson, 2008), entretanto a abrangência e estratégias metodológicas adotadas em tal revisão não serão aqui apresentadas. Essa opção se expressa no uso seletivo da bibliografia, de modo que se fará referência apenas às exposições mais emblemáticas dos argumentos aventados. Caso o leitor se interesse por detalhes da revisão ou por quais são os textos representativos de cada posição discutida, sugere-se recorrer a Strapasson (2008).

\section{O "prestar atenção" na AC}

Os analistas do comportamento têm investigado o "prestar atenção" a partir de três níveis diferentes de análise: (1) como equivalente à relação de controle de estímulos, (2) como equivalente à resposta de observação e (3) como um comportamento precorrente encoberto capaz de interferir no estabelecimento da relação de controle de estímulos. 


\section{O "prestar atenção" como relação de controle de estímulos}

É comum encontrar em textos de analistas do comportamento a interpretação de que o "prestar atenção" corresponde à existência do controle de estímulos. Sugere-se, nesse caso, que o "prestar atenção" não seria um comportamento propriamente dito, mas sim uma relação de controle: "[...] atenção não é uma forma de comportamento. [...] Atenção é uma relação de controle - a relação entre uma resposta e um estímulo discriminativo. Quando alguém está prestando atenção ele está sob controle especial de um estímulo" (Skinner, 1953/1965, p.123). Reynolds (1961, p.208) corrobora essa interpretação: "[...] atenção se refere à relação de controle entre os estímulos e o responder. Um organismo atenta a um estímulo quando seu responder está sob controle daquele estímulo”. Os autores que sugerem essa interpretação (Sério, et al. 2002) supõem que um psicólogo (ou outro sujeito qualquer), ao atestar que um organismo presta atenção, está sob controle do efeito diferencial que um estímulo tem sobre o comportamento do organismo, ou seja, ele verifica a ocorrência de controle de estímulos. Nesse sentido, praticamente todo comportamento operante envolveria o "prestar atenção" e o termo seria desnecessário em uma ciência do comportamento.

A reivindicação pelo abandono da expressão parece seguir a mesma lógica disposta por Skinner (1938/1991, p.6-8) quanto ao uso de termos não comportamentais:

A maioria desses termos [os do senso comum e os de outras teorias psicológicas] deve ser evitada na descrição científica do comportamento. [...] A objeção importante ao vernáculo na descrição do comportamento é que muitos desses termos implicam esquemas conceituais. Isso não significa que nós devemos abandonar completamente o discurso ordinário em uma ciência do comportamento. O único critério para a rejeição de um termo popular é a implicação de um sistema ou de uma formulação estendida para além das observações imediatas. 
O "prestar atenção", nessa lógica, seria um termo demasiado comprometido com outros esquemas conceituais e deveria ser eliminado do vocabulário da $\mathrm{AC}$ em prol do uso de expressões mais descritivas, como "controle de estímulos". Caso adotada, essa estratégia teria a vantagem de garantir, sem a necessidade de recorrer a muitos condicionantes, a coerência com a avaliação do evento dentro de uma análise de contingências, evitando-se recorrer a instâncias volitivas e/ou mentalistas (Zuriff, 1985). Outro efeito positivo da adoção dessa estratégia é a possibilidade de o analista do comportamento, mesmo sem modificar os métodos clássicos empregados em suas pesquisas, poder reivindicar que está estudando a atenção, eliminando assim uma eventual acusação de negligência do tema. Por fim, a pesquisa sobre as condições necessárias para a produção de controle de estímulos pode gerar tecnologia que permitirá a intervenção em situações em que é preciso aumentar as chances de que um estímulo ganhe controle sobre o comportamento do sujeito.

Por outro lado, algumas objeções podem ser levantadas contra a eliminação do conceito de "prestar atenção" na Análise do Comportamento. A primeira delas se refere ao fato de que alguns analistas do comportamento continuaram usando a expressão "prestar atenção" para descrever relações de controle de estímulos (Fantino \& Logan, 1979; Nevin, et al., 2005) e, portanto, a recomendação simplesmente parece não ter afetado os pesquisadores da área. Uma segunda crítica é que Skinner abandona a postura eliminativista ao longo de sua carreira em favor da análise de termos psicológicos como uma análise do comportamento verbal dos cientistas (Skinner, 1945/1984). Nenhuma dessas objeções é expressiva, pois o fato de que uma recomendação não foi adotada não significa que ela não seja pertinente e o fato de que Skinner deixou de eliminar termos de outras teorias não implica a necessidade de outros autores fazerem o mesmo.

Outro conjunto de objeções, entretanto, tem implicações mais significativas para a discussão do tema. A primeira delas diz respeito à impossibilidade da igualação do "prestar atenção" com o controle de estímulos em explicar o efeito dos sistemas auxiliares de resposta que alteram o próprio estabelecimento de controle de estímulos 
(e.g. respostas de orientação etc.). Olhar para o local onde os estímulos serão dispostos é condição necessária para o estabelecimento de uma relação de controle entre os estímulos dispostos e as respostas do organismo. Seguindo esse raciocínio, é fácil supor que outras respostas equivalentes, mas mais sutis, como diferenciar figura $e$ fundo, possam ser tão importantes quanto olhar para os estímulos. A segunda, derivada da primeira, se refere ao fato de que ignorar respostas precorrentes que permitam ou melhorem o controle de estímulos implica ignorar parte do que se pesquisa sob o rótulo de "atenção" na Psicologia como um todo e deixa espaço para críticas de que a $\mathrm{AC}$, apesar de não negligenciar o tema, analisa-o apenas parcialmente.

\section{"Prestar atenção" como comportamento precorrente}

Uma proposição alternativa à anterior é interpretar o "prestar atenção" como uma resposta auxiliar que estabelece ou aprimora o controle de estímulos. Essa proposição implica um modelo de dois estágios no estudo da "atenção": primeiro, o organismo atenta a um estímulo ou a uma propriedade de um estímulo e depois responde apropriadamente a esse estímulo (Wyckoff, 1952, 1969; Zeaman \& House, 1963; Mackintosh, 1965b, 1975; Skinner, 1968; Hamlin, 1975). O primeiro elo nessa cadeia de comportamentos, que estamos indicando aqui como o "prestar atenção", foi conceituado de várias formas (resposta de orientação, resposta de atenção, resposta de observação, atentar etc.), mas essas conceituações podem ser separadas em dois grupos diferentes: (1) Respostas de observação e (2) "Atentar". Esses agrupamentos se aproximam ao defender a análise do fenômeno em dois estágios, mas diferem conceitualmente quanto à abrangência do fenômeno e em suas implicações filosóficas. 


\section{"Prestar atenção" como resposta de observação}

A expressão "resposta de observação" (doravante RO) foi cunhada por Wyckoff(1952, p.431) para estudar o que os teóricos da aprendizagem de discriminação vinham chamando, à época, de predisposição para aprender respostas diferenciais a um par de estímulos:

Tal predisposição vem sendo frequentemente atribuída a alguma reação do S[ujeito] como uma resposta de atentar, resposta de orientação, resposta de percepção, atividade de organização sensorial, etc. [...] Vamos adotar o termo "resposta de observação" para fazer referência a qualquer resposta que resulta na exposição a um par de estímulos discriminativos. (grifo acrescido)

Wyckoff utilizou uma caixa operante para pombos na qual animais eram ensinados a responder em um disco sob um esquema misto MIX -VI3/EXT que poderia ser transformado em esquema múltiplo com os mesmos componentes (MULT-VI3/EXT ${ }^{3}$ ) enquanto o animal mantivesse pressionado um pedal que ficava próximo ao disco. Nesse delineamento, a emissão da RO não altera as possibilidades de obtenção de reforço pelo animal. Segundo Wyckoff (1952, p.240), "em certo sentido, o sujeito não ganhava nada além de informação ao emitir a resposta de observação”. A proposição de Wyckoff criou um paradigma experimental, que posteriormente foi utilizado principalmente no estudo do reforçamento condicionado (Dinsmoor, 1983a) e caracterizou claramente uma abordagem de dois estágios no estudo do "prestar atenção".

É comum encontrar na literatura quem aponte uma identidade entre a RO e o comportamento atentivo (Kelleher, 1958; Zearman \& House, 1963), bem como quem negue essa identificação (e.g.

3 Esse é um arranjo experimental em que dois esquemas de reforço se alternam sem nenhuma sinalização para o sujeito. Nesse caso, os esquemas que variavam era um esquema de Intervalo Variado (VI) de três minutos e um esquema de extinção (EXT). O esquema múltiplo segue a mesma lógica, mas inclui sinalização. 
Mackintosh, 1965b, 1975; Hendry, 1969; Dinsmoor, 1985): “A RO tem sido considerada como 'comportamento atentivo', mas o papel da atenção na percepção e aprendizagem animal certamente fica aquém do que é exemplificado pelo comportamento aberto" (Hendry, 1969, p.23).

A dificuldade em identificar a RO com o "prestar atenção" está ligada ao uso que se tem feito dela na pesquisa experimental. A noção de RO surge na tentativa de operacionalizar a "predisposição dos sujeitos a responder diferencialmente a um par de estímulos discriminativos" (Wyckoff, 1952, p.431), de modo que a pesquisa empírica sobre o assunto fosse possível. Em sua proposição original, o conceito não se limita às respostas abertas observadas pelos pesquisadores, mas, na prática, os cientistas utilizam a expressão para se referir apenas a essas respostas. ${ }^{4}$ Desse modo, a maior parte das críticas sobre a insuficiência desse conceito em explicar o "prestar atenção" se dirige à reivindicação de que a RO não englobaria as respostas encobertas possivelmente componentes do(s) "sistema(s) atentivo(s)" (Hendry, 1969). Mackintosh (1965b) defende essa posição ao debater resultados experimentais publicados por ele mesmo em 1965 (idem, 1965a):

Se ratos são treinados em discriminações entre um retângulo horizontal preto e um vertical branco, não há maneira concebível em que eles possam se orientar para olhar para a diferença na orientação entre os estímulos sem ver a diferença no brilho (e vice-versa). Assim, demonstrações de atenção seletiva entre essas dimensões decisivamente excluem qualquer interpretação em termos de respostas de orientação. (idem, 1965b, p.143)

4 Essa característica é um produto natural da abordagem experimental em AC. Para se manipular com segurança uma variável é preciso poder aferi-la com precisão e isso só é possível se essa variável for observável (Dittrich et al., 2009). Essa estratégia não limita o conceito, mas afeta diferencialmente autores favoráveis e desfavoráveis à possibilidade de explicar o "prestar atenção" por meio da noção de RO. 
Em vista dessa dificuldade em se identificar a noção de "prestar atenção" com o uso comum que se dava ao conceito de RO, trabalhos como os de Dinsmoor (1983b, 1985), Shahan, Magee \& Dobberstein (2003) e Nevin, Davidson \& Shahan (2005), entre outros, assumem a postura de que a RO deve ser considerada apenas um análogo do "prestar atenção":

Nós somos obrigados a considerar processos análogos [à observação] [...] comumente conhecidos como atenção. Os processos envolvidos na atenção não são prontamente acessíveis à observação como são os ajustamentos mais periféricos, mas é minha esperança e minha hipótese de trabalho que eles obedecem a princípios similares. (Dinsmoor, 1985, p.365)

Assim, ainda que "[a noção de prestar] atenção seja usualmente construída como um processo cognitivo, nós vemos a atenção como um comportamento operante (possivelmente encoberto) não mensurado que acompanha o comportamento mensurado de observação" (Nevin et al., 2005, p.281). Portanto, o "prestar atenção” se diferencia do RO na medida em que o primeiro é encoberto e o segundo é aberto.

A interpretação do "prestar atenção" como RO tem como vantagens: (1) a identificação de ao menos um sistema auxiliar de respostas que determina (ainda que apenas parcialmente) o estabelecimento de controle de estímulos; (2) aprimora nosso conhecimento sobre o reforçamento condicionado; (3) na medida em que identifica essas respostas auxiliares, permite o desenvolvimento de tecnologias que as prevejam e manipulem em contextos aplicados; e (4) enfatiza o papel ativo do sujeito no estabelecimento de controle de estímulos (nãoé mais apenas a configuração/disposição dos estímulos ou propriedades destes que determina o controle de estímulos, o sujeito emite respostas que interferem nesse controle). Por outro lado, ao assumir que as ROs não representam a totalidade das respostas auxiliares precorrentes que determinam o controle de estímulos, essa proposta parece incompleta e adicionalmente cria a dificuldade para 
o pesquisador de ter que diferenciar os efeitos desses dois componentes precorrentes (as ROs e o "prestar atenção"): "do ponto de vista comportamental, nós podemos abordá-la [a atenção] apenas indiretamente, e nós devemos enfrentar a difícil tarefa de distinguir os efeitos comportamentais em cada instância daqueles a serem atribuídos a mudanças na observação" (Dinsmoor, 1985, p.365).

Alguns autores aproveitaram-se do fato de que o uso experimental da noção de RO deixava parte do "prestar atenção" de fora para propor mais um evento precorrente mediador do controle de estímulos. Utilizaremos o termo "Atentar" (entre aspas e com a letra inicial maiúscula) para designar esse evento daqui em diante.

\section{"Atentar"}

A necessidade do conceito de "Atentar" pode ser exemplificada pelo primeiro conjunto de resultados relatados no estudo de Zeaman \& House (1963). Nesse trabalho, os autores analisaram os desempenhos em treinos de discriminação simultânea simples de cinquenta crianças com problemas de desenvolvimento e perceberam grande variabilidade quanto ao número de sessões necessárias para os sujeitos alcançarem o critério de discriminação estabelecido (de dez a 150 blocos de treino distribuídos em até seis dias de treino). Contudo, observou-se também que, se agrupados quanto ao número de blocos de treino necessários para atingir o critério após o início de mudança no desempenho, os sujeitos exibiam padrões bastante próximos (todos os grupos melhoraram rapidamente o desempenho nos últimos dez ou vinte blocos de treino, independente do número total de blocos necessários). Os grupos permaneceram tempos consideravelmente diferentes com desempenhos de discriminação próximos do acaso, mas uma vez que começavam a melhorar a performance, atingiam o critério de forma relativamente rápida. Zeaman \& House (idem) interpretaram esses resultados como sendo efeito do comportamento de "Atentar": os sujeitos permaneceram "discriminando" em níveis próximos do acaso porque não aten- 
taram às propriedades relevantes dos estímulos na tarefa; uma vez que aprendam a atentar a tais estímulos aprimoram seus desempenhos atingindo rapidamente o critério estabelecido (idem, ibidem). Uma das principais conclusões do estudo é que parte do que deve ser ensinado em uma tarefa de discriminação é o "prestar atenção" aos estímulos discriminativos relevantes.

Essa proposição sobre o "prestar atenção" é também um modelo de dois estágios na interpretação do fenômeno, entretanto difere da RO na medida em que não pretende investigar empiricamente o primeiro elo da cadeia (o "Atentar"). Os teóricos da "atenção" assim compreendida (Zeaman \& House, 1963; Mackintosh, 1965, 1975; Hendry, 1969) recorrem a diversos experimentos empíricos para avaliar o "prestar atenção", mas esses experimentos não avaliam diretamente as respostas de "atentar", apenas inferem o primeiro elo a partir dos desempenhos obtidos.

Teorias do "Atentar" diferem da identificação do "prestar atenção" com o controle de estímulos por assumirem dois estágios na explicação do comportamento e diferem da explicação que se utiliza do conceito de RO por não avaliarem diretamente o primeiro dos dois estágios assumidos. Adicionalmente, é comum encontrar entre autores desse grupo o argumento de que é vantajoso interpretar o "prestar atenção" dessa forma justamente por não se prender aos resultados obtidos com respostas abertas como as ROs:

Não há evidências que suportem o pressuposto de que a atenção e respostas de escolha [ou de observação] obedeçam exatamente às mesmas leis, e a possibilidade de alterar os parâmetros independentemente um do outro gera explicações que abrangem uma maior variedade de dados comparativos [entre espécies]. (Mackintosh, 1965b, p. 145)

Com essa liberdade teórica pode-se indicar, por exemplo, que o "prestar atenção" tem natureza diversa dos processos comportamentais operantes (i.e., é um evento cognitivo ou neurofisiológico):

Presume-se que ROs seguem as mesmas leis [do comportamento operante], tal como aquisição e extinção, como qualquer outra respos- 
ta, enquanto que hipóteses [sobre o Atentar] são estados cognitivos, não necessariamente vinculados às leis do hábito. (Zeaman \& House, 1963, p.214)

Em outro momento do mesmo texto, ao avaliar os efeitos da novidade (novelty) dos estímulos sobre o "prestar atenção", Zeaman \& House (idem, p.200) defendem que o "Atentar" é um processo central, possivelmente neurofisiológico:

Os efeitos da novidade nos apresentam um paradoxo, que só pode ser resolvido assumindo-se que a atenção é um processo central. [...] Um estímulo não pode ser julgado novo exceto em relação a séries anteriores ou a um contexto de estímulos antigos (familiar). Mas esse julgamento deve requerer que o sujeito mantenha algum traço, gravação ou engrama dos estímulos prévios (familiares) para contrastar com o sinal novo presente. [...] Sujeitos que falham na discriminação por causa da inatenção estão armazenando informações sobre o estímulo em algum lugar. Atenção é, portanto, um processo central.

O fato de teóricos que defendem as teorias do "Atentar" (não se prenderem aos resultados obtidos com respostas observáveis e não terem a mesma natureza dos processos comportamentais até então estudados) é contrário, ao menos em alguns aspectos, às proposições do Behaviorismo Radical.

Skinner diferencia o Behaviorismo Radical de outros behaviorismos, entre outros argumentos, defendendo que não se deve ignorar os eventos que não se pode observar ou medir (Skinner, 1963/1984). Na medida em que se afasta do Operacionismo Clássico e do Positivismo Lógico, Skinner permite e incentiva o uso da inferência como recurso legítimo da ciência em geral e da AC em particular (Skinner, 1984; Dittrich et al., 2009); contudo, usa uma concepção específica de inferência: "eu a definiria como o uso de termos e princípios científicos para falar de fatos sobre os quais se sabe muito pouco para tornar possíveis a previsão e o controle" (Skinner, 1984, p.578), e alerta para os perigos de se inferir sem tomar os resultados experimentais conhecidos como base última da interpretação (idem, 1953/1965). Se Skinner 
concebe que a inferência sobre os eventos privados deve ser baseada nos resultados experimentais obtidos até o momento, é possível argumentar que, para ele, assumir a postura "não há motivos para se inferir que os eventos inobserváveis têm natureza diferente dos eventos observáveis" (postura semelhante à de Dinsmoor, 1985) seria preferível em relação à postura "não há motivos para se assumir que os eventos encobertos seguem as mesmas leis dos comportamentos abertos", como parece ser a posição de Mackintosh (1965b), por exemplo. Obviamente, a posição de Dinsmoor (1985) de que o "Atentar" segue as mesmas leis do comportamento operante também é uma inferência, mas é uma inferência muito mais próxima daquela defendida por Skinner (1971/2002, p.22-3), afinal:

Muitas vezes referimo-nos a coisas que não podemos observar ou medir com a precisão demandada por uma análise científica, e, ao fazêlo, há muito a se ganhar ao usar termos e princípios que foram forjados em condições mais precisas.

Quanto ao assumir que o "Atentar" é necessariamente um processo central (i.e. neurofisiológico), os argumentos apresentados por Zeaman \& House (1963) parecem refletir séria incompreensão das propostas behavioristas radicais. Se o fato de os organismos responderem diferencialmente a certos estímulos que foram apresentados no passado, mas não estão presentes na situação atual, fosse prova da existência de uma unidade conceitual como engrama ou representação, a AC não teria o que dizer sobre o fenômeno da memória sem recorrer à neurofisiologia, o que, não obstante, ela faz com frequência. Para a AC, um organismo que passou por certa experiência com um determinado estímulo teve seu comportamento modificado pelo papel que esse estímulo desempenhou naquele ambiente (seja como reforçador, como contexto $-\mathrm{S}^{\mathrm{D}}$ etc.). O que resulta dessa interação é um organismo modificado que reagirá diferentemente caso venha a ser exposto a um ambiente parecido no futuro. Não é necessário assumir um "julgamento interno" do estímulo que avalie se ele é novo ou familiar. O organismo reage diferencialmente a ele 
porque foi (ou não) exposto a contingências que o tornaram importante. Os detalhes sobre como o organismo é modificado não são de competência da AC, apenas disciplinas como a Fisiologia e a Bioquímica têm os métodos adequados para descrever esse fenômeno. Contudo, a AC pode perfeitamente prescindir desses métodos e continuar a prever e controlar o comportamento dos organismos. Nesse caso específico, é necessário apenas conhecer a história que o organismo tem em relação ao estímulo de interesse.

\section{Uma síntese possível da reconstrução conceitual}

De modo geral, parece que restam duas opções ao analista do comportamento quando tenta conceituar o "prestar atenção": ou (1) ele segue uma postura "eliminativista" e assume que, havendo um termo menos carregado historicamente de características mentalistas (i.e. controle de estímulos), a expressão "prestar atenção" nãoé necessária e deve ser evitada, ou (2) ele segue uma postura mais "compreensiva" e conceitua o "prestar atenção" como um sistema complexo de comportamentos que pode ser analisado em vários níveis, como a verificação da presença de controle de estímulos ou o estudo de comportamentos precorrentes, sejam eles encadeados ou ROs, mas que interfiram no controle diferencial exercido por um estímulo. A diferença nas duas proposições pode ser interpretada como uma diferença na abrangência da classe de respostas a que se refere a expressão "prestar atenção" (Strapasson \& Dittrich, 2008), contudo a coexistência das duas proposições não resolve o principal problema da pesquisa sobre o tema, a multiplicidade de sentidos em que a expressão é utilizada. É necessário, portanto, avaliar os benefícios alcançados com cada uma das formas de abordar o "prestar atenção" e, eventualmente, optar por uma delas.

Assumir a primeira postura evita os sistemas conceituais comumente associados à expressão "prestar atenção" na literatura psicológica ampla e no senso comum, e é coerente com a prática skinneriana de se abandonar os termos que carregam esses esque- 
mas conceituais, retomando-os apenas quando justificativas sistemáticas tiverem sido obtidas (Skinner, 1938/1991). Entretanto, o fato de os estudos experimentais ainda não terem conseguido acessar diretamente os eventos (até o momento) encobertos considerados como influentes no estabelecimento de controle de estímulos, pode ser indicado como uma justificativa para a permanência da expressão. Com efeito, para se alcançar plenamente os benefícios dessa postura, seria necessário substituir a expressão "prestar atenção" pela expressão "comportamento precorrente", pois só assim a AC poderia descrever os fenômenos sob esse rótulo apenas com termos próprios, desvinculados dos problemáticos esquemas conceituais divergentes. Essa é uma postura legítima na AC, mas pode contribuir com o que Krantz (1971) indicava como isolamento da AC da Psicologia como um todo e a dificuldade cada vez maior de comunicação entre a AC e áreas afins (ver debate no JEAB, v.60, de 1993, sobre a possibilidade de a AC se reaproximar da Psicologia sem abrir mão de suas características fundamentais).

Assumir a segunda postura, apesar de exigir do pesquisador que clarifique o sentido em que usa a expressão "prestar atenção" (para não ser acusado de recorrer a instâncias mentalistas), se aproxima mais da interpretação, a qual se sugeriu ser a de Skinner (Strapasson \& Dittrich, 2008), de que o "prestar atenção" pode ser avaliado em vários níveis de análise. Essa postura também é plenamente legítima no Behaviorismo Radical, uma vez que não inclui nenhum evento mentalista, mediador ou iniciador do comportamento de "prestar atenção”. Além disso, em se tratando de uma tradução conceitual dessa expressão, as consequências úteis de uma tradução poderão ser mais amplamente alcançadas (Strapasson et al., 2007), especialmente as consequências políticas de maior disseminação das propostas da AC e a consequente melhor comunicação entre esta e disciplinas afins.

Sendo as duas propostas compatíveis com a AC, na medida em que uma prescrição política possa ser indicada como critério de escolha entre as duas proposições, dever-se-ia optar pela segunda em prol da sobrevivência da AC enquanto prática cultural. 


\section{Referências bibliográficas}

DINSMOOR, J. A. Observing and conditioned reinforcement. Behavioral and Brain Sciences, v.6, p.693-704, 1983a.

Some more information on observing and some more observations on information. Behavioral and Brain Sciences, v.6, p.718-24, 1983b.

The role of observing and attention in establishing stimulus control. Journal of the Experimental Analysis of Behavior, v. 43, p.36581, 1985.

DITTRICH, A. et al. Sobre a observação enquanto procedimento metodológico na análise do comportamento: positivismo lógico, operacionismo e behaviorismo radical. Psicologia: teoria e pesquisa, v.25, p.179-87, 2009.

DONAHOE, J. W.; PALMER, D. C.; BURGOS, J. E. Learning and complex behavior. Boston: Allyn and Bacon, 1994.

FANTINO, E.; LOGAN, C. A. The experimental analysis of behavior: a biological perspective. San Francisco: Freeman, 1979.

HAMLIN, P. H. Observing responses as an index of attention in chickens. Journal of Experimental Psychology: animal behavior processes, v.1, p.221-34, 1975.

HENDRY, D. P. Introduction. In: (Org.). Conditioned reinforcement. Illinois: The Dorsey Press, 1969, p.1-33.

HINELINE, P. H. A self-interpretive Behavior Analysis. American Psychologist, v.47 n.11, p.1274-86, 1992.

KELLEHER, R. T. Stimulus-producing responses in chimpanzees. Journal of the Experimental Analysis of Behavior, v.1 n.1, p.87-102, 1958.

KRANTZ, D. The separate worlds of operant and non-operant psychology. Journal of Applied Behavior Analysis. v.4, p.61-70, 1971.

MACKINTOSH, N. J. The effect of attention on the slope of generalization gradients. British Journal of Psychology, v.56, p.8793, 1965a.

Selective attention in animal discrimination learning. Psychological Bulletin, v.64, p.124-50, 1965b.

A theory of attention: variations in associability of stimuli with reinforcement. Psychological Review, v.82, p.276-98, 1975. 
NEVIN, J. A.; DAVISON, M.; SHAHAN, T. A. A theory of attending and reinforcement in conditional discriminations. Journal of the Experimental Analysis of Behavior, v.84 n.2, p.281-303, 2005.

REYNOLDS, G. S. Attention in the pigeon. Journal of the Experimental Analysis of Behavior, v.4, p.203-8, 1961.

SCHROEDER, S. R.; HOLLAND, J. G. Reinforcement of eye movement with concurrent schedules. Journal of the Experimental Analysis of Behavior, v.12 n.6, p.897-903, 1969.

SÉRIO, T. M. A. P.; ANDERY, M. A.; GIOIA, P. S. MICHELETTO, N. Controle de estímulos e comportamento operante: uma introdução. São Paulo: Educ, 2002.

SHAHAN, T. A.; MAGGE, A.; DOBBERSTEIN, A. The resistance to change of observing. Journal of the Experimental Analysis of Behavior, v.80 n.3, p.273-93, 2003.

SKINNER, B. F. Behavior of organisms. Acton, MA: Copley Publishing Group, 1991 (Obra originalmente publicada em 1938).

The operational analysis of psychological terms. Behavior and Brain Sciences, v.7 n.4, p.547-53, 1984. (obra originalmente publicada em 1945)

Science and human behavior. New York: Macmillan, 1965 (obra originalmente publicada em 1953).

The science of learning and the art of teaching. In: LATIES, V. G.; CATANIA, A. C. (Orgs.). Cumulative record. Definitive edition. Acton: Copley Publishing Group, 1999, p179-91. (obra originalmente publicada em 1954).

The experimental analysis of behavior. American scientist, v.45, p.343-71, s. d.

Why we need teaching machines? In: LATIES, V. G.; CATANIA, A. C. (Orgs.). Cumulative record. Definitive edition. Acton: Copley Publishing Group, 1999, p.217-239. (obra originalmente publicada em 1961)

. Behaviorism at fifty. Behavior and Brain Sciences, v.7 n.4, p.615-20, 1984. (obra originalmente publicada em 1963)

Teaching thinking. In: (Org.) The Technology of teaching. New York: Meredith Corporation, 1968, p.115-44.

Beyond freedom and dignity. Indianapolis: Hackett Publishing Company, 2002. (obra originalmente publicada em 1971). 
Coming to terms with private events. Behavior and Brain Sciences, v.7 n.4, p.572-9, 1984.

STRAPASSON, B. A. O conceito de "prestar atenção" na Análise do Comportamento de B. F. Skinner. Dissertação (mestrado em Psicologia do Desenvolvimento e Aprendizagem). Unesp, Bauru, 2008. 271p.

; CARRARA, K.; LOPES JUNIOR, J. Consequências da interpretação funcional de termos psicológicos. Revista Brasileira de Terapia Comportamental e Cognitiva, v.9, p.227-39, 2007.

; DITTRICH, A. O conceito de "prestar atenção" para Skinner. Psicologia: teoria e pesquisa, v.29, p.519-26, 2008.

WYCKOFF, L. B. The role of observing responses in discrimination learning. Psychological Review, v.59 n.6, p.431-42, 1952.

ZEAMAN, D.; HOUSE, B. J. The role of attention in retardate discrimination learning. In: ELLIS, N. R. (Org.). Handbook of mental deficiency. New York: McGraw-Hill, 1963, p.159-73.

ZURIFF, G. E. Behaviorism: a conceptual reconstruction. New York: Columbia University Press, 1985. 
PARTE III

\section{Habilidades SOCIAIS E RELAÇÕES EDUCATIVAS}





\title{
10 \\ INVESTIGANDO AS HABILIDADES SOCIAIS DE PRÉ-ESCOLARES COM PROBLEMAS DE COMPORTAMENTO ${ }^{1}$
}

\author{
Vanessa Barbosa Romera Leme ${ }^{2}$ \\ Alessandra Turini Bolsoni-Silva ${ }^{3}$
}

\section{Introdução}

O campo teórico e prático de Treinamento de Habilidades Sociais (THS) vem desenvolvendo diversos estudos sobre como melhorar a relação escola-aluno-família por meio de programas que procuram articular pesquisas de relacionamento interpessoal com os objetivos acadêmicos (Del Prette \& Del Prette, 2001). A maioria dessas pesquisas investiga tanto as relações entre pares aluno-professor quanto aquelas entre escola-família e indica que problemas comportamentais infantis são frequentemente mantidos tanto pelo ambiente escolar quanto pelo familiar.

1 Este estudo é um recorte da dissertação de mestrado da primeira autora, sob orientação da segunda autora, cujo título é Habilidades sociais e problemas de comportamento de pré-escolares e a sua relação com as Habilidades Sociais Educativas Parentais. Defendida no Programa de Pós-Graduação em Psicologia do Desenvolvimento e Aprendizagem.

2 Programa de Pós-Graduação em Psicologia da Faculdade de Filosofia, Ciências e Letras da Universidade de São Paulo - USP - FFCLRP.

3 Programa de Pós-Graduação em Psicologia do Desenvolvimento e Aprendizagem da Unesp - Bauru. 


\section{Habilidades sociais na infância}

Apesar de não haver um consenso na literatura quanto à definição do termo "habilidades sociais", Del Prette \& Del Prette (2005, p.31) afirmam que este tem sido geralmente utilizado para representar "diferentes classes de comportamentos sociais do repertório de um indivíduo, que contribuem para a competência social, favorecendo um relacionamento saudável e produtivo com as demais pessoas". Conforme Del Prette \& Del Prette (2006), as habilidades sociais são sempre situacionais, isto é, um mesmo desempenho social pode ser considerado desejável e, dessa forma, contribuir para a competência social em um determinado contexto e não em outro.

Para Del Prette \& Del Prette (2005), é na infância que se inicia a aprendizagem das habilidades sociais e das normas de convivência, a qual ocorre primeiramente com a família, por meio das práticas educativas parentais, e depois em outros ambientes, como a vizinhança, a pré-escola e a escola. A importância do desenvolvimento das habilidades sociais na infância deve-se há possibilidade de prevenção (De Salvo; Mazzarotto \& Löhr, 2005) de muitas dificuldades interpessoais que podem repercutir em várias fases do ciclo vital (Caballo, 1996; Del Prette \& Del Prette, 2002). Nesse sentido, a infância é considerada um período crítico para a aprendizagem das habilidades sociais porque, principalmente na idade pré-escolar, as crianças têm seus primeiros contatos fora de seu ambiente familiar (De Salvo, Mazzarotto \& Löhr, 2005).

Alguns estudos realizados no contexto nacional concluíram que crianças com indicativos de problemas de comportamento apresentam também muitas habilidades sociais, ainda que com menos frequência quando comparado com crianças sem problemas de comportamento (Bolsoni-Silva \& Del Prette, 2003; Bolsoni-Silva \& Marturano, 2006; Silva, 2000). Outras pesquisas sinalizaram uma correlação positiva entre a competência social na infância com um melhor relacionamento com pares (Castro, Melo 
\& Silvares, 2003) e o desenvolvimento da empatia ${ }^{4}$ como fator de proteção para problemas de comportamento (Falcone, 2000; Pavariano, Del Prette \& Del Prette, 2005).

Frente a esses dados, Del Prette \& Del Prette (2005) realizaram um estudo identificando os principais trabalhos sobre habilidades sociais na infância e propuseram um programa de Treinamento de Habilidades Sociais com Crianças, contemplando as seguintes habilidades: a) autocontrole e expressividade emocional (reconhecer $\mathrm{e}$ nomear as próprias emoções e a dos outros, controlar a ansiedade, falar sobre emoções e sentimentos); b) civilidade (cumprimentar as pessoas, despedir-se, fazer e aceitar elogios, seguir regras ou instruções, fazer perguntas, responder perguntas, chamar o outro pelo nome); c) empatia (observar, prestar atenção, ouvir e demonstrar interesse pelo outro, reconhecer/inferir sentimentos do interlocutor); d) assertividade (expressar sentimentos negativos, falar sobre as próprias qualidades ou defeitos, concordar ou discordar de opiniões, fazer e recusar pedidos, lidar com críticas e gozações); e) solução de problemas interpessoais (acalmar-se diante de uma situação problema, pensar antes de tomar decisões, reconhecer e nomear diferentes tipos de problemas); f) fazer amizades (fazer perguntas pessoais, responder perguntas, sugerir atividade, elogiar, aceitar elogios, oferecer ajuda, iniciar e manter conversação); g) habilidades sociais acadêmicas (seguir regras ou instruções orais, observar, prestar atenção, ignorar interrupções dos colegas, aguardar a vez para falar, fazer e responder perguntas, oferecer, solicitar e agradecer ajuda, cooperar e participar de discussões).

4 Conforme Pavariano, Del Prette \& Del Prette (2005), as habilidades sociais contemplam uma classe de comportamentos denominada empatia, que se refere à capacidade de se "colocar no lugar da outra pessoa" por meio da manifestação de reações que expressem a compreensão dos sentimentos da outra pessoa. 


\section{Problemas de comportamentos na infância}

A literatura a respeito de um sistema de avaliação, classificação e diagnóstico para os problemas de comportamento é bastante divergente, o que de certa forma, dificulta o desenvolvimento de estratégias de intervenção (Brioso \& Sarrià, 1995; Kaiser \& Hester, 1997). Atualmente, existe uma banalização do que seria o patológico devido à preeminência na nossa sociedade do modelo médico, o qual enfatiza as influências biológicas nos comportamentos humanos, desconsiderando fatores ambientais e culturais (Brioso \& Sarrià, 1995; Lopes, Lopes \& Lobato, 2006). Assim, os problemas de comportamento serão considerados neste trabalho como

[...] déficits e/ou excessos comportamentais que prejudicam a interação da criança com pares e adultos de sua convivência [...] e que dificultam o acesso da criança a novas contingências de reforçamento, que por sua vez, facilitariam a aquisição de repertórios relevantes de aprendizagem. (Bolsoni-Silva, 2003, p.10)

A literatura tem indicado algumas características que podem influenciar no surgimento e/ ou na manutenção dos problemas de comportamento infantil: a) há uma maior incidência em meninos do que em meninas de problemas de comportamento, especialmente os classificados como externalizantes ${ }^{5}$ (Kaiser \& Hester, 1997); b) os problemas de comportamento, quando surgem na infância, são mais difíceis de serem extintos (Campbell, 1995); c) há uma disposição para a estabilidade, isto é, os problemas de comportamento, principalmente os externalizantes, que surgem na infância podem conti-

5 Uma classificação para os problemas de comportamento comumente utilizada em várias pesquisas refere-se à desenvolvida por Achenbach \& Edelbrock (1979). Segundo esses autores, os problemas de comportamento podem ser organizados em comportamentos internalizantes (tais como retraimento, queixas somáticas e ansiedade) e externalizantes (por exemplo, agressividade, impulsividade e desobediência). 
nuar na adolescência, podendo repercutir negativamente também na vida adulta (Campbell, 1995; Kaiser \& Hester, 1997); d) os problemas de comportamento geralmente são transitórios, ou seja, podem surgir em uma determinada faixa etária e diminuir em outra (Campbell, 1995).

Muitas crianças que apresentam problemas de comportamento no ambiente escolar acabam sendo rotuladas como apresentando alguma "deficiência" e/ou "incapacidade" pessoal. Tais estigmas poderiam dificultar seu desenvolvimento social e prejudicar seu rendimento escolar (Marchesi \& Martin, 1995). Na maioria das vezes, os problemas de comportamento infantil são favorecidos e mantidos pelos contextos escolares e pelo ambiente familiar (Bolsoni-Silva \& Del Prette, 2003).

Diante disso, pesquisas procuram investigar as habilidades sociais infantis utilizando os relatos de pais e de professores, por considerarem estes como observadores privilegiados dos comportamentos das crianças (Bolsoni-Silva et al., 2006; Cia \& Braham, 2009; Feitosa, 2003). Alguns estudos indicam que pais e professores tendem a concordar ao avaliar os comportamentos das crianças (Kumpulanein et al.; 1999; Ruffalo \& Elliott, 1997). Outros, porém, sinalizam que pais e professores podem divergir quanto às avaliações sobre comportamentos das crianças (Bolsoni-Silva et al., 2006; Feitosa, 2003; Satake et al., 2003).

Bolsoni-Silva et al. (2006) realizaram um estudo com o objetivo de comparar as avaliações de mães e de professoras sobre habilidades sociais e problemas de comportamento de 24 pré-escolares indicados pelas professoras com indicativos de problemas de comportamento e 24 como sendo socialmente habilidosos. O estudo indicou que as mães perceberam mais habilidades sociais que as professoras. Entre essas habilidades estão: cumprimentar as pessoas; fazer elogios; expressar desejos, carinhos, direitos e desagrado; negociar; comunicar-se de forma positiva; fazer amigos. Os autores defendem a hipótese situacional (Achenback, McConutghy \& Howell, 1987) que considera que as crianças podem apresentar comportamentos diferentes em contextos distintos. Neste caso, a escola seria um am- 
biente que apresenta mais regras enormas de convívio social. Assim, colocaria mais exigências e traria mais dificuldade de adaptação, especialmente para as crianças com dificuldades comportamentais (Bolsoni-Silva et al., 2006). Na mesma direção, Feitosa (2003), ao comparar as avaliações de pais e de professoras sobre as habilidades sociais de 64 crianças (idade entre sete e oito anos) com e sem problemas de aprendizagem, segundo a percepção das professoras, concluiu que pais de crianças com dificuldades escolares identificaram mais habilidades sociais de oferecer ajuda, propor brincadeiras, responder perguntas e agradecer elogios do que as professoras. Ambos os estudos diferenciaram as crianças como apresentando dificuldades comportamentais/acadêmicas segundo a percepção das professoras. Nesse estudo, as crianças foram avaliadas tanto pelas mães quanto pelas professoras, ou seja, deveriam apresentar dificuldades no ambiente da família e no ambiente escolar.

Portanto, o que se verifica é que há tanto uma concordância quanto uma discordância entre avaliadores, especialmente entre pais e professores, sugerindo, assim, a necessidade de mais pesquisas que procure comparar avaliações realizadas por diferentes informantes (Dessen, Abreu \& Neto, 2000; Silvares, 2000). Além dessas questões, seria importante procurar identificar e desenvolver, no repertório comportamental dessas crianças, habilidades sociais que poderiam ser utilizadas em programas de intervenção preventivos tanto com pais quanto com professores. Deste modo, investigar não apenas as dificuldades comportamentais, mas avaliar e desenvolver as habilidades infantis, pode ajudar na prevenção de problemas de comportamento e na promoção da formação infantil de forma global, isto é, desenvolvendo a cidadania, conforme recomenda a Lei de Diretrizes e Base da Educação Nacional 9394/96. A partir das considerações mencionadas, o presente estudo teve por objetivos: (a) investigar as habilidades sociais infantis de pré-escolares com indicativos de problemas de comportamento; (b) comparar as avaliações de mães e de professoras sobre as habilidades sociais das crianças. 


\section{Método}

\section{Participantes}

Vinte mães de pré-escolares (idade média dos pré-escolares: 5,2 anos, 0,96 d.p.) com indicativos de problemas de comportamento e 19 professoras como informantes. As crianças estavam matriculadas do Jardim I ao Pré, em sete Escolas Municipais de Educação Infantil (Emei) de uma cidade do interior do estado de São Paulo com 356.680 habitantes. $^{6} \mathrm{~A}$ idade média das mães era de 31 anos (d.p. $=0,83)$. A amostra das crianças foi composta por 15 meninos e cinco meninas. A escolaridade materna era de, em média, 9,37 anos (d.p. $=0,81)$ e a renda familiar era de, em média, 933 reais. Esse estudo foi aprovado pelo Comitê de Ética em Pesquisa, com protocolo $\mathrm{n}^{\circ}$ 1175/46/01/06.

\section{Instrumentos}

Para a avaliação das habilidades sociais foi utilizado o Questionário de Respostas Socialmente Habilidosos, em suas versões para professores (QRSH-PR, Bolsoni-Silva; Marturano \& Loureiro, 2009) e pais (QCSH-Pais, Bolsoni-Silva; Marturano \& Loureiro, no prelo). Para avaliar os indicativos de problemas de comportamento, foi empregada a Escala Comportamental Infantil (ECI), também com versões para professores (Santos, 2002) e pais (Graminha, 1994). A ECI-B para professores e a ECI-A2 para pais são compostas, respectivamente, por 26 e 36 itens, que apresentam descrições de comportamentos (por exemplos, "briga frequentemente com outras crianças"; "Retorce-se, é uma criança inquieta”). Cada item tem três alternativas de resposta: o comportamento descrito se aplica (escore 2), aplica-se em parte (escore 1) ou não se aplica (escore 0 ) à criança. Todas as escalas têm pontos de corte, acima dos quais se considera

6 Fonte: Dados geográficos de Bauru: <http://www.bauru.sp.gov.br/>. 
que a criança tem problemas de comportamento (escore igual ou superior a 16, na ECI-A; igual ou superior a 9, na ECI-B). A ECI-A tem adaptação brasileira, feita em uma amostra de 1.731 crianças de três a 13 anos, com índices satisfatórios de fidedignidade e determinação de ponto de corte (Graminha, 1994). A ECI-B foi traduzida por Santos (2002), que verificou que o ponto de corte original da escala discriminava crianças com alto e baixo rendimento escolar.

O QRSH-Pais e o QRSH-PR são compostos por uma lista (a versão para pais tem 22 itens e a versão para professores tem 24 itens) com comportamentos socialmente habilidosos apresentados por crianças (exemplos: "Faz pedidos"; "Apresenta facilidade para fazer amizades"), na qual os professores e os pais devem responder se um comportamento se aplica (escore 2), aplica-se em parte (escore 1 ) ou não se aplica (escore 0 ). Os escores são somados, permitindo o escore total da criança avaliada. A partir do estudo piloto (com 13 pais/mães), realizado para a pesquisa de Silva (2000), foram definidas três categorias (Expressão de sentimento e enfrentamento, Interação social positiva e Disponibilidade social e cooperação) para o QRSH-Pais, as quais foram organizadas conforme os relatos dos pais nas entrevistas estruturadas sobre o repertório comportamental dos filhos. Bolsoni-Silva, Marturano \& Loureiro (no prelo), ao realizarem um estudo de validação do QRSH-Pais com 131 pré-escolares, encontraram índices satisfatórios de consistência interna e validade concorrente e discriminante. O QRSH-PR teve suas propriedades psicométricas avaliadas no estudo de Bolsoni-Silva, Marturano \& Loureiro (2009) com 260 pré-escolares. As autoras encontraram indicadores positivos no que se refere à consistência interna e validade concorrente e discriminante. Ambos os instrumentos (QRSH-Pais e QRSH-PR) indicaram que seus itens eram capazes de consistentemente medir o construto de habilidades sociais e diferenciar as crianças com e sem problemas de comportamento. 


\section{Procedimento de coleta e de análise de dados}

Para a seleção da amostra, 19 professoras de sete Emeis foram solicitas, após a assinatura do Termo de Consentimento Livre e Esclarecido (TCLE), a indicarem crianças com indicativos de problemas de comportamento e a responderem à ECI-B. Para participar do estudo, as crianças indicadas pelas professoras como apresentando problemas de comportamento deveriam atingir o escore da ECIB (escore e" 9). Além disso, as crianças deveriam morar com ambos os pais e estes deveriam viver em uma situação conjugal civil ou por consenso. Em seguida, as mães das crianças indicadas pelas professoras foram contatadas, para que se verificasse o interesse em participar do estudo. Nesse caso, a pesquisadora agendava um encontro na residência e/ou no local de trabalho da mãe para a coleta dos dados. Todas as mães assinaram o Termo de Consentimento Livre e Esclarecido e responderam ao ECI-A2 e ao QRSH-Pais. As crianças indicadas pelas professoras como apresentando indicativos de problemas de comportamento pela ECI-B (escore e" 9) deveriam apresentar índice clínico também na ECI-A2 (escore e" 16). Dessa forma, as crianças deveriam apresentar problemas de comportamento tanto na percepção das mães quanto na percepção das professoras. As professoras indicaram 82 crianças, mas apenas quarenta delas atenderam aos critérios de seleção. Neste texto, são apresentados os dados de vinte crianças que foram indicadas como apresentando indicativos de problemas de comportamento no ambiente familiar e escolar.

Para a análise de dados, primeiramente foram selecionados os itens do Questionário de Respostas Socialmente Habilidosas (QRSH) que estavam presentes tanto na versão para professores como na versão para pais. Em seguida, foram calculadas as médias dos itens e do escore total do QRSH, versão para professores e para pais. As habilidades sociais infantis foram divididas, conforme Bolsoni-Silva (2003), em três categorias: 1) Disponibilidade social e cooperação; 2) Interação social positiva; 3) Expressão de sentimentos e enfrentamento. 


\section{Resultados}

A seção dos resultados apresenta as avaliações realizadas pelas professoras e pelas mães sobre as habilidades sociais dos filhos. A Tabela 1 apresenta as médias dos escores dos itens e do total do QRSH, segundo as avaliações das mães e das professoras.

Considerando que o valor máximo de cada item é dois, nota-se, pela Tabela 1, que as crianças com indicativos de problemas de comportamento apresentaram médias altas na maioria das habilidades sociais, principalmente nas categorias "Disponibilidade social e cooperação" e "Interação social positiva", na percepção das mães e das professoras. Ao passo que as crianças com dificuldades comportamentais apresentaram médias mais baixas nas habilidades sociais que compõem a categoria "Expressão de sentimentos e enfrentamento", especialmente nas avaliações das mães. Verifica-se que as mães e as professoras não se diferenciaram na maioria dos itens e no total do repertório de habilidades sociais infantis. As mães, mas que as professoras, disseram que seus filhos fazem mais elogios e expressam mais carinhos. Por sua vez, as professoras, mais que as mães, perceberam que as crianças brincam com colegas com mais frequência.

\section{Discussão}

O presente estudo procurou investigar as habilidades sociais infantis de pré-escolares com indicativos de problemas de comportamento e comparar a avaliação de mães e de professoras sobre as habilidades sociais das crianças. Contudo, ressalta-se que a classificação das crianças como apresentando indicativos clínicos de dificuldades comportamentais foi utilizada como ponto de partida para o início do trabalho, mas considera-se como de fundamental importância à identificação dos comportamentos problemáticos mais do que das “crianças problema” (Lopes, Lopes \& Lobato, 2006). Portanto, o pesquisador não deve utilizar os diagnósticos apenas para categorizar e rotular os indivíduos, mas sim para tentar compreender a origem 


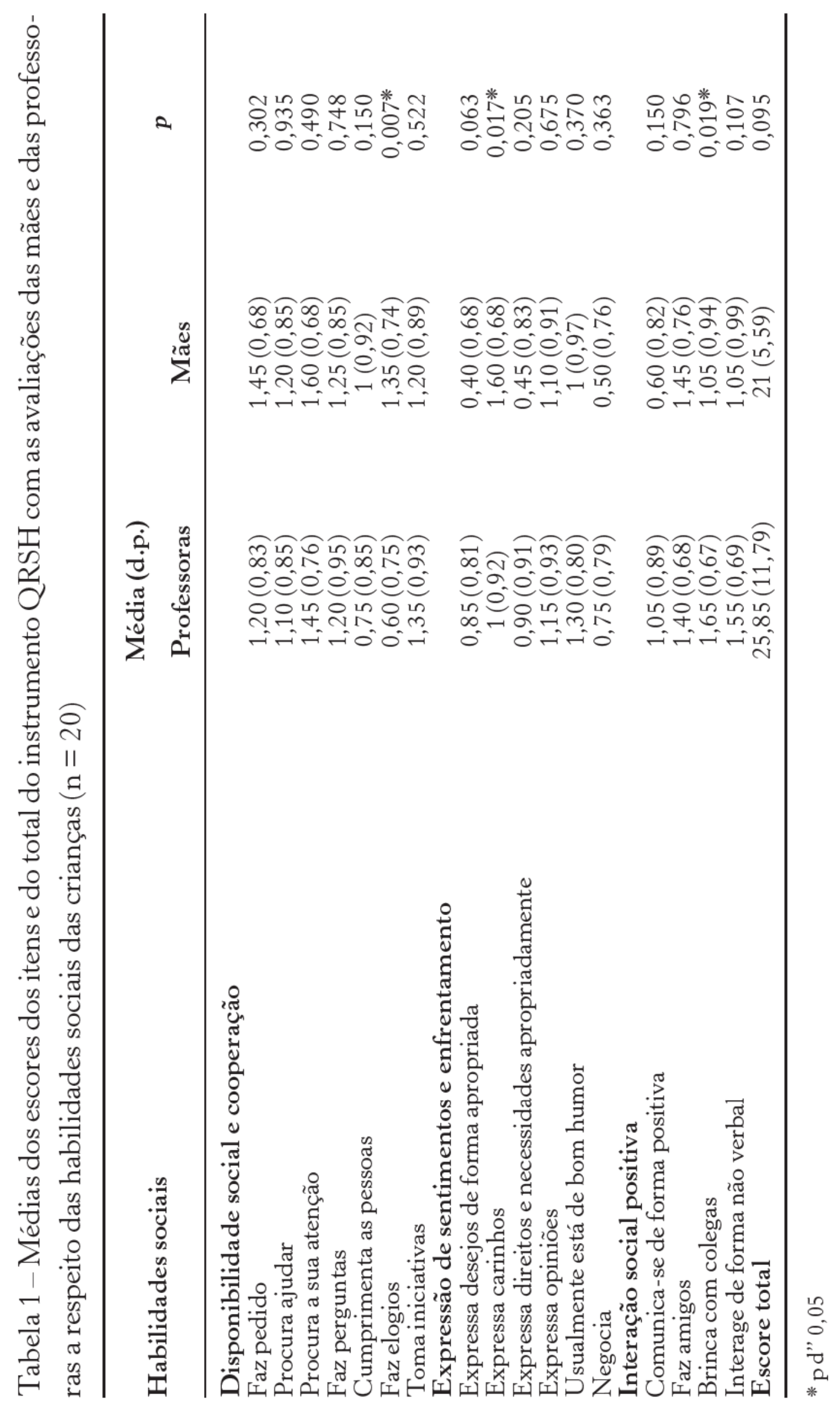


dos comportamentos problemáticos, considerando tanto fatores ambientais quanto culturais (Brioso \& Sarrià, 1995).

Os resultados indicaram que, mesmo apresentando necessidade de atendimento clínico, as crianças obtiveram médias altas na maioria das habilidades sociais investigadas, especialmente nas habilidades sociais das categorias "Disponibilidade social e cooperação" e "Interação social positiva”. Bolsoni-Silva \& Del Prette(2003), Bolsoni-Silva \& Marturano (2006) e Silva (2000) têm sinalizado que crianças com problemas de comportamento apresentam também um repertório socialmente habilidoso, ainda que com menos frequência, quando comparadas com crianças sem problemas de comportamento.

As habilidades sociais da categoria "Disponibilidade social e cooperação" contemplam, para Del Prette \& Del Prette (2005), as categorias civilidade, empatia, fazer amizades e habilidades acadêmicas. Estas, segundo os autores, são habilidades importantes não só para convívio na família, mas também na escola, em interações com pares e com professores, sinalizando possíveis reservas comportamentais que podem facilitar o desenvolvimento interpessoal da criança no ambiente escolar (Caldarella \& Merrell, 1997; Del Prette \& Del Prette, 2005).

De forma semelhante, as habilidades sociais de fazer amizades, brincar com colegas e interagir de forma não verbal, que compõem a categoria "Interação social positiva", podem ser relacionadas ao desenvolvimento da empatia e a um bom convívio social com pares. $\mathrm{O}$ desenvolvimento de um bom relacionamento com pares e da empatia tem sido indicado por alguns estudos (Falcone, 2000b; Pavariano; Del Prette \& Del Prette, 2005a) como fator de proteção para indicativos de problemas de comportamento e correlacionado positivamente com a competência social infantil.

Os resultados indicaram, ainda, que as crianças apresentaram médias baixas nas habilidades de expressar desejos, direitos, necessidades e de negociar, principalmente segundo as percepções das mães. Essas habilidades sociais fazem parte da categoria "Expressão de sentimentos e enfrentamento", a qual envolve um conjunto de comportamentos que requerem da criança, por exemplo, o auto- 
controle, a expressividade adequada de seus sentimentos e a capacidade de negociação em situações que podem envolver conflitos de interesse. Expressar sentimentos e enfrentar situações que envolvem confronto de opiniões são habilidades importantes, pois permitem à criança aprender repertórios básicos para outras habilidades mais complexas que envolvem a resolução de problemas interpessoais. Assim, por exemplo, se uma criança, durante uma brincadeira, expressa frustração e desagrado conversando e negociando, ela pode evitar agressões e manter a relação de amizade.

Parece, então, que as crianças com indicativos de problemas de comportamento apresentam, principalmente no ambiente da família, dificuldades nas habilidades de expressar sentimentos negativos, concordar e discordar de opiniões, defender os próprios direitos, lidar com críticas e negociar interesses conflitantes da categoria definida por Del Prette \& Del Prette (2005) como autocontrole e expressividade emocional e assertividade. Tais resultados indicam que as crianças do estudo apresentam algumas dificuldades diante de certas demandas do ambiente, o que sugere a importância de a escola e a família monitorarem e darem suporte nesses momentos, fornecendo modelos e incentivando comportamentos socialmente habilidosos.

Os resultados indicaram que mães e professoras concordaram na maioria dos itens e no total do repertório de habilidades sociais das crianças. Esses resultados estão coerentes com as pesquisas que demonstram que pais e professores apresentam opiniões semelhantes ao avaliar os comportamentos dos filhos (Kumpulanein et al.; 1999; Ruffalo \& Elliott, 1997). Entretanto, esses resultados podem ser decorrência da própria metodologia do estudo, que adotou como critério de inclusão que as crianças apresentassem problemas de comportamento segundo as percepções das mães e das professoras. Outros estudos indicam que pais e professores fazem avaliações diferenciadas dos comportamentos das crianças (Bolsoni-Silva et al., 2006; Feitosa, 2003; Satake et al., 2003). Nesse sentido, verificou-se que as mães indicaram, mais que as professoras, que seus filhos expressavam mais elogios e carinhos. Isso faz pensar na hipótese 
situacional (Achenback, McConutghy \& Howell, 1987) que sinaliza que ambientes distintos possibilitam a expressão de comportamentos diferenciados. Portanto, é possível hipotetizar que o ambiente familiar seja mais facilitador da expressão de afetividade, ao passo que o ambiente escolar proporcione mais facilidade para a criança se relacionar com outras crianças, por exemplo. Uma explicação alternativa deve considerar que mães e professoras discriminam comportamentos das crianças segundo a frequência e a qualidade de contato que têm com aquelas. Ou seja, as mães, por terem um contato mais íntimo com os filhos, podem identificar nestes, com mais facilidade que as professoras, a expressão de sentimentos positivos. Já as professoras, por terem um contato diário com muitas crianças, podem indicar mais interações de brincadeiras infantis que as mães.

De todo modo, os dados do estudo concordam em parte com outras pesquisas (Bolsoni-Silva et al. 2006; Feitosa, 2003) que compararam avaliações de mães e de professoras. Os resultados sinalizam para a necessidade de ter diferentes informantes, em diferentes contextos, na avaliação comportamental infantil. Ao mesmo tempo, é importante que futuras pesquisas investiguem variáveis proximais, tais como as práticas educativas parentais, que possam estar relacionadas à ocorrência de problemas de comportamento e ao desenvolvimento de habilidades sociais.

Além disso, as habilidades sociais e as dificuldades comportamentais - descritas anteriormente - poderiam ser trabalhadas em programas de intervenção com as crianças ou de forma indireta com pais e professores. Assim, por exemplo, poderiam se desenvolver, com os pais e com os professores, práticas educativas que ajudassem as crianças a aprender as habilidades sociais requeridas na assertividade, isto é, habilidades que envolvem contextos com risco de uma reação indesejada do interlocutor (Del Prette \& Del Prette, 2005), como ocorre no caso de negociar interesses conflitantes. Nesse sentido, pais e professores poderiam ser orientados a ensinar as crianças a controlar a ansiedade, a expressar de forma apropriada seus sentimentos, desejos e opiniões, bem como superar a passividade e controlar a agressividade. Como consequência, as crianças que são 
frequentemente rotuladas, por apresentarem indicativos de problemas de comportamento, poderiam desenvolver suas potencialidades a partir de seu repertório de habilidades sociais infantis por meio de intervenção com pais e professores.

\section{Conclusão}

O presente estudo teve limitações, dentre as quais podemos destacar que as crianças foram avaliadas a partir dos relatos das mães e das professoras. Deste modo, seria importante que estudos futuros coletassem dados por meio da observação natural ou experimental dos comportamentos investigados na pesquisa. Somado a isso, a maioria das crianças que compunham a amostra era de meninos. Como a literatura indica que os meninos apresentam, com mais frequência que as meninas, dificuldades comportamentais, especialmente externalizantes, seria interessante que futuras pesquisas equilibrassem a amostra em relação ao gênero das crianças. Apesar das limitações, a pesquisa procurou avaliar não apenas os problemas de comportamento das crianças com indicativos clínicos, mas também investigar seu repertório comportamental socialmente habilidoso em dois ambientes distintos: na família e na escola.

\section{Referências bibliográficas}

ACHENBACH, T. M.; McCONAUGHY, S. H.; HOWELL, C. T. Child/adolescent behavioral and emotional problems: implications of cross-informant correlations for situational specificity. Psychological Bulletin, v.101, p.213-32, 1987.

BOLSONI-SILVA, A. T. Habilidades sociais educativas, variáveis contextuais e problemas de comportamento: comparando pais e mães de pré-escolares. Dissertação (doutorado). Curso de Pós-Graduação em Ciências, Faculdade de Filosofia, Ciências e Letras de Ribeirão Preto, Universidade de São Paulo, Ribeirão Preto, 2003. 
; DEL PRETTE, A. Problemas de comportamento: um panorama da área. Revista Brasileira de Terapia Comportamental e Cognitiva, v.5, n.2, p.91-103, 2003.

; MARTURANO, E. M. A qualidade da interação pais e filhos e a sua relação com problemas de comportamentos de pré-escolares. In: BANDEIRA, M.; DEL PRETTE, Z. A. P.; DEL PRETTE, A. (Orgs.). Estudos sobre habilidades sociais e relacionamento interpessoal. São Paulo: Casa do Psicólogo, 2006, p.89-104.

; MARTURANO, E. M.; LOUREIRO, S. R. Roteiro de entrevista de Habilidades Sociais Educativas Parentais RE-HSE-P. In: WEBER, L. D. (Org.). Pesquisando a família: instrumentos para coleta e análise de dados. Curitiba: Juruá, 2009, p.250-7.

Estudos de confiabilidade e validade do Questionário de Respostas Socialmente Habilidosas Versão para Pais-QRSH-Pais. Psicologia: reflexão e crítica. (no prelo).

et al. Habilidades sociais e problemas de comportamento de pré-escolares: comparando avaliações de mães e de professores. Psicologia: reflexão e crítica, v.19, n.3, p.460-9, 2006.

BRIOSO, D.; SARRIÀ, E. Distúrbios de comportamento. In: COLL, C.; PALÁCIOS, J.; MARCHESI, A. (Orgs.). Desenvolvimento psicológico e educação: necessidades educativas especiais e aprendizagem escolar. Porto Alegre: Artes Médicas, v.3, 1995, p.157-68.

CABALLO, V. E. O Treinamento em Habilidades Sociais. In: CABALLO, V. E. (Org.). Manual de técnicas de terapia e modificação do comportamento. São Paulo: Santos, 1996, p.361-98.

CALDARELLA, P.; MERRELL, K. W. Common dimensions of social skills of children and adolescents: a taxonomy of positive behaviors. School Psychology Review, v.26, n.2, p.264-78, 1997.

CAMPBELL, S. B. Behavior problems in preschool children: a review of recent research. Journal Child Psychology and Psychiatry, v.36, n.1, p.113-49, 1995.

CASTRO, R. E. F.; MELO, M. H. da S.; SILVARES, E. F. de M. O julgamento de pares de crianças com dificuldades interativas após um modelo ampliado de intervenção. Psicologia: reflexão e crítica, v.16, n.2, p.309-18, 2003.

DEL PRETTE, Z. A. P.; DEL PRETTE, A. Psicologia das habilidades sociais: terapia e educação. 2. ed. Petrópolis: Vozes, 2001. 
Transtornos psicológicos e habilidades sociais. In: GUILHARDI, H. J. et al. (Orgs.). Sobre comportamento e cognição: contribuições para a construção da teoria do comportamento. 1. ed. Santo André: Esetec, 2002, 10v., p.377-86.

Psicologia das habilidades sociais na infância: teoria e prática. Petrópolis: Vozes, 2005.

Avaliação muldimodal de habilidades sociais em crianças: procedimentos, instrumentos e indicadores. In: BANDEIRA, M.; DEL PRETTE, Z. A. P.; DEL PRETTE, A. (Orgs.). Estudos sobre habilidades sociais e relacionamento interpessoal. São Paulo: Casa do Psicólogo, 2006, p.47-68.

DESSEN, M. A.; ABREU, S.; NETO, N. A. Questões de família e desenvolvimento e a prática de pesquisa. Psicologia: teoria e pesquisa, v.16, n.3, 2000.

DE SALVO, C. G.; MAZZAROTTO, I. H. K.; LÖHR, S. S. Promoção de habilidades sociais em pré-escolares. Revista Brasileira de Crescimento e Desenvolvimento Humano, v.15, n.1, p.46-55, 2005.

FALCONE, E. Habilidades sociais: para além da assertividade. In: Sobre comportamento e cognição. Santo André: Esetec, 2000, p.202-12. FEITOSA, F. B. Relação família-escola: como pais e professores avaliam e reagem ao repertório social de crianças com e sem dificuldades de aprendizagem. Dissertação (mestrado). Programa de PósGraduação em Educação Especial, Universidade Federal de São Carlos, São Carlos, 2003. 60f.

GRAMINHA, S. S.V. A escala comportamental infantil de Rutter A2: estudos de adaptação e fidedignidade. Estudos de Psicologia, v.11, p.34-42, 1994.

KAISER, A. P.; HESTER, P. P. Prevention of conduct disorder through early intervention: a social-communicative perspective. Behavior Disorders, v.22, n.3, p.117-30, 1997.

KUMPULANEIN, K. et al. Children's behavioral /emotional problems: a comparison of parents' and teachers' reports for elementary school-aged children. European Child E Adolescent Psychiatry, v.8, p.41-7, 1999.

LOPES; E. J.; LOPES, R. F. F.; LOBATO, G. R. Algumas considerações sobre o uso do diagnóstico classificatório nas abordagens comportamental, cognitiva e sistêmica. Psicologia em Estudo, v.11, n.1, p.45-54, 2006. 
MARCHESI, A.; MARTIN, E. Da terminologia do distúrbio às necessidades educacionais especiais. IN: COLL, C.; PALÁCIOS, J.; MARCHESI, A. (Orgs.). Desenvolvimento psicológico e educação: necessidades educativas especiais e aprendizagem escolar. Porto Alegre: Artes Médicas, 1995, v.10, cap.8, p.7-23.

PAVARIANO, M. G.; DEL PRETTE, A.; DEL PRETTE, Z. A. P. Agressividade e empatia na infância: um estudo correlacional com pré-escolares. Interação em Psicologia, v.9, n.2, p.215-25, 2005.

RUFFALLO, S. L.; ELLIOTT, S. N. Teachers' and parents' ratings of children's social skills: a closer look at crossinformant agreements through an item analysis protocol. The School Psychology Review, v.26, p.489-501, 1997.

SATAKE, H. et al. Agreement between parents and teachers on behavioral/emotional problems in japanese school children using the Child Behavior Checklist. Child Psychatry and Human Development, v.34, p.111-26, 2003.

SILVA, A. T. B. Problemas de comportamento e comportamentos socialmente adequados: sua relação com habilidades sociais educativas de pais. Dissertação (Mestrado). Curso de Pós-Graduação em Educação Especial, Universidade Federal de São, São Carlos, 2000.

SILVARES, E. F. de. M. Invertendo o caminho tradicional do atendimento psicológico numa clínica-escola brasileira. Estudos de Psicologia, v.5, n.1, p.149-80, 2000.

SANTOS, P. L. dos. Riscos e recursos em crianças com alto e baixo rendimento acadêmico: um estudo comparativo. Tese (Doutorado). Faculdade de Filosofia, Ciências e Letras de Ribeirão Preto, Universidade de São Paulo, Ribeirão Preto, 2002. 


\section{1 \\ PROMOVENDO HABILIDADES \\ EDUCATIVAS PARENTAIS: CARACTERIZANDO A ATUAÇÃO DO TERAPEUTA ${ }^{1}$}

Fabiane Ferraz Silveira, Alessandra Turini Bolsoni-Silva ${ }^{2}$ e Sonia Beatriz Meyer ${ }^{3}$

\section{Introdução}

A justificativa para a realização de intervenção com pais, tanto individualmente como em grupo, é a de que práticas educativas parentais positivas podem evitar o surgimento e/ou a manutenção de problemas de comportamento, já as negativas podem aumentar a probabilidade de ocorrência de tais problemas (Patterson, Reid \& Dishion, 2002). Para Gomide (2006), as práticas positivas incluem a monitoria positiva, que envolve expressão de afeto e estabelecimento de limites, e a promoção do comportamento moral. Por outro lado, as práticas educativas negativas envolvem abuso físico e psicológico, negligência, ausência de atenção e de afeto, além da monitoria negativa, que implica em excesso de instruções, independentemente de seu cumprimento.

1 O presente trabalho é parte da dissertação de mestrado da primeira autora, sob orientação da segunda e terceira autoras. Apoio financeiro por meio de Bolsa de Mestrado concedido pela Fapesp (processo n ${ }^{\circ}$ 07/52808).

2 Programa de Pós-Graduação em Psicologia do Desenvolvimento e Aprendizagem da Unesp - Bauru.

3 Programa de Pós-Graduação em Psicologia Clínica da Universidade de São Paulo, USP - São Paulo. 
Acredita-se que o campo teórico-prático do Treinamento em Habilidades Sociais (THS) possa contribuir para o entendimento das práticas educativas parentais. Por habilidades sociais entende-se um conjunto de repertórios comportamentais aprendidos, sobretudo operantes, que maximizam a obtenção de reforçadores positivos e negativos (Bolsoni-Silva, 2002) nas interações sociais (Del Prette \& Del Prette, 2001). As habilidades sociais dos pais aplicáveis às práticas educativas são definidas como habilidades sociais educativas parentais (Bolsoni-Silva, 2008).

De acordo com Bolsoni-Silva et al (2010), os programas de intervenção psicoeducacionais com pais, ainda que contenham características diversas quanto aos objetivos e procedimentos, mostram-se efetivos, promovendo o aumento de interações positivas entre pais e filhos, o fortalecimento de habilidades de manejo comportamental, melhoras significativas nas habilidades parentais de lidar com conflitos, a comunicação e a cooperação, a redução de problemas de comportamento e também a generalização das habilidades aprendidas.

A despeito da eficácia de várias modalidades de intervenção para pais ter sido divulgada na literatura, considera-se que o conhecimento até então produzido não seja suficiente para esclarecer quais variáveis, especialmente comportamentos do terapeuta, são responsáveis pelas mudanças observadas.

Silveira (2009) teceu considerações sobre as sistematizações de comportamentos do terapeuta em intervenções com pais desenvolvidas por Webster-Stratton \& Herbert (1993) e Bolsoni, Carrara \& Marturano (2008). A primeira proposta (Webster-Stratton \& Herbert, 1993) consiste de um modelo colaborativo de intervenção, mediante os comportamentos do terapeuta, de investigação e valorização das opiniões dos participantes, esclarecimentos, sumarização e sugestão de mudanças. Já a iniciativa de Bolsoni, Carrara \& Marturano (2008) ampliou o número de categorias de um sistema já existente (Tourinho, Garcia \& Souza, 2003) ao incluir: solicitação de modelos, opiniões e informações sobre a tarefa de casa; avaliação do cliente sobre verbalizações do terapeuta e ava- 
liação da sessão; feedback de aprovação e desaprovação; sugestão; estruturação da sessão; tomada de palavra; sumarização, acolhimento e generalização.

No escopo das discussões expostas por Bolsoni, Carrara e Marturano (2008) está a observação dos comportamentos do terapeuta, definidos para a psicoterapia individual (Tourinho et al., 2003), juntamente com as novas categorias elaboradas, na intervenção com a população específica de pais, nas diferentes etapas das sessões de grupo: investigação da tarefa de casa, exposição teórica dialogada e treino de habilidades. Considera-se, porém, que ambas as propostas de sistematizações de comportamentos do terapeuta em programas com pais, apesar de representativos em termos de análises prescritivas e descritivas, prescindem de detalhamento com relação à metodologia utilizada (Silveira, 2009), o que restringe a amplitude das replicações.

Zamignani (2007) realizou uma análise minuciosa do sistema de categorização Therapy Process Code (Chamberlain et al., 1984), que possibilita o exame dos comportamentos do terapeuta e do cliente em intervenções com famílias. São definidos oito comportamentos do terapeuta (buscar informações, estruturar, apoiar, discordar, interpretar/reformular, facilitar e falar) e nove categorias que abordam a resistência do cliente (confrontar/desafiar/discordar, culpar/ queixar-se, defender a si/outros, desviar, responder, desqualificar, não resistente e não resposta). Tal sistematização possui considerável consistência metodológica, principalmente por dispor categorias mutuamente exclusivas, coerentes com os critérios definidores, utilizadas em um número significativo de pesquisas. Contudo, concentram-se em eventos de restrita transposição para estudos na Análise do Comportamento ou enfatizam o estudo da resistência, restringindo o uso para demais questões de pesquisa (Zamignani, 2007).

Em suma, constatam-se indicativos na literatura de posicionamentos convergentes quanto às habilidades do terapeuta, independente da clientela atendida, como, por exemplo, investigação, esclarecimento/informação, interpretação, ensino/conselho e aprovação/ 
valorização (Chamberlain et al., 1984; Tourinho et al., 2003; Zamignani, 2007; Webster-Stratton \& Herbert, 1993).

Supõe-se que um diferencial dos comportamentos do terapeuta em intervenções com pais, sobretudo no que se refere a atendimento em grupo, é exemplificado pela categoria Solicitação de modelos (Bolsoni-Silva et al., 2008).

Com relação ao comportamento do cliente em intervenções com pais, observa-se a prevalência de "concordância", "relato", "estabelece relações" e "resistência/oposição" (Chamberlain et al., 1984; Patterson \& Forgatch, 1985; Silveira, 2009).

A sistematização dos comportamentos do terapeuta e de clientes em intervenções com pais implica no avanço da descrição das variáveis presentes no contexto clínico. Não obstante, suscita novos questionamentos sobre as dimensões dos eventos comportamentais observados, sobretudo frequência e duração, bem como a identificação de relações de funcionalidade, isto é, a identificação de quais comportamentos dos clientes, que somados a outras variáveis, devem controlar o desempenho do terapeuta e vice-versa.

A indicação dos controles e efeitos dos comportamentos do terapeuta em intervenções de sucesso contribui para o acúmulo de evidências sobre os fatores responsáveis pelo processo de mudança comportamental. A descrição das habilidades do terapeuta em atendimentos com pais favorece a identificação de quais repertórios são necessários para o manejo desse tipo de intervenção, os quais auxiliarão no aperfeiçoamento dos profissionais em exercício.

Face ao exposto, pretende-se neste estudo analisar uma intervenção bem sucedida com mães, sob o foco da descrição dos comportamentos do terapeuta. 


\section{Método}

\section{Participantes}

Na intervenção, participaram duas mães e uma avó, ${ }^{4}$ aqui denominadas $\mathrm{P} 1, \mathrm{P} 2$ e P3, e uma terapeuta comportamental com três anos de experiência em intervenções com pais. A participante P1 contava 31 anos, tinha o Ensino Fundamental incompleto, era casada, do lar, com renda familiar na faixa de um salário mínimo. P2 contava 39 anos, tinha o Ensino Fundamental incompleto, era casada, do lar, com renda familiar na faixa de dois salários mínimos. A participante P3 tinha 51 anos, Ensino Fundamental incompleto, era divorciada, do lar, com renda familiar na faixa de um salário mínimo.

\section{Procedimento de coleta e análise de dados}

Foram filmadas 13 de 14 sessões de uma intervenção em grupo com mães. A intervenção foi desenvolvida durante a vigência do projeto "Avaliação dos efeitos de um programa de intervenção com pais e mães que apresentam dificuldades de interação social com seus filhos", cujos resultados estão parcialmente publicados em BolsoniSilva, Silveira \& Ribeiro (2008) e sucintamente descritos no tópico a seguir. As filmagens das sessões para a realização desta pesquisa foram cedidas pela coordenadora do projeto.

Foram designadas, por meio de sorteio, as sessões 5, 6, 10, $13 \mathrm{e}$ 14 , totalizando dez horas de filmagens. O registro das categorias do terapeuta e clientes foi realizado por meio do software The Observer ${ }^{\circledR}$ XT 7.0 e a partir do Sistema Multidimensional de Categorização de Comportamentos do Terapeuta e Cliente (Zamignani, 2007) e das categorias do terapeuta e cliente elaboradas por Silveira (2009) para intervenções com pais. O sistema desenvolvido por Zamignani foi

4 A participante P3 não era a responsável legal por sua neta, mas assumiu seus cuidados em tempo integral. 
escolhido devido à sua compatibilidade na investigação das questões de pesquisa ora formuladas e por apresentar indícios empíricos de validade e fidedignidade. O Sistema Multidimensional de Categorização apresenta as categorias do terapeuta: "solicitação de relato”, "facilitação", "empatia”, "informação", "solicitação de reflexão”, "recomendação”, "interpretação”, "aprovação", "reprovação” e "outras". Em relação aos comportamentos do cliente, Zamignani (2007) definiu as categorias "solicitação", "relato", "relato de melhora ou progresso terapêutico", "formulação de metas", "estabelecimento de relações", "concordância”, "oposição” e "outras”.

Análises de correlação entre as categorias do terapeuta e cliente (Teste Spearman's rho) foram realizadas por meio do pacote estatístico SPSS (Versão 14.0). A análise de correlação foi conduzida a partir das frequências totais das categorias do terapeuta, sem distinção para qual cliente foi apresentada, e também por meio das frequências totais das categorias do cliente, sem diferenciação dos participantes.

\section{Procedimentos da intervenção analisada}

Para a avaliação do programa de intervenção foram utilizadas comparações entre avaliações controle/linha de base, pré-intervenção e pós-intervenção. Na avaliação de pré-intervenção foram realizadas entrevistas individuais e aplicação dos instrumentos CBCL (Bordin, Mari \& Caieiro, 1995), Inventário de Habilidades Sociais (IHS) (Del Prette \& Del Prette, 2001b) e Roteiro de Entrevista de Habilidades Sociais Educativas Parentais (BolsoniSilva, 2008). Já no controle e pós-intervenção, somente foram aplicados os instrumentos.

Os dados da avaliação pré-intervenção foram organizados em estudos de caso, no qual constavam a conceituação comportamental em relação às queixas apresentadas e os objetivos individuais a serem atingidos com cada cliente. A participante P1 descreveu seu filho de seis anos como tranquilo e carinhoso, porém, quando presencia a irmã desobedecer, logo começa a imitar seus comportamentos. 


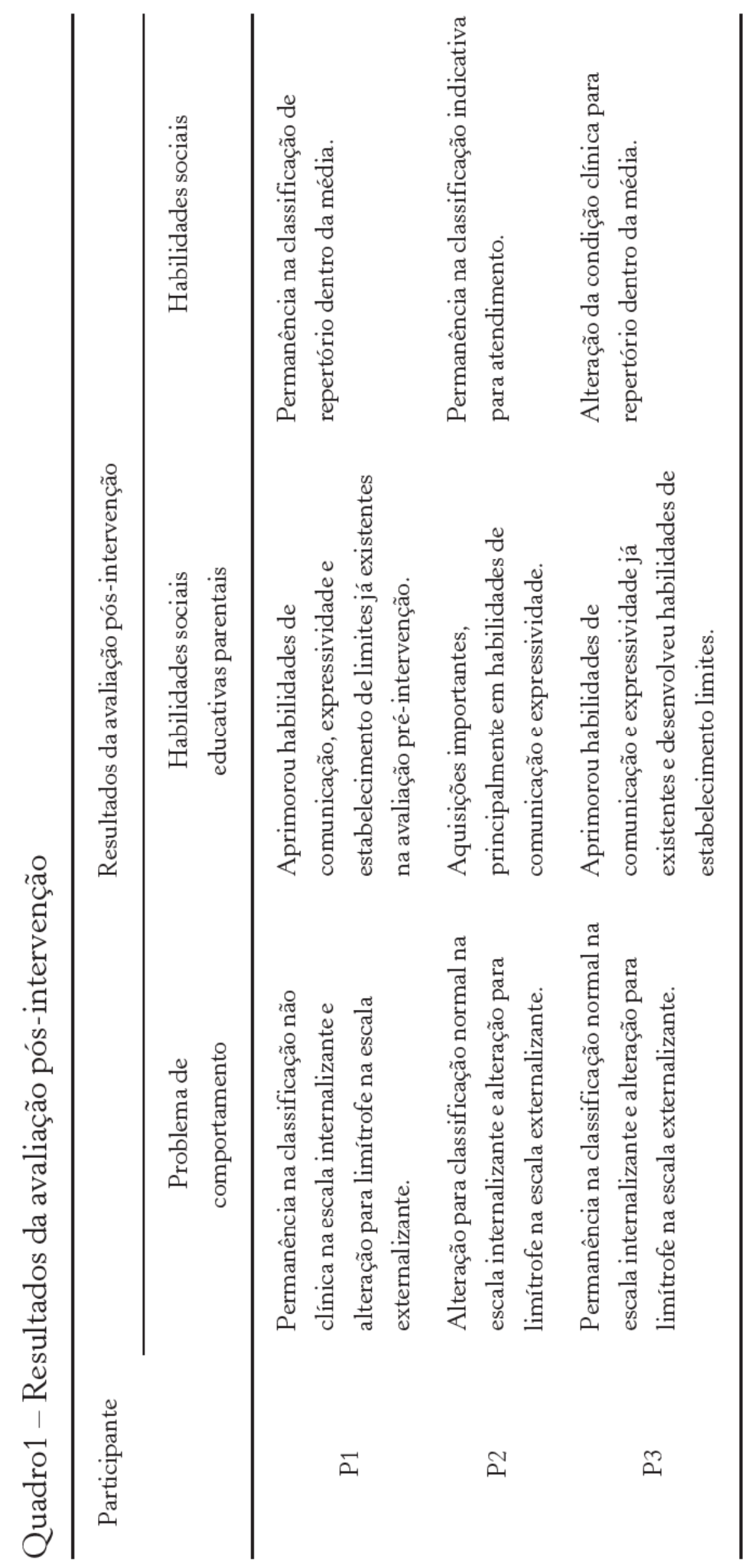


A cliente relatou que nessas situações consegue controlar os filhos por meio de gritos e ameaças. Foram estabelecidos como objetivos para essa cliente a ampliação das habilidades de comunicação, de expressão de sentimentos e enfrentamento e de estabelecer limites. P2 apresentou como queixa o fato de o filho de cinco anos ser desobediente e agressivo com os familiares, colegas da creche e professores. Foram propostos os seguintes objetivos para essa cliente: desenvolver repertórios de comunicação e expressividade, aumentar a frequência de interações positivas e agradáveis com o filho e desenvolver repertório de estabelecer limites.

A participante $\mathrm{P} 3$ apresentou como queixas em relação ao comportamento da neta de cinco anos, agressividade dirigida às crianças de sua convivência (irmãos, vizinhos e colegas da creche) e desobediência. Relatou que ora a criança lhe obedece ora não, pois é muito "autoritária". Foram estabelecidos como objetivos aprimorar o repertório de expressividade e comunicação e desenvolver repertório de estabelecer limites.

A seguir, são apresentados os resultados obtidos com cada participante.

A intervenção utilizou como referencial teórico a Análise do Comportamento e do instrumental derivada desta, quais sejam, o Treinamento em Habilidades Sociais (THS), o modelo colaborativo de intervenção (Webster-Stratton \& Herbert, 1993) e o modelo construcional de intervenção de Goldiamond (2002). O enfoque do modelo construcional está na ampliação do repertório comportamental do cliente, a partir do desenvolvimento ou fortalecimento de comportamentos alternativos com funções equivalentes aos padrões que têm trazido problemas (idem, ibidem).

Nas sessões analisadas foram discutidas a expressão de opiniões (sessão 5), o comportamento habilidoso (sessão 6), o estabelecimento de limites: consistência na educação (sessão 10), estabelecimento de regras e negociação (sessão 13) e tema livre: sexualidade infantil (sessão 14).

As sessões foram estruturadas, de forma geral, em: tarefa de casa: investigação da tarefa de casa da sessão anterior; exposição teórica 
dialogada: realização de uma exposição dialogada a respeito do tema da sessão utilizando uma cartilha informativa (Bolsoni-Silva, Silveira \& Marturano, 2006); treino de repertórios relacionados às temáticas por meio de atividades e principalmente role playing; distribuição da tarefa de casa (referente ao comportamento trabalhado em sessão) e avaliação da sessão. Cabe destacar que a realização de avaliação funcional, entendida como instrumento de análise e intervenção que possibilita a investigação de relações entre eventos ambientais e comportamentais (Meyer, 2003), ocorre em todas as etapas anteriormente descritas.

\section{Resultados e discussão}

Inicia-se esta seção apresentando a distribuição dos percentuais de ocorrência e duração das verbalizações da terapeuta em relação às três clientes, no total das cinco sessões analisadas (Figura 1). Na sequência, a Figura 2 apresenta o percentual de ocorrência das categorias da terapeuta. Já a Figura 3 mostra a frequência das subcategorias da categoria "recomendação" no decorrer das sessões. Os dados da Figura 3 são apresentados por incluírem novas subcategorias identificadas. Por fim, a Tabela 1 expõe a análise de correlação, indicando relações entre comportamentos da terapeuta e dos clientes.

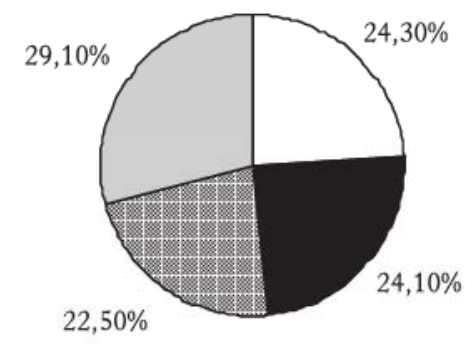

Percentual de ocorrência

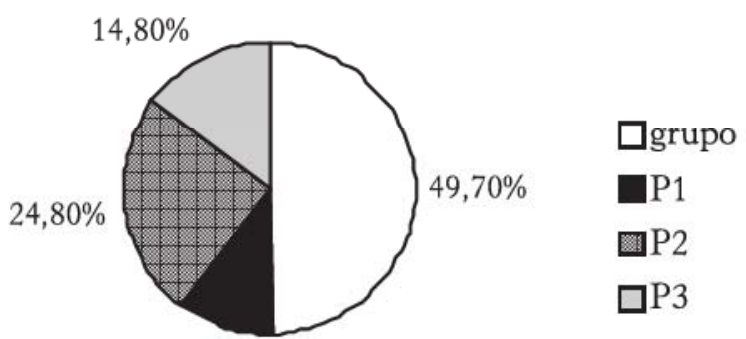

$10,70 \%$

Percentual de duração

Figura 1 - Percentual de ocorrência e duração das verbalizações da terapeuta dirigidas ao grupo e a P1, P2 e P3 no total das sessões analisadas e em relação às verbalizações da mesma participante 
A partir da Figura 1 observa-se que o maior percentual de ocorrência das verbalizações da terapeuta é dirigido à participante $\mathrm{P} 3$, em seguida para o grupo, para P1 e, por fim, para P2. Nota-se também, em relação ao percentual de duração, a prevalência de verbalizações dirigidas ao grupo, seguidas de outras dirigidas a P2, P3 e P1.

As medidas de ocorrência e duração indicam que a terapeuta, no decorrer do processo terapêutico, ao se dirigir ao grupo, apresentou verbalizações mais longas. As intervenções dirigidas a P3 são caracterizadas por verbalizações curtas, porém mais frequentes se comparadas às dirigidas ao restante do grupo. As verbalizações que se referem à $\mathrm{P} 2$ atingem maior duração se comparadas às referentes a P1 e P3, entretanto, são menos frequentes. As intervenções da terapeuta dirigidas à $\mathrm{P} 1$ não se destacaram como mais frequentes ou de longa duração. Presume-se que a terapeuta comportou-se de forma diferenciada no que tange a frequência e duração de suas verbalizações, o que seria esperado, dado os objetivos individualizados a serem alcançados.

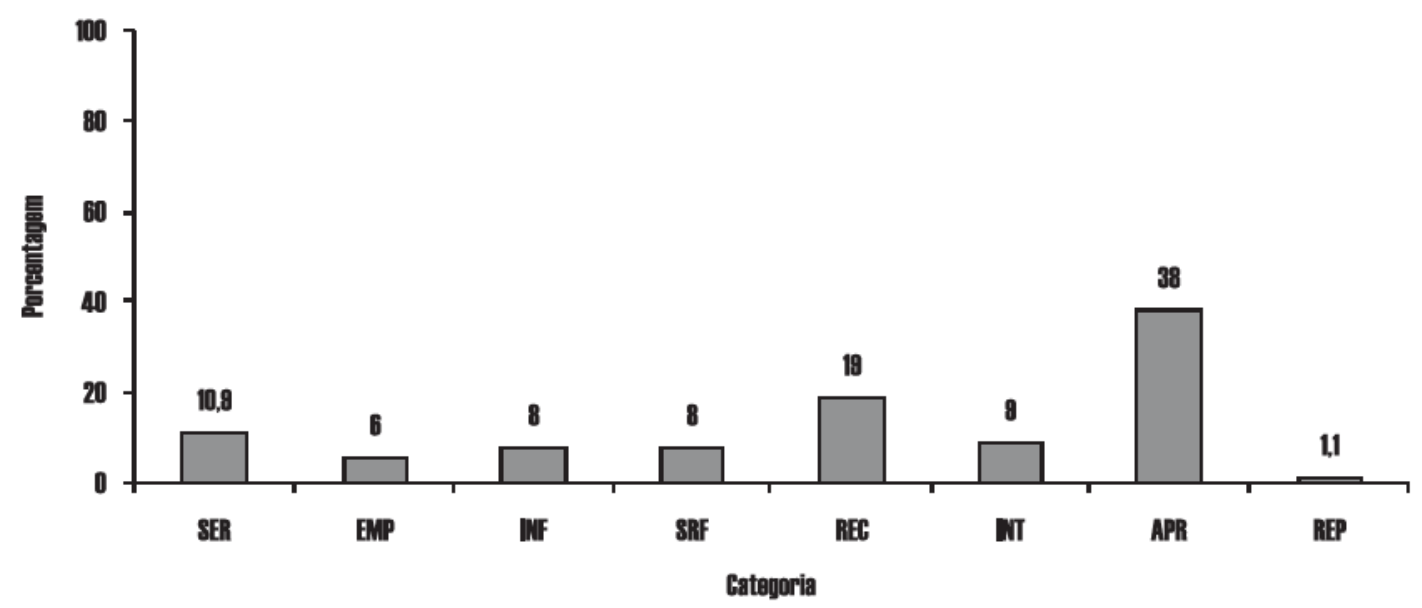

Figura 2 - Percentual de ocorrência das categorias da terapeuta no total das sessões analisadas e em relação às verbalizações da mesma participante

De acordo com a Figura 2, as categorias "aprovação" (APR), "recomendação" (REC) e "solicitação de relato" (SER) correspondem aos maiores percentuais de ocorrência. As categorias "reprovação" (REP) e "empatia" (EMP) correspondem aos menores percentuais de ocorrência no total das cinco sessões analisadas. As categorias "in- 
formação" (INF), "solicitação de reflexão" (SRF) e "interpretação" (INT) atingiram percentuais similares.

A alta frequência da categoria "aprovação" somada à baixa frequência e duração da categoria "reprovação", além de indicar uma preocupação da terapeuta em representar uma audiência não punitiva (Braga \& Vanderberghe, 2006), remete à possível utilização do procedimento de reforçamento diferencial aplicado à propriedade da resposta (Catania, 1999), como forma de enfraquecer ou fortalecer a ocorrência de certos comportamentos. Outros fatores que podem ter determinado a alta ocorrência da categoria aprovação dizem respeito ao modelo colaborativo de intervenção (Webster-Stratton \& Herbert, 1993), que recomenda a valorização das alternativas propostas pelos pais para as dificuldades apresentadas e do modelo construcional de intervenção (Goldiamond, 2002), que pressupõe a ampliação do repertório a partir do fortalecimento das reservas comportamentais (Kanfer \& Saslow, 1976), o que pode ter levado a terapeuta a sinalizar tais ocorrências durante todo o processo.

A ocorrência expressiva de recomendação pode ser explicada por meio das características do próprio programa de intervenção, isto é, dos procedimentos e temáticas planejados para cada sessão. Para cada uma das 14 sessões, o planejamento explicitava as atividades a serem desenvolvidas e as habilidades sociais educativas a serem trabalhadas, sendo que as unidades comportamentais representavam prérequisitos para habilidades a serem abordadas em sessões posteriores.

De acordo com Meyer (2004), o excesso de orientação durante o processo terapêutico dificulta a aquisição de repertório, por parte do cliente, que o conduzisse ao autocontrole e à autonomia. Frente a essas considerações e a todos os achados teóricos e experimentais consistentes, referentes ao comportamento governado verbalmente (Catania, 1999), cuja discussão não cabe ao escopo deste trabalho, temse por hipótese, a partir da Figura 2, que ambos os procedimentos, orientação ("recomendação") e modelagem por aproximações sucessivas - devido à alta frequência de "aprovação" e à baixa frequência de "reprovação" - foram empregados com igual ou similar frequência, igualando, portanto, as vantagens e desvantagens de cada um. 
A alta frequência da categoria "solicitação de relato" no decorrer do processo terapêutico resulta em posição discordante ao estudo de Harwood \& Eyberg (2004), que a consideram como variável preditiva de abandono em terapias familiares. Entretanto, tal como salientaram Harwood e Eyberg (idem), o prejuízo para o processo terapêutico estaria na alta frequência de questões fechadas em relação às abertas, diferenciação não avaliada neste estudo. A alta frequência de "solicitação de relato" pôde gerar esclarecimentos a respeito das contingências em operação na vida das clientes e a exposição de experiências difíceis ou de sucesso entre os participantes do grupo.

A Figura 3 apresenta a frequência das subcategorias da categoria "recomendação", incluindo "solicitação de aprovação", "solicitação de reprovação" e "solicitação de recomendação".

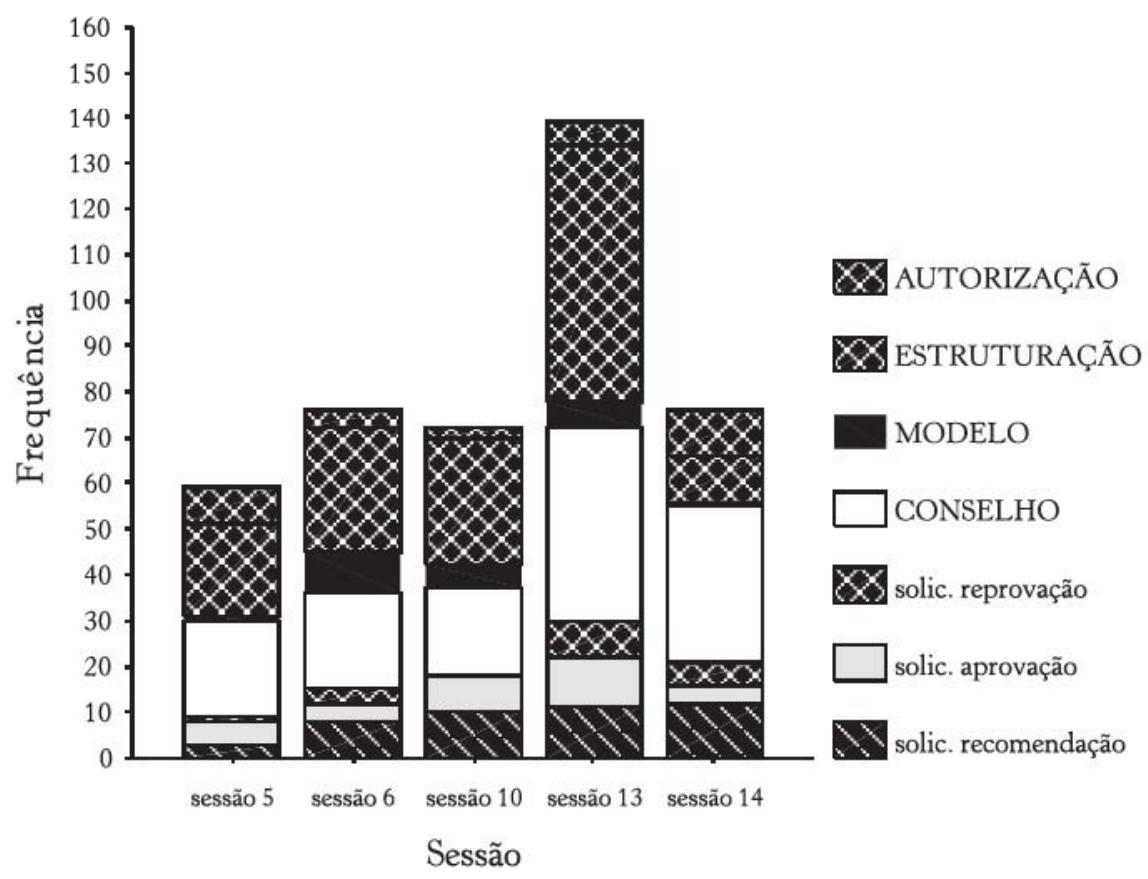

Figura 3-Frequência de "recomendação" e de suas subcategorias no decorrer das sessões

A partir da Figura 3 observa-se que a frequência da categoria "recomendação" se mantém constante, com exceção da sessão 13, em que há um aumento. A décima terceira sessão corresponde à penúltima sessão do processo terapêutico, o que justifica a alta frequência de "recomendação", dada a ênfase da terapeuta em garantir a 
apresentação de orientações finais e a restrição do tempo para procedimento de modelagem.

As subcategorias "solicitação de recomendação", "solicitação de aprovação" e "solicitação de reprovação" referem-se às novas subcategorias elaboradas no presente estudo. Já o restante faz parte do sistema proposto por Zamignani (2007). Com relação à "solicitação de aprovação" e à "solicitação de reprovação", notam-se ocorrências discretas em todas as sessões, com ligeiro aumento na sessão 13. Verifica-se um aumento na frequência de "solicitação de recomendação" no decorrer das sessões, sinalizando a iniciativa da terapeuta de gradualmente compartilhar com os clientes a responsabilidade por fornecer instruções e modelos a serem seguidos.

Constata-se a prevalência de "estruturação de atividade" e "conselho". A subcategoria "estruturação de atividade" consiste em solicitação da participação dos clientes em atividades técnicas durante a sessão, tendo sido incluída em outras sistematizações (Bolsoni-Silva et al., 2008; Chamberlain et al., 1994), salientando sua relevância para o trabalho com pais. A subcategoria conselho consiste de verbalizações que especificam comportamentos a serem emitidos pelo cliente dentro ou fora da sessão. A alta ocorrência de Conselho ao final do processo terapêutico possivelmente traduz uma retomada de orientações anteriormente apresentadas ou a apresentação de novas instruções essenciais para as alterações pretendidas. A seguir são apresentadas as análises de correlação (Tabela 1).

$\mathrm{Na}$ Tabela 1 observam-se correlações positivas significativas entre categorias do terapeuta e categorias do cliente, como "informação" e "estabelece relações", "interpretação" e "concordância”. A categoria "informação" chama a atenção por suas contribuições para o processo terapêutico, pois quanto maior sua probabilidade, maior será a probabilidade de apresentação de "estabelece relações" por parte do cliente. A importância de "estabelece relações" para o processo terapêutico encontra respaldo no posicionamento de Skinner (1978), para quem a identificação e descrição das variáveis determinantes auxiliam no autoconhecimento e autocontrole. 
Tabela 1 - Análises de correlação (Teste Spearman's rho) entre categorias do terapeuta e categorias do cliente

Correlação positiva

\begin{tabular}{ll}
\hline Categoria do terapeuta & Categoria do cliente \\
Solicitação de relato & Relato \\
Empatia & Solicitação \\
Informação & Estabelece relações \\
Interpretação & Concordância \\
Aprovação & Melhora \\
\hline
\end{tabular}

Correlação negativa
Informação
Formula meta

* nível de significância 0,01

A correlação positiva entre "interpretação" e "concordância" vem corroborar outros estudos que atestaram a importância dessa categoria para o processo terapêutico (Patterson \& Chamberlain, 2004). As correlações positivas entre "empatia" e "solicitação" indicam que os pedidos de esclarecimentos ou apresentação de demanda dos clientes ("solicitação") estão vinculados a demonstrações de aceitação, compreensão e afetividade por parte da terapeuta ("empatia").

Observam-se correlações negativas significativas entre "formula meta" e "informação", indicando a importância de uma frequência ótima de "informação" que seja suficiente para favorecer as ocorrências de "estabelece relações", mas não prejudique as ocorrências de "Formula meta".

Diferentes estudos, mediante análises correlacionais, formalizaram conclusões sobre associações entre comportamentos do terapeuta e resultados satisfatórios ou insatisfatórios da terapia (Keijsers et al., 1995) ou relações entre comportamentos dos participantes e abandono da intervenção (Harwood \& Eyberg, 2004). Nesse sentido, as análises de correlação aqui expostas representam um diferencial dos estudos da área na medida em que produzem inferências sobre rela- 
ções de funcionalidade entre comportamentos do terapeuta e do cliente com maior sustentação empírica.

\section{Conclusão}

Na intervenção avaliada, observou-se uma distribuição equitativa da frequência das verbalizações da terapeuta em relação aos participantes, entretanto, a duração despendida alcança proporções diferenciadas, com destaque para o coletivo. Observou-se alta frequência de recomendação e aprovação e ínfima ocorrência de reprovação, o que implica na hipótese da introdução de procedimentos de modelagem do comportamento verbal do cliente e apresentação de regras.

Um diferencial atribuído à população atendida diz respeito às categorias do terapeuta "solicitação de aprovação", "reprovação" e "recomendação". A impossibilidade de modelagem direta das habilidades sociais educativas parentais no contexto da sessão pode explicar a ocorrência de tais comportamentos como forma de fortalecer repertórios (aprovação, reprovação e recomendação) de especial utilidade no manejo de comportamentos dos filhos.

Análises correlacionais indicaram relações positivas e negativas entre comportamentos da terapeuta e dos clientes. Dentre os resultados significativos destacam-se algumas relações integralmente favoráveis ao processo terapêutico, como "informação" e "estabelecimento de relações" e "interpretação" e "concordância", diferentemente de correlação negativa entre "informação" e "formula metas".

Nos programas de intervenção destinados aos pais o terapeuta pode se deparar com queixas múltiplas referentes ao comportamento dos filhos, membros familiares ou variáveis contextuais que incidem sobre a família. Comumente também são descritas histórias de vida pródigas de insucesso no manejo de comportamentos e estabelecimento de interações positivas entre pais e filhos. Os comportamentos do terapeuta ora mencionados indicam possibilidades de uma atuação associada à produção de resultados de sucesso. Salienta-se, por fim, a importância dos referenciais de intervenção consolida- 
dos na literatura, os quais influenciaram fortemente o desempenho da terapeuta ao criar condições para uma interação colaborativa, com ênfase nas reservas comportamentais e ampliação de repertórios.

\section{Referências bibliográficas}

BOLSONI-SILVA, A. T. Roteiro de Entrevista de Habilidades Sociais Educativas Parentais (RE-HSE-P): categorias e testagem preliminares. In: WEBER L. (Org.). Família e desenvolvimento. Curitiba: Juruá, 2008, p.145-58.

Habilidades sociais: breve análise da teoria e da prática à luz da Análise do Comportamento. Interação, v.6, p.233-42, 2002.

; CARRARA, M.; MARTURANO, E. M. Intervenção em grupo para pais: o que atentar quanto à intervenção e habilidades terapêuticas. In: CAVALCANTE, M. R(Org.). Análise do comportamento: avaliação e intervenção. São Paulo: Roca, 2008, p.102-35.

; SILVEIRA, F. F.; MARTURANO, E. M. Cartilha informativa: orientação para pais e mães. São Carlos: Suprema Editora, 2006. ; VILLAS-BOAS, A. C. V.; ROMERA, V. B.; SILVEIRA, F. F. Caracterização de programas de intervenção com crianças e/ ou adolescentes. Arquivos Brasileiros de Psicologia, v.62, p.10415, 2010.

BORDIN, I. A. S.; MARI, J. J.; CAEIRO, M. F. Validação da versão brasileira do Child Behavior Checklist (CBCL). Inventário de comportamentos da infância e da adolescência: dados preliminares. $R e-$ vista ABP-APAL, v.17, p.50-66, 1995.

BRAGA, G. L. B.; VANDERBERGUE, L. V. Abrangência e função da relação terapêutica na terapia comportamental. Estudos de Psicologia Campinas, v.23, n.3, p.307-14, 2006.

CATANIA, A. C. Aprendizagem: comportamento, linguagem, cognição. Porto Alegre: Artmed, 1999.

DEL PRETTE, Z. A. P.; DEL PRETTE, A. Psicologia das relações interpessoais: vivências para o trabalho em grupo. Petrópolis: Vozes, 2001a.

Inventário de Habilidades Sociais (IHS-Del-Prette).

São Paulo: Casa do Psicólogo, 2001b. 
GOLDIAMOND, I. Toward a constructional approach to social problems: ethical and constitutional issues raised by applied behavioral analysis. Behavior and Social Issues; v.11, p.108-97, 2002.

GOMIDE, P. I. C. Inventário de estilos parentais. Modelo Teórico: manual de aplicação, apuração e interpretação. Petrópolis: Vozes, 2006.

HARWOOD, M. D.; EYBERG, G. Therapist verbal behavior in treatment: relation to successful completion of parent-children interaction therapy. Journal of Clinical Child and Adolescent Psychology, v.33, p.601-12, 2004.

KANFER, F. H.; SASLOW, G. An outline for behavior diagnosis. In: MASH, E. J.; TERDAL, L. G. (Eds.). Behavior Therapy Assessment. New York: Springer Publishing Company, 1976.

KEIJSERS, G. P. J. et al. Patienttherapist interaction in the behavioral treatment of panic disorder with agoraphobia. Behavior Modification, v.19, p.491-517, 1995.

MEYER, S. B. Análise de 'solicitação de informação' e 'recomendação' em banco de dados de terapias comportamentais. Tese (Livre-docência). Instituto de Psicologia da Universidade de São Paulo. Universidade de São Paulo, São Paulo, 2009

Regras e autorregras no laboratório e na clínica. In: ABREURODRIGUES; RIBEIRO (Orgs). Análise do comportamento. s. 1.: s. n., 2004, p.212-26.

PATTERSON, G. et al. Observation of client resistance. Behavior Therapy, v.15, p.144-55, 1984.

; REID, J.; DISHION, T. Antisocial boys: comportamento antissocial. Santo André: Esetec, 2002.

SILVEIRA, F. F. Análise da interação terapêutica em uma intervenção de grupo com cuidadoras. Dissertação (Mestrado). Universidade Estadual Paulista, Bauru, 2009.

TOURINHO, E. Z.; GARCIA, M. G.; SOUZA, L. M. Avaliação ampliada de categorias para análise de verbalizações de terapeutas. Projeto de pesquisa. Universidade Federal do Pará, Belém, 2003.

WEBSTER-STRATTON, C.; HERBERT, M. What really happens in parent training? Behavior Modification, v.17, n.4, p.407-56, 1993.

ZAMIGNANI, D. R. O desenvolvimento de um sistema multidimensional para a categorização de comportamentos na interação terapêutica. Dissertação (Doutorado). Universidade de São Paulo, São Paulo, 2007. 



\section{2 \\ A INTERAÇÃO ENTRE PAIS E FILHOS ADOLESCENTES SOB A ÓTICA DA ANÁLISE APLICADA DO COMPORTAMENTO}

Gabriela Mello Sabbag e Alessandra Turini Bolsoni-Silva ${ }^{1}$

\section{Introdução}

As influências sobre o comportamento humano, em geral, são complexas e muitas vezes difíceis de serem detectadas (Skinner, 1998). No caso de um adolescente, há diversas contingências que podem atuar sobre seu comportamento e que estão presentes no relacionamento com seus pais e demais familiares, nas relações entre pares, na escola, na mídia, nas condições socioeconômicas e culturais, entre outras (Gomide, 2003). Dos fatores citados, a relação entre pais e filhos adolescentes foi o tema escolhido para este trabalho.

A perspectiva abordada por este estudo aponta para a importância de aprofundar os conhecimentos sobre a relação entre pais e filhos adolescentes por meio da análise funcional do comportamento (Skinner, 1998), em outras palavras, busca identificar como os comportamentos parentais e filiais se inter-relacionam. Para tanto se utiliza a proposta de Bolsoni-Silva (2003; 2008; 2009), a qual

1 Programa de Pós-Graduação em Psicologia do Desenvolvimento e Aprendizagem, Unesp - Bauru. 
vai ao encontro da análise funcional das interações entre pais e filhos. A autora propõe o estudo das Habilidades Sociais Educativas Parentais, no qual descreve de forma operacional e interativa as ações parentais, habilidosas, ${ }^{2}$ ou não, relacionadas aos comportamentos dos filhos, sejam eles habilidosos ou indicativos de problemas de comportamento, os quais retroagem sobre os comportamentos parentais e vice-versa (idem, ibidem).

A Análise do Comportamento é a ciência que aplica os conceitos e as propostas filosóficas do Behaviorismo Radical ao estudo do comportamento humano (Skinner, 1974). A filosofia behaviorista radical considera o comportamento humano como um conjunto de interações entre o organismo e seu ambiente, determinadas por fatores filogenéticos, ontogenéticos e culturais. A filogênese diz respeito às interações determinadas por herança genética, a ontogênese refere-se às interações determinadas por variáveis presentes na história de aprendizagem do indivíduo e a cultura envolve determinadas práticas sociais. Os três fatores determinantes do comportamento humano estão sob efeito da seleção por consequências (idem, 1981).

Dois campos de estudo e de atuação baseiam-se nas propostas do Behaviorismo Radical: a Análise Experimental do Comportamento e a Análise do Comportamento Aplicada (Carvalho Neto, 2002). A Análise Experimental do Comportamento refere-se à pesquisa que conduz a produção e a validação de dados empíricos em um contexto controlado e artificial para a identificação das relações funcionais que envolvem o comportamento. Já a Análise do Comportamento Aplicada envolve as intervenções elaboradas pelos analistas do comportamento, por meio do planejamento e da avaliação dos resulta-

2 Comportamentos habilidosos emitidos em ambientes sociais são denominados de habilidades sociais (Del Prette\& Del Prette,1999). Tais habilidades são responsáveis pela aprendizagem de novos comportamentos, os quais aumentam a probabilidade de se obter reforçadores que podem favorecer a aprendizagem de outros novos comportamentos relevantes ao repertório do indivíduo (RosalesRuiz, 1997). 
dos obtidos pelos procedimentos adotados, nas mais diversas áreas da psicologia (idem, ibidem).

Para Skinner (1998), o estudo do comportamento envolve a investigação e a descrição das relações funcionais que o envolvem e não somente a busca da causa e do efeito. Para a análise da seleção de comportamentos ontogenéticos deve-se considerar que o comportamento humano advém de um encadeamento composto por três instâncias: a operação efetuada sobre o organismo (estímulos), o comportamento e as consequências advindas dessa interação. A primeira e a terceira instância são definidas como as variáveis externas das quais o comportamento é função, as quais possibilitam a análise funcional do comportamento (idem, ibidem). Dessa forma, o ambiente apresenta estímulos que antecedem o comportamento e esse comportamento provoca consequências que determinarão sua probabilidade de ocorrência no futuro. $\mathrm{O}$ aumento das chances de ocorrência do comportamento se dá quando há contingências reforçadoras, assim como a diminuição ocorre quando há contingências predominantemente punitivas.

Ao aplicar esse modelo de análise à relação entre pais e filhos, como proposto por Bolsoni-Silva (2003; 2008; 2009), pretende-se investigar as situações em que se dão as interações (estímulos antecedentes), as respostas comportamentais, isto é, os comportamentos emitidos pelos pais e pelos filhos, e também as consequências, ou seja, identificar as práticas parentais que reforçam ou punem comportamentos emitidos pelos filhos e vice-versa.

Tendo em vista que a relação entre pais e filhos é permeada pelo ambiente social, faz-se necessário destacar as influências dos estímulos ambientais sociais. Para Skinner (1998), o comportamento social ocorre quando duas ou mais pessoas se relacionam, mais especificamente quando interagem em um ambiente em comum que, no entanto, é afetado também por outras contingências (relações) ambientais e não somente pelas sociais. Isso quer dizer que outras situações, como, por exemplo, as condições socioeconômicas, podem afetar as interações sociais. No entanto, o foco de análise neste estudo são as interações entre pais e filhos, isto é, os comportamen- 
tos dos filhos que são contingentes aos dos pais e vice-versa, as quais podem ser denominadas contingências entrelaçadas a partir de definição de Glenn (1986).

Para a análise dessas interações sociais, devem ser consideradas as contingências que as afetam, isto é, os estímulos antecedentes aos comportamentos, que podem ser ações emitidas pelos pais ou pelos filhos, e as consequências dessas ações parentais ou filiais, as quais irão retroagir sobre as ações futuras dos pais e dos filhos. As relações presentes nesse processo são denominadas contingências entrelaçadas (Skinner, 1998), e aplicadas à interação entre pais e filhos, implicam em comportamentos emitidos por ambos e que agem como estímulo para o comportamento do outro, seja um comportamento antecedente, seja um consequente. Por exemplo, o caso de uma mãe que fala em tom agressivo com seu filho, isto é, emite um estímulo que antecede o comportamento do filho. Como resposta ao estímulo, recebe gritos. A reação de gritar do filho, que foi consequente ao comportamento materno, torna-se um estímulo antecedente ao comportamento da mãe de falar para o filho ir para o quarto ou de bater nele e assim por diante.

Esse entrelaçamento de comportamentos não é fácil de ser detectado por completo, pois nem sempre ele é discriminado pelos atores das interações sociais (idem, ibidem). No caso da interação entre pais e filhos, muitas vezes ambos podem não perceber o que controla seus comportamentos. Segundo Bolsoni-Silva (2008), em diversas situações os pais agem de forma não contingente aos comportamentos dos filhos, o que pode ser um indício de que não detectam as contingências que afetam seu comportamento na interação com os filhos.

Sobre as interações sociais, também é necessário destacar a importância dos reforçadores que, para serem considerados sociais, requerem a presença de outra pessoa (idem, ibidem). No ambiente social, os reforçadores podem variar, pois dependem das condições que afetam o agente reforçador (idem, ibidem). Na relação entre pais e filhos, pode-se dizer que tanto os pais quanto os filhos podem agir como agentes reforçadores. Por exemplo: a mãe pode reforçar um 
comportamento emitido pelo filho ao elogiá-lo; o filho pode aumentar a probabilidade de que a mãe venha a elogiá-lo novamente ao emitir esse comportamento em outro momento. Interações nas quais tanto o filho quanto a mãe agem como agentes reforçadores.

Outro aspecto relevante dos reforçadores sociais diz respeito aos fatores que afetam as mudanças das contingências reforçadoras (Andery, Micheletto \& Sério, 2005). Transpondo esse conhecimento para a relação entre pais e filhos, cita-se o exemplo da mãe que apresenta uma regra ao filho. Dependendo do comportamento deste, a mãe apresentará diferentes reações: se ele a obedecer, ela poderá reforçar a obediência com atenção social; se ele não a obedecer, ela poderá deixar de reforçar, retirando a atenção (punição negativa). Assim, será possível perceber a mudança de contingências influenciada pelos estímulos antecedentes, no caso em que o filho obedece ou não. Os estímulos antecedentes, que afetam o comportamento dos agentes reforçadores, neste caso a ação materna, não são tão fáceis de ser detectados, principalmente quando se tratam de estímulos não presentes na situação imediata (Skinner, 1998). Por exemplo, a mãe pode brigar com seu filho influenciada por uma situação que viveu em outra contingência ambiental, como no trabalho e/ou no relacionamento conjugal.

As condições que afetam os agentes reforçadores podem ser as mais variadas. O que depende do momento atual do indivíduo quando interage com o outro, depende também de sua história e de suas experiências anteriores, que são influenciadas pelo ambiente cultural. A cultura determina os padrões de comportamento de uma comunidade. Alguns desses padrões são reforçados e outros não(idem, ibidem). A prática cultural é formada a partir do comportamento social, mas é mais ampla por envolver a transmissão de comportamentos operantes de uma geração para outra (Andery, Micheletto \& Sério, 2005). Skinner (1998) afirma ser mais fácil identificar as contingências observadas no ambiente social do que explicar as razões dessas contingências culturais.

Segundo Andery, Micheletto e Sério (2005), é difícil identificar e descrever todas as contingências culturais envolvidas nas relações 
estabelecidas para o reforço dos comportamentos em dada cultura. Nesse sentido, ao estudar as relações entre pais e filhos, é mais fácil acessar as contingências entrelaçadas presentes no ambiente social, isto é, nas interações entre os pais e seus filhos e seu ambiente atual. Essas interações podem ser observadas e analisadas por meio da contingência de três termos, que permite a análise funcional dessa interação.

Dentro desse contexto, a proposta de Bolsoni-Silva (2003; 2008; 2009) pretende, por meio da identificação dos comportamentos emitidos pelos pais e pelos filhos, realizar a análise funcional das contingências entrelaçadas presentes nessa interação. Para realizar tal procedimento, a autora buscou variáveis organizadoras do comportamento social nas categorias de análise do modelo de habilidades sociais (Del Prette \& Del Prette, 1999; 2001), aplicadas às interações estabelecidas entre pais e filhos (Bolsoni-Silva, 2003).

As habilidades sociais que os pais utilizam com o intuito educativo são denominadas Habilidades Sociais Educativas Parentais (idem, ibidem) e equivalem a um conjunto de comportamentos que os pais emitem na interação com seus filhos. Essas habilidades são práticas parentais que permitem a transmissão de padrões, valores e condutas com o objetivo de possibilitar a socialização e a competência do filho em interações sociais (Bolsoni-Silva, 2003; Bolsoni-Silva \& Marturano, 2006).

Para a categorização das Habilidades Sociais Educativas Parentais, Bolsoni-Silva (2003) baseou-se na classificação das habilidades sociais de Del Prette \& Del Prette (2001), a partir da qual selecionou as habilidades de comunicação, de enfrentamento e de expressão de sentimentos.

Depois da emissão do comportamento social de pais ou filhos, haverá consequências ou efeitos sobre o ambiente que, ao serem avaliados, podem ser classificados como habilidosos ou não, a depender de sua funcionalidade e de pressupostos culturais. Bolsoni-Silva \& Carrara (no prelo) consideram importante diferenciar a funcionalidade do comportamento de sua qualificação, a qual é controlada pela cultura, uma das instâncias de seleção do comportamento hu- 
mano. Os autores destacam que o termo "habilidade social" provavelmente está relacionado ao que é considerado benéfico em um ambiente cultural. Neste sentido, as habilidades sociais remetem a uma dimensão moral que direciona determinada cultura sobre o que pode ser ensinado ou não, sobre o que deve ser reforçado ou punido. Por consequência, os comportamentos serão considerados habilidosos se produzirem mais consequências reforçadoras positivas do que negativas em determinada cultura (idem, ibidem).

Portanto, Bolsoni-Silva \& Carrara (idem) citam a relevância de se levar em consideração a funcionalidade do comportamento para poder classificá-lo como habilidoso ou não. Em outras palavras, fazse necessário considerar a relação entre as instâncias de respostas observáveis, verificando os antecedentes (estímulos discriminativos) e os consequentes (observados ou inferidos) relacionados ao comportamento. É importante, por isso, destacar os diferentes contextos de participação das pessoas, os quais irão contribuir para a aprendizagem ou não de habilidades sociais, em especial as experiências advindas da relação com os pais, que podem ou não estimular as habilidades sociais dos filhos (Bolsoni-Silva, 2003; 2008; 2009).

As Habilidades Sociais Educativas Parentais que parecem prevenir problemas de comportamento ${ }^{3}$ são compostas por categorias comportamentais amplas que envolvem a comunicação, a expressão de sentimentos, o enfrentamento e o estabelecimento de limites por parte dos pais (idem, ibidem). O repertório dos pais pode ser investigado e classificado como habilidoso quando as Habilidades Sociais Educativas Parentais citadas ocorrem com frequência e em situações adequadas para tal. Será classificado como não habilidoso quando há ausência ou pouca frequência de habilidades sociais educativas. O repertório dos filhos também pode ser avaliado e classificado como habilidoso ou não, o que depende de suas ações nas interações

3 Os problemas de comportamento podem dificultar o desenvolvimento de novas habilidades sociais infanto juvenis, porque limitam o acesso do jovem às contingências de reforço responsáveis pela aprendizagem de novas habilidades (Bolsoni-Silva \& Del Prette, 2003). 
familiares, bem como das ocasiões em que esses comportamentos são emitidos (idem, 2009).

As variáveis parentais preventivas de problemas de comportamento selecionadas por Bolsoni-Silva (2003; 2008; 2009) com crianças em idade pré-escolar ou escolar estão em congruência com as variáveis citadas por estudos sobre a interação entre pais e filhos adolescentes (Gomide, 2003; 2004; Stattin \& Kerr, 2000; Patterson, Reid \& Dishion, 1992; Dishion \& McMahon, 1998; Fletcher, Steinberg \& Williams-Wheller, 2004; Ha et al., 2009; Shelton \& Harold, 2008). Como mostra o estudo de Dishion \& McMahon (1998), no qual os autores informam que para os pais administrarem os comportamentos dos adolescentes é necessário que modelem positivamente $e^{4}$ o comportamento do jovem a partir de incentivos, elogios, feedbacks, auxílio, negociação e também de aplicação de limites. Em outras palavras, os pais devem estar atentos às consequências aplicadas aos comportamentos do filho adolescente, o que é denominado modelagem do comportamento. Além disso, as práticas parentais na interação com o filho adolescente devem ser contextualizadas, sendo necessário considerar a idade daquele, a comunidade, a estrutura familiar (pais casados, separados ou solteiros) e as condições financeiras (Gomide, 2003; 2004; Stattin \& Kerr, 2000; Patterson, Reid \& Dishion, 1992; Fletcher, Steinberg \& Williams-Wheller, 2004).

Os estudos sobre a relação entre pais e filhos adolescentes utilizam o termo "monitoria parental" como referente à forma de comunicação e ao controle por meio dos quais os pais se relacionam com seus filhos (Gomide, 2003; Dishion \& McMahon, 1998). Para que a monitoria do filho adolescente seja efetiva, os pais precisam usar estratégias de comunicação positiva, em outras palavras, tentar uti-

4 Modelar positivamente, do termo modelagem (Skinner, 1998), é a expressão usada para designar a situação em que os pais ensinam os filhos fornecendo reforçadores diferencial e gradativamente de modo contingente a mudanças desejáveis em propriedades topográficas e/ou funcionais dos repertórios dos filhos. Em outras palavras, os pais podem ensinar novos comportamentos, reforçando alguns em detrimento de outros e, aos poucos, aumentar a especificidade dos comportamentos que precisam ser reforçados. 
lizar na maior parte das interações com os adolescentes os reforçadores positivos em detrimento dos negativos (Gomide, 2003). A monitoria positiva envolve o conhecimento e a orientação das vivências do adolescente por meio de métodos não coercitivos, ${ }^{5}$ que podem funcionar como uma medida preventiva primária ou secundária na redução de comportamentos de risco (Gomide, 2003; Dishion \& McMahon, 1998).

Stattin \& Kerr (2000) afirmam que a comunicação positiva entre pais e filhos é o principal instrumento de prevenção de problemas de comportamento na adolescência, de modo que a comunicação está associada ao controle parental não coercitivo. Em função disso, os autores propõem que os pais procurem conhecer seus filhos por meio de três estratégias: revelação do filho, solicitação parental e controle parental.

A revelação do adolescente ocorre quando ele fala e conta aos pais espontaneamente sobre si (Stattin \& Kerr, 2000). Para tanto o adolescente deve ser estimulado a fazer isso a partir da audiência não punitiva, da aceitação de sua opinião e da expressão de afeto em sua família desde cedo (Gomide, 2003; 2006).

As solicitações parentais ocorrem quando os pais fazem perguntas aos filhos sobre o seu dia a dia. No entanto, é importante destacar que, caso as solicitações parentais sejam excessivas ou em momentos inadequados, poderão produzir consequências punitivas para a comunicação entre pais e filhos. E a partir do controle via comunicação os pais podem estipular regras sobre as atividades do adolescente, mostrando-lhe as consequências de seu comportamento (Stattin \& Kerr, 2000).

5 A coerção ocorre quando os comportamentos são controlados por reforço negativo ou punição (Sidman, 2001). O reforço negativo consiste em um tipo de relação comportamental em que há o aumento da frequência de um comportamento operante contingente à retirada de um estímulo consequente aversivo (Skinner, 1998). A punição consiste na diminuição ou eliminação da ocorrência de determinado comportamento quando ocorre a adição de um estímulo aversivo (punição positiva) ou quando há a retirada de um estímulo não aversivo (punição negativa) contingente à ocorrência de tal comportamento (idem, ibidem). 
Desta forma, o procedimento sugerido por Stattin \& Kerr (idem) para a comunicação entre pais e filhos adolescentes vai ao encontro da habilidade social educativa de comunicação, sugerida por BolsoniSilva (2003; 2008; 2009). Segundo tal sugestão, há a proposta de identificação das ocasiões em que os pais conversam com seus filhos chamando a atenção para os assuntos e a forma com que os filhos respondem às interações. As reações dos filhos nos momentos de comunicação são um modo para verificar se eles estão agindo de forma habilidosa, mostrando disponibilidade einteresse. Por outrolado, quando os filhos estão com problemas na comunicação com seus pais, agem de forma desinteressada, afastam-se dos pais e/ou mudam de assunto (Bolsoni-Silva \& Marturano, 2006).

A reação não habilidosa do filho, como não falar nada ou falar gritando, pode ser consequência da comunicação punitiva na interação entre pais e filhos e é considerada de risco para os problemas de comportamento no adolescente, já que ele deixa de conversar com os pais por receio de ser punido, o que aumenta as chances de envolvimento em situações de risco por falta de orientação (Gomide, 2003; Stattin \& Kerr, 2000). Esse adolescente pode vir a se aproximar de grupos considerados desviantes, pois eles funcionam como rede de apoio para ele (Patterson, Reid \& Dishion, 1992).

A comunicação punitiva pode ocorrer por ameaças verbais de punição, humilhações, hostilidade ou mesmo por intrusão parental. Esta é denominada controle psicológico do filho, abuso psicológico, coerção parental, ou, de modo geral, prática parental negativa (Pettit et al., 2001; Gomide, 1998; 2003; Sidman, 2001; Dishion \& McMahon, 1998).

A restrição do repertório comportamental do adolescente nesse tipo de interação punitiva é incentivada pelas práticas parentais coercitivas, as quais reduzem a probabilidade de reforçamento positivo ${ }^{6}$ do comportamento do jovem, diminuem a variabilidade e enfra-

6 A definição de reforçamento positivo, segundo a análise do comportamento (Skinner, 1998), é relacional, pois envolve um conjunto de comportamentos, denominados operantes, que se mantêm por suas consequências. Estas aumen- 
quecem as condutas daquele, tais como tomar decisões e analisar as consequências do próprio comportamento (Reichert \& Wagner, 2008). De acordo com Sidman (2001), as práticas parentais estritamente punitivas não são estimuladoras da ampliação do repertório comportamental do filho, o que aumenta a possibilidade de surgirem problemas de comportamento em função do déficit ${ }^{7}$ em habilidades sociais. Consequentemente, o jovem fica mais vulnerável a situações de risco tais como envolvimento com pares desviantes, isolamento social, uso de drogas, sexo desprotegido (Patterson, Reid \& Dishion, 1992).

Nesse sentido, Bolsoni-Silva (2003) propõe a comunicação voltada para temas de sexualidade. A autora considera a conversa sobre sexo um comportamento habilidoso quando os pais atentam para as dúvidas e o comportamento dos filhos. Destacando que a comunicação sobre sexualidade não está alienada aos demais temas, ela é influenciada pelo estilo familiar de comunicação em geral (Dias \& Gomes, 1999). A diversidade de temas e assuntos nas interações e a estimulação da conversa voltada para os temas de interesse do filho são estratégias que podem prevenir problemas de comportamento, sendo uma alternativa que possibilita a aprendizagem de novas habilidades ao jovem, ao invés do uso da coerção parental (Goldiamond, 2002).

Em consonância com a proposta da comunicação positiva como forma de prevenção, as conversas com o filho adolescente sobre a sexualidade o tornam mais preparado para tomar decisões em relação ao seu comportamento sexual (Silvares, 2002). O adolescente que recebe orientação tende a iniciar as atividades sexuais mais tar-

tam a probabilidade de que as mesmas condutas se repitam também no futuro a partir de estímulos de reforço que trazem uma adição ao ambiente. Em outras palavras, dizemos que houve reforço positivo a partir do aumento da frequência de um comportamento operante e da adição de um estímulo ao ambiente.

7 Os déficits comportamentais referem-se à ausência ou à baixa frequência, magnitude e intensidade de uma resposta, o que também pode ser considerado impróprio de acordo com a demanda situacional (Ross, 1979; Gelfand \& Hartman, 1975). 
diamente (Romer et al., 1994), o que provavelmente demonstra que ele teve a oportunidade de refletir e de tomar decisões baseadas em informações discutidas com os pais.

As Habilidades Sociais Educativas Parentais de expressão de sentimentos e de enfrentamento são, conforme Bolsoni-Silva (2008), uma referência aos comportamentos verbais dos cuidadores para a expressão dos sentimentos. Quando o indivíduo exprime seus sentimentos, ele o faz de modo positivo e negativo e, com o enfrentamento, ele emite opiniões e demonstra carinho. Essas ações parentais são modelos para os filhos, assim como quando os pais estão atentos e reforçam tais ações emitidas pelos filhos, podem favorecer a ocorrência de expressão de sentimentos e enfrentamento dos jovens.

A expressividade emocional honesta e contextualizada previne problemas de comportamento, pois os pais, ao expressarem seus sentimentos, possivelmente estão ensinando a seus filhos os comportamentos esperados para aquele ambiente e talvez para a sociedade em geral (Bolsoni-Silva \& Marturano, 2002). Autores da área de treinamento em habilidades sociais (Del Prette \& Del Prette, 1999) valorizam a assertividade na expressão de sentimentos. Eles destacam que o indivíduo que vive em um ambiente punidor da expressão emocional pode aprender a evitar situações emocionais, o que talvez traga dificuldades de interação. Essas dificuldades podem ser evidenciadas pelos problemas de comportamento dos filhos, os quais muitas vezes ocorrem como forma de obtenção de reforçadores na interação com os pais. Por exemplo, o fato de a atenção dos pais, ou mesmo de a esquiva de desaprovação, ser contingente à mentira do filho ao anunciar que tirou uma boa nota demonstra relações de contingência estimadas como inadequadas, nas quais - contingente à emissão de um comportamento problemático (mentira) - existem reforçadores positivos (produção da atenção desejável dos pais) e esquiva de reforçadores negativos (medidas verbais e não verbais de desaprovação). Esse problema na interação com os pais pode trazer como consequência para o desenvolvimento do adolescente déficits em habilidades sociais e acadêmicas. 
Para expressar adequadamente os sentimentos, os pais precisam discriminar quais dos comportamentos dos filhos devem ser reforçados e quais devem ser punidos. Para isso, os pais precisam identificar também os próprios sentimentos, para não punir ou reforçar o comportamento do adolescente de acordo com suas emoções (Gomide, 2004; 2006). Os pais devem, em outras palavras, expressar sentimentos contingentes às situações vivenciadas na relação com o adolescente (idem, 2004) e também refletir sobre a forma e o momento para expressar sentimentos positivos e negativos (idem, ibidem), sendo um dos pré-requisitos para tal a capacidade de autocontrole dos pais (Bolsoni-Silva, 2003; 2008).

Para que a expressão de sentimentos negativos seja uma oportunidade de aprendizagem para a família, os pais devem auxiliar o filho adolescente a realizar a autocrítica, permitindo que ele perceba as consequências do próprio comportamento e encontre formas de reparar o dano (Gomide, 2003; 2004). Os pais devem especificar o comportamento problemático, dizer o que sentiram, avaliando o contexto e sem o uso de práticas negativas (Bolsoni-Silva, 2003).

Deve-se levar em consideração que os pais podem apresentar dificuldades para discriminar as contingências em ação, seus próprios comportamentos e sentimentos. Em função disso, Bolsoni-Silva (2009) aponta que pode faltar autoconhecimento ${ }^{8}$ aos pais, o que pode levá-los a ter pouca habilidade na expressão de sentimentos positivos e negativos. Consequentemente, a reação pouco habilidosa dos filhos é mais provável quando os pais também não sabem ao certo quando e como expressar sentimentos. Daí a importância de intervir junto aos pais de forma a ajudá-los a melhorar suas interações com os filhos.

A habilidade social educativa de expressar opiniões envolve comportamentos como manifestar opinião concordante ou discordante em relação ao comportamento do filho de forma sincera, adequada

8 Para a Análise do Comportamento, o autoconhecimento ocorre quando o indivíduo discrimina suas ações e as variáveis controladoras do seu comportamento (Skinner, 1998). 
ao contexto e assertiva, isto é, respeitando a opinião da outra pessoa, mesmo que seja discordante (idem, 2008). É importante verificar de que forma os pais expressam suas opiniões e como os adolescentes reagem, isto é, se os genitores o fazem mostrando o que pensam e sentem e se os filhos reagem de forma habilidosa ou, ainda, de forma não habilidosa passiva ou não habilidosa ativa.

Quanto à qualificação das ações mencionadas, a habilidosa fundamenta-se em comportamentos que estimulam as habilidades do adolescente, tais como a de expressar sua opinião incentivada pela audiência compreensiva. A reação não habilidosa passiva, por sua vez, é a punição negativa do comportamento do filho, caracterizada por ações passivas, como, por exemplo, não demonstrar interesse pelo adolescente e ignorá-lo quando ele expressa o que pensa e sente. Já a reação não habilidosa ativa é a punição positiva do comportamento do filho, por exemplo, a crítica de forma agressiva e a não aceitação de que o filho pense de forma diferente.

O estudo de Alberti \& Emmons (2008) aponta alguns comportamentos assertivos de enfrentamento importantes para as interações sociais. Eles destacam as habilidades de exercer os próprios interesses sem desconsiderar os dos outros, o que pode ser aplicado a favor das Habilidades Sociais Educativas Parentais, como proposto por Bolsoni-Silva \& Marturano (2002) ao defenderem a assertividade na relação entre pais e filhos. Segundo as autoras, os pais precisam falar aos filhos o que pensam e sentem de forma contextualizada, ouvir respeitosamente a opinião deles e criticar somente o necessário para que a relação não se torne excessivamente punitiva. Os pais que punem excessivamente as opiniões dos filhos podem aumentar a probabilidade da supressão desse comportamento daqueles e viceversa, sendo que é um comportamento importante para resolver problemas em diferentes contextos.

Em consonância com Bolsoni-Silva \& Marturano (2002), a investigação sobre a habilidade de autonomia na adolescência mostra que jovens excessivamente punidos por seus pais passam a enfrentar as experiências de vida de forma despreparada, isto é, sem aceitar as orientações parentais e também sem discriminar o que pensam, sen- 
tem e de que forma agir (Reichert \& Wagner, 2007; Luyckx, 2007). Esse tipo de interação pode estimular o adolescente a se envolver em situações perigosas, tais como o envolvimento sexual desprotegido ou precoce e o uso de álcool e drogas (Borawski, 2003). Considerando esses fatores, o comportamento dos pais de estimular a expressão de opiniões dos filhos de forma habilidosa pode ser considerado uma forma de prevenção de comportamentos de risco na adolescência (Luyckx et al., 2007; Reichert \& Wagner, 2007; Pacheco, Silveira \& Schneider, 2008).

A demonstração de carinho, habilidade social educativa parental que faz parte da categoria expressão de sentimentos e enfrentamento, consiste na emissão de comportamentos verbais e/ou gestuais de agrado aos filhos. Entre esses comportamentos estão beijar, abraçar, elogiar e ajudar o filho na resolução de problemas (Bolsoni-Silva, 2009).

A expressão de afeto vem sendo caracterizada pelas mais diversas pesquisas (Gomide, 2003; 2004; Otta, 1994) como variável preventiva dos problemas de comportamento entre pais e filhos adolescentes, já que transmite ao filho a sensação de ser amado e aceito, inibindo problemas como a agressividade, a insegurança e a vulnerabilidade e aumentando as chances de o jovem se comportar de forma mais amistosa nas interações com os pais. Os jovens que se sentem amados depositarão maior confiança em seus pais e, consequentemente, será mais fácil para estes dar aos filhos a devida orientação e para estes, aceitá-las (Stattin \& Kerr, 2000). Por isso, a demonstração de carinho permite relações familiares agradáveis, em outras palavras, mais reforçadoras positivas do que negativas. Já a falta de afeto está associada a problemas de comportamento e pode ser caracterizada como negligência (Gomide, 2003; Weber et al., 2002).

Outro aspecto inibidor de problemas de comportamento éa Habilidade Social Educativa Parental de estabelecimento de limites (Bolsoni-Silva, 2008), a qual está relacionada ao comportamento de os pais identificarem as razões pelas quais se estabelecem limites, os comportamentos que consideram apropriados e inapropriados aos filhos, cumprir promessas, conversar com o cônjuge para estabele- 
cer uma concordância nas práticas educativas, identificar os próprios "erros" e identificar ocasiões e comportamentos que justificam a aplicação de limites.

O estabelecimento de regras como fundamental para o desenvolvimento saudável do filho adolescente é apoiado pela literatura (Dishion \& McMahon, 1998; Gomide, 2003; 2006). Todo agente educativo tem a responsabilidade de guiar, corrigir e socializar seu educando a partir de comportamentos apropriados. Essas ações dos adultos são denominadas orientação e disciplina (Barakat \& Clark, 2001). Bolsoni-Silva (2003; 2008) e os autores citados apontam para a importância do reforço positivo contingente aos comportamentos pró-sociais ${ }^{9}$ e da punição comedida contingente aos comportamentos problemáticos. É necessário, no entanto, manter a consistência na aplicação de consequências para o cumprimento ou descumprimento de regras anteriormente estabelecidas (Gomide, 2003).

O estudo de Fletcher, Steinberg \& Williams-Wheller (2004) vai ao encontro da proposta de Bolsoni-Silva $(2003 ; 2008)$ ao mostrar que adolescentes são menos propensos ao uso de substâncias quando seus pais, além de calorosos e envolvidos em suas vidas, provemse de níveis adequados de controle sobre as atividades do adolescente. Mais especificamente, os pais que se comunicam com seus filhos, os monitoram, estabelecem regras e as cumprem apresentam maior conhecimento e controle sobre o comportamento deles.

O comportamento de cumprir promessas, item que faz parte da categoria estabelecimento de limites (Bolsoni-Silva, 2008), faz com que os filhos confiem em seus pais. Ao prometer e não cumprir, além de decepcionar os jovens agindo de uma forma inconsistente, os pais podem estar ensinando os filhos a agir da mesma forma e também a não confiar neles (idem, 2000).

9 Os comportamentos pró-sociais são favoráveis ao convívio do indivíduo em sociedade, são considerados habilidades sociais por aumentarem as chances de obtenção de reforçadores no ambiente social. Podem ser exemplificados por ações tais como a cooperação, a disponibilidade, a comunicação assertiva e a polidez. 
Em consonância com Bolsoni-Silva (2008), Gomide (2004) afirma que os pais, quando estabelecem acordos e não cumprem, podem dar margem à aprendizagem de problemas de comportamentos. Os filhos, nesses casos, podem não se engajar em suas atividades e responsabilidades, inventar mentiras e apresentar reações desafiadoras e opositoras. Há oportunidades também para o surgimento de comportamentos reativos, como os sentimentos de raiva, tristeza e decepção em relação aos pais. Estes agem como modelo de comportamento para os filhos e quando envolvidos em comportamentos desviantes, ${ }^{10}$ podem influenciar seus filhos a ter comportamentos semelhantes (Marinho, 2001; 2003).

A categoria estabelecimento de limites também envolve o comportamento dos pais na identificação de seus próprios erros na relação com os filhos (Bolsoni-Silva, 2003; 2008; 2009). Nas relações humanas em geral, admitir erros e pedir desculpas não são comportamentos fáceis de serem praticados, pois provocam diminuição, mesmo que momentânea, da autoestima. São, por isso, considerados como uma habilidade social de enfrentamento com a qual se permite diminuir ressentimentos e superar as divergências (Del Prette \& Del Prette, 2001).

A habilidade dos pais de pedir desculpas é considerada essencial na aprendizagem desse comportamento do filho e é realizada por modelação e modelagem (Bolsoni-Silva, 2003). Apesar da importância dessa habilidade, Silva (2000) diagnosticou que os pais têm receio de admitir seus erros diante dos filhos e de ensiná-los a pedir desculpas, de modo que acabam utilizando meios punitivos. Os pais têm receio de que ao pedirem desculpas estejam se desvalorizando em relação aos filhos. É certo que tal afirmativa tem relação com regras estabelecidas nas práticas culturais que passam de geração a geração.

A habilidade social educativa parental de entendimento do casal também é essencial para estabelecer limites consistentes. Os pais podem concordar ou não com as convicções que consideram essen-

10 Os comportamentos desviantes são aqueles que podem trazer prejuízos de ordem social para o indivíduo e para as pessoas que convivem com ele. 
ciais na formação do filho, mas podem também discordar e conversar sobre o tema na ausência ou na presença daquele (Silva, 2000). O entendimento conjugal previne os problemas de comportamento do filho quando os pais apresentam valores semelhantes sobre como educar um filho e quando conversam sobre as diferenças na ausência deste. É importante lembrar que ambos devem sempre respeitar a opinião e a autoridade do cônjuge perante o filho (Bolsoni-Silva, 2003; 2009). Nesse caso, os comportamentos de comunicação e afeto podem ser generalizados para as interações conjugais de forma a garantir a consistência imprescindível para o estabelecimento de limites ao comportamento dos filhos.

Em concordância com a proposta de Bolsoni-Silva (2003; 2008; 2009), outros estudos demonstram que as divergências de opiniões parentais sobre os comportamentos adequados e inadequados em relação à educação do filho podem confundir o adolescente sobre como ele deve se comportar. Para Ha et al. (2009), quando os pais concordam quanto aos comportamentos que consideram adequados aos filhos, é mais fácil obter a coerência na educação do adolescente. A mensagem transmitida a ele é mais clara e consistente; logo, os pais não precisam utilizar de coerção para controlar o comportamento do jovem, prática parental que está associada à depressão na adolescência. Outro estudo aponta para o fato de as relações conflituosas entre o casal estarem associadas aos problemas de comportamento dos adolescentes, devido à hostilidade presente nas brigas ser transmitida ao jovem (Shelton \& Harold, 2008).

\section{Conclusão}

Como apresentado, nas mais diversas interações as ações parentais irão exercer influência sobre os comportamentos dos filhos, os quais irão agir na interação com os pais e também modificar as práticas parentais, aspectos da interação os quais são congruentes com as contingências entrelaçadas (Skinner, 1998). Este estudo mencionou pesquisas sobre a relação entre pais e filhos adolescentes que 
admitem interpretações sob o enfoque da Análise do Comportamento (Bolsoni-Silva, 2003; 2008; 2009). Esse processo foi realizado por meio da busca de pesquisas atuais sobre a relação entre pais e filhos adolescentes (Gomide, 2003; 2004; Stattin \& Kerr, 2000; Fletcher, Steinberg \& Williams-Wheller, 2004; Ha et al., 2009; Shelton \& Harold, 2008) analisadas sob a ótica analítico-comportamental (Skinner, 1998).

Destaca-se que a análise das relações funcionais entre os pais e seus filhos adolescentes e a detecção das contingências entrelaçadas presentes nessas interações podem ser úteis para estudos sobre a avaliação dos comportamentos dos pais e dos filhos, assim como podem facilitar o planejamento de estudos de intervenção voltados para os pais e para os adolescentes.

\section{Referências bibliográficas}

ALBERTI, R. E; EMMONS, M. Como se tornar mais confiante e assertivo: aprenda a defender suas ideias com tranquilidade e segurança. Rio de Janeiro: Sextante, 1970/2008.

ANDERY, M. A. P. A.; MICHELETTO, N.; SÉRIO, T. M. A. P. A análise de fenômenos sociais: esboçando uma proposta para a identificação de contingências entrelaçadas e metacontingências. Revista Brasileira de análise do comportamento, v.1, n.2, p.149-64, 2005.

BARAKAT, I. S.; CLARK, J. A. Positive discipline and child guidance. Human development and family studies, February 1, 2001.

BOLSONI-SILVA, A. T.; MARTURANO, E. M. Práticas educativas e problemas de comportamento: uma análise à luz das habilidades sociais. Estudos de Psicologia, v7 n.2, p.227-35, 2002.

Habilidades sociais educativas, variáveis contextuais e problemas de comportamento: comparando pais e mães de pré-escolares. Tese (Doutorado). Faculdade de Filosofia, Ciências e Letras de Ribeirão Preto, USP, Ribeirão Preto, 2003.

; DEL PRETTE, A. Problemas de comportamento: um panorama da área. Revista Brasileira de terapia comportamental e cognitiva, n.2, p.91-103, 2003 
; MARTURANO, E. M. A qualidade da interação "pais e filhos" e sua relação com problemas de comportamentos de pré-escolares. In: BANDEIRA, M.; DEL PRETTE, Z. A. P.; DEL PRETTE, A. (Orgs.) Estudos sobre habilidades sociais e relacionamento interpessoal. São Paulo: Casa do Psicólogo, 2006.

Roteiro de entrevista de habilidades sociais educativas parentais (RE-HSE-P): categorias e testagens preliminares. IN:WEBER, L. N. D. (Org.) Família e desenvolvimento humano. Curitiba: Juruá, 2008, p.145-58.

Estudos de validação e confiabilidade do roteiro de entrevista de habilidades sociais educativas parentais (RE-HSE-P). Tese (Pós-doutorado). Faculdade de Filosofia, Ciências e Letras de Ribeirão Preto, USP, Ribeirão Preto, 2009.

; CARRARA, K. Habilidades sociais e análise do comportamento: compatibilidades e dissensões conceitual-metodológicas. No prelo BORAWSKI, E. A. et al. Parental monitoring, negotiated unsupervised time, and parental trust: the role of perceived parenting practices in adolescent health risk behaviors. Journal of adolescent health, n.33, p60-70, 2003.

CARVALHO NETO, M. B. Análise do comportamento: behaviorismo radical, análise experimental do comportamento e análise aplicada do comportamento. Interação em Psicologia, v.6 n.1, p.13-8, 2002.

DEL PRETE, A; DEL PRETE, Z. A. P. Psicologia das habilidades sociais: terapia e educação. Petrópolis: Editora Vozes, 1999.

; _ Psicologia das relações interpessoais: vivências para o trabalho em grupo. Petrópolis:Vozes, 2001.

DIAS, A. C. G.; GOMES, W. Conversas sobre sexualidade na família e gravidez na adolescência: a percepção dos pais. Estudos de Psicologia, v.4, n.1, p.79-106, 1999.

DISHION, T. J.; McMAHON, R. J. Parental monitoring and the prevention of child and adolescent problem behavior: a conceptual and empirical formulation. Clinical child and family psychology review, v.1, n.1, 1998.

FLETCHER, A. C.; STEINBERG, L.; WILLIAMS-WHELER, M.. Parental influences on adolescent problem behavior: revisiting Stattin and Kerr. Child development, v.75, n.3, p.781-96, may-jun., 2004.

GELFAND, D. M.; HARTMAN, D. P. Child behavior analysis and therapy. USA: Pergamon General Psychology Series, 1975. 
GLENN, S. S. Metacontingencies in Walden Two. Behavior analysis and social action, v.5, p.2-8, 1986.

GOLDIAMOND, I. Toward a constructional approach social problems: ethical and constitutional issues raised by applied behavior analysis. Behavior and social issues, v.11, p.108-97, 2002.

GOMIDE, P. I. C. Estilos parentais e comportamento antissocial. In: DEL PRETTE, A.; DEL PRETTE, Z. A. P. (Orgs.). Habilidades sociais, desenvolvimento e aprendizagem: questões conceituais, avaliação e intervenção. Campinas: Alínea, 2003, p.21-60.

Pais presentes, pais ausentes. Vozes: Petrópolis, 2004.

Manual do inventário de estilos parentais: modelo teórico, manual de aplicação, apuração e interpretação. Vozes: Petrópolis, 2006.

HA, T. et al. Marital quality, parenting, and adolescent internalizing problems: a three-wave longitudinal study. Journal of family psychology, v.23, n.2, p.263-7, 2009.

LUYCKX, K. et al. Parental psychological control and dimensions of identity formation in emerging adulthood. Journal of family psychology, v.21, n.3, p.546-50, 2007.

MARINHO, M. L. Subsídios ao terapeuta para análise e tratamento de problemas de comportamento em crianças: quebrando mitos. In: MARINHO, M. L.; CABALLO, V. E. (Orgs.). Psicologia clínica e saúde. Londrina: UEL; Londrina; Granada: UEL, APICSA: APICSA, 2001.

Comportamento antissocial infantil: questões teóricas e de pesquisa. In: DEL PRETTE, A.; DEL PRETTE, Z. A. P. (Orgs.). Habilidades sociais, desenvolvimento e aprendizagem: questões conceituais, avaliação e intervenção. Campinas: Alínea, 2003, p.61-82.

OTTA, E. O sorriso e seus significados. Petrópolis: Vozes, 1994.

PACHECO, J. T. B.; SILVEIRA, L. M. O. B.; SCHNEIDER, A. M. A. Estilos e práticas educativas parentais: análise da relação desses construtos sob a perspectiva do adolescente. Psico Porto Alegre PUCRS, v.39, n.1, p.66-73, jan.-mar., 2008.

PATTERSON, G.; REID, J.; DISHION, T. Antisocial boys. OR (USA): Castalia Publishing Company, 1992.

PETTIT, G. S. et al. Antecedents and behavior: problem outcomes of parental monitoring and psychological control in early adolescence. Child Development. v.72, n.2, p.583-98, mar.-apr. 2001. 
REICHERT, C. B.; WAGNER, A. Autonomia na adolescência e sua relação com os estilos parentais. Psico Porto Alegre PUCRS, v.38, n.3, p.292-9, set.-dez 2007.

ROMER, D.; BLACK, M.; RICARDO, I. Social influences on the sexual behavior of youth at risk for HIV exposure. Journal Public Health, n.84, p.977-85, 1994.

ROSALES-RUIZ, J.; BAER, D. M. Behavioral cusps: a developmental and pragmatic concept for behavior analysis. Journal of Applied Behavior Analysis, n.30, p.533-44,1997.

ROSS, A. O. Distúrbios psicológicos na infância: uma abordagem comportamental a teoria, pesquisa e terapêutica. Tradução de Auriphebo Berrance Simões. São Paulo: McGraw-Hill do Brasil, 1979.

SABBAG, G. M. Análise das práticas e das habilidades sociais educativas maternas na interação com os filhos adolescentes. Dissertação (Mestrado). Psicologia do Desenvolvimento e Aprendizagem. Universidade Estadual Paulista, Bauru, 2010.

SHELTON, K.; HAROLD, G. T. Interparental conflict, negative parenting, and children's adjustment: bridging links between parent's depression and children's psychological distress. Journal of family psychology, v.22, n.5, p.712-24, 2008.

SIDMAN, M. Coerção e suas implicações. Tradução de Maria Amália Andery e Tereza Maria Sério. Campinas: Livro Pleno, 2001.

SILVA, A. T. B. Problemas de comportamento e comportamentos socialmente adequados: sua relação com as habilidades sociais educativas de pais. Dissertação (Mestrado). Universidade Federal de São Carlos, 2000.

SILVARES, E. F. M. Orientação sexual da criança. In: BRANDÃO, Z.; CONTE, F. C. S.; MEZZAROBA, S. M. B. (Orgs.). Comportamento humano: tudo (ou quase tudo) que você gostaria de saber para viver melhor. Santo André: Esetec, 2002.

SKINNER, B.F. Ciência e comportamento humano. 10.ed. São Paulo: Martins Fontes, 1953/1998.

Sobre o behaviorismo. 8.ed. São Paulo: Cultrix, 1974/2003 Seleção por consequências. Tradução de Cançado, C. R. X.; Soares, P. G.; Cirino, S. Revista Brasileira de Terapia Comportamental e Cognitiva, v.9, n.1, p.129-37, 1981/2007.

STATTIN, H.; KERR, M. Parental monitoring: a reinterpretation. Child Development, v.71, n.4, p.1072-85, 2000. 
WEBER, L. N. D.; SALVADOR, A. P.V.; BRANDENBURG, O. J.; ZOCCHE, C. R. E. Famílias que maltratam: uma tentativa de socialização pela violência. PsicoUS., v.7, n.2, p.163-73, jul.-dez. 2002. 
SOBRE O LIVRO

Formato: $14 \times 21 \mathrm{~cm}$

Mancha: $23,7 \times 42,5$ paicas

Tipologia: Horley Old Style 10,5/14

1̄a edição: 2010

EQUIPE DE REALIZAÇÃO

Coordenação Geral

Marcos Keith Takahashi 


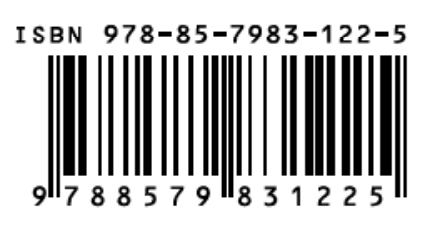

CULTURA

$\frac{\text { ACADÊMICA }}{\varepsilon d i t o r a}$ 